\title{
Molecular Characterization of the Male Germ Cell Expressed Genes Hook1 and TSEP22
}

\author{
Dissertation \\ zur Erlangung des Doktorgrades \\ der Mathematisch-Naturwissenschaftlichen Fakultäten \\ der Georg-August-Universität zu Göttingen
}

vorgelegt von

Irene Mendoza-Lujambio

Aus Guadalajara, Mexiko

Göttingen 2003 
D 7

Referent: Prof. Dr. W. Engel

Korreferentin: Prof. Dr. S. Hoyer-Fender

Tag der mündlichen Prüfung: 
To my children Frida Kathrin and Sven Alexander To my parents Luis and Aurora To my husband Juan Carlos 


\section{INDEX}

INDEX

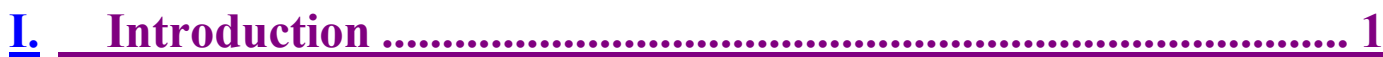

1.1. SPERMATOGENESIS IN MAMMALS ............................... 1

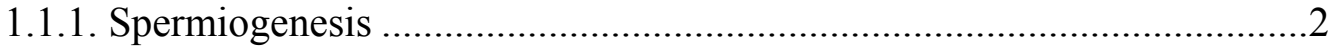

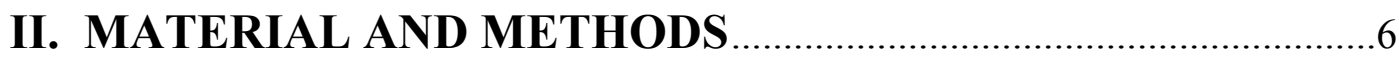

2.1. Solutions, Chemicals and Laboratory Material.................................................6

2.1.1. Solutions and Buffers .....................................................................

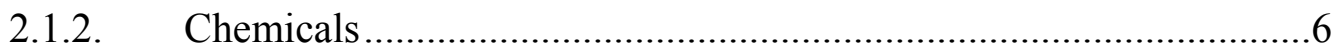

2.1.3. Laboratory Material ...................................................................

2.2. Culture Mediums for Bacteria and Mammalian Cells ....................................10

2.2.1. Bacteria Culture Medium ..................................................................10

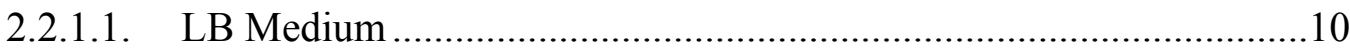

2.2.2. Mammalian Cells Culture Media …………………………………....10

2.2.2.1. 3T3 Cells Medium............................................................................

2.2.3. Sterilization Procedure .....................................................................

2.3. Biological Material................................................................................................11

2.3.1. Bacterial Strains ............................................................................

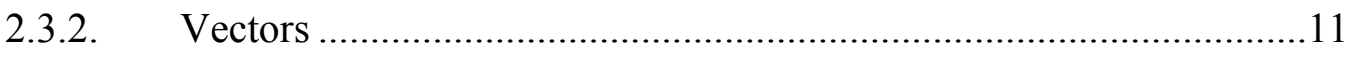

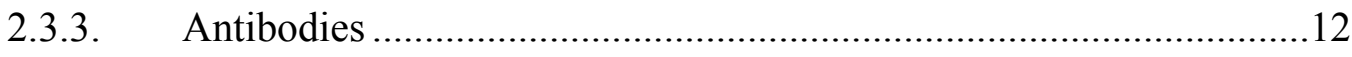

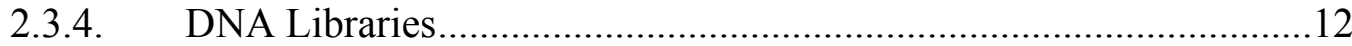

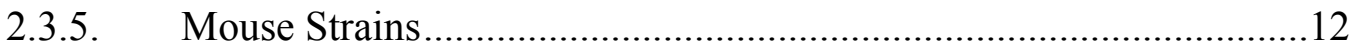

2.3.6. Mammalian cells ...........................................................................13

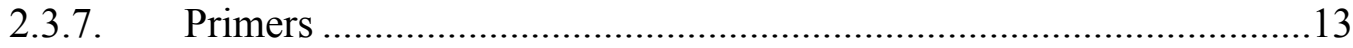

2.4. Preparation of Nucleic Acids ...............................................................................15

2.4.1. Mini-Preparation of Plasmid DNA ……………............................15

2.4.2. Standard Mini-Preparation of Plasmid DNA ........................................15

2.4.3. Midi-Preparation of Plasmid DNA using Columns ..............................16 
2.4.4. In vivo Excision of Phagemids .........................................................16

2.4.5. Isolation of Total RNA..................................................................

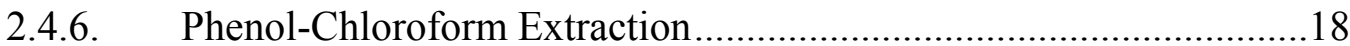

2.4.7. Ethanol Precipitation of Nucleic Acids ..............................................18

2.5. Enzymatic Modification of DNA ........................................................................18

2.5.1. Dephosphorylation of DNA 5' Ends ...............................................18

2.5.2. Cloning of DNA Fragments ..............................................................19

2.5.3. Cloning of PCR Fragments ...........................................................19

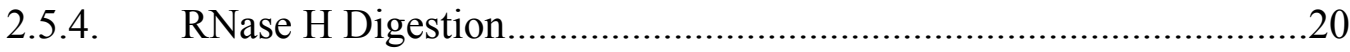

2.6. Isolation of DNA Fragments from Agarose Gels ............................................20

2.7. E. coli Competent Cells............................................................................................21

2.7.1. Production of E. coli Competent Cells...............................................21

2.7.2. Transformation of Competent Bacterial Cells ...................................21

2.8. Polymerase Chain Reaction (PCR) .................................................................22

2.8.1. PCR for amplification of DNA fragments ..........................................22

2.8.2. Reverse Transcription PCR (RT-PCR) ..............................................23

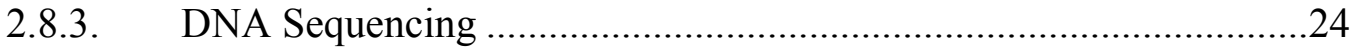

2.9. Gel Electrophoresis for Separation of Nucleic Acids.......................................24

2.9.1. DNA Horizontal Electrophoresis in Agarose Gels .............................24

2.9.2. DNA Vertical Electrophoresis in Agarose Gels..................................25

2.9.3. RNA Electrophoresis in Denaturing Agarose Gels.............................25

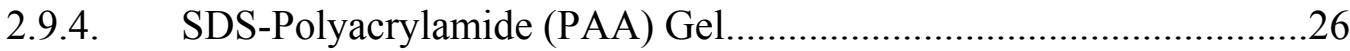

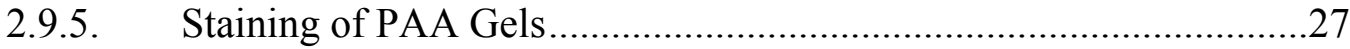

2.10. Blotting Techniques .............................................................................................28

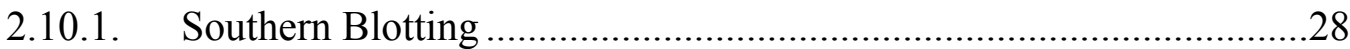

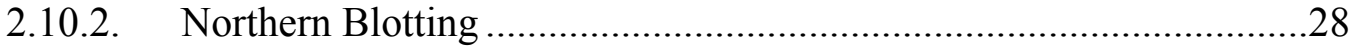

2.10.3. Colony Transfer and Hybridisation....................................................29

2.11. Labeling of Nucleic Acids...............................................................................29

2.11.1. Radioactive Labeling of Nucleic Acids ...........................................29

2.11.2. Digoxygenin labelling ......................................................................30

2.11.3. in vitro Transcription ...................................................................30 
2.12. Hybridisation Methods

2.12.1. Hybridisation of 32P-Labeled DNA with Northern or Southern Membranes .31

2.12.2. Screening of Mouse Filter Libraries .............................................31

2.12.3. Hybridisation of DIG-labeled DNA Probes ....................................32

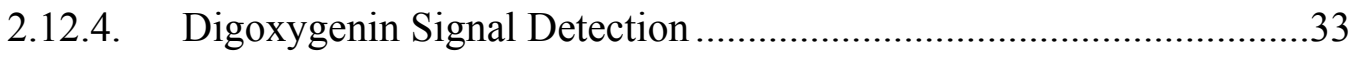

2.13. In situ Hybridisation Techniques ................................................................34

2.13.1. Pre-treatment of the Glass Slides ..................................................34

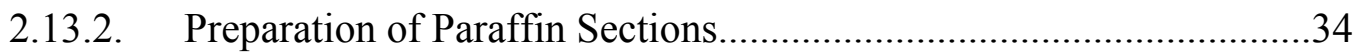

2.13.3. in situ Hybridisation of Tissue Sections .........................................35

2.13.4. Detection of DIG RNA Probes in situ ...............................................36

2.14. Protein and Immunohistochemical Methods..............................................36

2.14.1. Isolation of Total Protein from Mouse Tissue..................................36

2.14.2. Coupling of the Synthetic Peptide to BSA ..........................................

2.14.3. Isolation of Polyclonal Monospecific Antibodies.............................37

2.14.4. Production of a Strep-Tag Fusion Protein ........................................38

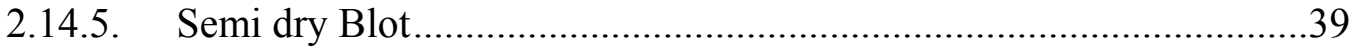

2.14.6. Streptavidin Detection of the Fusion Protein via Western Blot.........39

2.14.7. Purification of Monospecific Antibodies .......................................40

2.14.8. Western Blot Immune Detection ..................................................40

\subsection{Fluorescence in situ Hybridisation (FISH) for the Determination of}

Chromosomal Localisation ...............................................................................42

2.15.1. Nick translation (preparation of the FISH probe) ...........................42

2.15.2. Pre-handling of the Chromosome Preparations ................................43

2.15.3. Denaturation of the Chromosome Preparation and Pre-hybridisation43

2.15.4. Denaturation of the DNA Probe and Hybridisation .........................43

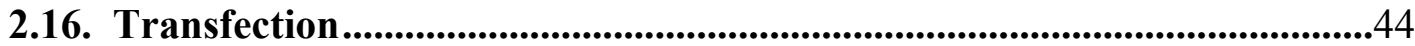

2.16.1. Generation of a Green Fluorescent Fusion Protein (GFP) ................45

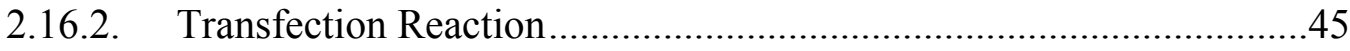

2.17. Acrosome Reaction ..................................................................................................46

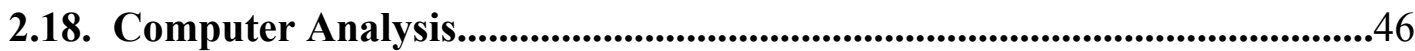


3.1. Introduction ..............................................................................................................4

3.2. Isolation and Characterization of the cDNA of the Mouse Hook1 .............48

3.2.1. Identification of the murine Hook1 cDNA ...................................48

3.2.1.1. Mouse Hook1 cDNA..................................................................49

3.2.2. Isolation of the Complete Hook1 cDNA......................................49

3.2.3. Nucleotide Sequence of the Complete cDNAs ...............................50

3.2.3.1. Nucleotide Sequence of the Mouse Hook1 cDNA ….......................50

3.2.4. Expression Analysis of the Mouse Hook1 Gene...............................52

3.2.4.1. Northern Blot Analysis of the Hook1 Gene in Mouse Tissues..........52

3.2.4.2. Northern Blot Analysis of the Hook1 Gene in Testis of Mutant Mice

3.2.4.3. Northern Blot Analyses of the Hook1 Gene in Testis during Development 54

3.2.4.4. Hook1 RTPCR Analysis with RNA from Adult Tissue and Embryonic

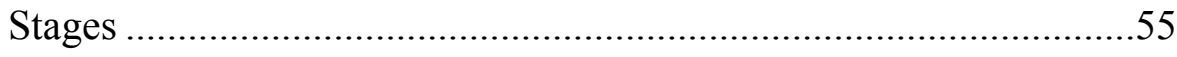

3.2.4.5. Hook1 in situ Hybridisation in Testis ..............................................57

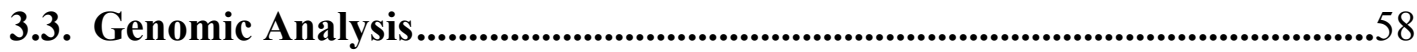

3.3.1. Isolation of Cosmid Clones with Mouse Genomic DNA...................58

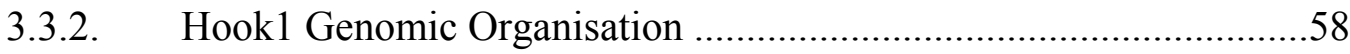

3.3.3. Southern Blot Analysis and Copy Gene Determination ...................60

3.3.4. Hook1 Chromosomal Localisation ..............................................61

3.4. Hook1 Protein Analysis ...............................................................................66

3.4.1. Sequence Analysis of the Hook1 Protein......................................62

3.4.2. Production of a Hook1-Strep-tag Fusion Protein.............................63

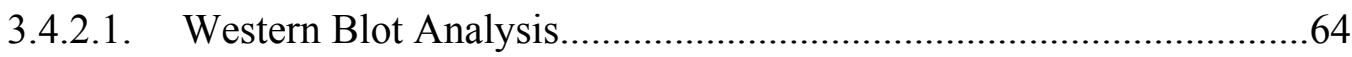

3.4.2.2. Immunohistological Analysis of Hook1 with Testis Sections ...........65

3.4.2.3. Immunocytological Analysis of Hook1 with Spermatozoa ...............66

3.4.3. Generation of a Hook1-GFP Fusion Protein ...................................66

3.5. Analysis of the azh/azh Mouse ..........................................................................66

3.5.1. Spermatozoa of the azh/azh Mouse.............................................69 
3.5.2. Testicular Histopathology of azh/azh Mouse .69

3.5.3. Acrosome Reaction with Wild Type and azh/azh Mice Spermatozoa

3.5.4. Expression Analysis of the Mouse Hook1 gene in the azh/azh

Mouse. .71

3.5.4.1. Northern Blot Analysis with RNA from the mutant mouse $\mathrm{azh} / \mathrm{azh}$ .71

3.5.4.2. RTPCR of the Hook1 Gene in the azh/azh Mouse .........................73

3.5.5. Genomic PCR of the Hook1 gene in the azh/azh Mouse...................75

3.6. Isolation and Characterization of the cDNA of the TSEP22 Gene ............78

3.6.1. Identification of the murine TSEP22 cDNA .................................78

3.6.1.1. Nucleotide Sequence of the Mouse TSEP22 ..................................78

3.6.2. Analysis of the Expression of the Mouse TSEP22 Gene..................78

3.6.2.1. Northern blot Analysis of TSEP22 ............................................78

3.6.2.2. TSEP22 In situ Hybridisation in Testis...........................................82

3.6.3. Isolation of Transcripts Homolog to the TSEP22 cDNA..................83

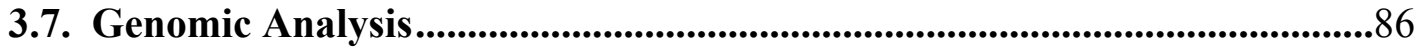

3.7.1. Isolation of Mouse Genomic Cosmid Clones .................................86

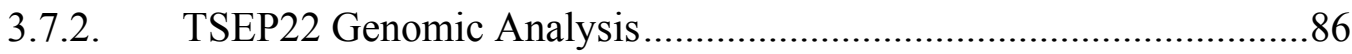

3.7.2.1. Analysis of the TSEP22 Cosmid Clones..........................................86

3.7.2.2. Southern blot Analysis and Copy Gene Determination .....................88

3.7.2.3. TSEP22 Chromosomal Localisation .............................................89

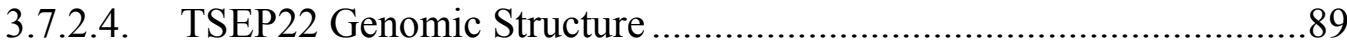

3.8. Protein Analysis ...........................................................................................90

3.8.1. Sequence Analysis of the TSEP22 Protein ....................................90

3.8.2. Generation of a TSEP22-Strep-tag Fusion Protein ..........................91

3.8.2.1. TSEP22 Western Blot .................................................................92

3.8.3. Immunohistochemical Analysis of TSEP22 in Testis Sections .........92

3.8.4. Immunocytochemical Analysis of TSEP22 in Mouse Spermatozoa .93

3.8.5. Generation of a TSEP22-GFP Fusion Protein ...............................94 
IV. DISCUSSION …................................................................................................99

4.1. Hook1 Gene ...........................................................................................................99

4.1.1. The Murine Hook1 is a Member of the Hook Gene Family ...............100

4.1.2. Expression Analysis of the Mouse Hook1 Gene..................................100

4.1.3. Genomic Organization of the Hook1 Gene..........................................104

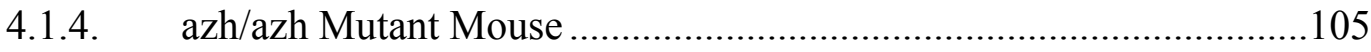

4.1.5. Expression Analysis of the Hook1 Gene in the azh/azh Mutant........108

4.1.6. Genomic Analysis of the Hook1 Gene in the azh/azh Mutant...........109

4.2. TSEP22 Gene....................................................................................................113

4.2.1. TSEP22 constitutes a Novel Testis-Specific Gene .............................113

4.2.2. Expression Analysis of the TSEP22 Gene ........................................113

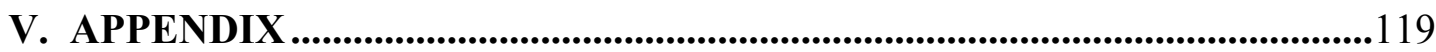

5.1. TSEP cDNA clones Nucleotide Sequences........................................................119

5.1.1. TSEP22 cDNA Sequence................................................................119

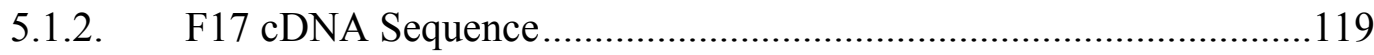

5.1.3. G101 cDNA Sequence ..................................................................119

5.1.4. P021 cDNA Sequence..................................................................119

5.1.5. O07 cDNA Sequence ......................................................................120

VI: SUMMARY ….................................................................................................... 121

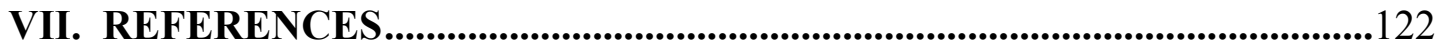

VIII. CURRICULUM VITAE ....................................................................135

IX. ACKNOWLEDGEMENTS _............................................................................136 


\section{Introduction}

\section{INTRODUCTION}

Infertility is a disease or condition of the reproductive system resulting in the inability to conceive after one year of unprotected well-timed intercourse. In the USA, one in every six couples of childbearing age has a problem conceiving. From this, a female problem counts for $35 \%$ of the cases, a male problem in $35 \%$ of the cases, a combined problem of the couple in $20 \%$ of cases, and unexplained in $10 \%$ of cases. In Germany, around 10$15 \%$ of the couples are infertile, from which, in almost the half the infertility is due to a male problem. Though, no cause for the fertility disorder is found in approximately $30 \%$ of the infertile men (idiopathic infertility) (reviewed in Neesen, 1997).

The causes of infertility are known in a small proportion of patients, and only a few are treatable. Some infertility causes are: gonadotropin deficiency, genital tract obstruction, disruption of the egg-sperm interaction, coital dysfunction and reversible effects of toxins, drugs or intercurrent illnesses, infections during childhood, sperm autoimmunity (Baker, 2000), sperm abnormalities that reduce fertility potential by causing implantation disorders (Check, 2001). In the case of the "Immotile Cilia Syndrome" (ICS), the patients present infertility and anomalies of ciliated tissues because of molecular defects in dynein genes. Also, certain mutations in the CFTR gene are associated with infertility. Other patients have reduced sperm quality or function that may be associated with previous testicular damage, varicocele or non-specific genital tract inflammation. The pathogenetic mechanisms of the most common forms of defective sperm production are unknown, which prevents the logical development of effective treatment (Baker, 2000). When a genetic defect is involved with infertility, the genes responsible for this disturbance are thought to be relevant in spermatogenesis.

\subsection{Spermatogenesis in Mammals.}

The spermatozoa due to their motility and genetic content are responsible of fertilizing the oocytes, generating new individuals. Spermatogenesis is a complex developmental process involving the mitotic amplification of germinal stem cells (spermatogonia), their differentiation into spermatocytes, meiotic division and finally the differentiation of the spermatids into mature spermatozoa. 
The spermatogenesis can be divided into three distinct phases: 1) the proliferation phase, which is characterized by many mitotic cell divisions of the spermatogonia; 2) the meiotic phase, where the genetic material of spermatocytes is recombined and divided into two and 3) the spermiogenesis, in which the mature spermatozoon is generated from the haploid spermatids (Russell, 1990). Despite the large number of testis-specific genes that have been described, the process of differentiation both before and after meiosis is very poorly understood.

\subsubsection{Spermiogenesis.}

The process of differentiation of the round haploid spermatid to the spermatozoon occurs during spermiogenesis, an interval of about 14 days in the mouse that is subdivided into Golgi, cap, acrosome and maturation phases, comprising 16 steps. Around step 8 of spermiogenesis, the round spermatid undergoes a series of shape changes ultimately producing the species-specific shaped spermatozoon. During spermiogenesis, an acrosome with enzymatic components develops over the nucleus. The chromatin proteins are replaced by protamines producing a tightly compacted DNA-protamine complex. (Clermont, 1952; Oakberg, 1956). The cellular reshaping that takes place during spermiogenesis requires a major reorganization of the gamete including a substantial reduction in mitochondrial number.

The primary components of typical sperm are the acrosome, nucleus and flagellum. The apical segment of the acrosome extends past the tip of the nucleus. It often assumes a species-specific shape. In human, it is small and inconspicuous. The acrosome contains hydrolytic enzymes, which are released from the sperm during the acrosome reaction. This occurs in the immediate vicinity of the egg and causes the sperm plasma membrane and the outer acrosomal membrane to vesiculate and be shed, thus releasing the enzymes.

The manner in which the spermatid head is shaped during spermiogenesis is one of the major unsolved problems in the process of spermatogenesis. Species variations with respect to sperm head shape are great (Bacetti, 1970; Fawcett et al. 1971). Although only a few general categories are used to classify head shape (i.e. helical, spatulate, fusiform, ovoid, globular and falciform), there are many subtle variations encountered in any one of 


\section{Introduction}

these major categories. The mechanism responsible for the elongation of the sperm head is not understood. Even though, a few theories are available to explain how the sperm nucleus, which forms the underlying structure of the sperm head, is shaped during spermiogenesis. There is circumstantial evidence indicating that the manchette, a transient microtubular component surrounding the elongating nucleus, has a role in the nuclear elongation process (Russell, 1991, Meistrich, 1993).

The rat manchette, consisting of a perinuclear mantle of microtubules radiating from a dense perinuclear ring (Zlotnik, 1943; Fawcett et al., 1971; Rattner and Brinkley, 1972), starts its development during step 8 of spermiogenesis (the acrosomal phase) and ends by step 14, when its perinuclear contact is reduced to a minimum and its length reaches a maximum (Clermont et al., 1993). The microtubular manchette differs from single cytoplasmic microtubules in its specific perinuclear position, its structural stability for about 2 weeks, and the moment of its appearance, since it starts to assemble when the tubulin-containing axoneme is already present. The wall of the manchette, which reaches its maximal size during step 14 , is composed of numerous microtubules running parallel to each other and linked by lateral fine filamentous bridges (MacKinnon et al., 1973). The $\alpha \beta$ tubulin dimer is the structural unit of microtubules of the manchette. Also, microtubule-associated proteins (MAP4, Parysek et al., 1984; tau and cytoplasmic dynein, Ashman et al., 1992; Yoshida et al., 1994; and kinesin, Hall et al., 1992) have been reported to be localised in the manchette. One striking feature is the sudden disruption and dissolution of the manchette during step 15 of spermiogenesis simultaneous with the rapid migration of the annulus along the axoneme, and no remnant of the manchette can be seen in late spermatids or spermatozoa (Lalli and Clermont, 1981). A hypothesis trying to explain the manchette function proposes that it is involved in nuclear shaping on the basis that improper positioning of the manchette is associated with an abnormal sperm head or nuclear shaping (Cole et al., 1988). Also, the manchette can eventually create cytoplasmic currents to rearrange organelles (like mitochondria) in the cytoplasmic lobe. It is feasible that unidentified microtubular translocator proteins are present on the manchette that would serve to transport proteins (e.g., cytoskeletal proteins) up or down its length (Vale et al., $1985 \mathrm{a}, \mathrm{b}$ ). Ultimately, most of the spermatid cytoplasm is lost as the residual body is pinched off. 


\section{Introduction}

In addition to the changes in the nucleus during spermiogenesis, the tail of the spermatozoon, which is the motor apparatus of the sperm, is also formed. The synthesis of both tail and axoneme of the spermatozoon requires the formation of an elaborate microtubular structure associated with numerous unique fibrous sheath and sperm tail proteins. The axoneme of spermatids, which is triggered by the distal centrioles, consists of two central microtubules surrounded by 9 microtubule doublets. (This structure is called the axoneme) The arms associated with the outer doublets are composed of dynein, which are motor protein that drive the flagellar movement. Dynein hydrolyses molecules of ATP and can convert the released chemical energy into mechanical energy that propels the sperm. This energy allows the active sliding of the outer doublet microtubules, causing the flagellum to bend (Ogawa et al., 1977; Shinyoji et al. 1998). The ATP is generated by highly specialized mitochondria in the anterior part of the sperm tail (called the midpiece), where the ATP is needed (Alberts, 1994). The essential role of dynein in motility is demonstrated by immotile cilia syndrome (Gilbert, 2000). The flagella of mammalian sperm and some other species have nine outer dense fibers (ODFs), one per axonemal doublet composed mainly of keratin surrounding the axoneme. The ODFs decrease in diameter from the proximal to the distal extremity of the middle piece. These dense fibers are stiff and noncontractile, and are involved in flagellar flexibility. Absence

of outer dense fibers alters flagellar flexibility and results in modified flagellar beat, causing sterility (Browder et al., 1991; Shostak, 1991).

In this work, two genes with a strong testis expression were isolated and characterized. The presence of the gene products of these two genes in elongated and late spermatids suggests that these genes could play a role in the maturation of spermatozoa.

\section{Objectives of this Work:}

1) Analysis of the expression pattern of both Hook1 and TSEP22 genes.

2) Characterization of the genomic organisation and chromosomal localisation of both genes.

3) Generation of a fusion protein and specific antibodies against both Hook1 and TSEP22 proteins. 


\section{Introduction}

4) Immunohistochemical analysis of both Hook1 and TSEP22 gene products.

5) Subcellular localisation of both genes with green fluorescent fusion proteins.

6) Elucidation of the genetic basis of the azh mutation. 


\section{MATERIALS AND METHODS}

\subsection{Solutions, Chemicals and Laboratory Material}

\subsubsection{Solutions and Buffers}

Solutions were prepared according to Sambrook et al., (1989) with deionised $\mathrm{dH}_{2} \mathrm{O}$, unless otherwise stated.

$\begin{array}{lcl}\text { Denaturation solution } & 0.5 \mathrm{M} & \mathrm{NaOH} \\ & 1.5 \mathrm{M} & \mathrm{NaCl} \\ \text { 50x Denhardt's Solution } & 1 \% & \text { Ficoll } \\ & 1 \% & \text { Polyvinylpyrrolidon } \\ & 1 \% & \mathrm{BSA}, \mathrm{pH} 7.0\end{array}$

The sterile filtrated solution was stored at $-20^{\circ} \mathrm{C}$.
DEPC-dH $\mathrm{H}_{2} \mathrm{O}$
$0.1 \%(\mathrm{v} / \mathrm{v})$
Dimethyl-dicarbonate (DEPC)

DEPC was solved in $\mathrm{dH}_{2} \mathrm{O}$, incubated $24 \mathrm{~h}$ at RT and afterwards autoclaved.

\begin{tabular}{|c|c|c|}
\hline Loading buffer & $\begin{array}{c}0.1 \% \\
0.1 \% \\
15 \%\end{array}$ & $\begin{array}{l}\text { Bromphenol blue } \\
\text { Xylene cyanole } \\
\text { Ficoll } 400\end{array}$ \\
\hline Neutralisation Solution & $\begin{array}{c}0.5 \mathrm{M} \\
1.5 \mathrm{M}\end{array}$ & $\begin{array}{l}\text { Tris/HCl, pH } 7.0 \\
\mathrm{NaCl}\end{array}$ \\
\hline \multirow[t]{3}{*}{ 10x PBS } & $1.3 \mathrm{M}$ & $\mathrm{NaCl}$ \\
\hline & \multicolumn{2}{|c|}{$70 \mathrm{mM} \mathrm{Na}_{2} \mathrm{HPO}_{4}$} \\
\hline & $30 \mathrm{mM}$ & $\mathrm{NaH}_{2} \mathrm{PO}_{4}, \mathrm{pH} 7.4$ \\
\hline PBT & $0.1 \%(\mathrm{v} / \mathrm{v})$ & Tween 20 in $1 x$ PBS \\
\hline 20x SSC & $\begin{array}{c}3 \mathrm{M} \\
0.3 \mathrm{M}\end{array}$ & $\begin{array}{l}\mathrm{NaCl} \\
\text { Sodium acetate, } \mathrm{pH} 7.0\end{array}$ \\
\hline 5x TBE buffer & $\begin{array}{l}445 \mathrm{mM} \\
445 \mathrm{mM} \\
10 \mathrm{mM} \text { EDTA }\end{array}$ & $\begin{array}{l}\text { Tris base } \\
\text { Boric acid, } \mathrm{pH} 8.6\end{array}$ \\
\hline 10x TE buffer & $\begin{array}{l}100 \mathrm{mM} \\
1 \mathrm{mM} \text { EDTA }\end{array}$ & Tris/HCl, pH 8.0 \\
\hline
\end{tabular}

\subsubsection{Chemicals.}

All the chemicals used in this work when not indicated were bought from Fluka, Deisenhofen, Sigma, Deisenhofen or ICN, Eschwege.

Acrylamide/Bis-acrylamide 40\% (w/v, GIBCO/BRL, Eggenstein 


\section{Material and Methods}

19:1)

Agar

Agarose

Ammonium acetate

Ampicillin

Ampuwa $\mathrm{H}_{2} \mathrm{O}$

Antibiotics

Anti-Digoxygenin-antibody conjugated

ATP (Adenosine triphosphate)

Bis-acrylamide

Blocking reagent

Bromphenol blue

BSA (Fraction V)

Cell culture medium

Chloroform

CSPD

Dextran sulfate

Dimethyl sulfoxide

DTT (Dithiothreitol)

DNA-Marker V

DNase I

DNase I (RNase free)

dNTPs

Ethidium bromide

Ficoll 400

FCS, Fetal Calf Serum

Formaldehyde

Formamide

Gel Extraction Kit

Glycerin
Fluka, Neu-Ulm

GIBCO/BRL, Eggenstein; peqLab, Erlangen

Fluka, Neu-Ulm

Sigma, Deisenhofen

Fresenius, Bad Homburg

Sigma, Deisenhofen, GIBCO/BRL, Eggenstein

Roche, Penzberg

Fluka, Deisenhofen

Serva, Heidelberg

Roche, Penzberg

Sigma, Deisenhofen

Biomol, Hamburg, ROTH, Karlsruhe

GIBCO/BRL, Eggenstein

Baker, Deventer, Holland

Roche, Penzberg

Pharmacia, Freiburg

Sigma, Deisenhofen

Sigma, Deisenhofen

Roche, Penzberg

Worthington Biochemical Corporation, New Jersey, USA

Promega, Mannheim

GIBCO/BRL, Eggenstein

ROTH, Karlsruhe

Pharmacia, Freiburg

GIBCO/BRL, Eggenstein

GIBCO/BRL, Eggenstein

ROTH, Karlsruhe, QIAGEN, Hilden

GIBCO/BRL, Eggenstein 


\section{Material and Methods}

Glycine

HEPES

HexaLabel $^{\mathrm{TM}}$ DNA Labeling Kit

IPTG

$1 \mathrm{~Kb}$ Ladder

Klenow DNA Polymerase

Lithium chloride

Lithium acetate

$\beta$-Mercaptoethanol

Mineral oil

NBT (4-Nitroblue-Tetrazolium-Chloride)

Orange G

Peptone

Phenol

Plasmid Mini Preparation Kit

Plasmid Midi-Preparation Kit

Polyethylene glycol 6000 (PEG 6000)

Protein Multicolored Marker

Proteinase K

$\left[\alpha-{ }^{32} \mathrm{P}\right] \mathrm{dCTP}$

$\left[\gamma_{-}{ }^{32} \mathrm{P}\right] \mathrm{dATP}$

Restriction endonucleases

RNase A

RNase H

RNase-Inhibitor

RNA Marker

RNase ZAP

Roticlear

Salmon Sperm DNA

SDS (Sodium dodecyl sulfate)
Sigma, Deisenhofen

GIBCO/BRL, Eggenstein

MBI Fermentas, St. Leon-Rot

Biomol, Hamburg

GIBCO/BRL, Eggenstein

Amersham, Braunschweig

Sigma, Deisenhofen

Sigma, Deisenhofen

Serva, Heidelberg

Sigma, Deisenhofen

Fluka, Deisenhofen

Sigma, Deisenhofen

GIBCO/BRL, Eggenstein

GIBCO/BRL, Eggenstein

GIBCO/BRL, Eggenstein

Genomed, Bad Oeynhausen

Serva, Heidelberg

Invitrogen, Holland

Pharmacia, Freiburg

Amersham, Braunschweig

Amersham, Braunschweig

GIBCO/BRL, New England Biolabs, MBI, St. Leon-Rot

Sigma, Deisenhofen

GIBCO/BRL, Eggenstein

Roche, Penzberg

GIBCO/BRL, Eggenstein

Ambion, Wiesbaden

ROTH, Karlsruhe

Sigma, Deisenhofen

Serva, Heidelberg 


\section{Material and Methods}

T4 DNA-Ligase

Taq-DNA-Polymerase

Titanium Taq-DNA-Polymerase

TEMED

Titan $^{\mathrm{TM}}$ One Tube RT-PCR System

t-RNA

Triton X-100

Tween 20

X-Gal

X-Phosphate/BCIP

Xylene cyanole

Yeast extract
GIBCO/BRL, Eggenstein

GIBCO/BRL, Eggenstein, FINNzymes,

Clontech, Heidelberg

Serva, Heidelberg

Roche, Penzberg

Roche, Penzberg

Serva, Heidelberg

Fluka, Deisenhofen

Biomol, Hamburg

Sigma Deisenhofen

Bio-Rad, München

GIBCO/BRL, Eggenstein

\subsubsection{Laboratory Material.}

The laboratory material not listed was bought from the companies Schütt and Krannich (Göttingen).

Blotting membrane GB 003 and GB 004

Cell culture bottles

Dialysis hoses

Disposable filter Minisart NMI

Filter paper 0858

HPTLC Aluminum folio 60 F 254

Hybond C Membrane

Hybond N Membrane

Petri boxes

Pipette tips

Reaction tubes

Transfection bottles

Ultracentrifuge tubes

$\mathrm{X}$-ray films
Schleicher and Schüll, Dassel

Greiner, Nürtingen

Serva, Heidelberg

Sartorius, Göttingen

Schleicher and Schüll, Dassel

Merck, Darmstadt

Amersham, Braunschweig

Amersham, Braunschweig

Greiner, Nürtingen

Eppendorf, Hamburg

Eppendorf, Hamburg

Lab-Tek/Nalge Nunc, IL, USA

Nalgene,

Amersham, Braunschweig 


\subsection{Culture Mediums for Bacteria and Mammalian Cells}

\subsubsection{Bacteria Culture Medium}

\subsubsection{LB Medium}

All media for bacteria were prepared with $\mathrm{dH}_{2} \mathrm{O}$, autoclaved and stored at $4^{\circ} \mathrm{C}$. Plates were also stored at $4{ }^{\circ} \mathrm{C}$. Antibiotics, IPTG (Isopropyl- $\beta$-thiogalactopyranoside) and XGal (5-Bromo-4-chloro-3-indolyl- $\beta$-D- Galactopyranoside) were added to the cooled $\left(\sim 50^{\circ} \mathrm{C}\right)$ sterile media.

\begin{tabular}{|c|l|}
\hline \multicolumn{1}{|c|}{ Medium } & \multicolumn{1}{c|}{ Composition } \\
\hline LB-Medium (pH 7,5) & $1 \%(\mathrm{w} / \mathrm{v})$ Peptone or Bacto-Tryptone \\
& $0.5 \%(\mathrm{w} / \mathrm{v})$ Yeast extract \\
& $0.5 \%(\mathrm{w} / \mathrm{v}) \mathrm{NaCl}$ \\
& LB plates contain $1.5 \%(\mathrm{w} / \mathrm{v})$ Agar \\
& LB Top Agar contain $0.7 \%(\mathrm{w} / \mathrm{v})$ Agarose \\
\hline LB-Amp-Medium & LB-Medium with $100 \mu \mathrm{g} / \mathrm{ml}$ Ampicillin \\
LB-Kan-Medium & LB Medium with $25 \mu \mathrm{g} / \mathrm{ml}$ Kanamycin \\
LB-Amp-IPTG-X- & LB Medium with $100 \mu \mathrm{g} / \mathrm{ml}$ Ampicillin, $833 \mu \mathrm{M}$ IPTG, \\
Gal Medium (Oja) & $0.4 \%(\mathrm{w} / \mathrm{v})$ X-Gal. \\
\hline
\end{tabular}

Antibiotics stock solutions:

$\begin{array}{lc}\text { Ampicillin } & 100 \mathrm{mg} / \mathrm{ml} \\ \text { Kanamycin } & 25 \mathrm{mg} / \mathrm{ml} \\ \text { IPTG } & 0.2 \mathrm{~g} / \mathrm{ml} \\ \text { X-Gal } & 8 \% \text { in } \mathrm{N}^{\prime}-\mathrm{N}^{\prime} \text {-Dimethyl-formamide }\end{array}$

All these solutions were prepared with $\mathrm{dH}_{2} \mathrm{O}$ (except X-Gal), sterile filtrated and stored at $-20^{\circ} \mathrm{C}$.

\subsubsection{Mammalian Cells Culture Media}

\subsubsection{3T3 Cells Medium}

$\begin{array}{lr}\text { 3T3 Cells Medium } & 500 \mathrm{ml} \\ \text { (DMEM+) } & 50 \mathrm{ml} \\ & 6 \mathrm{ml} \\ 6 \mathrm{ml}\end{array}$

Dulbecco's MEM (DMEM), Fetal bovine serum (FBS)

Glutamine

Penicillin $(6 \mathrm{mg} / \mathrm{ml}) /$ Strepto-mycin (5mg/ml) 


\section{Material and Methods}

The FBS was heat inactivated at $56^{\circ} \mathrm{C}$ for $30 \mathrm{~min}$. All the components were added to the Dulbecco's MEM by sterile filtration through $0.45 \mu \mathrm{m}$ disposable filters. It was stored at $4^{\circ} \mathrm{C}$.

Trypsin-EDTA: $\quad 2.5 \mathrm{mg} / \mathrm{ml} \quad$ Trypsin

$2.0 \mathrm{mg} / \mathrm{ml} \quad$ EDTA in Puck's Saline

solution A (GIBCO/BRL)

\subsubsection{Sterilization Procedure}

The media and solutions were sterilized for $20 \mathrm{~min}$ at $121^{\circ} \mathrm{C}$ and $10^{5}$ Pascal in a vapor pressure autoclave. Thermolabile solutions like antibiotics were sterile filtrated. The solutions were prepared with deionised $\mathrm{H}_{2} \mathrm{O}$ or Ampuwa $\mathrm{H}_{2} \mathrm{O}$ (pyrogene free $\mathrm{H}_{2} \mathrm{O}$ for molecular biology work). The solutions for RNA preparations and RNA analyses were handled with dimethyl-dicarbonate (DEPC) to avoid any RNase contamination.

\subsection{Biological Material}

\subsubsection{Bacterial Strains}

The following Escherichia coli K 12 strains were used:

DH5 $\alpha$, for cloning: $\quad \quad \mathrm{F}^{-}$Ф80d lacZ $\quad$ M15 endA1 recA1 hsdR17 $\left(\mathrm{r}_{\mathrm{k}}^{-}, \mathrm{m}_{\mathrm{k}}^{+}\right)$ sup E44 thi-1 d' gyrA96 $\Delta$ (lacZYA-arg)

XL1-blue, for cloning: $\quad \mathrm{F}^{\prime}:: \operatorname{Tn} 10\left(\mathrm{Tet}^{\mathrm{r}}\right) \operatorname{proA}^{+} \mathrm{B}^{+} 1 \quad$ lacl $^{\mathrm{q}} \quad \Delta(\mathrm{lacZ}) \mathrm{M} 15 / \mathrm{rec} A 1$ end A1 gyrA96 Nal $\left.{ }^{\mathrm{r}}\right)$ thi-1 hsdR17( $\left.\mathrm{r}_{\mathrm{k}}^{-}, \mathrm{m}_{\mathrm{k}}{ }^{+}\right)$supE44 relA1 lac

XL1 blue MRF', for phage propagation: $\quad \Delta$ (mcrA) $183 \Delta$ (mcrCB-hsdSMR-mrr) 173endA1 supE44thi-1recA1gyrA96relA1 lac [F' pro $\left.A B \operatorname{lacl}^{\mathrm{q}} \mathrm{Z} \Delta \mathrm{M} 15 \operatorname{Tn} 10\left(\operatorname{Tet}^{\mathrm{r}}\right)\right]$

Top10, for propagation of $\mathrm{pZErO}^{\mathrm{TM}}-2$ (Invitrogen, Wiesbaden)

\subsubsection{Vectors}

The following vectors were used:

pASK-IBA II (IBA)

to generate a fusion protein under a tet-on control 
pBluescript II $\mathbf{K S}^{+}$(Stratagene) for standard cloning

pBluescript II SK (Stratagene) for standard cloning

pEGFP-C1 (Clontech)

pGEM-TEasy (Promega)

to generate a green fluorescent fusion protein

pZErO $^{\text {TM }}$-2 (Invitrogen)

to clone PCR fragments

to clone fragments bigger than $6 \mathrm{~kb}$

\subsubsection{Antibodies}

The following antibodies were used:

$\alpha$-DIG, conjugated to alkaline phosphatase (Roche, Penzberg)

Goat $\alpha$-rabbit-IgG, conjugated to alkaline phosphatase (Sigma)

Goat $\alpha$-mouse-IgG, conjugated to alkaline phosphatase (Sigma)

Mouse monoclonal $\alpha$-mouse tubulin (Sigma)

Rabbit $\alpha-C y 3$ antibody (Sigma)

Rabbit $\alpha$-mouse Hook1 protein (generated in this work)

Rabbit $\alpha$-mouse TSEP22 protein (generated in this work)

\subsubsection{DNA Libraries}

The following DNA libraries were used:

\begin{tabular}{|c|c|c|c|c|}
\hline LIBRARY & VECTOR & HOST CELL & $\begin{array}{c}\text { CLONING } \\
\text { SITE }\end{array}$ & $\begin{array}{c}\text { INSERT } \\
\text { LENGTH }\end{array}$ \\
\hline $\begin{array}{c}\text { Mouse testis cDNA library } \\
\text { (Stratagene) }\end{array}$ & Uni-ZAPTMXR & $\begin{array}{c}\text { XL1-Blue MRF' } \\
\text { SOLR }\end{array}$ & EcoRI/XhoI & $0.5-3.0 \mathrm{~Kb}$ \\
$\begin{array}{c}\text { Mouse testes cDNA library } \\
\text { (RZPD), 3 filters set } \\
\begin{array}{c}\text { Mouse-genomic DNA library } \\
\text { (RZPD), 11 filters set }\end{array}\end{array}$ & pSPORT 1 & E. coli DH10B & Sall/NotI & $0.6-2 \mathrm{~Kb}$ \\
\hline
\end{tabular}

\subsubsection{Mouse Strains}

The following mouse strains were used: 


\begin{tabular}{|c|l|}
\hline $\begin{array}{c}\text { MOUSE } \\
\text { STRAIN }\end{array}$ & \multicolumn{1}{c|}{ OBSERVATIONS } \\
\hline NMRI & wild type strain \\
W/W & $\begin{array}{l}\text { without testicular germ cells due to a mutation in the c-kit receptor; therefore, } \\
\text { there is a decreased germ cell proliferation and lack of migration of germ cells } \\
\text { into the gonadal anlage (Tan et al., 1990). } \\
\text { arrest of the spermatogenesis at the stage of primary spermatocytes due to a } \\
\text { defect in the androgen receptor (Lyon and Hawkes, 1970; Attardi and Ohno, } \\
\text { 1974). } \\
\text { Trm/Y } / \mathbf{Y}\end{array}$ \\
$\mathbf{o l t} / \mathbf{o l t}$ & $\begin{array}{l}\text { arrest of the spermatogenesis in the early spermatid stage (Moutier, 1976). } \\
\text { 1971). } \\
\text { abnormal spermatozoon head shape (Hugenholtz, 1984). }\end{array}$ \\
$\mathbf{a z h} / \mathbf{a z h}$ &
\end{tabular}

\subsubsection{Mammalian cells}

NIH/3T3 Immortalized swiss albino mouse embryo fibroblasts.

$15 P 1 \quad$ Immortalized Sertoli cells.

\subsubsection{Primers}

All the primers used in this work were synthesized by the company NAPS (Göttingen) or by the company ROTH (Karlsruhe) and were adjusted to a stock concentration of 100 pmol/ $\mu \mathrm{l}$ with Ampuwa $\mathrm{H}_{2} \mathrm{O}$.

T7 promoter primer: 5'- TAA TAC GAC TCA CTA TAG GG-3'

T3 promoter primer: 5' - ATT AAC CCT CAC TAA AG-3'

Sp6 promoter primer: 5' - AGG TGA CAC TAT AGA ATA C-3'

T7 modified: $\quad 5$ ' $\quad$ TAA TAC GAC TCA CTA TAG GG-3'

5'PCR: $\quad$ 5'- GGT GAG GCA GTC TTG AAT GT-3'

P1: $\quad$ 5'- GGC GCC CGC GCC ACT CAC GCG CGA AG-3'

P2: $\quad$ 5'- GTC AAC GAC CTC CGC GCC CGC CAC T-3'

5PE: $\quad 5$ '- GCC ATC CAA CTG GTC AAG CT-3'

5p: $\quad$ 5'- GCC ACA GTA CGA GCT GCC GCT-3'

5PCR: $\quad 5{ }^{\prime}$ - ACA TTC AAG ACT GCC TCA CC-3'

I: $\quad 5^{\prime}-$ GCG GTG GGC GAG GGG GCG GTC -3' 
II:

III:

IV:

3.5 BE:

A:

B:

C:

D:

E:

H1:

H2:

H3:

H3b:

H4:

H5:

H6:

H7:

H8:

H8a:

H8b:

H8c:

H9:

H10:

H11:

H12:

H13:

H31:

H32:

H33:

H34:

H35:
5'- GCA TGG AGT CTC GGC TGG TGA GT -3'

5'- CTT CCG TTG TGT TTG CTT TGC -3'

5'- GCA GAA GTT GGA AGC TCA TAT G -3'

5'- GTA CAA TAC CAC ATC CAC CT-3'

5'-GCT ATG GCC TCC TGA AGC TCT -3'

5'- CCG TGT TCA CTG TGA GGA ACT-3'

5'- GGC TTG AAG AAA AAC ATG AA-3'

5'- GCC AGC TGC TTT CTG AGT AA-3'

5'- CCA GGC TCT TGT TAT ACC AGG CAG AA-3'

5'- CCG TGA GGC TTC GCG CGT GAG TGG CG-3'

5'- CTC CAT TAG TCA GCT GTT TGA CAT CTT-3'

5'- ATA TAA TGA CCC TGG AAG AAT CTG TT-3'

5'- ACA TTC AAG ACT GCC TCA CCT TGT CAA-'

5'- AGT CAT GAC CAC ATG TTG AAC AGA TT-3'

5'- AAG CTT GAC CAG TTG GAT GGC TCT-3'

5' - TTG TTC TAG TTG TAG CTG TAC GTG-3'

5'- TGG AGG TAT ATC GTC AGA AGC TAC AAG-3'

5'- GTC TCT AAC TGT GCC CGA GCT GCG TT-3'

5'- GTG TAT CTG CCC TTT TGG ATT CAG-3'

5'- GTT ATG AAA ATC TTG CTG CTG AGA-3'

5'- GCA TGA TCT CAG CAG CAA GAT TTT-3'

5'- TAC AGC AAG AAG GGA CGG AGA ATG AAC-3'

5' - TCA TTC ATC TTG CGG TGC TTC TG-3'

5'- GTG AAC TTG AAG CGG CTC TTC AGA A-3'

5' - TTC TGA AGA GCC GCT TCA AGT TCA CTG-3'

5'- CTT GTT ATA CCA GGC AGA AAC AAT G-3'

5'- GTA GCT TGG TTC AGC GAA TCT TGG-3'

5'- CGG CTT AAC CAA GAT TCG CTG AAC-3'

5' - CCT AGT AAC CTG AAG AAG GTC CTC-3'

5'- GTA ACT TGT AAT TCC ATG GAG GAC-3'

5'- CAA ATC ACT GAG TGT GCA GAT CCT-3' 

H36:
5'- GCA CAT CCT AGA ATT AGC TGA AGC-3'
HPF:
5'- GTA TTC GGT CTC TGG CCC AAG AAG
GGA CGG AGA ATG A-3
HPR:
5'- GTA TAC GGT CTC TGC GCT TTC CTC
ATA ATC CCT CAA TT-3'
GAPDHfor: $\quad$ 5'- CAT CAC CAT CTT CCA GGA GC-3'
GAPDHrev: $\quad 5$ '- ATG ACC TTG CCC ACA GCC TT-3'

\subsection{Preparation of Nucleic Acids}

\subsubsection{Mini-Preparation of Plasmid DNA}

The isolation of high quality DNA appropriate for sequencing (2.8.3) was performed according to the protocol of the "CONCERT Plasmid Mini Kit" from the company GIBCO using the buffers provided in the kit. The method comprises the lysis of bacteria under alkaline conditions (modificated from Birnboim and Doly, 1979), ending with the purification of the plasmid DNA through a column.

\subsection{2 . Standard Mini-Preparation of Plasmid DNA}

This method was used to check the results after cloning. From an overnight bacteria culture, $1.5 \mathrm{ml}$ were transferred to an Eppendorf tube and centrifuged at 4,000x g for 10 min. The supernatant was discarded and the step was repeated from the beginning. The rests of medium were eliminated by inversion on absorbent paper. The pellet was resuspended in $150 \mu \mathrm{l}$ of buffer E1. For lysis $200 \mu \mathrm{l}$ of E2 buffer were added and mixed by inverting the tube 5-6 times, the incubation was conducted by $30 \mathrm{sec}$ at RT. The sample was neutralized with $200 \mu \mathrm{l}$ of E3 buffer and mixed by inversion 4-5 times. After a centrifugation for $15 \mathrm{~min}$ at $14,000 \mathrm{x}$ g, the supernatant was pipetted into a new Eppendorf tube and centrifuged again under the same conditions. The DNA in the last supernatant was precipitated with 3 vol of ice cold $100 \%$ Ethanol and pelleted by centrifugation at $14,000 \mathrm{x}$ g for $15 \mathrm{~min}$. The DNA pellet was washed with $500 \mu 1$ of $70 \%$ Ethanol and centrifuged again for $5 \mathrm{~min}$. Then the pellet was dried and resuspended in 30 $\mu 1$ of Ampuwa $\mathrm{H}_{2} \mathrm{O}$. 
E1 Buffer:

E2 Buffer:

E3 Buffer:

$\begin{array}{cl}50 \mathrm{mM} & \text { Tris/HCl, pH } 8.0 \\ 10 \mathrm{mM} & \text { EDTA } \\ 100 \mu \mathrm{g} / \mathrm{ml} & \text { RNase A }\end{array}$

$200 \mathrm{mM} \quad \mathrm{NaOH}$ $1 \%(\mathrm{w} / \mathrm{v}) \mathrm{SDS}$

$3 \mathrm{M} \quad$ Potassium acetate, $\mathrm{pH} 5.5$

\subsubsection{Midi-Preparation of Plasmid DNA using Columns.}

High quality plasmid DNA was prepared with the anion exchange chromatography columns from the Genomed kit. For a midi preparation, $200 \mathrm{ml}$ of an overnight culture (in LB medium plus antibiotic) was centrifuged at 4,000x g for $10 \mathrm{~min}$. The bacteria pellet was resuspended in E1 buffer containing $100 \mu \mathrm{g} / \mathrm{ml}$ of RNase A. After lysis (E2 buffer) and neutralisation (E3 buffer) the suspension was centrifuged (15 min, 13,000x g). The supernatant containing the DNA was applied to a previously equilibrated column (with E4 buffer) and let run by gravity, there the DNA is caught by the anion exchange matrix. The DNA was purified from metabolites in 2 wash steps with buffer E5, then it was eluted with an elution buffer (E6) and after addition of isopropanol was pelleted by centrifugation at $13,000 \mathrm{x} \mathrm{g}, 4^{\circ} \mathrm{C}$ for $30 \mathrm{~min}$. The pellet was dried, resuspended in Ampuwa $\mathrm{H}_{2} \mathrm{O}$ and stored at $-20^{\circ} \mathrm{C}$ until use.

Buffer E4

$$
\begin{array}{ll}
600 \mathrm{mM} & \mathrm{NaCl} \\
100 \mathrm{mM} & \mathrm{NaAc}, \mathrm{pH} 5.0 \\
0.15 \%(\mathrm{w} / \mathrm{v}) & \text { TritonX-100 }
\end{array}
$$

$\begin{array}{lcl}\text { Buffer E5: } & 800 \mathrm{mM} & \mathrm{NaCl} \\ & 100 \mathrm{mM} & \mathrm{NaAc}, \mathrm{pH} 5.0 \\ & & \\ \text { Buffer E6: } & 1.25 \mathrm{M} & \mathrm{NaCl} \\ & 100 \mathrm{mM} & \text { Tris/HCl, } \mathrm{pH} 8.0\end{array}$

\subsubsection{In vivo Excision of Phagemids}

This method was used to isolate recombinant DNA of phage clones from a mouse testis cDNA library. The Uni-ZAP-XR vector allows a fast isolation of recombinant DNA, due to an in vivo excision of the pBluescript SK vector contained in the phagemid via the Exassist-helper-phage (M13). For this, $200 \mu \mathrm{l}$ of an overnight culture of the bacteria 
strain E. coli XL1-Blue were incubated with $100 \mu$ of the pure phage stock and $1 \mu 1$ of the helper phage for $15 \mathrm{~min}$ at $37^{\circ} \mathrm{C}$. After the addition of $3 \mathrm{ml} \mathrm{LB}$ medium, the suspension was agitated for $2-2.5 \mathrm{~h}$ more at $37^{\circ} \mathrm{C}$, until lysis was completed. To eliminate the surviving host bacteria, the sample was incubated at $70^{\circ} \mathrm{C}$ for $20 \mathrm{~min}$. After centrifugation $(4,000 \mathrm{x} \mathrm{g}, 15 \mathrm{~min})$ the supernatant was transferred to a new sterile recipient. This stock contains the heat resistant phagemid pBluescript SK with the desired DNA fragment. The positive clones were cloned into the Lambda resistant E. coli strain SOLR, (Stratagene) and changing the antibiotic selection from kanamycin to ampicillin. From here, $100 \mu \mathrm{l}$ of the supernatant were pre-incubated with $200 \mu \mathrm{l}$ of bacteria for 15 min at $37^{\circ} \mathrm{C}$, then, they were incubated overnight at $37^{\circ} \mathrm{C}$ in selective plates. The positive clones were analyzed with a plasmid preparation (2.4.2.), restriction analysis, sequencing (2.8.3.), colony hybridisation (2.10.3.) or PCR with plasmid or sequence specific primers (2.8.1.).

\subsubsection{Isolation of Total RNA}

In order to avoid any RNase activity, all equipment and solutions used for RNA isolation were previously treated with RNase AWAY and DEPC water. Special RNase free Eppendorf cups were used during the procedure. In this method, RNA is extracted in a denaturing solution of Guanidine-Isothiocyanate (GITC). Adult mice tissues (brain, liver, lung, kidney, ovary, testis, spleen, heart) were collected and used immediately for the RNA isolation. All of the collected tissues were separately prepared. $100 \mathrm{mg}$ of tissue were mixed with $1 \mathrm{ml}$ of the GITC buffer solution (Total-RNA solution, Biomol) and then homogenized 10-20 sec with an electric homogenisator (Ultraturrax T25, Schütt). Then, 0.2 vol of ice-cold chloroform were added and mixed, and the samples were placed on ice for $5 \mathrm{~min}$. After centrifugation of the suspension at $3,200 \mathrm{x}$ g for $10 \mathrm{~min}$ at $4^{\circ} \mathrm{C}$, the upper phase was taken and mixed with 1 vol of ice-cold isopropanol and placed on the ice for $15 \mathrm{~min}$. Then, the RNA was precipitated at $13,000 \mathrm{x} \mathrm{g}$ at $4{ }^{\circ} \mathrm{C}$ and the pellet was washed with $1 \mathrm{ml}$ of ice-cold $75 \%$ ethanol. After that, the pellet was dried at room temperature (RT) and finally resuspended in 50-100 $\mu 1$ of $\mathrm{DEPC}-\mathrm{H}_{2} \mathrm{O}$. To avoid protein contamination, the samples were incubated at $65^{\circ} \mathrm{C}$ for $0.5-2 \mathrm{~min}$, cooled in ice and the 
denatured proteins were pelleted by centrifugation for $30 \mathrm{sec}$. The RNA aliquots were stored at $-80^{\circ} \mathrm{C}$. The RNA concentration was determined with a spectrophotometer.

\subsubsection{Phenol-Chloroform Extraction}

This procedure purifies the nucleic acids after an enzymatic handling. One vol of phenol was added to the sample, vortexed and centrifuged at $13,000 \mathrm{x} g$ for $2 \mathrm{~min}$. The supernatant was transferred to a new reaction tube and 1 vol of chloroform was added. After vortexing and centrifuging as before, the supernatant was transferred again to a fresh reaction tube and the ethanol precipitation of the nucleic acids was made.

\subsubsection{Ethanol Precipitation of Nucleic Acids}

To precipitate nucleic acids, the salt concentration of the sample was adjusted to $300 \mathrm{mM}$ with $\mathrm{NaCl}$ or with 0.1 vol of $3 \mathrm{M} \mathrm{NaAc}(\mathrm{pH} 4.8)$ and 2.5 vol of $100 \%$ Ethanol was added. The sample was placed at $-80^{\circ} \mathrm{C}$ for $20 \mathrm{~min}$ and pelleted by centrifugation $\left(13,000 \mathrm{x} g, 15 \mathrm{~min}, 4^{\circ} \mathrm{C}\right)$. The pellet was washed with $70 \%$ Ethanol, centrifuged, dried and solved in an appropriate vol of $\mathrm{H}_{2} \mathrm{O}$. The sample was then checked electrophoretically.

\subsection{Enzymatic Modification of DNA}

\subsubsection{Dephosphorylation of 5' DNA Ends}

The dephosphorylation of the $5^{\prime}$ ends of DNA prevents the recircularisation of a previously restricted vector with compatible cohesive ends during a ligation experiment. This was achieved with the alkaline phosphatase (CIP from calf intestine), which removes the 5' phosphate from the free ends of the DNA molecules. Therefore, the efficiency of the ligation of foreign DNA into a vector can be greatly enhanced. This treatment of the DNA was carried out as follows:

\begin{tabular}{ll}
$1 \mu \mathrm{g}$ & Digested vector DNA \\
$1 \mu \mathrm{l}$ & CIP, alkaline phosphatase $(5 \mathrm{U} / \mu \mathrm{l})$ \\
$1 \mu \mathrm{l}$ & 10x CIP buffer \\
$\mathrm{x} \mu \mathrm{l}$ & Ampuwa $\mathrm{H}_{2} \mathrm{O}$ \\
\hline $\mathbf{2 0} \boldsymbol{\mu l}$ & Total volume
\end{tabular}


The reaction was performed at $37^{\circ} \mathrm{C}$ for $1 \mathrm{~h}$ and was then terminated by heat inactivation at $68^{\circ} \mathrm{C}$ for $15 \mathrm{~min}$ and the addition of 0.1 vol of $10 \%(\mathrm{w} / \mathrm{v})$ SDS and 0.1 vol $10 \mathrm{x}$ TE buffer. After a phenol/chloroform extraction, the DNA was ethanol precipitated with 0.1 vol of $3 \mathrm{M} \mathrm{NaAc}(\mathrm{pH} 4.8)$.

10 x CIP buffer:

$$
\begin{aligned}
500 \mathrm{mM} & \text { Tris/HCl, } \mathrm{pH} 9.0 \\
10 \mathrm{mM} & \mathrm{MgCl}_{2} \\
1 \mathrm{mM} & \mathrm{ZnCl}_{2} \\
10 \mathrm{mM} & \text { Spermidine }
\end{aligned}
$$

\subsubsection{Cloning of DNA Fragments}

Foreign DNA fragments were subcloned into vectors after digestion with restriction enzymes, electrophoresis separation (2.9.1.), isolation (2.6.) and finally ligation into a vector. The vector was cut with one or two enzymes, that had a restriction site in the

\begin{tabular}{|c|c|}
\hline $0.5 \mu \mathrm{g}$ & Digested vector DNA \\
\hline $1-10 x$ & Molar ratio of foreign DNA fragment \\
\hline $1 \mu 1$ & T4 DNA ligase enzyme $(5 \mathrm{U} / \mu \mathrm{l})$ \\
\hline $1 \mu 1$ & 10x ligation buffer \\
\hline $\mathrm{X} \mu \mathrm{l}$ & $\mathrm{H}_{2} \mathrm{O}$ \\
\hline $\mathbf{1 0 \mu l}$ & Total volume \\
\hline
\end{tabular}
multicloning site (MCS). When only one enzyme was used to restrict the vector, a dephosphorylation of the $5^{\prime}$ ends (2.5.1.) was performed to prevent the religation of the vector. The ligation reaction was done as follows with an overnight incubation at $16^{\circ} \mathrm{C}$ :

\subsubsection{Cloning of PCR Fragments}

PCR products (2.8.1.) were subcloned through the TA-ligation (TA: thymidine-adenine) if PCR was performed with a Taq polymerase that leaves a deoxyadenosine at the 3 'end of the amplified fragment in the elongation phase of the PCR cycle. The PCR fragments were TA-ligated to the pGEM-T Easy vector (Promega). This vector contains an open insertion site inside the MCS that has a 3'overhanged thymidine where the PCR fragment ligates. The ligation reaction is performed under the same conditions indicated in 2.5.2. 


\subsubsection{RNase H Digestion}

Ribonuclease $\mathrm{H}$ (RNase $\mathrm{H}$ ) selectively removes the poly(A) sequences from mRNA and the RNA strand of RNA-DNA hybrids in a divalent cation-dependent manner. By hybridizing a synthetic oligonucleotide oligo(dT) to the poly(A) of mRNA, the artificially produced double chained DNA/RNA hybrids can be removed by the RNase $\mathrm{H}$, so that poly (A) tails of different lengths can be identified. In this case, $20 \mu \mathrm{g}$ of total RNA of adult mouse testis and $2 \mu \mathrm{g}$ of $15 \mathrm{mer}$ oligo(dT) (Roche, Penzberg) were annealed at $65^{\circ} \mathrm{C}$ for $3 \mathrm{~min}$. Then, $0.25 \mathrm{vol}$ of the $5 \mathrm{x}$ Ribonuclease buffer $\mathrm{H}$ (Roche, Penzberg) were added to the sample and it was placed on ice for $15 \mathrm{~min}$. Later, $1 \mu \mathrm{l}$ of Ribonuclease $\mathrm{H}$ (12 $\mathrm{U} / \mu 1$ ) (Roche, Penzberg) was added to the sample, incubated for $15 \mathrm{~min}$ at $37^{\circ} \mathrm{C}$ and extracted immediately with phenol/chloroform. Next, an ethanol precipitation with $3 \mathrm{M}$ $\mathrm{NaAc}(\mathrm{pH} 4.8)$ was performed.

\subsection{Isolation of DNA Fragments from Agarose Gels}

For the isolation of DNA from agarose gels, the DNA band was cut out from the gel with a sterile scalpel and extracted with the QIAEX II kit (QIAGEN, Hilden). This system is based in the feature that agarose is solved in the presence of high $\mathrm{NaI}$ concentrations. When the DNA is liberated, it binds to added glass particles. For this, $300 \mu 1$ of buffer QX1 (containing NaI) per $100 \mathrm{mg}$ of agarose gel and $10 \mu \mathrm{l}$ glass milk per $5 \mu \mathrm{g}$ DNA were added. This step was followed by incubation at $55^{\circ} \mathrm{C}$ for 10 min with constant mixing and centrifugation at $14,000 \mathrm{x}$ g for $30 \mathrm{sec}$. The pellet was washed again with buffer QX1 and centrifuged like before. Then, the pellet was washed twice with the buffer PE and spinned, the pellet was air-dried at RT for $15 \mathrm{~min}$. To elute DNA, $25 \mu 1$ of Ampuwa water was added to the dry glass milk pellet and was incubated at $55^{\circ} \mathrm{C}$ under shaking for $10 \mathrm{~min}$. The glass milk was pelleted by centrifugation at 13,000x $\mathrm{g}$ and the supernatant was transferred to a new Eppendorf tube: The centrifugation was repeated to eliminate glass milk rests. 


\subsection{E. coli Competent Cells}

\subsubsection{Production of $\boldsymbol{E}$. coli Competent Cells}

By this procedure, the competence of E. coli cells to accept free DNA is artificially increased. This is achieved by modifying the cell wall with $\mathrm{CaCl}_{2}$ and $\mathrm{RbCl} .30 \mathrm{ml}$ of $\mathrm{LB}$ Medium were inoculated with a single bacteria colony (DH5 $\alpha$ or TOP 10) and shaked overnight at $37^{\circ} \mathrm{C}$. At the next day, $1 \mathrm{ml}$ of this pre-culture was added to $100 \mathrm{ml}$ of LB Medium and incubated until an $\mathrm{OD}_{600}=0.5$ was reached. Then, they were cooled down on ice for $10 \mathrm{~min}$ and centrifuged at 5,000x g, $4^{\circ} \mathrm{C}$ for $10 \mathrm{~min}$ (Sorvall RC5B). The cell pellet was resuspended carefully in $30 \mathrm{ml}$ of TFB I (on ice) and was incubated $10 \mathrm{~min}$ on ice. After centrifugation at $5,000 \mathrm{x}$ g at $4{ }^{\circ} \mathrm{C}$ for $10 \mathrm{~min}$, the bacteria were resuspended in TFBII, shock frozen in $200 \mu 1$ aliquots in liquid nitrogen and stored at $-80^{\circ} \mathrm{C}$ until their use.

$\begin{array}{lll}\text { TFB I: } & 100 \mathrm{mM} & \mathrm{RbCl} \\ & 50 \mathrm{mM} & \mathrm{MnCl}_{2} \\ & 10 \mathrm{mM} & \mathrm{CaCl}_{2} \\ & 30 \mathrm{mM} & \mathrm{KAc}, \mathrm{pH} 5.8 \\ & 15 \%(\mathrm{v} / \mathrm{v}) & \text { Glycerin } \\ & & \\ \text { TFBII: } & 10 \mathrm{mM} & \mathrm{RbCl} \\ & 75 \mathrm{mM} & \mathrm{CaCl}_{2} \\ & 10 \mathrm{mM} & \text { MOPS, } \mathrm{pH} 7.0 \\ & 15 \%(\mathrm{v} / \mathrm{v}) & \text { Glycerin }\end{array}$

\subsubsection{Transformation of Competent Bacterial Cells}

$200 \mu 1$ of competent cells (E. coli DH5 $\alpha$ or TOP 10) were thawed on ice (10 min), mixed with 5-10 $\mu$ l ligation reaction mixture and placed on ice for $20 \mathrm{~min}$ with occasional mixing. The transformation reaction mixture was then incubated at $42^{\circ} \mathrm{C}$ for $90 \mathrm{sec}$ for a heat-shock and placed on ice for 2 more min. In order to accelerate the bacteria growth, $300 \mu \mathrm{l}$ of $\mathrm{LB}$ medium was added to the reaction mixture, which was incubated at $37^{\circ} \mathrm{C}$ for $45 \mathrm{~min}$ under shaking. After incubation, $100-150 \mu \mathrm{l}$ of the reaction mixture were spread on the proper selection plate and incubated overnight at $37^{\circ} \mathrm{C}$. 


\subsection{Polymerase Chain Reaction (PCR)}

The polymerase chain reaction is a powerful technique (Saiki et al., 1988) that is widely used for the exponential amplification of specific DNA sequences in vitro by using appropriate synthetic oligonucleotides (primers). The general principle of PCR starts from a pair of oligonucleotide primers that are designed so that a forward or sense primer directs the synthesis of DNA towards a reverse or antisense primer, and viceversa. During the PCR, the Taq DNA polymerase (which is purified from Thermophilus aquaticus and is a heat-stable enzyme) catalyzes the synthesis of a new DNA strand that is complementary to a template DNA from the $5^{\prime}$ to $3^{\prime}$ direction by a primer extension reaction, resulting in the production of the DNA region flanked by the two primers.

\subsubsection{PCR for DNA fragments}

The amplification cycles were performed in an automatic thermocycler (MWG Biotech). The PCR reaction contains in general, the following:

\begin{tabular}{|c|c|c|}
\hline & $.5 \mu \mathrm{g}$ & Genomic DNA or \\
\hline & $50 \mathrm{ng}$ & Plasmid DNA \\
\hline & $1 \mu 1$ & Forward primer $(10 \mathrm{pmol})$ \\
\hline $1 \mu 1$ & & Reverse primer (10pmol) \\
\hline & $1 \mu 1$ & $10 \mathrm{mM}$ dNTPs \\
\hline & $5 \mu 1$ & 10x PCR buffer \\
\hline $1.5 \mu \mathrm{l}$ & & $50 \mathrm{mM} \mathrm{MgCl} 2$ \\
\hline $1 \mu 1$ & & Taq DNA Polymerase $(5 \mathrm{U} / \mu \mathrm{l})$ \\
\hline & $\mathrm{x} \mu \mathrm{l}$ & $\mathrm{H}_{2} \mathrm{O}$ \\
\hline & $\mu \mathbf{l}$ & Total volume \\
\hline
\end{tabular}

The reaction mixture was placed in a $500 \mu 1$ reaction tube and covered with mineral oil in order to prevent evaporation of any component, or in a $200 \mu 1$ reaction tube without oil if the thermocycler had a hot cover. A standard PCR program is shown here:

$\begin{array}{lrll}\text { Initial denaturation } & 95^{\circ} \mathrm{C} & 5 \mathrm{~min} . & \\ 30-35 \text { cycles } & 94^{\circ} \mathrm{C} & 30 \mathrm{sec}-1 \mathrm{~min} & \text { (denaturation) } \\ & 55-64^{\circ} \mathrm{C} & 30 \mathrm{sec}-1 \mathrm{~min} & \text { (annealing) } \\ & 72^{\circ} \mathrm{C} & 1-2 \mathrm{~min} & \text { (extension) } \\ \text { Final extension } & 72^{\circ} \mathrm{C} & 10 \mathrm{~min} & \end{array}$




\subsubsection{Reverse Transcription PCR (RT-PCR)}

RT-PCR generates cDNA fragments from RNA templates and is very useful to determine the expression of genes in specific tissues or in different development stages. The „Titan ${ }^{\mathrm{TM}}$ One Tube RT-PCR-System“ (Roche, Penzberg) was always used in this work where a cDNA strand complementary to the RNA template was synthesized with the extension of a gene specific primer by the reverse transcriptase. After cDNA synthesis, the cDNA was used as template for a PCR reaction. This kit reduces the possibility of contamination due to a single reaction preparation. The master mix was prepared as follows:

\begin{tabular}{|c|c|}
\hline $22.4 \mu 1$ & Ampuwa $\mathrm{H}_{2} \mathrm{O}$ \\
\hline $8 \mu 1$ & 5x RTPCR buffer \\
\hline $2.5 \mu \mathrm{l}$ & DTT (100 mM) \\
\hline $1 \mu l$ & dNTPs (10 mM) \\
\hline $1 \mu l$ & Gene specific forward primer $(10 \mathrm{pmol} / \mu \mathrm{l})$ \\
\hline $1 \mu l$ & Gene specific reverse primer $(10 \mathrm{pmol} / \mu \mathrm{l})$ \\
\hline $1 \mu l$ & GAPDH forward primer* $(10 \mathrm{pmol} / \mu \mathrm{l})$ \\
\hline $1 \mu l$ & GAPDH reverse primer* (10 pmol/ $\mu \mathrm{l})$ \\
\hline $1 \mu l$ & RNase inhibitor $(40 \mathrm{U} / \mu \mathrm{l})$ \\
\hline $1 \mu 1$ & template RNA (1-4 $\mu \mathrm{g} / \mu 1$ total RNA) \\
\hline $0.6 \mu 1$ & Titan enzyme mix \\
\hline $40 \mu \mathrm{l}$ & Total volume \\
\hline
\end{tabular}

*= These primers are specific for the glycerin aldehyde phosphate dehydrogenase, which is expressed ubiquitously and functioned as a control for the RNA integrity. They were used for most of the RT-PCR experiments.

The program was as follows:

$\begin{array}{lcc}\text { Reverse transcription } & 50^{\circ} \mathrm{C} & 30 \mathrm{~min} \\ \text { Initial denaturation } & 94^{\circ} \mathrm{C} & 2 \mathrm{~min} \\ 10 \text { cycles: } & 94^{\circ} \mathrm{C} & 30 \mathrm{sec} \\ & 60^{\circ} \mathrm{C} & 1 \mathrm{~min} \\ & 68^{\circ} \mathrm{C} & 1 \mathrm{~min} \\ 25 \text { cycles: } & 94^{\circ} \mathrm{C} & 30 \mathrm{sec} \\ & 60^{\circ} \mathrm{C} & 1 \mathrm{~min} \\ & 68^{\circ} \mathrm{C} & 1 \mathrm{~min}+5 \mathrm{~s} \text { extra } \\ \text { Final extension } & 68^{\circ} \mathrm{C} & 7 \mathrm{~min}\end{array}$

After finishing the PCR program, the samples were analyzed by loading on a $0.8-2 \%$ agarose gel. 


\subsubsection{DNA Sequencing}

The sequencing method was derived from Sanger et al. (1977) where 4 different fluorescently marked ddNTPs (didesoxynucleosid-5'-triphosphate) were used. The sequence reaction was:

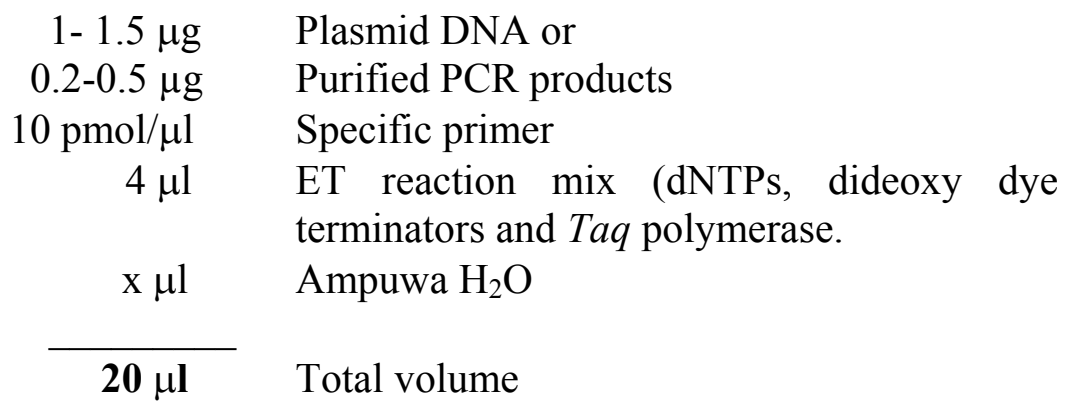

Elongation and chain termination took place in a thermocycler (MWG). The following sequence PCR program was used:

$\begin{array}{llr}\text { Initial denaturation } & 98^{\circ} \mathrm{C} & 5 \mathrm{~min} \\ 25 \text { cycles } & 98^{\circ} \mathrm{C} & 30 \mathrm{sec} \\ & 50^{\circ} \mathrm{C} & 15 \mathrm{sec} \\ & 60^{\circ} \mathrm{C} & 4 \mathrm{~min}\end{array}$

After PCR, the amplified DNA was precipitated by adding 3 vol 100\% ethanol and 0.1 vol $3 \mathrm{M} \mathrm{NaAc}, \mathrm{pH} 4.8$, and the samples were centrifuged at $13,000 \mathrm{x}$ g for 30 min at $4^{\circ} \mathrm{C}$ and dried.

\subsection{Gel Electrophoresis for Separation of Nucleic Acids}

\subsubsection{DNA Horizontal Electrophoresis in Agarose Gels}

The DNA fragments were electrophoretically separated according to their molecular size in agarose gels $(0.6 \%-2 \%)$. The agarose was shortly (2-3 min) boiled in $0.5 \mathrm{x}$ TBE and after cooling down $\left(\sim 60^{\circ} \mathrm{C}\right), 5 \mu \mathrm{l}$ ethidium bromide $(5 \mathrm{mg} / \mathrm{ml})$ per $100 \mathrm{ml}$ gel were added and poured in a gel caster. The same buffer was used as electrophoresis buffer. Before loading the samples, $0.2-0.5 \mathrm{vol}$ loading buffer was added and mixed. The samples were then loaded into the wells of the gel and electrophoresis was carried out at a steady voltage $\left(100-150 \mathrm{~V}\right.$ or $\left.3-4 \mathrm{~V} / \mathrm{cm}^{2}\right)$. Under this condition, the DNA moves towards the cathode. The DNA fragments were observed and photographed under UV light at a $\lambda$ of 
$254 \mathrm{~nm}$ or $312 \mathrm{~nm}$ due to the intercalation of the fluorescent dye ethidium bromide into the double chain of DNA.

\subsubsection{DNA Vertical Electrophoresis in Agarose Gels}

Restricted genomic DNA was separated in vertical chambers for gel electrophoresis (Glasgerätebau Ochs, Bovenden/Lenglern) with 1x E buffer as gel and running buffer. The lower anode chamber opening was sealed with a $2 \%$ agarose ground gel. After gelification, a $0.8-1.3 \%$ running agarose gel was poured. The DNA samples were mixed with $20 \%(\mathrm{v} / \mathrm{v})$ loading buffer and run at $15 \mathrm{~V}$ overnight. Finally, the gel was photographed under UV light (254 nm) and transferred to a membrane (2.10.1.).

$\begin{array}{llll}\text { 10x E Buffer: } & \mathrm{NaH}_{2} \mathrm{PO}_{4} & \\ & 300 \mathrm{mM} & \mathrm{Na}_{2} \mathrm{HPO}_{4} & \\ 267 \mathrm{mM} & \text { EDTA } & \\ 50 \mathrm{mM} & \text { pH 7.3-7.4 } & \text { with } \mathrm{NaOH}\end{array}$

\subsubsection{RNA Electrophoresis in Denaturing Agarose Gels}

For the separation of RNA by electrophoresis, denaturing vertical agarose gels were employed to avoid the secondary structures formed in RNA due to hydrogen bonds. Before use, the chambers were treated with RNase ZAP (Ambion, Wiesbaden) to eliminate RNase, and finally rinsed with $\mathrm{dH}_{2} \mathrm{O}$. The gel was prepared by boiling $1.5 \mathrm{~g}$ agarose with $87.5 \mathrm{ml}$ DEPC- $\mathrm{H}_{2} \mathrm{O}$ and $12.5 \mathrm{ml} 10 \mathrm{x}$ E buffer, until complete solution. After cooling of the gel to approximately $50^{\circ} \mathrm{C}, 25 \mathrm{ml}$ of $37 \%$ formaldehyde was added and was immediately poured into a vertical gel bed (RNase free). Before loading, the RNA samples were mixed with the following:

$\begin{array}{ccc} & 2 \mu \mathrm{l} & 10 \mathrm{x} \text { E buffer } \\ & 3 \mu \mathrm{l} & 37 \% \text { Formaldehyde } \\ 8 \mu \mathrm{l} & & \text { Formamide } \\ & 20 \mu \mathrm{g} & \text { RNA } \\ & \mathrm{x} \mu \mathrm{l} & \text { DEPC } \mathrm{H}_{2} \mathrm{O}\end{array}$

The mixture was denatured at $65^{\circ} \mathrm{C}$ for $10 \mathrm{~min}$ then cooled on ice. $16 \mu 1$ stop mix that contained $0.2 \mu \mathrm{g}$ ethidium bromide were added and the samples were loaded into the gel wells. Electrophoresis was carried out at $6.5 \mathrm{~V} / \mathrm{cm}^{2}$ at $4^{\circ} \mathrm{C}$ or at $4 \mathrm{~V} / \mathrm{cm}^{2}$ at room temperature (RT) with 1x E buffer until the blue dye of the loading buffer reached the 
front of the gel. The agarose gel was photographed under UV light $(254 \mathrm{~nm})$ and the RNA was transferred to a membrane (2.10.2).

\subsubsection{SDS-Polyacrylamide (PAA) Gel}

PAA gels from $10-15 \%$ were used to separate protein mixtures according to their different molecular weights. Before electrophoretic separation, the proteins were prepared as follows. Tissues were homogenized in an appropriate buffer mechanically and/or by ultrasound handling $(1 \mathrm{~min})$. The supernatants were mixed with 1 vol 2x SDS-loading buffer, denatured by boiling $10 \mathrm{~min}$ and centrifuged $2 \mathrm{~min}$ at full speed. Finally, the samples were cooled, handled again with ultrasound and centrifuged $5 \min (13,000 \mathrm{x} g)$ to pellet the unsolved material. Normally, $10 \mu \mathrm{l}$ of the sample were loaded into a gel well. To prepare SDS-PAA gels, the components for the separating gel listed in the table were mixed together and poured between the ethanol rinsed glass plates. The separating gel was covered with some $\mathrm{dH}_{2} \mathrm{O}$ and let at least 20 min to polymerize. Then, the water was removed and the collecting gel was prepared according to the table, mixed and poured over the separation gel. The gel comb was laid avoiding air bubbles. After the polymerization, the gel was attached to the electrophoresis chamber and covered with electrophoresis buffer. The electrophoresis was carried out for $1.5-5 \mathrm{~h}$ at $45 \mathrm{~mA}$ according to the size of the gel.

\begin{tabular}{|c|c|c|c|}
\hline SEPARATION GEL & $\mathbf{1 0 \%}$ & $\mathbf{1 2 \%}$ & $\mathbf{1 5 \%}$ \\
\hline Acrylamide 29:1 (40\%) & $5 \mathrm{ml}$ & $6 \mathrm{ml}$ & $7 \mathrm{ml}$ \\
Lower Tris & $5 \mathrm{ml}$ & $5 \mathrm{ml}$ & $5 \mathrm{ml}$ \\
dH $_{2}$ O & $10 \mathrm{ml}$ & $9 \mathrm{ml}$ & $8 \mathrm{ml}$ \\
SDS 10\% & $100 \mu \mathrm{l}$ & $100 \mu \mathrm{l}$ & $100 \mu \mathrm{l}$ \\
APS 10\% & $200 \mu \mathrm{l}$ & $200 \mu \mathrm{l}$ & $200 \mu \mathrm{l}$ \\
TEMED & $6 \mu \mathrm{l}$ & $6 \mu \mathrm{l}$ & $6 \mu \mathrm{l}$ \\
\hline
\end{tabular}

\begin{tabular}{|c|c|}
\hline COLLECTING GEL & $\mathbf{3 \%}$ \\
\hline Acrylamide 29:1 (40\%) & $1.3 \mathrm{ml}$ \\
Upper Tris & $1.3 \mathrm{ml}$ \\
dHo & $7.4 \mathrm{ml}$ \\
SDS 10\% & $50 \mu l$ \\
APS 10\% & $50 \mu 1$ \\
TEMED & $6 \mu \mathrm{l}$ \\
\hline
\end{tabular}


Electrophoresis buffer:

Acrylamide 29:1 (40\%):

Lower Tris:

Upper Tris:

2x SDS Loading Buffer:

$$
\begin{array}{ll}
1.44 \%(\mathrm{w} / \mathrm{v}) & \text { Glycine } \\
0.3 \%(\mathrm{w} / \mathrm{v}) & \text { Tris base } \\
0.1 \%(\mathrm{w} / \mathrm{v}) & \text { SDS }
\end{array}
$$

$38.6 \%(\mathrm{w} / \mathrm{v}) \quad$ Acrylamide

$1.4 \%(\mathrm{w} / \mathrm{v}) \quad$ Bis-acrylamide

$\begin{array}{ll}1.5 \mathrm{M} & \text { Tris/HCl, } \mathrm{pH} 8.8 \\ 0.4 \%(\mathrm{w} / \mathrm{v}) & \mathrm{SDS}\end{array}$

$\begin{array}{ll}0.5 \mathrm{M} & \text { Tris/HCl, } \mathrm{pH} 6.8 \\ 0.4 \%(\mathrm{w} / \mathrm{v}) & \text { SDS }\end{array}$

$$
\begin{array}{cl}
4.8 \%(\mathrm{w} / \mathrm{v}) & \text { SDS } \\
20 \%(\mathrm{v} / \mathrm{v}) & \text { Glycerin } \\
10 \%(\mathrm{v} / \mathrm{v}) & \beta \text {-Mercapto-ethanol } \\
0.1 \%(\mathrm{w} / \mathrm{v}) & \text { Bromphenol blue } \\
100 \mathrm{mM} & \text { Tris/HCl, } \mathrm{pH} 7.8
\end{array}
$$

\subsubsection{PAA Gels Staining.}

The PAA gels were stained with Coomassie Brilliant Blue 250. After the electrophoresis, the gel was introduced into the staining solution from $1 \mathrm{~h}$ to overnight. To detect clearly the protein bands, the gel was incubated in a decolouring solution overnight under rocking. Alternatively, the „Simply Blue ${ }^{\mathrm{TM}}$ SafeStain“ (Invitrogen, Groningen) staining solution was used to dye the protein PAA gel. The PAA gel was rinsed 3x for 5 min with $\mathrm{dH}_{2} \mathrm{O}$. Then, it was covered with SimplyBlue ${ }^{\mathrm{TM}}$ solution and stained for $1 \mathrm{~h}$ at RT under gentle shaking. The staining solution was discarded and the gel was washed with $\mathrm{dH}_{2} \mathrm{O}$ for $1 \mathrm{~h}$. A second water wash was required for a clear gel background.

Staining solution:

Decolouring solution:

$\begin{array}{clll}30 \%(\mathrm{v} / \mathrm{v}) & \text { Methanol } & & \\ 10 \%(\mathrm{v} / \mathrm{v}) & \text { Acetic acid } & & \\ 0.2 \%(\mathrm{w} / \mathrm{v}) & \text { Coomassie Brilliant Blue } \\ & \text { R250 }\end{array}$

30\% (v/v) Methanol

$10 \%(\mathrm{v} / \mathrm{v}) \quad$ Acetic acid 


\subsection{Blotting Techniques}

\subsubsection{Southern Blotting}

The Southern blot procedure refers to different sizes of denatured DNA molecules that are transferred from agarose gels onto a solid support such as nitrocellulose membranes (Hybond C, Amersham, Braunschweig) or nylon membranes (Hybond N, Amersham, Braunschweig) through the diffusion of salt solutions by capillarity. This membranes are then hybridized with a labeled DNA probe (Southern, 1974).

Horizontal or vertical agarose gel electrophoresis (2.9.1., 2.9.2.) were used for the separation of DNA fragments. After electrophoresis, the gel was shaken twice for $20 \mathrm{~min}$ in denaturating solution and then twice for $20 \mathrm{~min}$ in neutralisation solution. Then, the gel

was placed on 20x SSC soaked Whatman paper which ends are sank in a recipient with 20x SSC. The membrane was placed directly on the gel and covered by a layer of $2 x$ SSC soaked Whatman paper gel. The air bubbles were eliminated using a roller on the Whatman paper. More dry paper was placed on the wet Whatman paper and finally an object 200-500 g was placed on top. Then, the transfer was allowed to occur overnight at RT. After that, the membrane was soaked in 2x SSC and the DNA was fixed onto it either by baking for $2 \mathrm{~h}$, at $80^{\circ} \mathrm{C}$ or by UV cross-linking (120 mJ; UV Stratalinker TM 1800, Stratagene, Heidelberg).

Alternatively, a Turboblotter ${ }^{\mathrm{TM}}$ (Schleicher \& Schuell, Dassel) was used to transfer the genomic DNA. There, 20 pieces of dry gel-sized Whatman paper (Schleicher \& Schuell, GB004) were used, followed by 4 pieces of GB002 Whatman paper and the 2x SSC wet membrane. Then comes the gel, 3 pieces of 20x SSC wet GB002 and a GB004 paper bridge soaked in 20x SSC and in contact with a channel filled with 20x SSC.

\subsubsection{Northern Blotting}

Northern blot hybridisation is a procedure by which different sized RNA molecules are separated in a denaturating agarose gel (2.9.3.), transferred onto a solid support of nitrocellulose or nylon membrane and then subjected to hybridisation with a labeled DNA or RNA probe. 
The same procedure was used as described in the Southern blot. However, in this case the gel was not denatured and the RNA was transferred directly onto the membrane using 20x SSPE as transfer buffer, prepared with DEPC treated $\mathrm{H}_{2} \mathrm{O}$. The membrane stripe where the RNA standard is transferred is cut out and shaked gently with 5\% acetic acid for $15 \mathrm{~min}$ and then dyed $10 \mathrm{~min}$ in methylene blue solution $(0.04 \%$ in $0.5 \mathrm{M} \mathrm{NaAc}, \mathrm{pH}$ 5.2). The exceeding methylene blue is eliminated by rinsing with $\mathrm{H}_{2} \mathrm{O}$ until the blue dyed RNA bands become visible.

20x SSPE

$\begin{array}{rl}174 \mathrm{~g} & \mathrm{NaCl} \\ 27.6 \mathrm{~g} & \mathrm{NaH}_{2} \mathrm{PO}_{4} \\ 7.4 \mathrm{~g} & \text { EDTA } \\ & \text { pH 7.4 }\end{array}$

\subsubsection{Colony Transfer and Hybridisation}

The colony hybridisation is a rapid and effective technique that detects recombinant sequences isolated directly from cells grown on plates and transferred to membranes. 88 mm $\phi$ nitrocellulose or nylon membranes (Optitran BA-S85, Schleicher \& Schuell) were placed on the plates for 1-2 min to transfer the colonies to the filters, whereas reference position points were marked to identify later the positive colonies. The culture plate was incubated at $37^{\circ} \mathrm{C}$, so the colonies grow again. The marked membranes were placed on surfaces with the following solutions:

$\begin{array}{rl}5 \mathrm{~min} & 10 \%(\mathrm{w} / \mathrm{v}) \mathrm{SDS} \\ 3 \mathrm{~min} & \text { Denaturation solution } \\ 10 \mathrm{~min} & \text { Neutralisation solution } \\ 10 \mathrm{~min} & 2 \mathrm{xSSC}\end{array}$

DNA was fixed by UV cross-linking. Then the membrane was ready for hybridisation with a ${ }^{32}$ P-labeled probe (2.11.1.). After hybridisation, the positive colonies were localized.

\subsection{Labeling of Nucleic Acids}

\subsubsection{Radioactive Labeling of Nucleic Acids}

To detect specific nucleic acid sequences in Northern and Southern blot filters, DNA probes were ${ }^{32} \mathrm{P}$ labeled with the Hexalabel ${ }^{\mathrm{TM}}$ DNA labeling kit (MBI Fermentas, St. Leon-Rot). DNA (30-40 ng) was mixed with $10 \mu \mathrm{l} 5 \mathrm{x}$ reaction buffer and filled with 
Ampuwa $\mathrm{H}_{2} \mathrm{O}$ to a final volume of $40 \mu$ l. This reaction was vortexed and denatured at $95^{\circ} \mathrm{C}$ for 10 min together and then placed on ice. After cooling down, $3 \mu 1$ Mix $\mathrm{C}$ (without $\mathrm{dCTP}\left[{ }^{32} \mathrm{P}\right]$ ) were added. The reaction was transferred to the isotope laboratory, where $1 \mu \mathrm{l}$ Klenow enzyme and $30-40 \mu \mathrm{Ci} \alpha-\left[{ }^{32} \mathrm{P}\right] \mathrm{dCTP}$ were added. The reaction was incubated at $37^{\circ} \mathrm{C}$ for $10 \mathrm{~min}$ after which $4 \mu \mathrm{dNTPs}$ were added and incubated for further 5 min. The reaction was stopped with $1 \mu 10.5 \mathrm{M}$ EDTA, $\mathrm{pH}$ 8.0. The already labeled DNA was purified using MicroSpin ${ }^{\mathrm{TM}}$ S-200 HR columns (Amersham, Braunschweig) by adding $150 \mu \mathrm{H}_{2} \mathrm{O}$ and centrifuging at 3,000x g for $2 \mathrm{~min}$. The liquid resulting from the centrifugation was denatured at $95^{\circ} \mathrm{C}$ for $10 \mathrm{~min}$ and placed on ice for $2 \mathrm{~min}$. Then, the probe was added to the hybridisation tube.

\subsubsection{Digoxygenin labeling}

The digoxygenin DNA labeling was done following the protocol of the,,DIG DNA labeling Kit" (Roche, Penzberg). The labeled DNA fragment was purified by a phenol/chloroform extraction followed by an ethanol precipitation. The digoxygenin labeled DNA fragment can be stored at $-20^{\circ} \mathrm{C}$ until 1 year. The DIG-labeling efficiency was checked by the procedure described in 2.12.4.

\subsection{3. in vitro Transcription}

The „DIG RNA labeling Kit“ (Roche, Penzberg) was used for the production of in vitro transcripts, where the plasmid DNA was linearized and purified for the in vitro transcription. To check the synthesis of complete transcripts, a $1 \mu 1$ aliquot was run in a $1 \%$ agarose gel. The RNA was purified according to the company's protocol, solved in $100 \mu \mathrm{DEPC} \mathrm{H}_{2} \mathrm{O}$ and stored at $-20^{\circ} \mathrm{C}$ until its use. The labeling efficiency was checked by an immunological assay (2.12.4.). The in vitro transcription was done for $1 \mathrm{~h}$ at $37^{\circ} \mathrm{C}$ in a $20 \mu \mathrm{l}$ reaction as follows:

$\begin{array}{ccc}2 \mu \mathrm{l} & 1 \mu \mathrm{g} & \begin{array}{l}\text { Linearized DNA template } \\ \text { DIG RNA labeling mix } \\ 2 \mu \mathrm{l}\end{array} \\ 1 \mu \mathrm{l} & \text { 10x transcription buffer } \\ 1 \mu \mathrm{l} & \text { RNase inhibitor }(\text { RNasin, } 28 \mathrm{U} / \mu \mathrm{l}) \\ \mathrm{x} \mu \mathrm{l} & \text { RNA polymerase }(10 \mathrm{U} / \mu \mathrm{l}) \\ & \text { DEPC } \mathrm{H}_{2} \mathrm{O}\end{array}$




\section{$\mathbf{2 0} \mu \mathbf{l} \quad$ Total volume}

\subsection{Hybridisation Methods}

\subsubsection{Hybridisation of 32P-Labeled DNA with Northern or Southern Membranes.}

The blotted nitrocellulose or nylon filters containing either DNA or RNA (2.10.1. 2.10.2.) were rolled and placed into a hybridisation tube (nucleic acid facing inwards), which was filled with 2x SSC and freed from air bubbles. Once the filters were placed, the 2x SSC was poured out and replaced with $15 \mathrm{ml}$ pre-warmed $\left(65^{\circ} \mathrm{C}\right)$ hybridisation solution and $500 \mu \mathrm{l}$ denatured $\left(95^{\circ} \mathrm{C}, 10 \mathrm{~min}\right)$ salmon sperm DNA. The tubes were then pre-hybridised for 2-3 hrs in a rotation oven at $65^{\circ} \mathrm{C}$. Then, the denatured radioactive probe (2.11.1) was added to the tube and the hybridisation was carried out overnight under the same conditions as the pre-hybridisation.

At the next day, the hybridisation solution was poured out and the filters were washed at $65^{\circ} \mathrm{C}$ with the washing solution 1 for 5-20 min, depending on the activity shown by the filters. The radioactive signals were checked with a hand monitor ( $\beta$ and $\gamma$ detector, $122 \mathrm{LB}$, Berthold). A second wash with the washing solution 2 was done for 5-10 $\mathrm{min}$ if the filter showed an activity of $>2 \mathrm{~Bq} / \mathrm{cm}^{2}$. Finally, the filters were wrapped into plastic folio and exposed to an x-ray film in an autoradiography cassette, which was placed at $80^{\circ} \mathrm{C}$ overnight.

$\begin{array}{lcl}\text { Hybridisation solution: } & 5 \mathrm{x} & \mathrm{SSC} \\ & 5 \mathrm{x} & \text { Denhardt's solution } \\ & 10 \%(\mathrm{w} / \mathrm{v}) & \text { Dextran sulfate } \\ & 0.5 \%(\mathrm{w} / \mathrm{v}) & \mathrm{SDS} \\ & & \\ \text { Washing solution 1: } & 2 \mathrm{x} & \mathrm{SSC} \\ & 0.1 \%(\mathrm{w} / \mathrm{v}) & \mathrm{SDS} \\ & & \\ \text { Washing solution 2: } & 0.2 \mathrm{x} & \mathrm{SSC} \\ & 0.1 \%(\mathrm{w} / \mathrm{v}) & \mathrm{SDS}\end{array}$

\subsubsection{Screening of Mouse Filter Libraries}

Both mouse testes cDNA library (3 filters) and mouse cosmid library (11 filters) were screened with random ${ }^{32} \mathrm{P}$-labeled gene specific probes to isolate the complete cDNA and 
the mouse genomic homologue of the gene in subject, respectively. The hybridisation was done in a recipient appropriate for the size of the filters, where the filters were introduced with enough hybridisation solution to cover them. The pre-hybridisation was done with $1 \mathrm{ml}$ denatured $\left(95^{\circ} \mathrm{C}, 5 \mathrm{~min}\right)$ salmon sperm DNA and $500 \mathrm{ml}$ hybridisation solution pre-warmed to $65^{\circ} \mathrm{C}$ for $30 \mathrm{~min}$. Then, the ${ }^{32} \mathrm{P}$-labeled probe was added and the hybridisation was done at this temperature overnight. At the next day the filters were rinsed shortly with the washing solution 3 and were sealed wet into plastic sheets. Then, the filters were exposed to an x-ray film in an autoradiography cassette and placed at -80 ${ }^{\circ} \mathrm{C}$ overnight.

\begin{tabular}{|c|c|c|}
\hline 1 M Na Phosphate sol: & $\begin{array}{l}316 \mathrm{ml} \\
684 \mathrm{ml}\end{array}$ & $\begin{array}{l}1 \mathrm{M} \mathrm{NaH}_{2} \mathrm{PO}_{4} \\
1 \mathrm{M} \mathrm{Na}_{2} \mathrm{HPO}_{4}, \mathrm{pH} 7.2\end{array}$ \\
\hline Hybridisation buffer: & $\begin{array}{c}0.5 \mathrm{M} \\
7 \% \\
1 \mathrm{mM}\end{array}$ & $\begin{array}{l}\text { Na Phosphate sol, pH } 7.2 \\
\text { SDS } \\
\text { EDTA }\end{array}$ \\
\hline Washing solution 3: & $\begin{array}{l}40 \mathrm{mM} \\
0.1 \%\end{array}$ & $\begin{array}{l}\text { Na Phosphate sol, pH } 7.2 \\
\text { SDS }\end{array}$ \\
\hline
\end{tabular}

\subsubsection{Hybridisation of DIG-labeled DNA Probes}

The pre-hybridisation was done at the hybridisation temperature (generally $68^{\circ} \mathrm{C}$ ) for $3-4$ $\mathrm{h}$ in the hybridisation solution without the probe. The hybridisation was performed overnight at the same temperature after the addition of the denatured probe at a concentration of $5-25 \mathrm{ng} / \mathrm{ml}$. After the hybridisation, some washing steps were done in the following order:

$\begin{array}{rll}15 \mathrm{~min} & \text { Washing solution } 1 & \text { RT (2.12.1.) } \\ 1 \mathrm{~min} & \text { Washing solution } 1 & 65^{\circ} \mathrm{C} \\ 10 \mathrm{~min} & \text { Washing solution } 4 & 65^{\circ} \mathrm{C}\end{array}$

$\begin{array}{lcl}\text { DIG-Hyb. solution: } & 5 \mathrm{x} & \text { SSC } \\ & 1 \%(\mathrm{w} / \mathrm{v}) & \text { Blocking reagent } \\ & 0.1 \%(\mathrm{w} / \mathrm{v}) & \text { N-Lauryl sarcosin } \\ & 0.02 \%(\mathrm{w} / \mathrm{v}) & \text { SDS }\end{array}$

Washing solution 4: $\quad 0.1 \mathrm{x} \quad$ SSC 


\subsubsection{Digoxygenin Signal Detection}

The detection of DNA or RNA by digoxygenin-labeled probes was done in two ways: by the dephosphorylation of the chemical substrate CSPD (Roche, Penzberg) for filters that are used multiple times, or by the color reaction with BCIP/NBT for filter used just one time. The reaction was catalyzed by a specific anti-DIG antibody coupled with alkaline phosphatase, and unstable light (with CSPD) or color intermediate (BCIP/NBT) were obtained. The incubation steps were done at RT in an orbital shaker. The membrane was equilibrated with buffer $1 \mathrm{~A}$ for $5 \mathrm{~min}$ after the washing steps (2.12.3.). To block unspecific binding sites, the membrane was washed in buffer 2 for $30 \mathrm{~min}$. Next, the membrane was incubated 30-60 min with the antibody conjugate $(1: 10,000$, in buffer 2$)$ inside sealed plastic sheets. To eliminate not bound antibodies, the membrane was washed in buffer $1 \mathrm{~A}$ twice for $15 \mathrm{~min}$. After a $5 \mathrm{~min}$ washing step in buffer 3 to remove buffers, the membrane was incubated with $15 \mathrm{ml}$ CSPD solution $(1: 1000$ in buffer 3$)$ in the dark for 5 min or with a BCIP/NBT color solution until color appears.

\begin{tabular}{|c|c|c|}
\hline Buffer 1A: & $\begin{array}{l}50 \mathrm{mM} \\
75 \mathrm{mM} \\
0.3 \%(\mathrm{w} / \mathrm{v})\end{array}$ & $\begin{array}{l}\text { Maleic acid, pH } 7.5 \\
\mathrm{NaCl} \\
\text { Tween } 20\end{array}$ \\
\hline Buffer 2: & $1 \%(\mathrm{w} / \mathrm{v})$ & Blocking reag. in buffer 1 \\
\hline Buffer 3: & $\begin{array}{r}100 \mathrm{mM} \\
50 \mathrm{mM} \\
100 \mathrm{mM}\end{array}$ & $\begin{array}{l}\mathrm{NaCl} \\
\mathrm{MgCl}_{2} \\
\text { Tris/HCl, pH } 9.5\end{array}$ \\
\hline NBT solution: & $\begin{array}{l}75 \mathrm{mg} / \mathrm{ml} \\
70 \%\end{array}$ & $\begin{array}{l}\text { NBT } \\
\text { Dimethylformamide (DMF) }\end{array}$ \\
\hline BCIP solution: & $50 \mathrm{mg} / \mathrm{ml}$ & BCIP in DMF \\
\hline Color solution: & $\begin{array}{l}45 \mu \mathrm{l} \\
35 \mu \mathrm{l} \\
10 \mathrm{ml}\end{array}$ & $\begin{array}{l}\text { NBT solution } \\
\text { BCIP solution } \\
\text { Buffer } 3\end{array}$ \\
\hline
\end{tabular}




\subsection{In situ Hybridisation Techniques.}

\subsubsection{Pre-treatment of the Glass Slides}

The glass slides were coated with organosilan so that the paraffin sections have a better adhesion on them. The slides were sterilized boiling with $0.1 \mathrm{~N} \mathrm{HCl}$ and the resulting sterile slides were incubated in 1x Denhardt's solution overnight. Later, they were fixed with ethanol/acetic acid (3:1) for $20 \mathrm{~min}$. Then, rehydratation of the slides was performed in a decreasing series of ethanol $(96 \%, 70 \%, 50 \%, 30 \%)$ each for $5 \mathrm{~min}$. The slides were then incubated overnight in $1 \%$ organosilan solution at $70^{\circ} \mathrm{C}$ and they were washed several times with $\mathrm{dH}_{2} \mathrm{O}$. Next, they were baked at $100^{\circ} \mathrm{C}$ for several hours. In this condition, the slides can be stored until 6 months at $4^{\circ} \mathrm{C}$. The slides were activated in buffered glutaraldehyde for $30 \mathrm{~min}$ for a better adhesive power. After the glutaraldehyde was rinsed for $5 \mathrm{~min}$ in $\mathrm{dH}_{2} \mathrm{O}$, the activation was stabilized in $0.1 \mathrm{M}$ Sodium-m-periodate solution for $15 \mathrm{~min}$. After this, the slides were rinsed $3 \mathrm{x}$ for $5 \mathrm{~min}$ in $1 \mathrm{x}$ PBS and dried at $42^{\circ} \mathrm{C}$. The activated slides can be used in 8 weeks and should be stored at $4^{\circ} \mathrm{C}$.
Organosilan: $\quad 1 \%(\mathrm{v} / \mathrm{v}) \quad \gamma$-aminopropyltrithoxysilane pH 3.45

Buffered Glutaraldehyde: $10 \%$

Glutaraldehyde in 1x PBS, pH 7.0

\subsubsection{Preparation of Paraffin Sections}

Testes were placed in $10 \%$ buffered formaldehyde and fixed overnight to begin the paraffin embedding procedure. Then, the tissues were dehydrated for $1 \mathrm{~h}$ each in an increasing series of ethanol $(50 \%, 70 \%, 90 \%, 96 \%)$. For the paraffin embedding, the alcohol must be removed from the tissue, which was achieved with an overnight incubation in methyl benzoate. Washing twice for $10 \mathrm{~min}$ with Roticlear, the methyl benzoate was also removed. The embedding was done with a paraffin mixture with the commercial name of Paraplast ${ }^{\mathrm{TM}}$, which contains DMSO for a better infiltration in the tissue. The jars used in the procedure are temperated at $60^{\circ} \mathrm{C}$. The Paraplast ${ }^{\mathrm{TM}}$ was melt at $60^{\circ} \mathrm{C}$ in an oven for $1 \mathrm{~h}$. The Roticlear was replaced with 1:1 Roticlear and 
Paraplast ${ }^{\mathrm{TM}}$, and the tissue was incubated at $60^{\circ} \mathrm{C}$ in this medium twice for $20 \mathrm{~min}$. Then, the tissue was incubated $2 \times 20$ min in Paraplast ${ }^{\mathrm{TM}}$ alone. The tissue was transferred to the embedding mould, which was filled with liquid Paraplast ${ }^{\mathrm{TM}}$ and laid at RT to solidify. After this, the paraffin block was cut and mounted onto the microtome (HN 40 Ing, Nussloch) to make sections of 2-10 $\mu \mathrm{m}$. The sections were mounted on pre-treated slides with the help of a $70 \%$ ethanol drop at $42^{\circ} \mathrm{C}$ and laid at this temperature until the liquid evaporates. The paraffin sections were then stored at $4{ }^{\circ} \mathrm{C}$.

Buffered Formaldehyde: $\quad 10 \% \quad$ Formaldehyde in 1x PBS

\subsection{3. in situ Hybridisation of Tissue Sections}

The tissue sections were incubated twice for $10 \mathrm{~min}$ in Roticlear to remove paraffin. Then, the sections were re-hydrated in a decreasing ethanol series $(100 \%, 96 \%, 70 \%$, $50 \%, 30 \%$ ) for 2 min each followed by:

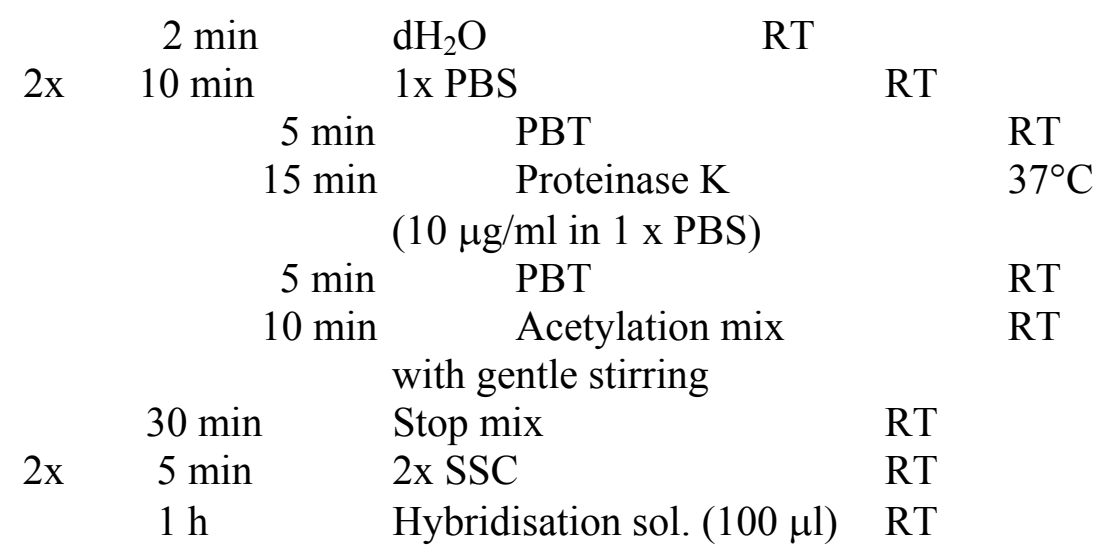

For the hybridisation, $2 \mu$ denatured DIG-RNA probe (2.11.3.) in $100 \mu$ l hybridisation solution (avoiding bubbles) were added to the slides and covered with a slide cover, and were incubated overnight at $37^{\circ} \mathrm{C}$ in a wet chamber (with filter paper soaked in $50 \%$ formamide/4x SSC). After hybridisation, the cover slides were removed by immersing the preparations in 2x SSC for $30 \mathrm{~min}$. Non-specifically bound probe was removed by the following wash steps:

$\begin{array}{rrr}30 \mathrm{~min} & 50 \%(\mathrm{v} / \mathrm{v}) \text { Formamide } / 2 \times \mathrm{SSC} & \mathrm{RT} \\ 15 \mathrm{~min} & 50 \%(\mathrm{v} / \mathrm{v}) \text { Formamide } / 2 \times \mathrm{SSC} & 50^{\circ} \mathrm{C} \\ 15 \mathrm{~min} & \mathrm{RT} & \\ 5 \mathrm{~min} & \mathrm{PBT} & \mathrm{RT}\end{array}$




\begin{tabular}{|c|c|c|}
\hline Acetylation Mix: & $\begin{array}{r}0.5 \mathrm{ml} \\
200 \mathrm{ml}\end{array}$ & $\begin{array}{l}\text { Anhydrous acetic acid } \\
0.1 \mathrm{M} \text { triethanolamine, } \\
\text { pH } 8.0, \text { mixed with high stirring }\end{array}$ \\
\hline Stop Mix: & $\begin{array}{l}0.1 \mathrm{M} \\
0.1 \mathrm{M}\end{array}$ & $\begin{array}{l}\text { Glycine } \\
\text { Tris/HCl, pH } 7.0\end{array}$ \\
\hline Hybridisation sol.: & $\begin{array}{c}0.25 \mathrm{mg} / \mathrm{ml} \\
0.5 \mathrm{mg} / \mathrm{ml} \\
4 \mathrm{x} \\
50 \%(\mathrm{v} / \mathrm{v}) \\
1 \mathrm{x} \\
5 \%(\mathrm{w} / \mathrm{v})\end{array}$ & $\begin{array}{l}\text { Yeast t-RNA } \\
\text { Salmon sperm DNA } \\
\text { SSC } \\
\text { Deionised Formamide } \\
\text { Denhardt's solution } \\
\text { Dextran sulfate }\end{array}$ \\
\hline
\end{tabular}

\subsubsection{Detection of DIG RNA Probes in situ}

The DIG probes are detected by an antibody coupled with the alkaline phosphatase, which recognizes the digoxygenin part of the probe. The samples followed the next procedure:

\begin{tabular}{|c|c|c|}
\hline $\mathrm{x}$ & Buffer 1B & $5 \mathrm{~min}$ \\
\hline $1 \mathrm{x}$ & $2 \%$ Goat normal serum in B2 (2.12.4.) & $30 \mathrm{~min}$ \\
\hline & $\begin{array}{l}\alpha \text {-Digoxygenin antibody (1:500 in } \mathrm{B} 2) \text {, } \\
100 \mu 1 / \text { sample in a damp chamber with } \mathrm{B} 1 \mathrm{E}\end{array}$ & $2 \mathrm{~h}$ \\
\hline & Buffer 1B & $10 \min$ \\
\hline & Buffer 3 (2.12.4.) & $2 \min$ \\
\hline
\end{tabular}

The color reaction was performed by covering the slides with $100 \mu \mathrm{l}$ of color solution until the desired color intensity was reached. Then, the reaction was stopped with Buffer 4. As long as the color reaction is sensitive to light and oxygen, it took place with a cover slide in the dark. The samples were then covered with a water medium like „Aqua Polymount $^{\mathrm{TM} \text { “ }}$ (Polysciences, PA, USA) for their permanent conservation, due to the impairment of the color with organic media.

$\begin{array}{lrl}\text { Buffer 1B: } & 150 \mathrm{mM} & \mathrm{NaCl} \\ & 100 \mathrm{mM} & \text { Tris/HCl, } \mathrm{pH} 7.5 \\ \text { Buffer 4: } & 1 \mathrm{mM} & \text { EDTA } \\ & 10 \mathrm{mM} & \text { Tris/HCl, } \mathrm{pH} 8.0\end{array}$

\subsection{Protein and Immunohistochemical Methods \\ 2.14.1. Isolation of Total Protein from Mouse Tissue}


PBS medium was added to the tissues and homogenization was done. After adding 1 vol 2x SDS loading buffer, the samples were handled with ultrasound on ice 2x 10 min. Then, the proteins were denatured $10 \mathrm{~min}$ in boiling water and cooled on ice. The samples were handled with ultrasound again and the big tissue pieces were pelleted for 5 min at 13,000x g. $10 \mu \mathrm{l}$ of the supernatant were separated in an SDS-PAA gel (2.9.4.) after mixing with 1 vol 2x SDS loading buffer and the samples were stored at $-20^{\circ} \mathrm{C}$.

\subsubsection{Coupling of the Synthetic Peptide to BSA}

$20 \mathrm{mg}$ BSA $(\sim 0.3 \mu \mathrm{mol})$ were solved in $0.5 \mathrm{ml} 0.4 \mathrm{M}$ PBS, pH 7.5. Also, $10 \mu \mathrm{mol}$ of the synthetic peptide were solved in $1.5 \mathrm{ml}$ Ampuwa $\mathrm{H}_{2} \mathrm{O}$ and the $\mathrm{pH}$ adjusted to 7.5. The solutions of BSA and peptide were mixed and added drop by drop during 5 min to a $1 \mathrm{ml}$ solution of glutaraldehyde in $\mathrm{dH}_{2} \mathrm{O}$ (end concentration of $10 \mu \mathrm{M}$ ) under permanent stirring. The mixture was stirred for further $30 \mathrm{~min}$. The glutaraldehyde that was not incorporated was inactivated by adding 0.1 vol $1 \mathrm{M}$ glycine solution and the sample was stirred for 30 min more and finally dialyzed against PBS.

\subsubsection{Isolation of Polyclonal Monospecific Antibodies}

For the isolation of specific antibodies, a peptide with a partial Hook1 amino acid sequence was synthesized (Interactiva, Ulm) with the following sequence:

\section{N-term-RKQLAEKERRIEILESECKV-C-term.}

This peptide was used to generate polyclonal antiserum in New Zealand rabbits: The New Zealand rabbits were immunized with $\sim 1 \mu$ g fusion protein, which was mixed 1:1 to Freund's Complete Adjuvant. After 14 days a second immunization was performed with 1:1 fusion protein with Freund's incomplete Adjuvant. This step was repeated after 14 days, and finally the blood from the rabbit was collected after two weeks after the last immunization. The blood was incubated $1 \mathrm{~h}$ at $37^{\circ} \mathrm{C}$ and overnight at $4^{\circ} \mathrm{C}$. The agglutinated components were pelleted by centrifugation at $13,000 \mathrm{x}$ g for $15 \mathrm{~min}$. The aliquoted serum was stored at $-80^{\circ} \mathrm{C}$.

Alternatively, fusion proteins with part of the coding sequence were produced in order to isolate better antibodies. 


\subsubsection{Production of a Strep-Tag Fusion Protein}

A fusion protein with Strep tag II was produced using the „Strep-tag Kit“ (IBA, Göttingen). The Strep-tag II expression vector carry a strong promoter/operator region for the tetA resistance gene (tet-on) which can be fully induced by adding anhydrotetracycline (AHT) at a concentration that is not antibiotically effective. The plasmid encodes the tet repressor gene (which guarantees the repression of the promoter in the absence of the inducer), and a tandem ribosome binding site (RBS) that ensures efficient initiation of translation. The sequence of interest is cloned in the MCS using the site for $B s a \mathrm{I}$ or any of the other restriction sites in the $\mathrm{N}$-terminal position relative to the Strep-tag II protein.

One strategy is to use a modified PCR product that contains the $B s a \mathrm{I}$ restriction site at both 5 ' and 3 'ends (2.8.1.). This PCR fragment was then restricted with BsaI, ligated into the $B s a \mathrm{I}$ restricted vector and the resulting ligation reaction was transformed into $\mathrm{DH} 5 \alpha$ competent cells (2.7.2.). A positive clone was selected and a single colony was precultured in $3 \mathrm{ml} \mathrm{LB}$ Medium with ampicillin overnight at $30^{\circ} \mathrm{C}$ under shaking (200 rpm). $2 \mathrm{ml}$ of this pre-culture were used to inoculate $100 \mathrm{ml}$ of LB Medium-ampicillin which was incubated at $37^{\circ} \mathrm{C}$ under shaking $(200 \mathrm{rpm})$ until an $\mathrm{OD}_{550}=5.5$ was reached. $10 \mu \mathrm{l}$ Anhydrotetracycline (AHT) solution were added to the culture for induction of the fusion protein and incubation continued for another $3 \mathrm{~h}$. After that, the cells were harvested by centrifugation at 4,500x g, $4^{\circ} \mathrm{C}$ for $12 \mathrm{~min}$. The supernatant was discarded, (carefully pipetting the remaining medium) and the pellet was resuspended in $1 \mathrm{ml}$ pre-cooled buffer $\mathrm{W}$ at $4^{\circ} \mathrm{C}$. For the analysis of the total protein content via SDS-PAGE (2.9.4), 10 $\mu \mathrm{l}$ were removed from this suspension. The suspension was sonicated under ice-cooling until lysis was complete. To remove insoluble components, the suspension was centrifuged at $14,000 \mathrm{xg}, 4^{\circ} \mathrm{C}$ for $15 \mathrm{~min}$. The clear supernatant was carefully transferred to a clean tube. This extract was ready for affinity purification of the recombinant protein. $10 \mu 1$ aliquot were separated in an SDS-PAA gel to check the protein size. After this, the protein extract was used to immunize two New Zealand rabbits and later on to isolate the 


\section{Material and Methods}

Hook1 antibody present in the antiserum of these two rabbits. The purified antibody obtained ( $\alpha$-Hook1), was used for immunohistological studies.

$\begin{array}{lrl}\text { Anhydrotetracycline sol: } & \begin{array}{r}2 \mathrm{mg} / \mathrm{ml} \\ \text { Store at }-20^{\circ} \mathrm{C} \text { (light sensitive) }\end{array} \\ \text { Buffer W: } & 100 \mathrm{mM} & \text { Tris } / \mathrm{HCl}, \mathrm{pH} 8.0 \\ & 1 \mathrm{mM} & \text { EDTA }\end{array}$

\subsubsection{Semi dry Blot}

The proteins were separated by SDS PAGE (2.9.4.) and transferred to a membrane. For this, 6 pieces GB004 Whatman filter paper were cut at the size of the gel. For the blot, the graphite plates from the transfer equipment were rubbed down with $\mathrm{dH}_{2} \mathrm{O}$. Two pieces filter paper were soaked in anode I buffer, 1 piece was soaked in anode II buffer and the paper pieces were piled on the transfer plate. The membrane was moistened with methanol and laid on the filter paper pile. The protein gel was taken out from the glass plates, the collecting gel was separated and eliminated; meanwhile the separating gel was carefully laid on the membrane. Finally, 3 pieces filter paper were soaked in the cathode buffer and laid on the gel. The air bubbles were eliminated with a roller. After the cathode plate was put in place, the transfer was done for $1 \mathrm{~h}$ at $3.5 \mathrm{~mA} / \mathrm{cm}^{2}$. The membrane was subjected to streptavidin detection (2.14.6.) or immune detection (2.14.8.).

$\begin{array}{lcl}\text { Anode I buffer: } & 0.3 \mathrm{M} & \begin{array}{l}\text { Tris/HCl, } \mathrm{pH} 10.4 \\ \text { Methanol }\end{array} \\ & 20 \%(\mathrm{v} / \mathrm{v}) & \\ \text { Anode II buffer: } & 25 \mathrm{mM} & \begin{array}{l}\text { Tris/HCl, } \mathrm{pH} 10.4 \\ \text { Methanol }\end{array} \\ & 20 \%(\mathrm{v} / \mathrm{v}) & \\ \text { Cathode buffer: } & 40 \mathrm{mM} & \begin{array}{l}\varepsilon \text {-Aminocaproic acid } \\ \text { Tris/HCl, } \mathrm{pH} 9.4 \\ \end{array} \\ 25 \mathrm{mM} & 20 \%(\mathrm{v} / \mathrm{v}) & \begin{array}{l}\text { Methanol } \\ \end{array}\end{array}$

\subsubsection{Streptavidin Detection of the Fusion Protein via Western Blot}

The fusion protein can easily be purified by the affinity of the Strep tag II to Strep Tactin which is an engineered form of streptavidin. The conjugate streptavidin-AP (alkaline 
phosphatase) was used to detect the fusion protein in a western blot membrane due to the great affinity that Strep tag II has to streptavidin.

After SDS PAGE (2.9.4.) and electrotransfer of the proteins to a PVDF membrane (2.14.5.), the filter was blocked with $\sim 20 \mathrm{ml}$ blocking solution II for $1 \mathrm{~h}$ at RT or overnight at $4^{\circ} \mathrm{C}$. Afterwards, the membrane was washed 3 times for 5 min each with PBT II. Then, the membrane was blocked for $10 \mathrm{~min}$ with avidin solution $(10 \mathrm{mg} / \mathrm{ml}$ in PBS II, 1:5,000) at RT with gentle shaking; avidin blocks specifically the endogenous biotin carboxyl carrier protein $(\mathrm{BCCP}, 22 \mathrm{kDa})$ of E. coli. Streptavidin alkaline phosphatase conjugate $(1: 4,000)$ was added and incubated for $60 \mathrm{~min}$ at RT with gentle shaking for the detection of the recombinant protein. Afterwards, the membrane was washed 3 times with PBT II and 2 times with PBS II (1 min per washing step). The chromogenic reaction was performed with $10 \mu \mathrm{l}$ NBT solution (2.12.4.) and $60 \mu \mathrm{l}$ BCIP solution in $20 \mathrm{ml}$ of buffer D until the pattern appears. This reaction was stopped by washing the membrane several times with $\mathrm{dH}_{2} \mathrm{O}$. The membrane was air dried and stored in the dark.

$\begin{array}{lrl}\text { 1x PBS II } & 4 \mathrm{mM} & \mathrm{KH}_{2} \mathrm{PO}_{4} \\ & 16 \mathrm{mM} & \mathrm{Na}_{2} \mathrm{HPO}_{4} \\ & 115 \mathrm{mM} & \mathrm{NaCl} \\ & 3 \% & \mathrm{BSA} \\ \text { Blocking solution II: } & 0.5 \% & \text { Tween } 20 \text { in } 1 \times \text { PBSII } \\ & & \\ \text { PBT II } & 0.1 \%(\mathrm{v} / \mathrm{v}) & \text { Tween } 20 \text { in 1x PBSII } \\ & & \\ \text { Buffer D } & 100 \mathrm{mM} & \mathrm{NaCl} \\ & 5 \mathrm{mM} & \mathrm{MgCl}_{2} \\ & 100 \mathrm{mM} & \text { Tris } / \mathrm{HCl}, \mathrm{pH} 8.8\end{array}$

\subsubsection{Purification of Monospecific Antibodies}

The antibodies against the protein of interest present in the polyclonal serum have to be purified so that good protein analysis can be performed. For this, a bacterial protein extract which contains a fusion protein with Strep tag II and the recombinant protein were separated by SDS PAGE (2.9.4.) and transferred to a membrane (2.14.5.). After the transfer, a stripe from the edge of the filter was cut out and coloured with streptavidin (2.14.5.) to localize the fusion protein. Then, the part of the filter containing the fusion 
protein was cut out, blocked for $1 \mathrm{~h}$ and incubated for $1 \mathrm{~h}$ with $200 \mu \mathrm{l}$ of the polyclonal antiserum. The membrane was washed 3 times for $10 \mathrm{~min}$ with washing buffer and 2 times for $5 \mathrm{~min}$ with PBS. The bound monospecific antibodies were eluted from the membrane with 1-5 ml elution buffer under vortexing for $15 \mathrm{~min}$. After a washing step with PBS for $5 \mathrm{~min}$, the membrane was blocked again for minimum $15 \mathrm{~min}$ and the elution procedure was repeated 3 times more. The eluted antibodies were transferred to a Centrisart tube (Sartorius AG, Göttingen) and concentrated by centrifugation at 2,500x g. The supernatant contained in the inner tube was removed and the outer tube was refilled with PBS and centrifuged again. These steps were repeated until the KSCN was completely removed from the antibody solution (3-4 times). The monospecific antibody solution was stored at $4^{\circ} \mathrm{C}$.

$\begin{array}{lll}\text { Elution buffer: } & 3 \mathrm{M} & \mathrm{KSCN} \\ 0.1 \%(\mathrm{w} / \mathrm{v}) & \mathrm{BSA} \text { in } 1 \mathrm{x} \mathrm{PBS}\end{array}$

\subsubsection{Western Blot Immune Detection}

The unspecific binding sites present in a membrane were saturated by using blocking buffer I for $30 \mathrm{~min}-1 \mathrm{~h}$. Then, the filter was incubated in a plastic bag with $1 \mathrm{ml} / 10 \mathrm{~cm}^{2}$ antiserum (diluted 1:500 in washing buffer) for $1 \mathrm{~h}$ at RT or overnight at $4^{\circ} \mathrm{C}$. Unbound antibodies were removed by using washing buffer 3x $20 \mathrm{~min}$. The second antibody coupled with alkaline phosphatase was diluted 1:5000 in washing buffer and added to the filter for $1 \mathrm{~h}$ under swinging shaking. Later, the unbound antibodies were removed with washing buffer 4 times for $10 \mathrm{~min}$ each. The filter was then washed with buffer 3 (2.9.3.) for $5 \mathrm{~min}$ and later incubated in a plastic bag with color solution (2.9.3.). The color reaction was allowed to develop in the dark. Then, the filter was washed shortly in $\mathrm{dH}_{2} \mathrm{O}$ and dried on filter paper.
10x Washing stock:
1.4 M $\quad \mathrm{NaCl}$
$100 \mathrm{mM} \quad$ Tris/HCl, $\mathrm{pH} 7.5$
$0.5 \%(\mathrm{v} / \mathrm{v}) \quad$ Tween 20
Blocking buffer I:
$5 \%(\mathrm{w} / \mathrm{v})$ Skimmed powder milk in Washing stock $1 \mathrm{x}$
Washing buffer:
$2 \%(\mathrm{w} / \mathrm{v})$ Skimmed powder milk in 


\section{1x Washing stock}

\subsubsection{Fluorescence in situ Hybridisation (FISH) for the Determination of Chromosomal Localisation}

Newborn WMP1 mice, which carry nine pairs of easily identifiable Robertsonian translocation chromosomes (Said et al., 1986) were injected with the leukemia virus, and a stable cell line was established. From this cell line metaphases were prepared. After hybridisation with the Hook cosmid clone, detection via fluoresceinated avidin (FITCavidin). Chromosomes were counterstained with 4,6-diamine-2-phenylindole dihydrochloride (DAPI). Images of emitted light were captured separately by use of the DAPI and FITC filter set and subsequently merged and aligned.

\subsubsection{Nick translation (preparation of the FISH probe)}

For the preparation of the probe used for the FISH assay, the following components were mixed:

\begin{tabular}{|c|c|}
\hline $1 \mu \mathrm{g}$ & DNA \\
\hline $5 \mu 1$ & dNTP (without dTTP) \\
\hline $1.5 \mu 1$ & Biotin 16dUTP \\
\hline $5 \mu 1$ & enzyme \\
\hline $\mathrm{x} \mu \mathrm{l}$ & $\mathrm{dH}_{2} \mathrm{O}$ \\
\hline $50 \mu \mathrm{l}$ & Total volume \\
\hline
\end{tabular}

The reaction was carried out at $16^{\circ} \mathrm{C}$ for $90 \mathrm{~min} .10 \mu 1$ reaction were denatured at $99^{\circ} \mathrm{C}$ for $5 \mathrm{~min}$, and then cooled on ice. The probe was then run on a 1.5-1.6\% agarose gel to determine if the reaction was successful. After adding $4 \mu 1$ salmon sperm DNA, $10 \mu 1$ mouse Cot1 DNA, and $100 \mu 199 \%$ Ethanol to $15 \mu 1$ DNA probe, the reaction was terminated by the addition of $10 \% 3 \mathrm{M} \mathrm{Na}$ Acetate, $\mathrm{pH} 4.8$, and 2.5 vol ice-cold $100 \%$ ethanol, followed by the centrifugation at $15,000 \mathrm{x}$ g, at $4{ }^{\circ} \mathrm{C}$. The pellet was washed with $70 \%$ ice-cold ethanol in order to remove excess salt and then resuspended in $5 \mu 1$ deionised formamide at $37^{\circ} \mathrm{C}$ for $30 \mathrm{~min}$. Then $5 \mu \mathrm{l}$ CISS-master mix was added to the probe and the reaction was denatured at $75-80^{\circ} \mathrm{C}$ for $5 \mathrm{~min}$. Preannealing of the DNA probe with Cot1-DNA was perfomed for $20-30 \mathrm{~min}$ at $37^{\circ} \mathrm{C}$. 
$\begin{array}{lll}\text { CISS-Master mix: } & \begin{array}{ll}20 \% & \text { Dextran sulfate } \\ 2 \mathrm{x} & \text { SSC }\end{array}\end{array}$

\subsubsection{Pre-handling of the Chromosome Preparations}

Preparations with suitable metaphase stage chromosomes were chosen. To each slide, $150 \mu 1$ RNase solution were added and covered with a cover slide. Incubation was carried out at $37^{\circ} \mathrm{C}$ for $60 \mathrm{~min}$ in a wet chamber. Then the slides were washed 3 times with $2 \mathrm{x}$ $\mathrm{SSC}$ for $5 \mathrm{~min}$ at RT during which the cover slides were released.

The slides were placed in a pepsin solution, pre-warmed to $37^{\circ} \mathrm{C}$ and incubated for $7 \mathrm{~min}$ $30 \mathrm{sec}$. Then, the slides were washed 2 times PBS for $5 \mathrm{~min}$ and 1 time with $\mathrm{PBS}-\mathrm{MgCl}_{2}$ for 5 min. A 15 min washing step with PBS- $\mathrm{MgCl}_{2} /$ formaldehyde followed. The slides were incubated in PBS for $5 \mathrm{~min}$ at RT. Finally, all the slides were placed for $2 \mathrm{~min}$ in each of the graded ice-cold ethanol solutions ( $70 \%, 85 \%$ and 99$)$, and then air dried. At this point, the slides are ready for pre-hybridisation.

\begin{tabular}{|c|c|c|}
\hline RNase solution: & $\begin{array}{r}10 \mu 1 \\
990 \mu 1\end{array}$ & $\begin{array}{l}\text { RNase } 10 \mathrm{mg} / \mathrm{ml} \\
2 \times \mathrm{SSC}, \mathrm{pH} 7.0\end{array}$ \\
\hline Pepsin solution: & $\begin{array}{l}30 \mu 1 \\
99 \mu 1\end{array}$ & $\begin{array}{l}\text { Pepsin } 10 \mathrm{mg} / \mathrm{ml} \\
0.1 \mathrm{~N} \mathrm{HCl}\end{array}$ \\
\hline PBS-MgCl ${ }_{2}$ : & $50 \mathrm{mM}$ & $\mathrm{MgCl}_{2}$ in PBS \\
\hline 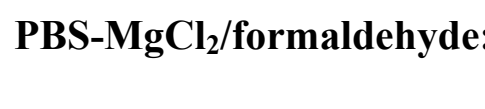 & $\begin{array}{r}: \quad 2 \mathrm{ml} \\
62 \mathrm{ml}\end{array}$ & $\begin{array}{l}\text { Formaldehyde } \\
\text { PBS- } \mathrm{MgCl}_{2}\end{array}$ \\
\hline
\end{tabular}

\subsubsection{Denaturation of the Chromosome Preparation and Pre- hybridisation}

The slides were incubated in a pre-heated formamide/SSC solution at $70^{\circ} \mathrm{C}$ for $70 \mathrm{sec}$, and then immersed in ice-cold 2x SSC. After this, the slides were quickly rinsed in icecold $70 \%$ ethanol. Finally, all the slides were placed for 2 min each in $70 \%, 85 \%$ and 99\% ice-cold ethanol. The slides were then air dried and ready for hybridisation.

$\begin{array}{lll}\text { Formamide/SSC solution: } & 70 \% & \text { Formamide } \\ 30 \% & 2 \mathrm{xSC}\end{array}$

\subsubsection{Denaturation of the DNA Probe and Hybridisation}


Initially, the nick translated probe was pre-incubated at $75^{\circ} \mathrm{C}$ for $10 \mathrm{~min}$ in the heating block and then incubated for $25 \mathrm{~min}$ at $37^{\circ} \mathrm{C}$. Later, the slides were incubated with $12 \mu \mathrm{l}$ of the probe in a wet chamber. In this step, the slide should be sealed with a cover slide and gum taking care of eliminating all air bubbles. The following washing steps were done at $45^{\circ} \mathrm{C}$ unless otherwise stated. After hybridisation, the gum was removed from the slides and they were washed 3 times in 50\% formamide in 2x SSC for $10 \mathrm{~min}$. Then, they were placed in 2x SSC for $5 \mathrm{~min}$. The slides were then placed in $80 \mathrm{ml}$ blocking solution for $30 \mathrm{~min}$ at $37^{\circ} \mathrm{C}$. Later, the slides were incubated for $30 \mathrm{~min}$ at $37^{\circ} \mathrm{C}$ with FITC-avidin diluted 200x in buffer 1. The slides were then rinsed 3x with SSCT and pre-heated to $45^{\circ} \mathrm{C}$. The slides were next incubated for $45 \mathrm{~min}$ at $37^{\circ} \mathrm{C}$ with FITC-anti-avidin diluted $100 \mathrm{x}$ in buffer 1 . Then, slides were rinsed 3 times in SSCT preheated at $45^{\circ} \mathrm{C}$. All the mentioned steps were carried out in the dark. Incubation with FITC avidin was carried out again under the same conditions followed by 3 washing steps with SSCT. Finally, the slides were treated with DAPI (4,6-Diamino-2-phenylindol)-Propidium iodide solution for $5 \mathrm{~min}$. The slides were briefly rinsed 3 times in $\mathrm{dH}_{2} \mathrm{O}$ and air dried. They were stored in the dark at RT before microscopic examination.

$\begin{array}{lrl}\text { Blocking solution: } & 5 \% & \text { BSA } \\ & 0.1 \% & \text { Tween } 20 \text { in } 4 \mathrm{x} \mathrm{SSC}, \mathrm{pH} 7.0 \\ \text { Buffer 1: } & 1 \% & \text { BSA } \\ & 0.1 \% & \text { Tween } 20 \text { in } 4 \mathrm{x} \mathrm{SSC}, \mathrm{pH} 7.0 \\ & & \\ \text { SSCT: } & 0.1 \% & \text { Tween } 20 \text { in } 4 \mathrm{x} \mathrm{SSC} \\ \text { DAPI/PropidiumI: } & 50 \mu 1 & \text { DAPI }(1 \mathrm{mg} / \mathrm{ml}) \\ & 30 \mu 1 & \text { Propidium iodide }(0.1 \mathrm{mg} / \mathrm{ml}) \\ & 0.1 \% & \text { Tween } 20 \\ & 70 \mathrm{ml} & 4 x \text { SSC }\end{array}$

\subsection{Transfection}

The transfection involves the introduction of foreign DNA into mammalian cells for its expression. There are different types of procedures to perform a transfection. In this case, the "Superfect Transfection Reagent" (QIAGEN, Hilden) was chosen, which assembles DNA into compact structures inside of its spherical form with branches radiating from a central core and terminating at charged amino groups, all which optimizes the entry of 
DNA into the cell. The Superfect-DNA complexes possess a net positive charge that allows them to bind to negatively charged receptors (i.e., sialylated glycoproteins) on the surface of eukaryotic cells. Inside the cell, after the Superfect-DNA complex has fused with the endosome, it inhibits lysosomal nucleases, which ensures stability of this complexes and the transport of intact DNA into the nucleus.

\subsubsection{Generation of a Green Fluorescent Fusion Protein (GFP)}

The green fluorescent protein (GFP) is a very useful tool to perform sub-cellular localisation of proteins and to observe their expression, due to the green fluorescent light that emits at $507 \mathrm{~nm}$ after being excited at $488 \mathrm{~nm}$. A fusion protein with the enhanced green fluorescent protein (EGFP) was produced by cloning in frame the entire coding region of the protein of interest in C-terminal position with respect to the EGFP sequence. The pEGFP-C1 vector (Clontech, Heidelberg) carries a strong promoter (pCMV) and the SV40 poly A, which direct proper processing of the 3 'end of the EGFP mRNA. The sequence of interest was cloned in the MCS using the restriction sites of EcoRI and KpnI. This ligation reaction (2.5.2.) was transformed in DH5 $\alpha$ competent cells (2.7.2.), then, a positive clone was selected and a single colony was cultured to obtain enough quantities of DNA (2.4.3.). After checking the sequence subcloned in the expression vector by restriction analysis and sequencing (2.8.3.), the DNA was used for transfection.

\subsubsection{Transfection Reaction}

One day before transfection, around 80,000-100,000 of 3T3 NIH swiss albino mouse fibroblast cells were plated in flaskettes (Lab-Tek/Nalge Nunc, IL, USA) with DMEM+ (2.2.2.1.), and incubated overnight at $37^{\circ} \mathrm{C}$ with $5 \% \mathrm{CO}_{2}$. At the next day, $2 \mu \mathrm{g}$ DNA were mixed with $10 \mu \mathrm{l}$ Superfect and $100 \mu \mathrm{l}$ DMEM- in a reaction tube and were incubated at RT for $10 \mathrm{~min}$. The cells were washed with PBS and immediately covered with the Superfect-DNA mix plus $600 \mu 1$ of DMEM+. This mixture was incubated for 3$3.5 \mathrm{~h}$ at $37^{\circ} \mathrm{C}$, after which, the mix was removed and replaced with $2 \mathrm{ml} \mathrm{DMEM}+$. Then, the cells were incubated 1-2 days at $37^{\circ} \mathrm{C}$. After checking the growth rate of the cells, the medium was removed and the cells were fixed in methanol for $10 \mathrm{~min}$ and air-dried. Now, the cells were ready for microscopic analysis. 


\section{Material and Methods}

\subsection{Acrosome Reaction}

This technique is based in the property observed of three glycoproteins (hZP1, hZP2, and hZP3) present in mouse and hamster egg's extracellular coat or zona pellucida to induce sperm to undergo the acrosome reaction in vitro.

In this technique, mouse sperm from vas deferens and epididymis was cut in small pieces and was capacitated for $1 \mathrm{~h}\left(1 \times 10^{6} / \mathrm{ml}\right)$ with $1 \mathrm{ml}$ of the IVF. Med (Medicult). The tissue together with medium was placed in a reaction tube and spermatozoa were allowed to swim for $10 \mathrm{~min}$, after which only the medium was transferred to a new eppendorf cup with cut pipette tips. For the negative control, $200 \mu \mathrm{l}$ were transferred to an extra eppendorf cup. The tubes were centrifuged $2 \mathrm{~min}$ at $3000 \mathrm{rpm}$ and after that the supernatant was retired until only $50 \mu 1$ were left. This volume was mixed with Ionophore A23187 (Calbiochem) (end concentration $10 \mu \mathrm{M}$ in DMSO) and incubated at $37^{\circ} \mathrm{C}$ for 1 hour. Meanwhile, the negative control was incubated for 1 hour at $37^{\circ} \mathrm{C}$ with $2.5 \mu \mathrm{l}$ phosphor acid $5 \mathrm{mM}, \mathrm{pH}$ 2.5. The sperm were then fixated in $\sim 500 \mu \mathrm{l} 2 \%$ formaldehyde/PBS for $30 \mathrm{~min}$. After that, the mixture was centrifuged for $2 \mathrm{~min}$ at 4000 $\mathrm{rpm}$, and the supernatant was discarded. Then, the sperm were washed with $500 \mu 10.15$ $\mathrm{M}$ ammonium acetate, $\mathrm{pH} 9.0$ and centrifuged again. Later, the supernatant was discarded until leaving 50-100 $\mu 1$ and $30 \mu 1$ aliquots were extended per slide (Superfrost, Menzel Gläser) and were allowed to dry. After that, the sperm were stained with Coomasie G-250 in $3.5 \% \mathrm{H}_{2} \mathrm{O}_{2}$ for $2.5 \mathrm{~min}$ and washed with distilled water. Afterwards, the slides were covered with $30 \%$ Glycerol/PBS.

\subsection{Computer Analysis}

For the analysis of the nucleotide sequences some computer programs were used. BLAST, Advanced BLAST, BLAST 2 sequences, PubMed (Altschul, 1990; 1997) and online mendelian inheritance in man, (OMIM) from the National Center for Biotechnology Information (NCBI) web page that belongs to the National Institute of Health (NIH): "http://www.ncbi.nlm.nih.gov/omim/". The gene expression database (Gene Expression Database, 2001) of the Mouse Genome Informatics Web Site from the 
Jackson laboratory, http://www.informatics.jax.org was also used for mouse alleles, phenotypes and murine genome information. For translation, multiple alignment and protein characteristics prediction, the program DNASIS was used. For the protein analysis, the internet analysis program linker ExPASy tools, (http://www.expasy.ch/tools) was employed. 


\section{RESULTS}

\subsection{Introduction}

The natural fertilization begins when the oocyte is reached and penetrated by the spermatozoa. For this event to happen, the motility of the spermatozoa and the enzymatic machinery necessary to penetrate the zona pellucida of the oocyte constitute extremely important features. Therefore, the study of the genes involved in spermatogenesis constitutes an essential reproductive matter.

In this work two previously unknown mouse genes involved in reproduction and expressed in male testis were characterized. One gene proved to have a high similarity $(92 \%$ at the protein level) to the human Hook1 cDNA isolated after the analysis of the homolog gene in Drosophila (Krämer H and Phistry M, 1999), for this reason our gene was denominated Hook1. The second gene was denominated as TSEP22 (for testis specific expressed protein and its molecular weight of $22 \mathrm{kDa}$ ).

\subsection{Isolation and Characterization of the cDNA of the Mouse Hook1. 3.2.1. Identification of the murine Hook1 cDNA}

In order to obtain a complete cDNA of the mouse $8 \mathrm{kDa}$ dynein light chain, a mouse testes cDNA phage library (Uni-ZAP XR, Stratagene; CD-1, 10-12 weeks old; mixed germ cells) was screened with an $8 \mathrm{kDa}$ light chain (dlc1) partial cDNA as a probe under low stringency conditions $\left(50^{\circ} \mathrm{C}\right)$. By this means around 400,000 clones were examined. Apart from finding the dlc1 complete cDNA clone, also 10 different cDNA clones with very weak similarity to other mouse sequences previously reported in the database (BLAST, NCBI) were obtained (Table. 3.1.). These plasmid clones were obtained by in vivo excision from the previously isolated phagemid clones. All the clones were sequenced and used to perform in situ hybridisation in testis sections. Two clones from these pool were chosen for

further analysis, with basis on their expression in late spermatids obtained with the in situ hybridisation. 
III. Results

\begin{tabular}{|c|c|c|}
\hline NUMBER & $\begin{array}{l}\text { SIZE } \\
(\mathbf{k b})\end{array}$ & EXPRESSION PATTERN (Northern blot) \\
\hline 1 & 1.0 & $\begin{array}{l}\text { Two signals. One strong testis specific signal of } \sim 1.7 \\
\mathrm{~kb} \text {. Another signal of } \sim 2 \mathrm{~kb} \text { weak in all tissues. }\end{array}$ \\
\hline 7 & 2.2 & $\sim 4.3 \mathrm{~kb}$ testis specific signal. \\
\hline 10 & 1.8 & $\begin{array}{l}\sim 1 \mathrm{~kb} \text { signal present in muscle, lung and stronger in } \\
\text { testis. }\end{array}$ \\
\hline 13 & 1.9 & Testis specific signal. \\
\hline 22 & 1.8 & $\begin{array}{l}\text { Two signals of } \sim 7.4 \text { and } \sim 3 \mathrm{~kb} \text { in all tissues, stronger } \\
\text { in muscle, kidney, spleen and testis. }\end{array}$ \\
\hline 25 & 1.6 & $\begin{array}{c}\sim 2.4 \mathrm{~kb} \text { testis specific signal. Mouse hook1 cDNA } \\
\text { clone. }\end{array}$ \\
\hline 36 & 0.8 & $\begin{array}{c}\text { Two testis specific signals of } \sim 1.2 \text { and } \sim 1.0 \mathrm{~kb} \text {. } \\
\text { TSEP22 cDNA clone. }\end{array}$ \\
\hline 37 & 1.2 & $\sim 1.8 \mathrm{~kb}$ signal present in kidney and stronger in testis. \\
\hline 38 & 1.7 & Two signals of $\sim 3.0$ and $\sim 2.0 \mathrm{~kb}$. \\
\hline 39 & 2.5 & $\begin{array}{c}\text { One testis specific signal of } \sim 2.3 \mathrm{~kb} \text { and two signals in } \\
\text { kidney of } \sim 4.3 \text { and } \sim 3.5 \mathrm{~kb} .\end{array}$ \\
\hline
\end{tabular}

Table 3.1. cDNA clones isolated by screening a mouse testes cDNA phage library.

This table presents the different cDNA clones isolated from a mouse testes cDNA phage library. They were given a number randomly and it is depicted their size and expression pattern obtained by northern blot.

\subsubsection{Mouse Hook1 cDNA}

The Hook1 clone comprised $1806 \mathrm{bp}$ and presented the cDNA polyA tail in the 3 'end together with the atypical polyadenylation signal AAGAAA. An open reading frame (ORF) was observed in the complete cDNA sequence, coding for 586 aa. What it could be considered as the start codon (ATG) was found after 42 aa from the beginning of the ORF and after comparing the sequence with the human Hook1 cDNA sequence in the database, the possibility that the protein sequence was incomplete was very high. Therefore, the isolation of additional cDNAs for this sequence was performed.

\subsubsection{Isolation of the Complete Hook1 cDNA}

The isolation of new cDNA clones for Hook1 was done by screening an RZPD (eessource Zentrum Primäre Datenbank des deutschen humanen Genomprojectes, Max Planck-Institut für molekulare Genetik, 14059 Berlin) mouse testes cDNA library consisting of 3 filters with the $1806 \mathrm{bp}$ Hook1 cDNA as a ${ }^{32} \mathrm{P}$-dCTP-labelled probe under high stringency conditions $\left(65^{\circ} \mathrm{C}\right)$. By this approach, 82,944 clones were screened and 12 clones contained 
in the vector pSport1 were obtained. The clones obtained by this screening were digested with the enzymes EcoRI and XbaI to cut out the insert, and the cDNAs 3, 5, 7, 10 and 12 were chosen for sequencing because they were larger than $1.8 \mathrm{~kb}$. From these, the clones 10 and 12 proved to have $100 \%$ similarity to the Hook 1 clone previously isolated and comprised a $2478 \mathrm{bp}$ sequence, plus a polyA tail. The sequence of these two clones had a similarity of $92 \%$ at the nucleotide level to the human Hook1 cDNA sequence from nucleotide 198, but the upstream 197 bp did not show similarity to any sequence previously reported. This 197 bp specific sequence was interpreted as being the 5'UTR of the mouse Hook1 gene.

\subsubsection{Nucleotide Sequence of the Complete cDNAs}

\subsubsection{Nucleotide Sequence of the Mouse Hook1 cDNA}

The complete nucleotide sequence of the Hook1 cDNA clone was defined by automatic sequencing using the primers localised in the vector T7 and T3, and the sequence specific primers A, B, C, D, E, F, G (Fig. 3.1.).

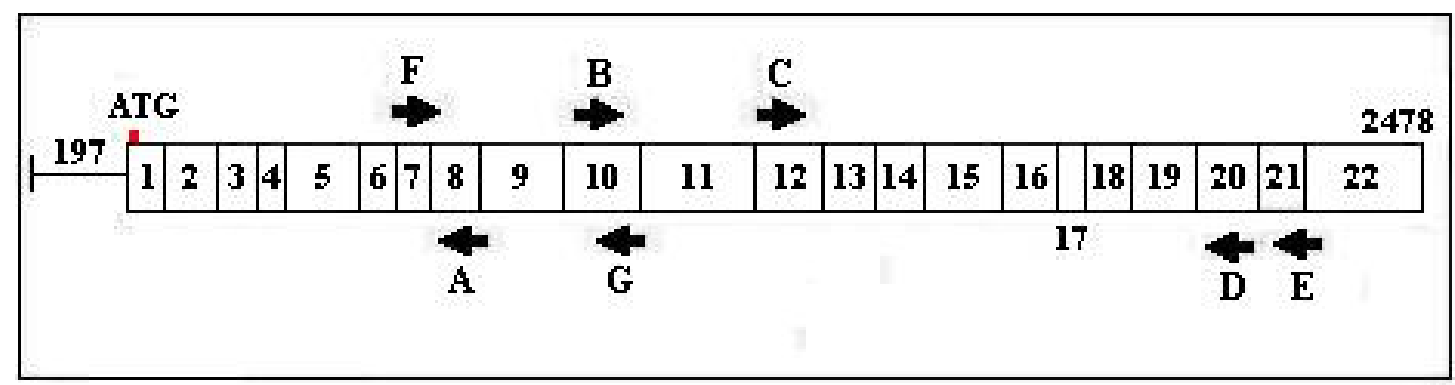

Fig. 3.1. Sequencing primers.

The figure shows the primers used to sequence the complete Hook1 cDNA.

The complete Hook1 cDNA clone comprised 2,478 bp including a 5' untranslated (5'UTR) region of $197 \mathrm{bp}$ and a 3'UTR of $94 \mathrm{bp}$. This clone contained the Kozak's consensus sequence $\mathrm{CCA} / \mathrm{GCC}(\mathrm{ATG}) \mathrm{G}$ for initiation of the translation in eucaryots around the start codon (Kozak, 1989) (Fig. 3.2.).

Hook1 cDNA and protein sequences for human and Drosophila were found in the Genbank database. It exists $85 \%$ and $92 \%$ of similarity between mouse and human at the nucleotide 


\section{Results}

and protein level, respectively. Thirty-seven percent of similarity is observed between the mouse and Drosophila proteins.

1 ' - CCACGCGTCCGGCGGGACAGACGCGGTGGGCGAGGGGGCGGTCGCGCCGCGACGTCTGCGCCGTGAGGCTTCGCGCGTGA

81

160

GTGGCGCGGGCGCCAGGCCTGGCCGCCGAGCTCCAGTGGCGGGCGCGGAGGTCGTTGACGCGGGCCCGGTCGGAGGCGCG

161

TCCGTCGCTGTGAGCGCGGCGTCGAGGTTCTCGGACCATGGAGGACCCGCAGCCGCTGCCACAGTCCGAGCTGCCGCTGT

241 $\begin{array}{llllllllllllllllllll}M & E & D & P & Q & P & L & P & Q & S & E & L & P & L\end{array}$

GTGACAGCCTCATCATCTGGCTGCAGACATTCAAGACTGCCTCACCTTGTCAAGATGTCAAACAGCTGACTAATGGAGT

$\begin{array}{lllllllllllllllllllllllllllll}C & D & S & L & I & I & W & L & Q & T & F & K & T & A & S & P & C & Q & D & V & K & Q & L & T & N & G & V\end{array}$

321

ACCATGGCACAAGTTCTTCATCAAATTGATGTAGCTTGGTTCAGCGAATCTTGGTTAAGCCGAATTAAAGATGATGTTGG

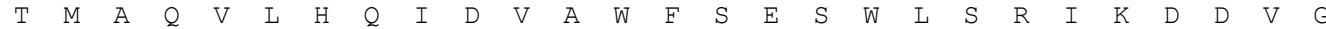
$401 \quad 480$

AGACAACTGGAGAATAAAGGCTAGTAACCTGAAGAAGGTCCTCCATGGAATTACAAGTTACTATCATGAGTTTTTGGGGC

$\begin{array}{llllllllllllllllllllllllllll}\mathrm{D} & \mathrm{N} & \mathrm{W} & \mathrm{R} & \mathrm{I} & \mathrm{K} & \mathrm{A} & \mathrm{S} & \mathrm{N} & \mathrm{L} & \mathrm{K} & \mathrm{K} & \mathrm{V} & \mathrm{L} & \mathrm{H} & \mathrm{G} & \mathrm{I} & \mathrm{T} & \mathrm{S} & \mathrm{Y} & \mathrm{Y} & \mathrm{H} & \mathrm{E} & \mathrm{F} & \mathrm{L} & \mathrm{G}\end{array}$

$481 \quad 560$

AGCAGATTTCTGAAGAACTTATCCCTGATTTAAATCAAATCACTGAGTGTGCAGATCCTGTGGAGCTTGGGAGGTTGCTT

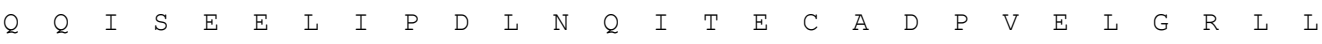

561

640

CAGCTAATTCTAGGATGTGCAGTCAACTGTGAAAAGAAGCAAGAACATATTAAAAATATAATGACCCTGGAAGAATCTGT

$\begin{array}{llllllllllllllllllllllllllll}Q & L & I & L & G & C & A & V & N & C & E & K & K & Q & E & H & I & K & N & I & M & T & L & E & E & S & V\end{array}$ 6412720

TCAACATGTGGTCATGACTGCAATTCAGGAGCTGATGAGTAAAGAAATAGTGATCTCTCCTGCAAGTGACACGGTGGGAG $\begin{array}{rlllllllllllllllllllllllll}Q & H & V & V & M & T & A & I & Q & E & L & M & S & K & E & I & V & I & S & P & A & S & D & T & V & G \\ 721 & & & & & & \end{array}$ AATTAGAACAGCAGCTTAAAAGGGCTTTAGAAGAGCTTCAGGAGGCCATAGCAGAAAAGGAAGAGCTGAAGCAGAGGTGC $\begin{array}{lllllllllllllllllllllllllll}E & L & E & Q & Q & L & K & R & A & L & E & E & L & Q & E & A & I & A & E & K & E & E & L & K & Q & R & C\end{array}$ 801 880

CAGGAACTGGATATGCAGGTGACTACACTTCAGGATGAGAAGAATTCACTGGTCTCTGAGAATGAGATGATGAATGAAAA

$\begin{array}{llllllllllllllllllllllllllll}Q & \mathrm{E} & \mathrm{L} & \mathrm{D} & \mathrm{M} & \mathrm{Q} & \mathrm{V} & \mathrm{T} & \mathrm{T} & \mathrm{L} & \mathrm{Q} & \mathrm{D} & \mathrm{E} & \mathrm{K} & \mathrm{N} & \mathrm{S} & \mathrm{L} & \mathrm{V} & \mathrm{S} & \mathrm{E} & \mathrm{N} & \mathrm{E} & \mathrm{M} & \mathrm{M} & \mathrm{N} & \mathrm{E} & \mathrm{K}\end{array}$ $881 \quad 960$ GCTTGACCAGTTGGATGGCTCTTTTGATGATCCAAATACAATGGTTGCAAAGAAATATTTTCACGTACAGCTACAACTAG $\begin{array}{rlllllllllllllllllllllllllll}L & D & Q & L & D & G & S & F & D & D & P & N & T & M & V & A & K & K & Y & F & H & V & Q & L & Q & L \\ 961 & & & & & & & & & & & & & & & & & & & & & & & 1040\end{array}$ AACAATTACAAGAAGAAAACTATAGGCTTGAAGCTGCAAAAGATGATTACCGTGTTCACTGTGAGGAACTTGAAAAGCAA $\begin{array}{lllllllllllllllllllllllllll}E & Q & L & Q & E & E & N & Y & R & L & E & A & A & K & D & D & Y & R & V & H & C & E & E & L & E & K & Q\end{array}$ $1041 \quad 1120$ CTGATTGAATTTCAGCACAGGAATGATGAGCTGACGAGCCTTGCTGAAGAGACCAGAGCCCTAAAAGATGAGATAGATGT $\begin{array}{llllllllllllllllllllllllllll}\mathrm{L} & \mathrm{I} & \mathrm{E} & \mathrm{F} & \mathrm{Q} & \mathrm{H} & \mathrm{R} & \mathrm{N} & \mathrm{D} & \mathrm{E} & \mathrm{L} & \mathrm{T} & \mathrm{S} & \mathrm{L} & \mathrm{A} & \mathrm{E} & \mathrm{E} & \mathrm{T} & \mathrm{R} & \mathrm{A} & \mathrm{L} & \mathrm{K} & \mathrm{D} & \mathrm{E} & \mathrm{I} & \mathrm{D} & \mathrm{V}\end{array}$ $1121 \quad 1200$ TCTTAGGGCTACGTCAGACAAAGCAAATAAACTGGAGTCAACAGTGGAGGTATATCGTCAGAAGCTACAAGATTTAAATG $\begin{array}{llllllllllllllllllllllllll}\mathrm{L} & \mathrm{R} & \mathrm{A} & \mathrm{T} & \mathrm{S} & \mathrm{D} & \mathrm{K} & \mathrm{A} & \mathrm{N} & \mathrm{K} & \mathrm{L} & \mathrm{E} & \mathrm{S} & \mathrm{T} & \mathrm{V} & \mathrm{E} & \mathrm{V} & \mathrm{Y} & \mathrm{R} & \mathrm{Q} & \mathrm{K} & \mathrm{L} & \mathrm{Q} & \mathrm{D} & \mathrm{L} & \mathrm{N}\end{array}$ $1201 \quad 1280$ ACCTCCGCAAACAGGTGAAATCTTTACAGGAGACAAATATGATGTATATGCATAACACTGTGAGCTTGGAAGAAGAGCTG $\begin{array}{llllllllllllllllllllllllllll}D & \mathrm{~L} & \mathrm{R} & \mathrm{K} & \mathrm{Q} & \mathrm{V} & \mathrm{K} & \mathrm{S} & \mathrm{L} & \mathrm{Q} & \mathrm{E} & \mathrm{T} & \mathrm{N} & \mathrm{M} & \mathrm{M} & \mathrm{Y} & \mathrm{M} & \mathrm{H} & \mathrm{N} & \mathrm{T} & \mathrm{V} & \mathrm{S} & \mathrm{L} & \mathrm{E} & \mathrm{E} & \mathrm{E} & \mathrm{L}\end{array}$ $1281 \quad 1360$

AAGAAGGCCAACGCAGCTCGGGCACAGTTAGAGACCTATAAGCGCCAGGTTCAGGACCTTCACACAAAGCTTTCCTCTGA $\begin{array}{lllllllllllllllllllllllllll}K & K & A & N & A & A & R & A & Q & L & E & T & Y & K & R & Q & V & Q & D & L & H & T & K & L & S & S & E\end{array}$ 1361 1440 ATCCAAAAGGGCAGATACACTAGCATTTGAAATGAAGAGGCTTGAAGAAAAACATGAAACTTTACTCAAGGAAAAAGAGC $\begin{array}{llllllllllllllllllllllllll}S & K & R & A & D & T & L & A & F & E & M & K & R & L & E & E & K & H & E & T & L & L & K & E & K & E\end{array}$ 1441 1520 GATTGATAGAACAGCGTGACACTCTGAAGGAGACGAATGAGGAGCTGCGGTGCTCAAAAGCACAGCAAGATCACTTAAAC $\begin{array}{llllllllllllllllllllllllllll}R & L & I & E & Q & R & D & T & L & K & E & T & N & E & E & L & R & C & S & K & A & Q & Q & D & H & L & N\end{array}$ $1521 \quad 1600$

CAAGCTGATGCATCTGCTACAAAAAGTTATGAAAATCTTGCTGCTGAGATCATGCCCGTGGAATACAGAGAGGTGTTCAT $\begin{array}{lllllllllllllllllllllllllllll}Q & A & D & A & S & A & \text { T } & \text { K } & \text { S } & \text { Y } & \text { E } & \text { N } & \text { L } & \text { A } & \text { A } & \text { E } & \text { I } & \text { M } & \text { P } & \text { V } & \text { E } & \text { Y } & \text { R } & \text { E } & \text { V } & \text { F } & \text { I }\end{array}$ 1601 1680 TCGACTCCAGCATGAAAACAAAATGCTTCGCCTACAGCAAGAAGGGACGGAGAATGAACGCATTGAGCAGCTGCAGGAGC $\begin{array}{clllllllllllllllllllllllll}R & \mathrm{~L} & \mathrm{Q} & \mathrm{H} & \mathrm{E} & \mathrm{N} & \mathrm{K} & \mathrm{M} & \mathrm{L} & \mathrm{R} & \mathrm{L} & \mathrm{Q} & \mathrm{Q} & \mathrm{E} & \mathrm{G} & \mathrm{T} & \mathrm{E} & \mathrm{N} & \mathrm{E} & \mathrm{R} & \mathrm{I} & \mathrm{E} & \mathrm{Q} & \mathrm{L} & \mathrm{Q} & \mathrm{E} \\ \end{array}$ AACTGGAGCAGAAGCACCGCAAGATGAATGAGCTGGAAACCGAGCAAAGGTTGAGCAAAGAGCGCATCGGAGAACTACAG 


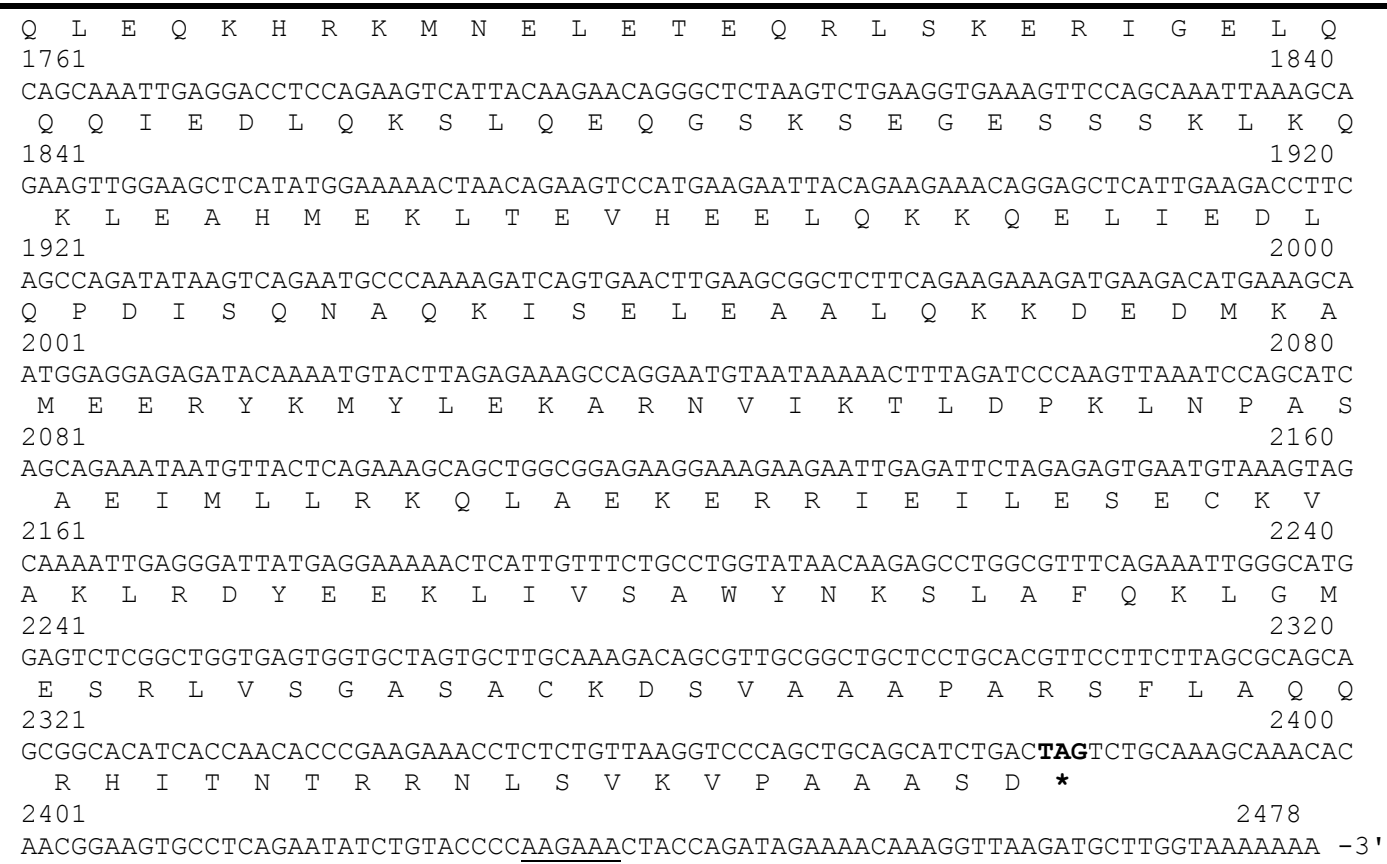

Fig. 3.2. Nucleotide sequence and translation of the Hook1 cDNA.

The amino acid sequence is shown below the nucleic acid sequence. The complete Hook1 cDNA sequence comprises $2478 \mathrm{bp}$ including a 5'UTR of $197 \mathrm{bp}$ and a 3'UTR of $94 \mathrm{bp}$. The start (ATG) and the stop (TAG) codons are highlighted, the Kozak consensus sequence and the atypical polyadenylation signal are underlined.

\subsubsection{Expression Analysis of the Mouse Hook1 Gene}

\subsubsection{Northern Blot Analysis of the Hook1 Gene in Mouse Tissues}

In order to determine in which tissues Hook1 is expressed, northern blot analyses were carried out. mRNA was isolated from a range of mouse tissues (such as testis, eye, muscle, brain, ovary, placenta, heart, liver, spleen and lung) and $20 \mu \mathrm{g}$ of mRNA of each tissue were separated on a $1.2 \%$ denaturing agarose gel, transferred onto a nitrocellulose filter and radioactively hybridized at $65^{\circ} \mathrm{C}$ with the $2.4 \mathrm{~kb}$ Hook 1 Sall/NotI fragment. The analysis of total mouse RNA revealed a strong testis specific signal of Hook1 of $\sim 2.4 \mathrm{~kb}$ (Fig. 3.3. A). This testis specific signal was observed after one week of exposition. Although, after a longer exposition time, additional signals of around $\sim 4 \mathrm{~kb}$ were detected in the other tissues, which seems to be a cross-hybridisation to the ribosomal 28s RNA, visible together with the ribosomal 18s RNA in the gel under UV light. The integrity of the RNA samples was confirmed by means of re-hybridising the northern blots with a human elongation factor cDNA (hEF) (Fig. 3.3, B). 


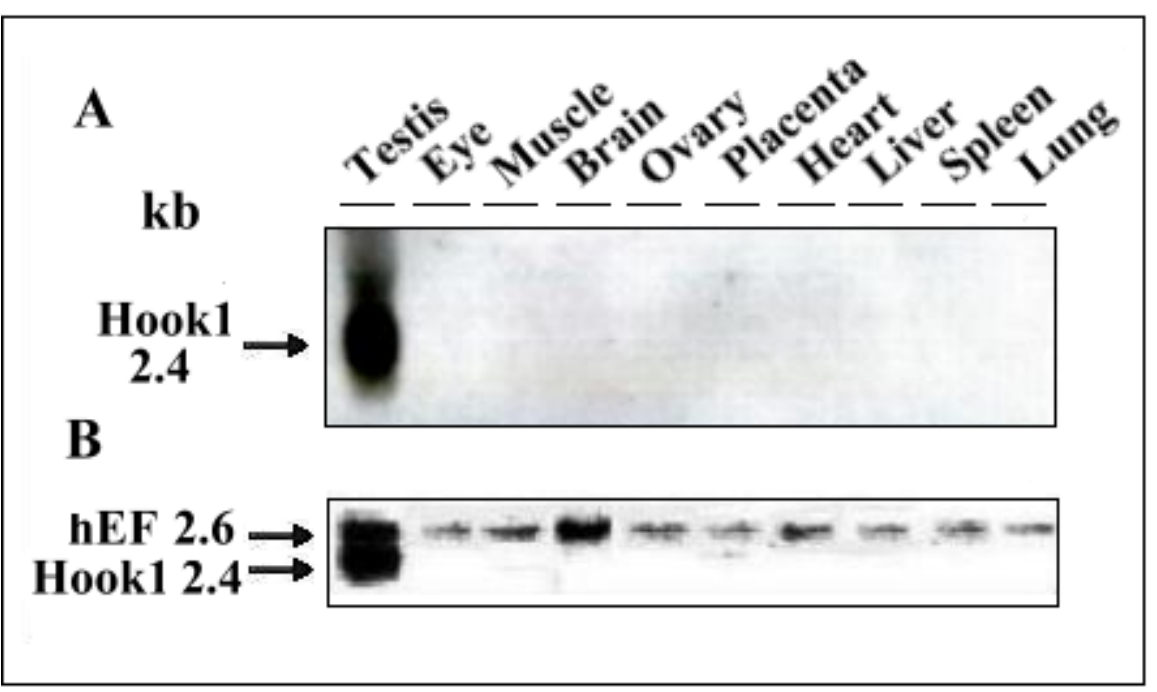

Fig. 3.3. Northern analysis of the expression of Hook1 in mouse adult tissues.

The total Hook1 cDNA was used as probe to hybridize $20 \mu \mathrm{g}$ of total RNA isolated from various mouse tissues under conditions of high stringency. The autoradiogram shows an overnight exposition. A: a 2.4 $\mathrm{kb}$ transcript was only observed in the testis sample. The length of the transcript was determined with the aid of an RNA marker (Gibco, BRL). B: Hybridisation with the Human elongation factor cDNA (hEF) to check the quality and quantity of RNA.

\subsubsection{Northern Blot Analysis of the Hook1 Gene in Testis of Mutant Mice}

Due to the strong signal observed in the testis in the northern blot from mouse tissues, northern blot analysis of mRNA from different mutant mice with defects at different levels of spermatogenesis was performed to determine in which spermatogenesis stage these transcripts are present. For this, the complete Hook1 cDNA was used as a radioactively labeled probe. No transcripts were observed in mutants presenting only somatic cells and no germ cells $\left(\mathrm{W} / \mathrm{W}^{\mathrm{v}}\right)$ or only premeiotical germ cells (LeyIL-/- and $\mathrm{Tfm} / \mathrm{Y}$, arrest in primary spermatocytes). Strong signals could be detected in strains containing postmeiotic germ cell stages, such as olt/olt and qk/qk (arrest in early spermatids and elongated spermatids, respectively) (Fig. 3.4.). 


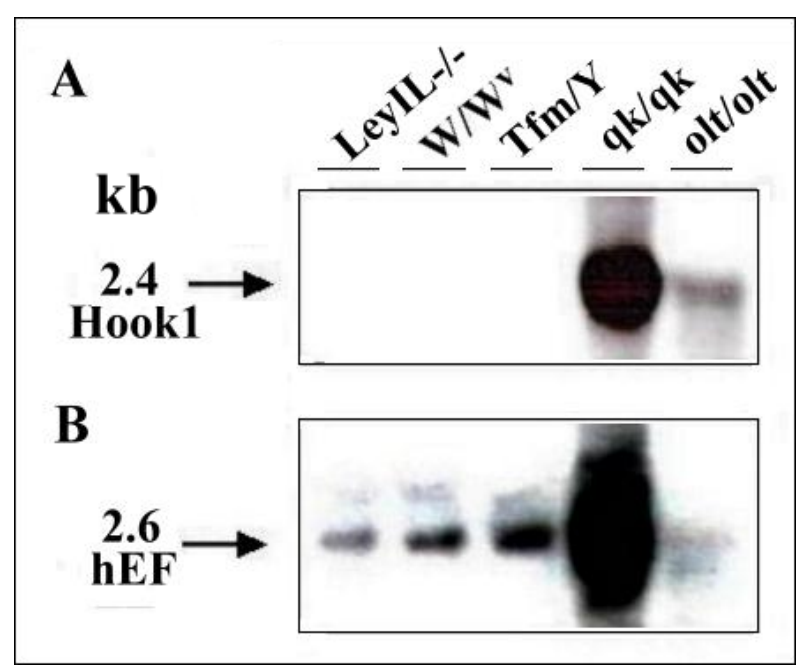

Fig. 3.4. Northern blot with testis RNA of adult mutant mice.

Analysis of different mutant mice testis RNA was performed by hybridising a blot with testis RNA of LeyIL-/-, W/W $\mathrm{W}^{\mathrm{v}}, \mathrm{Tfm} / \mathrm{Y}$, olt/olt and qk/qk mutant mice with the Hook1 cDNA. A: Positive signals were observed only in strains containing postmeiotic germ cell stages, such as olt/olt and qk/qk. No transcripts were detected in the rest of the mutant mice, which have only somatic cells and no germ cells $\left(\mathrm{W} / \mathrm{W}^{\mathrm{v}}\right)$ or only ameiotic germ cells in testis ( $\mathrm{Tfm} / \mathrm{Y}$, arrest in primary spermatocytes). B: Hybridisation with the Human elongation factor $\mathrm{CDNA}(\mathrm{hEF})$ to check the quality and quantity of RNA.

\subsubsection{Northern Blot Analyses of the Hook1 Gene in Testis during Development}

As long as a testis specific transcript was observed, the next step was determining the expression of the Hook1 gene in different germ cell stages. Therefore, mRNA from developing postnatal testes were extracted and used for northern blot analysis. Hybridisation signals could be first detected in the 25 days postnatal testis, which indicates that the expression of the gene starts in haploid germ cells (Fig. 3.5. A). Two other different transcripts could be detected in the developing testis samples of 6.2 and $4.3 \mathrm{~kb}$ after a longer exposition of the membrane (Fig. 3.5. B).

The $6.2 \mathrm{~kb}$ transcript was detected first at day 20 and the $4.3 \mathrm{~kb}$ transcript was observed at day 10. These transcripts are considerably weaker expressed than the previously described $2.4 \mathrm{~kb}$ Hook1 transcript and they are expressed in different testis development stages. Up to the moment, the origin of these larger transcripts is not clear. Hybridization with the human elongation factor cDNA proves the integrity and quantity of the RNA (3.5. C). 


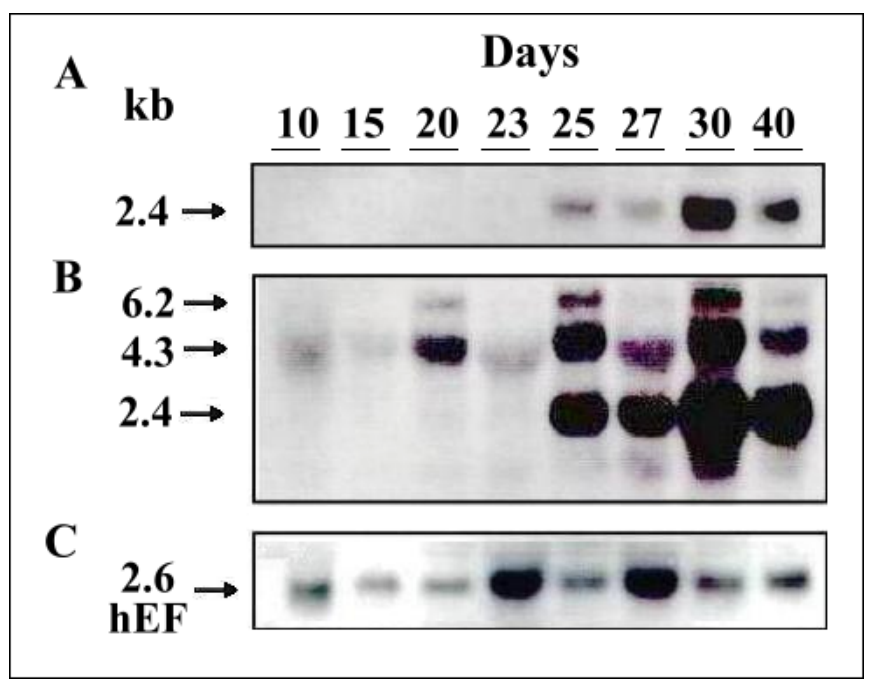

Fig. 3.5. . Northern analyses of the expression of murine Hook1 in different mouse developing testicular stages. The autoradiogram shows the hybridisation of a radioactive labeled probe containing the total Hook1 cDNA with $20 \mu \mathrm{g}$ of total RNA isolated from testes of mice 1 to 40 days old under conditions of high stringency. The autoradiograms $\mathrm{A}, \mathrm{B}$ and $\mathrm{C}$ were exposed for two, seven and two days respectively. A: expression was first observed from developing day 25 testis. B: after a longer exposition of the membrane, some other transcripts of 6.2 and $4.3 \mathrm{~kb}$ could be observed in the testis samples from day 20 and 10 respectively. C: Hybridisation with the Human elongation factor cDNA (hEF).

\subsubsection{Hook1 RTPCR Analysis with RNA from Adult Tissue and Embryonic Stages}

The RTPCR is a sensitive method for the analysis of the gene expression and has the advantage of using low quantities of RNA. This RTPCR was performed with the sequence specific primers $25 \mathrm{C}$ and $25 \mathrm{E}$ (Fig. 3.1.), using $\sim 1 \mu \mathrm{g}$ of RNA from testis, eye, kidney, brain, liver, heart, ovary, thymus, lung, placenta, spleen, colon and muscle. Simultaneously, the primers GAPDHfor and GAPDHrev for the glycerin aldehyde phosphate dehydrogenase gene (GAPDH), were included in the RTPCR reaction to verify the integrity and quantity of RNA.

The 715 bp Hook1 RTPCR fragment was present in almost all tissues, except spleen (Fig 3.6. A). When this gel was blotted and hybridized with the Hook1 cDNA as a radioactive probe, a positive signal was observed in all tissues except spleen (Fig. 3.6. B). The $458 \mathrm{bp}$ GAPDH RTPCR product could be observed in all the analysed tissues proving the integrity of the RNAs. 


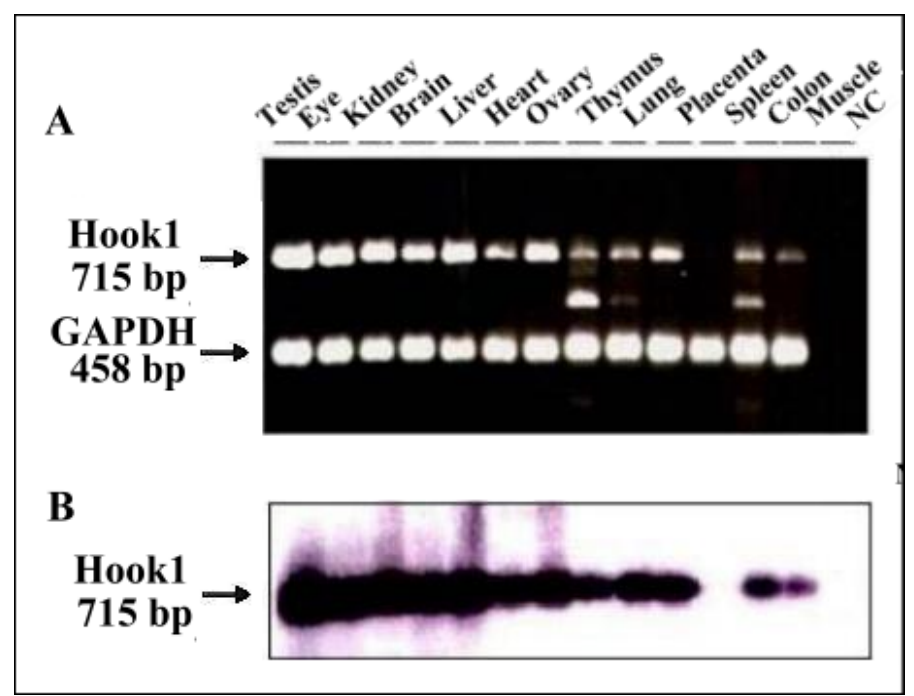

Fig. 3.6. RTPCR with adult mouse tissue RNA.

RTPCR was performed in mouse tissue RNA using the Hook1 specific primers 25C and 25D. A: A 715 bp RTPCR product was obtained in all but one of the analysed tissues, namely testis, eye, kidney, brain, liver, heart, ovary, thymus, lung, placenta, colon and muscle. No signal could be detected in spleen. The GAPDH primers were used as a control to prove the quality and quantity of the RNA. B: Hybridisation with the complete Hook1 cDNA as a radioactive labeled probe. In this case a positive signal was observed in all tissues, except in spleen. NC is for negative control.

To complete the expression analysis of the Hook1 gene, RTPCR was performed with RNA from different embryonic stages, in order to know if the Hook1 gene was expressed during prenatal development. RTPCR was done with blastocyst RNA as well as with RNA from 8.5-16.5 dpc embryos using the same sequence specific and control primers used with adult tissue RTPCR.

The expected 715 bp RTPCR Hook1 product could be amplified in all stages from 8.5 to 16.5 dpc (Fig. 3.7. A), but not in blastocyst. Also, the stages 8.5-10.5, 12.5,13.5 and 16.5 dpc presented faint bands. The control reaction with GADPH showed a 458 bp product in all analysed tissues, which was weak in blastocyst and the 8.5 embryonic stage and strong in the rest of the samples (Fig. 3.7. A). The agarose gel with these RTPCR products was blotted and hybridised with a Hook1 specific radioactive probe containing the complete cDNA.

After the radioactive hybridization a positive signal was observed in all embryonic stages from 8.5-16.5 dpc, but no signal was detected in blastocyst (Fig. 3.7. B). 


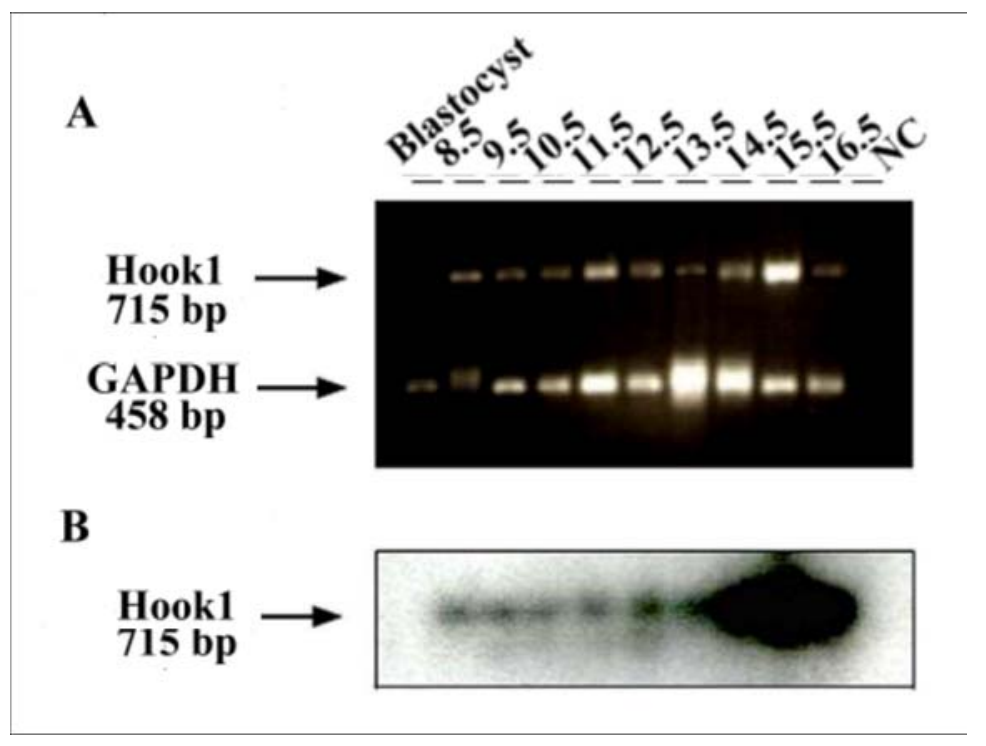

Fig. 3.7. RTPCR with mouse RNA from different embryonic stages.

RTPCR was performed in mouse RNA of blastocyst and embryonic stages from 8.5- 16.5 dpc using the Hook1 specific primers 25C and 25D. A: A 715 bp RTPCR product was obtained in all of the embryonic stages, except in blastocyst. The GAPDH primers were used as a control to prove the quality and quantity of RNA. B: Hybridisation with the complete Hook1 cDNA as a radioactive labeled probe, signals can be observed in all embryonic stages except in blastocyst. NC is for negative control.

\subsubsection{Hook1 in situ Hybridisation with Testis Sections}

To identify which germ cell type was involved in the testis specific expression of the Hook1 gene, in situ hybridisation in adult wild type mouse testis paraffin sections ( $7 \mu \mathrm{m}$ cut width) was performed. As a probe, the linearized plasmid comprising the Hook1 cDNA sequence labeled with DIG-rUTP via in vitro transcription was used. The "sense" and "antisense" probes were tested by dot blot with dilutions 1.100, 1:1000 and 1:10,000 and detected with anti-DIG coupled to alkaline phosphatase, after that, they were employed for the in situ hybridisation in testis sections. The antisense probe yielded signals that could be detected at the level of round spermatids, finding that together with the results of the postnatal developing testes northern blot, confirms the expression of the Hook1 gene to be localized postmeiotically to round and elongated spermatids (Fig. 3.8. A-C)). In the sense control, no signals could be detected (Fig. 3.8. D). 


\section{Results}

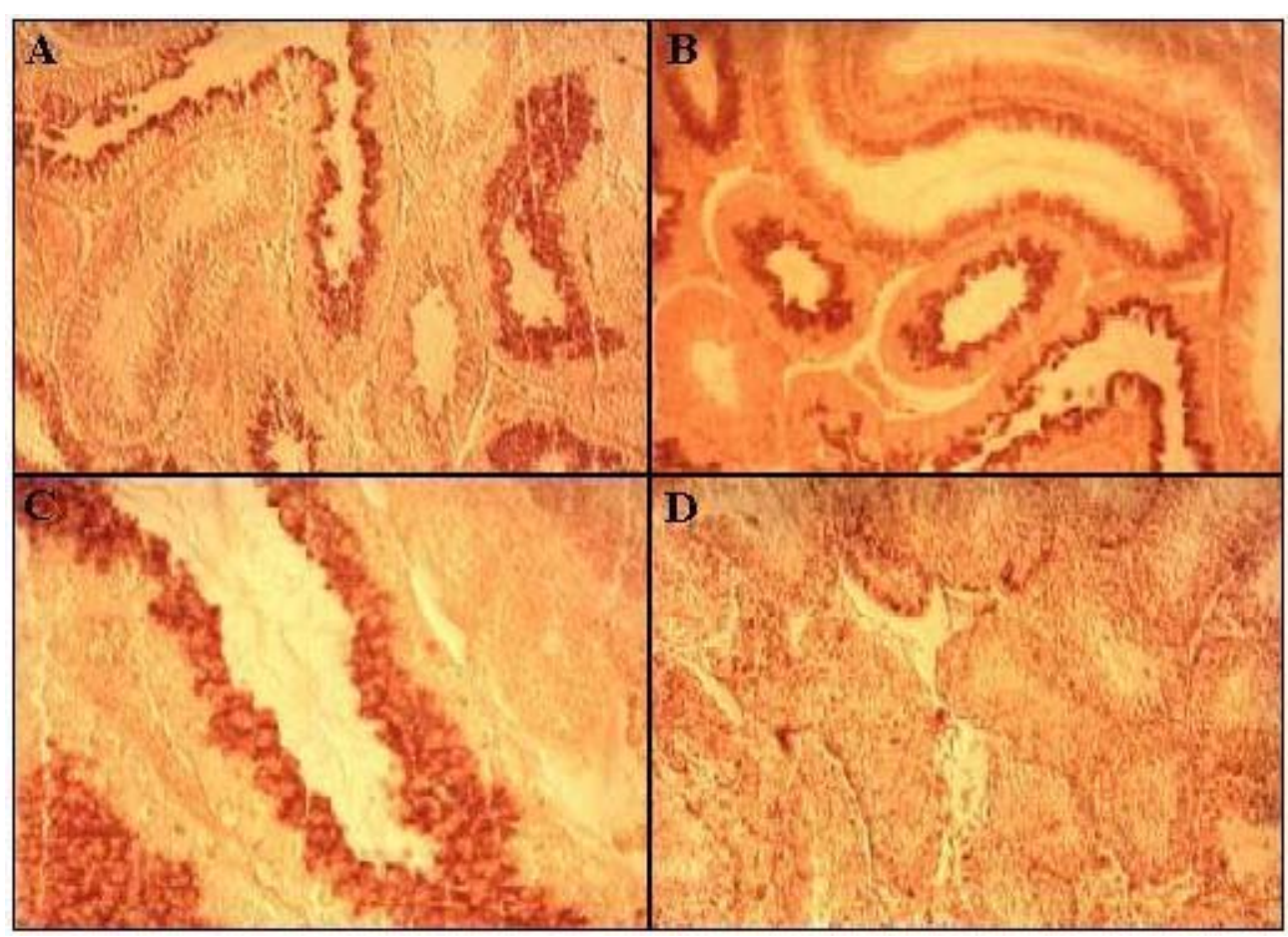

Fig. 3.8. Hook1 in situ hybridisation.

The expression of Hook1 was examined in adult mouse testis by in situ hybridisation. A DIG labeled Hook1 specific probe reveals the expression to be confined to late haploid germ cells, namely round and elongated spermatids (A-C). The sense probe yielded no signals (D).

\subsection{Genomic Analysis}

\subsubsection{Isolation of Cosmid Clones with Mouse Genomic DNA}

The isolation of cosmid clones with mouse genomic DNA was performed in order to characterize the genomic structure of the genes and to generate genomic probes for the chromosomal localisation.

An RZPD mouse genomic DNA cosmid library (strain SV 129) consisting of 11 filters was hybridized with the complete Hook1 cDNA radioactively labeled probe under high stringency conditions $\left(60^{\circ} \mathrm{C}\right) .304,128$ clones were screened with this library. Two different Hook 1 cosmid clones were chosen: clones 25 and 4, both $\sim 40 \mathrm{~kb}$ long.

\subsubsection{Hook1 Genomic Organisation}

The cosmid clone 25 containing the Hook1 gene was restricted with the enzymes BamHI, EcoRI, PstI and HindIII and their combination, blotted and radioactively hybridized (Fig. 3.9. A). Four bands (3.4 kb BamHI-EcoRI restricted, and 3.0, 1.0 and $0.5 \mathrm{~kb}$ PstI-HindIII 
restricted) with a positive signal were cloned into the pBluescript vector (Stratagene). These subclones were sequenced and the exon-intron boundaries present in these clones were elucidated (Fig. 3.9. B)

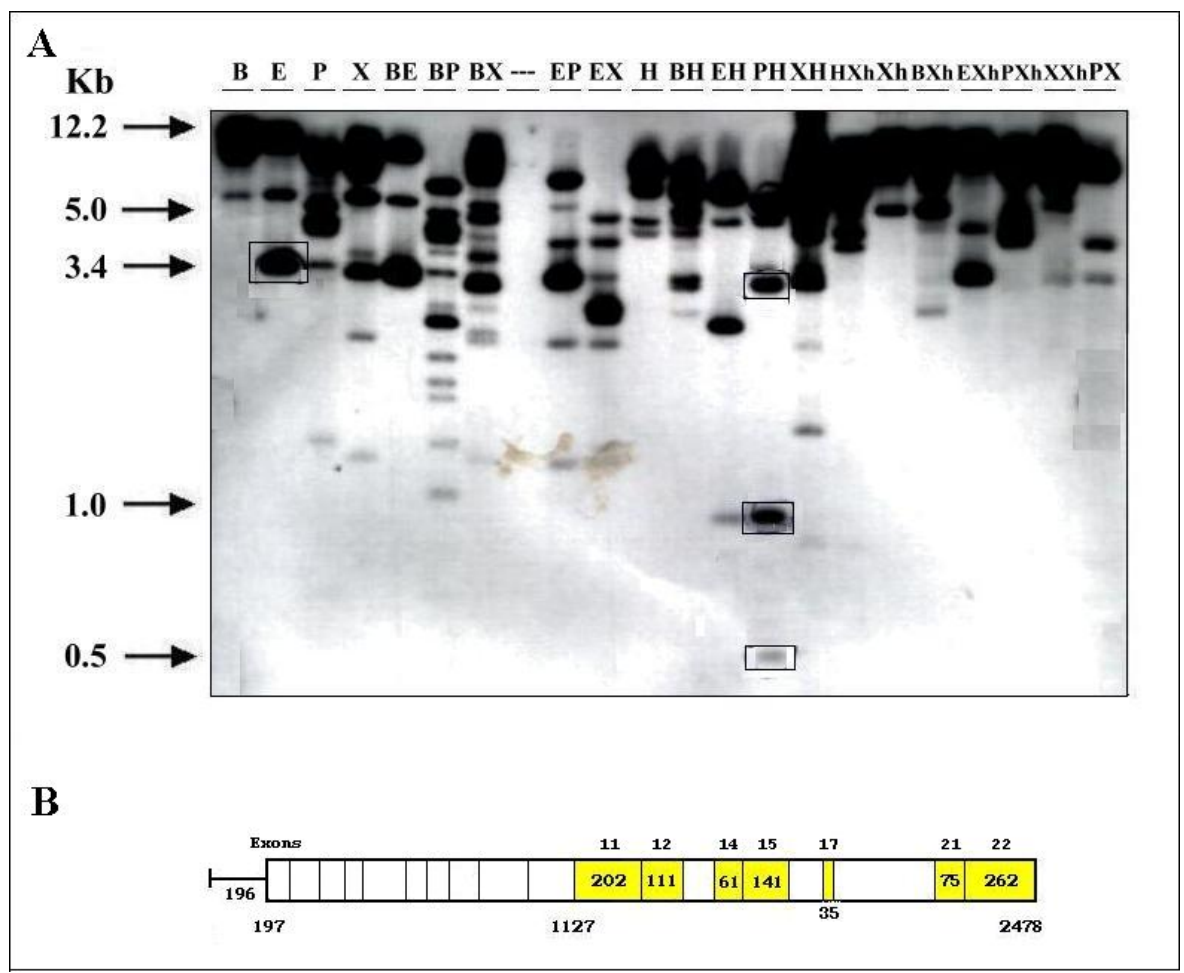

Fig. 3.9. Enzymatic digestion of the cosmid clone 25 and schematic representation of the sequenced exons. A: The figure shows the film of the enzymatic digestion of the mouse Hook1 genomic clone 25 with the enzymes BamHI (B), EcoRI (E), PstI (P), XbaI (X), XhoI (Xh) and their combination, after hybridization with the Hook1 cDNA. Four bands (3.4 kb BamHI-EcoRI restricted, and 3.0, 1.0 and $0.5 \mathrm{~kb}$ PstI-HindIII restricted, showed in boxes) with a positive signal were cloned into the pBluescript vector. These subclones were sequenced and the exon-intron boundaries present in these clones were elucidated (B). ).

Later on, three human genomic clones were found in the BLAST database of the National Center for Biotechnology Information (NCBI) (http://www.ncbi.nlm.nih.gov/BLAST/): with the accession numbers AC068202, AL138845 and AL352744 (which comprise the exons 1-8, 4-22 and 2-22 respectively), localised in chromosome 1p31.3. When the sequence of these clones was compared with the mouse Hook1 exons already found, a total exon-intron correspondence could be detected. Also, some mouse genomic clones were found in the Ensembl database (http://www.ensembl.org.), and together with the sequencing information, all exon-intron boundaries could be defined. From here, it can be stated that the mouse Hook1 gene displays the same genomic organization as the human 
Hook1 gene, which has 22 exons. In the case of the mouse Hook1 gene, an additional sequence of $197 \mathrm{bp}$ upstream to the first exon, namely the 5'UTR, is present (Fig. 3.10.). This 197 bp sequence do not show similarity to any sequence reported in the database.

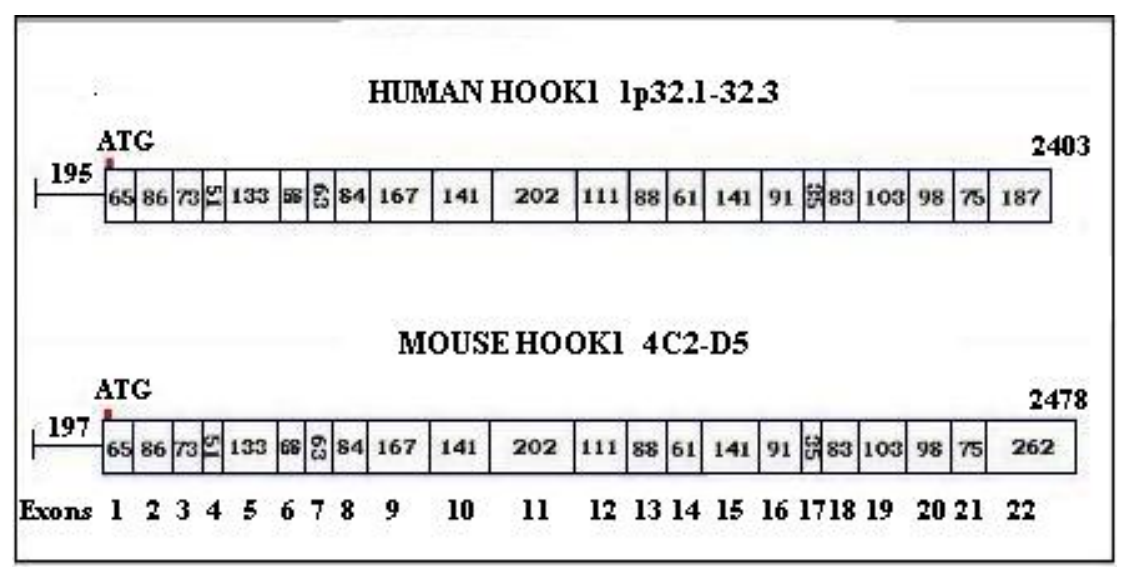

Fig. 3.10. Map with the genomic organization of the Hook1 gene in human and mouse.

The mouse Hook1 comprises 2478 bp and is localised to the mouse chromosome 4C5-D2, which is synthenic to the human chromosome 1p32.1-32.3, where the human Hook1 gene lies. The human Hook1 cDNA comprises $2403 \mathrm{bp}$ and is organized in 22 exons. The .mouse Hook1 cDNA is also organized as the human gene in 22 exons. Besides, the mouse cDNA has a 5'UTR of $197 \mathrm{bp}$.

\subsubsection{Southern Blot Analysis and Copy Gene Determination}

An important aspect of the genomic organisation of a gene concerns to the gene copy number in the genome. To prove this, $20 \mu \mathrm{g}$ of mouse genomic DNA were restricted with BamHI, EcoRI, PvuII and XbaI, separated in a horizontal gel and transferred to a membrane by normal Southern blot. This same procedure was performed with the cosmid clone DNA containing the Hook1 gene isolated from an RZPD mouse genomic DNA library. The filters were hybridized with the $2.4 \mathrm{~kb}$ complete Hook 1 cDNA as a radioactive probe at $65^{\circ} \mathrm{C}$. When the band pattern obtained in the mouse genomic DNA Southern blot (Fig. 3.11. A) was compared to that of the mouse cosmid clone (Fig. 3.11. B.), the most of the bands could be identified for the restrictions with BamHI and EcoRI. Only two bands of around 12 and $5 \mathrm{~kb}$ from the BamHI and EcoRI digestions, respectively, present in the mouse genomic DNA are not found in the cosmid clone digestions. As long as these missing bands are relatively small to contain a copy of the gene by themselves, it can be concluded that Hook1 is a single copy gene in the murine genome. 


\section{Results}

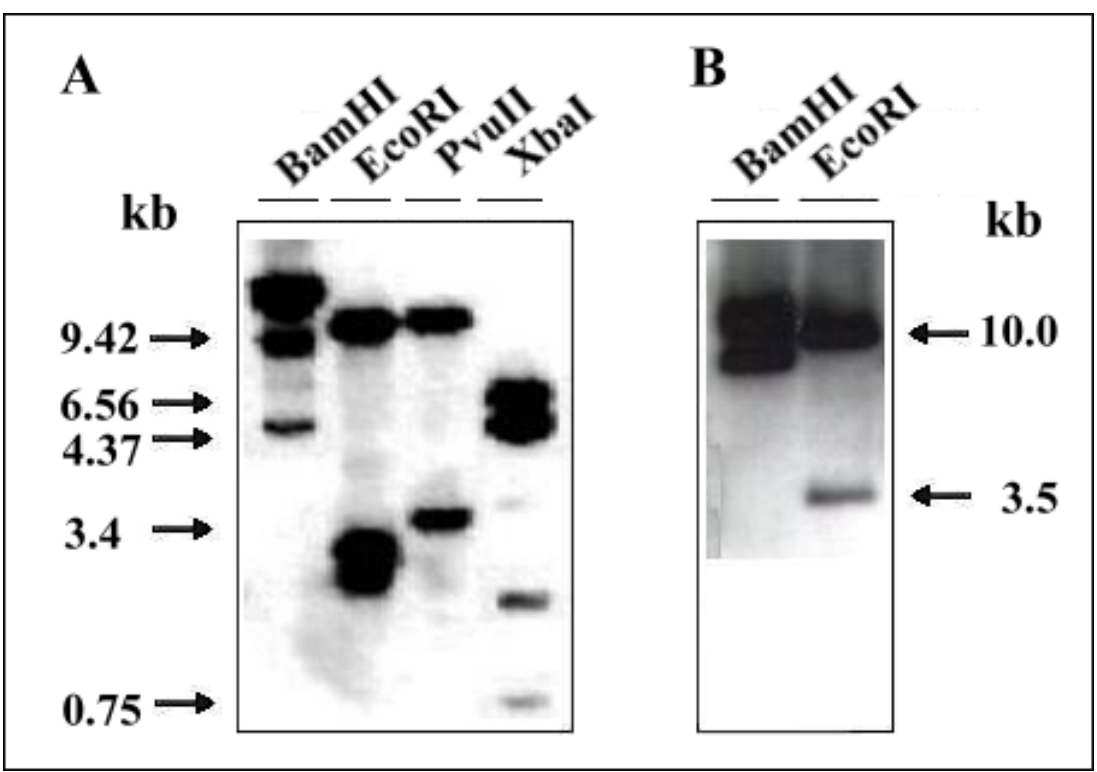

Fig. 3.11. Southern blot analysis of Hook1.

$20 \mu \mathrm{g}$ of mouse genomic DNA were first restricted with BamHI (B), EcoRI (E), PvuII (P) and XbaI (X), separated on a $0.8 \%$ agarose gel and blotted. The blot was then hybridised with the Hook1 complete cDNA as a probe. The comparison between the patterns obtained with the mouse genomic DNA (A) and the cosmid clone (B) yielded an almost total correspondence with BamHI and EcoRI enzymes. So it can be concluded that Hook1 is present once in the genome.

\subsubsection{Hook1 Chromosomal Localisation}

The chromosomal localisation of the mouse Hook1 gene was performed by Fluorescence In Situ Hybridisation (FISH) with help from Dr. Christa Dixkens (Institute of Human Genetics, University of Goettingen). For this purpose, the cosmid 25 was used as a probe. The mouse Hook1 gene was detected in the chromosome 4, region C5-D2 (Fig. 3.12.). This region is synthenic to the human chromosome $1 \mathrm{p} 32.1$ where the genomic clones containing the Hook1 gene are localised. These human genomic clones have the accession numbers AC068202, AL138845 and AL352744 (which comprise the exons 1-8, 4-22 and 2-22 of human Hook1 cDNA, respectively).

Looking in the database for information about this region of the mouse chromosome 4 , the mutant mouse azh/azh (for abnormal spermatozoon head shape) was found to be localised in the mouse chromosome 4C7 (Meistrich ML et al,.1992), This mouse displays an abnormal phenotype in the spermatozoa head, as clearly described in its name. As long as the mouse Hook1 gene was localised in this same chromosomal region and showed a strong expression in testis, the azh/azh mutant mouse was considered an ideal candidate for further analysis of the Hook1 gene (3.5.). 


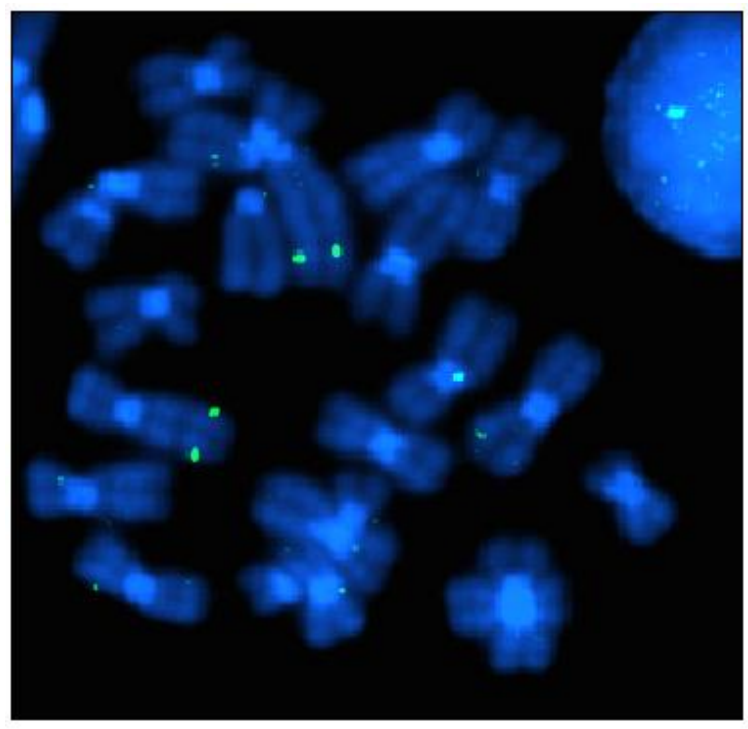

Fig. 3.12. Chromosomal localisation of the Hook1 gene.

The picture shows the FISH hybridisation to localise the Hook1 mouse gene using the cosmid 25 as a probe. Hook1 gene was located to mouse chromosome 4 region C5-D2 . Several mouse mutants are described in this region, being the azh/azh (abnormal spermatozoon head shape) mutant mice the only displaying a phenotype related with defects in spermatogenesis.

\subsection{Hook1 Protein Analysis}

\subsubsection{Sequence Analysis of the Hook1 Protein}

The putative Hook1 protein consists of 728 amino acid (aa) showing a molecular weight of $84,647 \mathrm{Da}$ and a predicted $\mathrm{pI}$ of 4.95. The rates of the amino acids glutamine (E, 13.6\%), leucine (L, 12.5\%) and lysine (K, 9.1\%), proved to be high if compared with the average expected content of $4 \%$ of each aa in any amino acid sequence. It has a coiled coil motif, which mediates homodimerization, feature that is present also in Drosophila and human Hook1.

Using different computer protein analysis programs, such as ScanProsite, ProfileScan, Pfam, ProtParam and Interpro, three motifs were found in the mouse Hook1 protein such as: filament (aa 171-196), spectrin repeat (aa 486-575) and two leucine zippers, the first in exons 8 and 9 and the second in exons 12 and 13 (Fig. 3.13). The first leucine zipper consisted of 4 leucine residues (aa 197, 204, 211, 218) and the second had 6 leucine residues (aa 395, 402, 409, 416, 423 and 430) (Fig. 3.20.). The filament and spectrin repeat domains suggest that Hook1 is a protein that probably interacts with the microtubules of the cytoskeleton. The leucine zipper domain is known to facilitate dimerization and is involved 
in regulation of the proteins. These filament, spectrin repeat and leucine zipper motifs are conserved in human and Drosophila Hook1, by the exception of the second leucine residue from the first leucine zipper, which is absent in Drosophila.

Also, two putative N-glycosylation sites were found in AA 671-4 and 717-20, as well as several putative phosphorylation and myristylation sites all along the amino acid sequence. No nuclear localisation signal could be found in the Hook1 sequence.

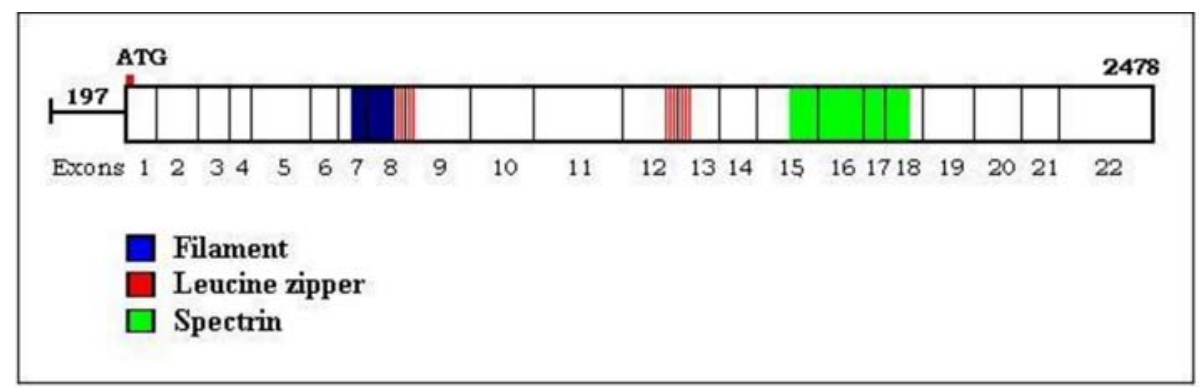

Fig. 3.13. Protein domains present in the Hook1 protein.

The Hook1 protein contains 4 putative domains: one filament domain, two leucine zippers and one spectrin repeat motif. The filament and spectrin repeats suggests that the Hook1 protein can probably interact with the microtubules of the cytoskeleton. The leucine zipper is known to facilitate dimerization and is involved in the regulation of the proteins.

\subsubsection{Production of a Hook1-Strep-tag Fusion Protein}

In order to continue the expression analysis of Hook1, a fusion protein with Strep-tag was generated to isolate a purified antibody against Hook1. To achieve this, a $546 \mathrm{bp}$ fragment comprising from the 1638-2184 bp of the hook cDNA was produced by PCR with the primers HPF and HPR. These primers contained an extra 5'sequence with the BsaI restriction site, which was incorporated at both 5'and 3'ends of the PCR product. This PCR product was restricted with BsaI and ligated to the vector pASK-IBA II (IBA, Goettingen). The resulting clones were cultured, purified and tested for the presence of the fusion protein by Western blot. After this, the clone with the best protein expression was purified to immunize two New Zealand rabbits and later on to isolate the Hook1 antibody present in the antiserum of these two rabbits. The New Zealand rabbits were immunized with $\sim 1 \mu \mathrm{g}$ of fusion protein, which was mixed 1:1 to Freund's Complete Adjuvant. After 14 days a second immunization was performed with a 1:1 mix of the fusion protein with Freund's incomplete Adjuvant. This step was repeated after 14 days, and finally the blood from the 
rabbit was collected after two weeks after the last immunization. The purified antibody obtained ( $\alpha$-Hook1), was used for immunohistological studies.

\subsubsection{Western Blot Analysis}

Western blot analysis was performed to know the Hook1 protein distribution. First, rabbit antibodies against Hook1 ( $\alpha$-Hook1) were proved. For this, a PAA gel was run with the Hook1-Streptag fusion protein and testis protein extract. In the membrane, after DIG staining, is possible to observe that the Hook1 protein is indeed recognized by the $\alpha$-Hook1 antibodies because a band of $84 \mathrm{kDa}$ can be detected in the testis protein extract, which is the molecular weight of the putative Hook1 protein and some other degradation products present in the fusion protein extract.

Later, a Western blot was performed with some mouse tissue protein extracts such as: testis, eye, brain and sperm using the $\alpha$-Hook1 antibodies (Fig. 3.14). It is possible to see that the band corresponding to the Hook1 protein could be detected in testis, eye and brain, but it was absent in sperm. The band present in testis was particularly stronger than that of eye and brain. This comparison can be made due to the use of mouse $\alpha$-tubulin, which was included as a control of the quantity and quality of the protein samples. This tubulin band is $55 \mathrm{~kb}$ and appears to have a similar intensity in all samples.

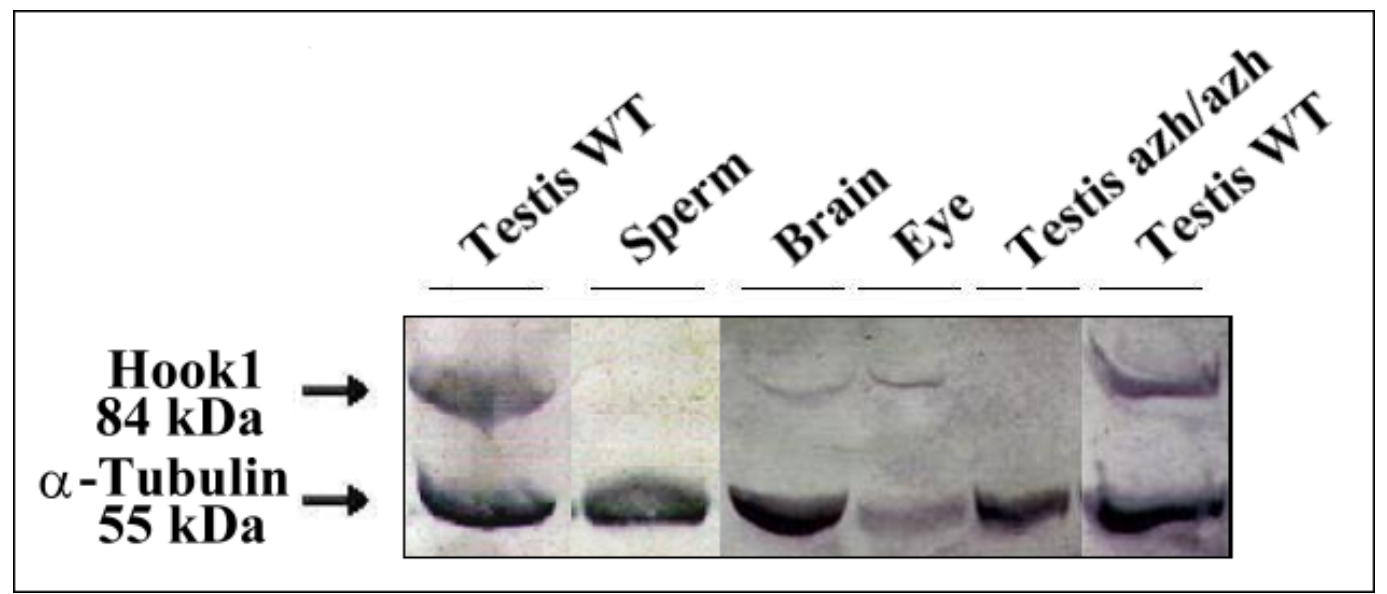

Fig. 3.14. Western blot analysis with protein extracts from different tissues. $\alpha$-Hook1 monospecific antibodies were assayed with proteins extracts of wild type testis, sperm, brain, eye, testis of azh/azh. A band of $\sim 84 \mathrm{kDa}$ can be observed in wild type testis, which is the molecular weight (MW) of the putative Hook1 protein. Hook1 protein is recognized by $\alpha$-Hook1 antibodies in brain and eye, but at lesser extent than in wild type testis. Also, sperm and azh/azh testis were tested, but both did not present any band. Therefore, Hook1 protein is not present in sperm and mutant testis protein extracts. 


\subsubsection{Immunohistological Analysis of Hook1 with Testis Sections}

The Hook1 transcript was previously detected in testis sections at the level of round and elongated spermatids (in situ hybridisation, 3.2.4.5.). Therefore, it was interesting to analyse the point when the Hook1 protein appears in testis. For this, an immunohistochemical analysis of Hook1 in paraffin testis sections from adult mouse (4-5 $\mu \mathrm{m}$ width) was performed. Mouse testis sections were incubated with purified monospecific rabbit $\alpha$-Hook1 antibodies. The control reaction was incubated with anti-goat negative serum instead. All the spermatozoa preparations were incubated with anti-rabbit $\alpha$-DIG coupled to alkaline phosphatase as second antibody (which recognized $\alpha$-Hook1

The positive signal of $\alpha$-Hook 1 can be observed as a dark purple staining at the level of round and elongated spermatids (Fig. 3.15., A-C). The testis slides incubated with the negative control showed no signals (Fig. 3.15., D).
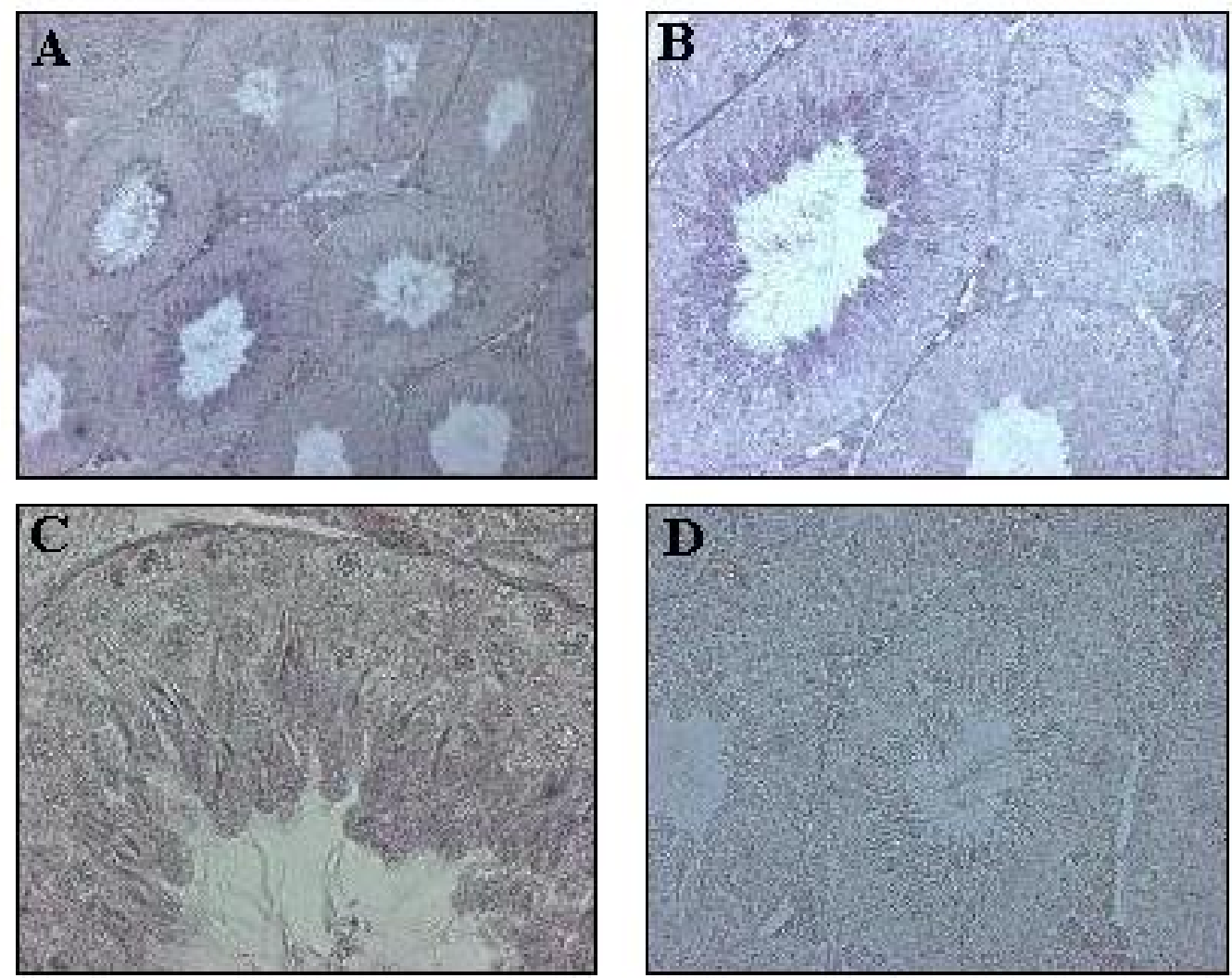

Fig. 3.15. Immunohistological Analysis of Hook1 with Testis Sections. The picture shows different aspects of testis sections recognized by $\alpha$-Hook1 antibodies. The dark purple staining indicates the positive signal of the 


\section{Results}

antibodies. The Hook1 protein is detected in round and elongated spermatids of wild type testicular tissue. The control reaction incubated with anti-goat negative serum shows no signals.

\subsubsection{Immunocytological Analysis of Hook1 with Spermatozoa}

A positive signal for Hook1 was observed in round and elongated spermatids by in situ hybridisation (3.2.4.5.), for this reason, an immunocytochemical analysis was performed in mouse spermatozoa in order to localise the Hook1 protein. Mouse spermatozoa were incubated with the purified monospecific antibody rabbit $\alpha$-Hook1, with mouse $\alpha$-tubulin as well as with the anti-goat negative serum. The spermatozoa preparations were incubated with the fluorescent anti-rabbit $\mathrm{Cy} 3$ as second antibody or anti-rabbit IgG coupled to alkaline phosphatase (which recognized $\alpha$-Hook1) and $\alpha$-mouse-FITC to couple to $\alpha$ tubulin. At the end, the preparations were covered with a drop of Vectashield (containing DAPI), which colors the nuclei blue or with Aquapolymount.

Unfortunately, no specific signal could be observed in the preparations assayed with $\alpha$ Hook1. In this case, no difference could be found between the control reaction incubated with the second antibody and the reactions done with the specific $\alpha$-Hook1 antibodies.

\subsubsection{Generation of a Hook1-GFP Fusion Protein}

In order to determine the sub-cellular localisation of the Hook1 protein, a Hook1 fusion protein with the green fluorescent protein (GFP) was generated. A northern blot with RNA of different cell lines was hybridized with a Hook1 radioactive probe (data not shown), to choose a cell line where the Hook1 protein was expressed. According to this, the 3T3 cell line was chosen. The Hook1 entire coding region was cloned in the pEGFP-C1 vector (Clontech) at the $\mathrm{C}$ terminus of the GFP using the EcoRI and KpnI restriction sites. The resulting Hook1-GFP clone was tested by sequencing and afterwards used for transfection. At $500 \mathrm{~nm}$, green fluorescent signals could be observed in the transfected cells. The green fluorescent signal was observed clearly in the cytoplasma region, but not in nucleus (Fig. 3.16.). By overlapping with the DAPI detection, this can be corroborated. Thus, Hook1 appears to be a cytoplasmic protein. Some brighter points could be observed around the nucleus, but the interpretation of these is not clear. 


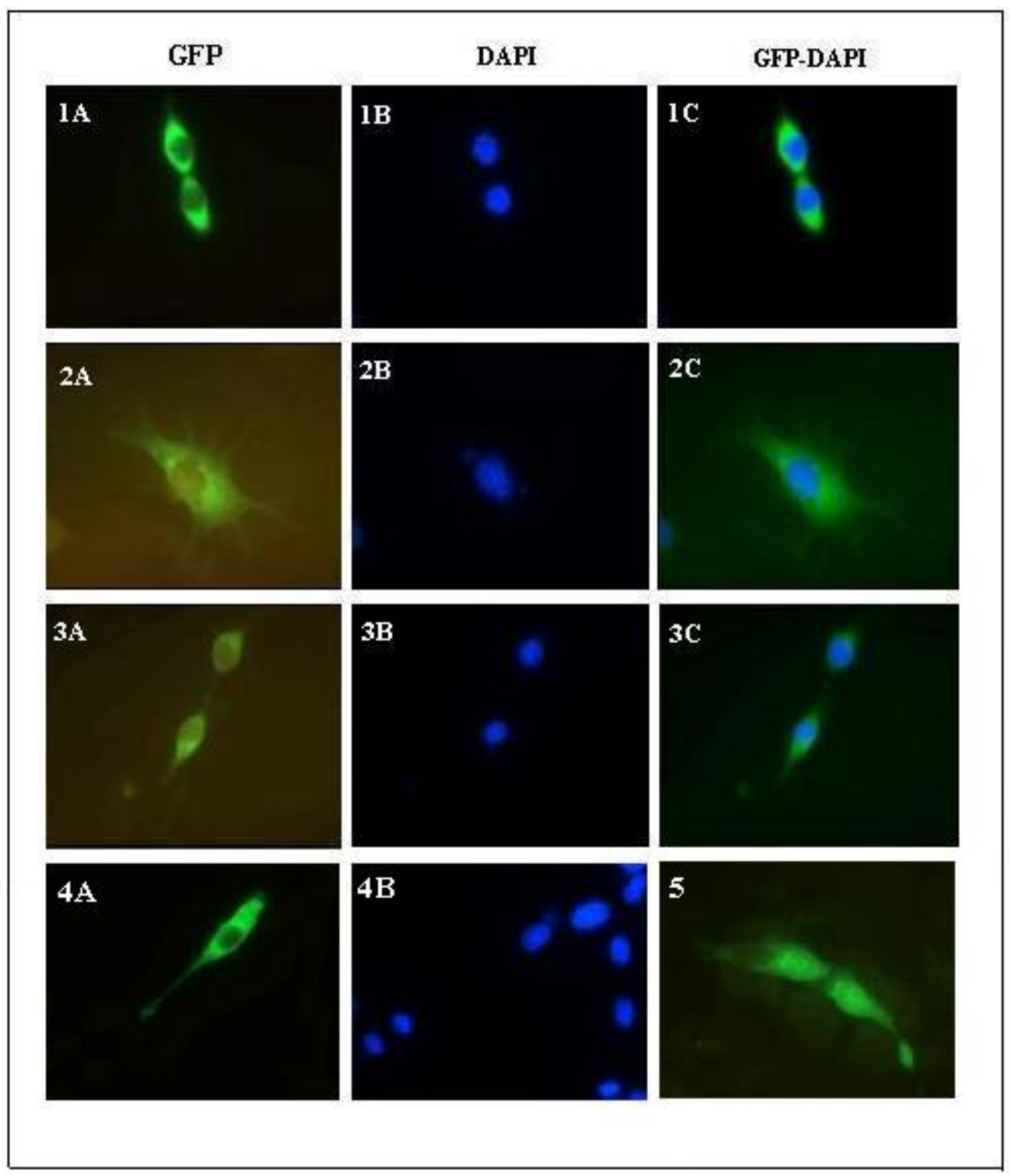

Fig. 3.16. Subcellular localisation of the Hook1-GFP fusion protein.

The figure shows 3 different aspects of the Hook1-GFP fusion protein after transfection in 3T3 mouse fibroblast cells. 1A, 2A and 3A show different cells expressing the Hook1-GFP protein. 1B, 2B and 3B show the same cells after nuclei staining with DAPI. 1C, 2C and 3C show the overlay of both the Hook1-GFP picture together with the take with DAPI. 4A and 5 are the control reaction of the 3T3 cells transfected only with the GFP vector alone. 4B is the image of the staining with DAPI from the picture 4A.

\subsection{Analysis of the azh/azh Mouse}

The mutant azh/azh is localised to the mouse chromosome 4 region $\mathrm{C} 7$ where the mouse Hook1 gene was also localised (4C5-D2). The azh/azh mouse presents an affected 
phenotype in the sperm head shape (Fig. 3.17., A-E), in the sperm head packaging of the chromatin and in the acrosomal and flagellar development (Hugenholtz AP, 1984). Therefore, as the expression of the Hook 1 gene was observed strongly in testis, this mutant mouse was analysed.

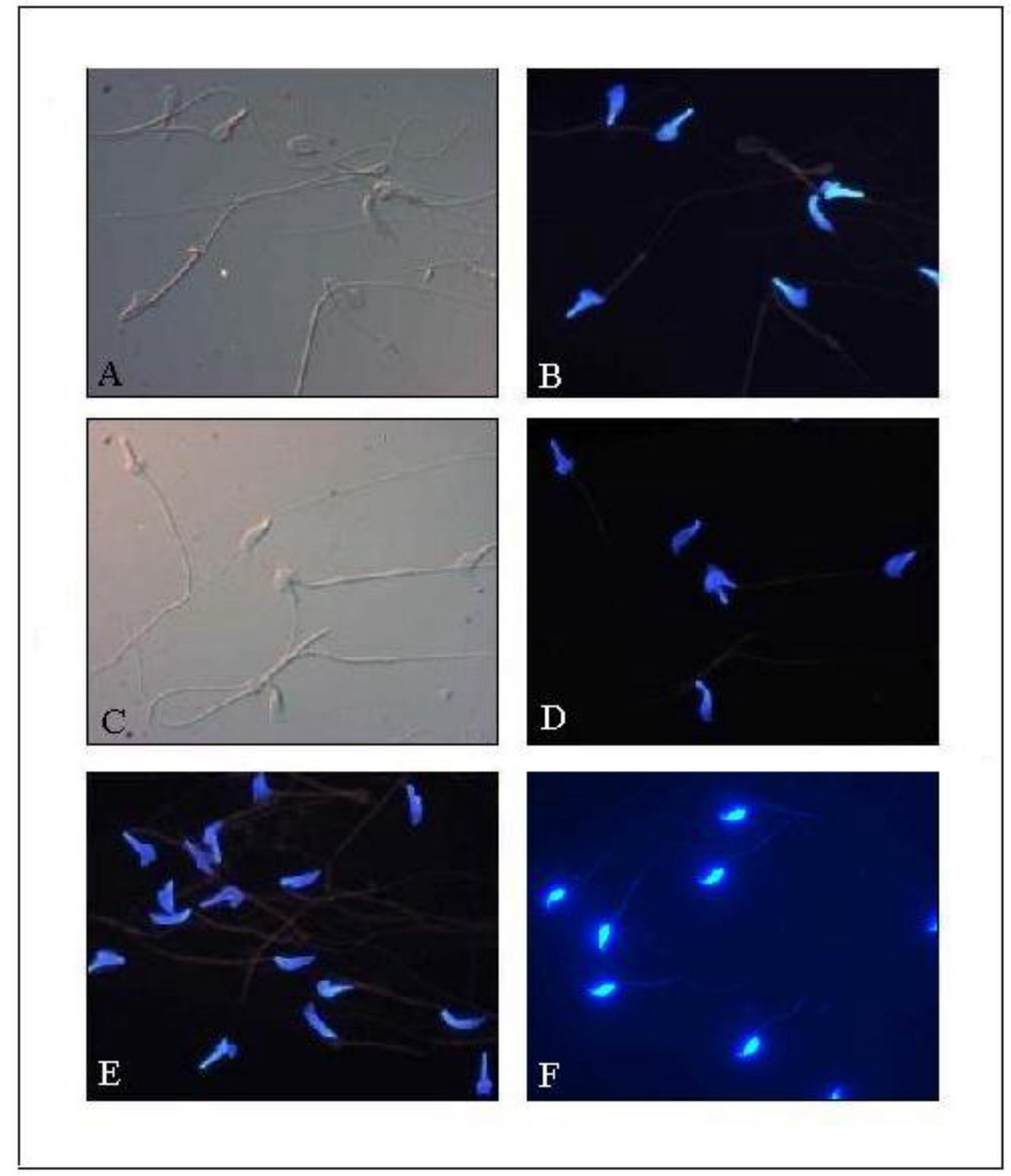

Fig. 3.17. Spermatozoa of the azh/azh mutant mouse.

A-D: Here are shown different aspects of the azh/azh mouse spermatozoa. The abnormal sperm head shape is very conspicuous, being the club shaped and the crescent the most common forms that the sperm head has in these mutant mice. A and C correspond to the phase contrast microscopy images of the spermatozoa. It can be observed the different types of sperm abnormalities such as looping midpiece. B and D show the fluorescent microscopy images of the same sperm pictures. The slides were covered with a media containing DAPI (Vectashield), which colors blue the nuclei. E: Another picture showing the nuclei of the spermatozoa of the mutant mouse. D: Control picture with the DAPI staining of the nuclei that belong to spermatozoa from a wild type mouse. 


\subsubsection{Spermatozoa of the azh/azh Mouse}

The azh/azh (abnormal spermatozoon head shape) mouse is a mutant mouse that displays an abnormal sperm head formation and shows an autosomal recessive pattern of inheritance (Hugenholtz AP, et al, 1984). Here are shown some pictures of spermatozoa examined by phase contrast and fluorescence microscopy. It can be observed the characteristic clubshaped head and the looping of the midpiece of the developing tail (Fig. 3.17., A-E).

\subsubsection{Testicular Histopathology of azh/azh Mouse}

Histological analysis of the $\mathbf{a z h} / \mathbf{a z h}$ mouse testis was performed with help of Dr. Andreas Meinhardt (Institute of Anatomy and Cell Biology, Marburg University). The azh/azh mouse was an adult 34 days postnatal. The testicular histology displayed normal interstitial cells. In $\sim 25 \%$ of the tubuli seminiferi there is an arrest of spermatogenesis at different levels, which varies from tubulus to tubulus. These arrests can be detected as follows:

1) tubuli only with Sertoli cells

2) arrest by primary spermatocytes

3) arrest by round spermatids and

4) arrest by elongated spermatids (Fig. 3.18. A).

Around $75 \%$ of the tubuli seminiferi do not present any kind of arrest, but they can have some defects in maturation of elongated spermatids. These maturation defects include only focal spermatozoa formation, decreased efficiency in the transition from round to elongated spermatids and to spermatozoa. It is remarkable the frequent production of abnormal spermatozoa head shapes (folded, with defects in nuclei condensation, crescent head shape like a half circle)(Fig. 3.18. B-C). Also, in epididymis such abnormal spermatozoa can be observed (Fig. 3.18. D). All these abnormalities in testicular histology can be clearer detected when they are compared against the normal morphology of wild type mouse testis (Fig. 3.18. E-F). 


\section{Results}
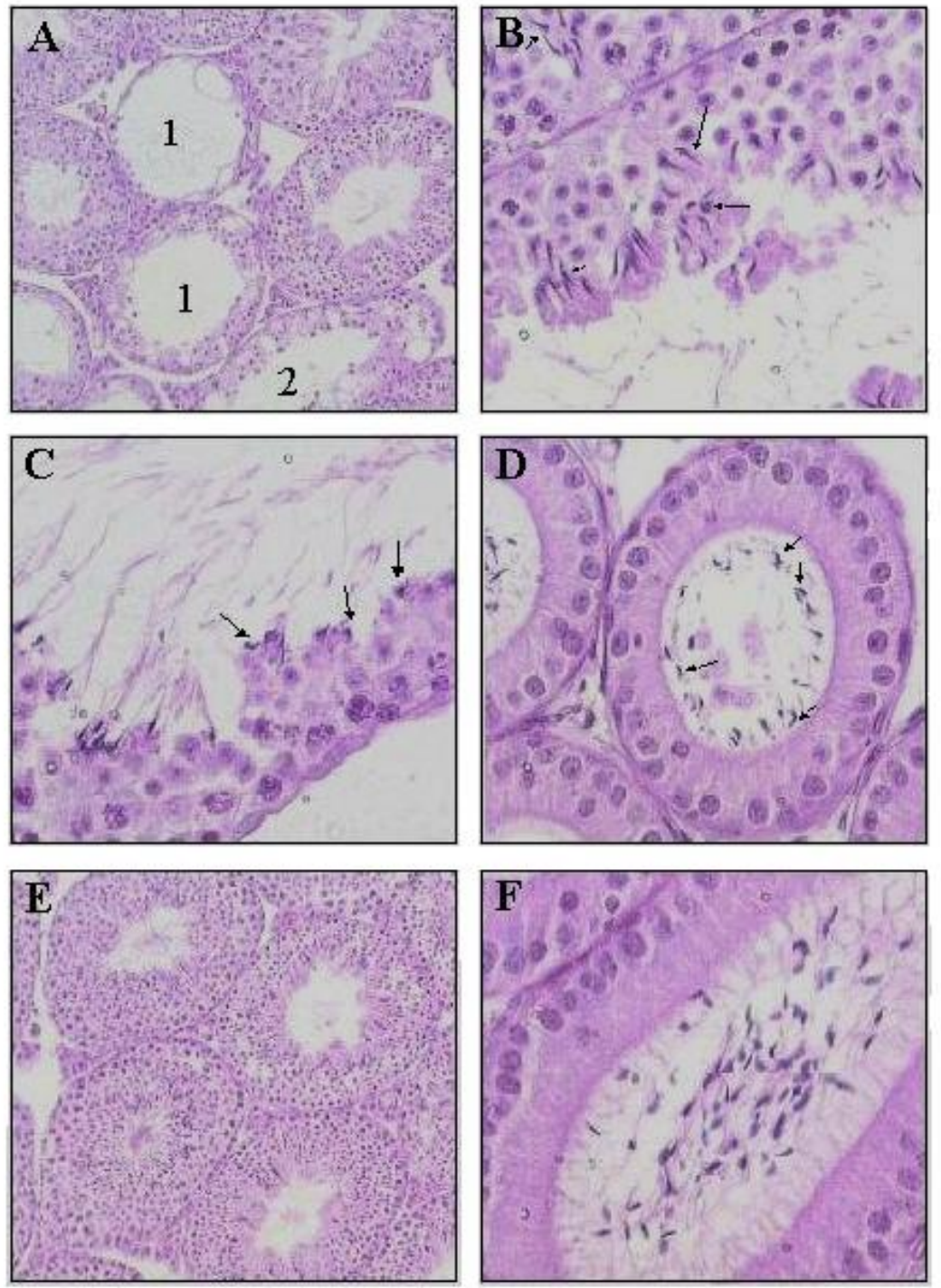

Fig. 3.18. In situ hybridization analysis of the expression of Hook1 mRNA in mouse testes of the mutant azh/azh and wild type mice.

A: The testis of the azh/azh mouse shows some abnormalities like: 1) arrest of spermatogenesis and tubuli only with Sertoli cells and 2) arrest by primary spermatocytes. These features vary from tubulus to tubulus. B-C: Enlargement showing abnormal head forming of elongated spermatids and spermatozoa. The arrows point such cases. D: Enlargement of the epididymis structure. The arrows show abnormal spermatozoa head shape in the lumen of the epididymis. E: Normal spermatogenesis in testicular tissue and normal morphology of epididymis (F) from a wild type mouse as control. 


\subsubsection{Acrosome Reaction with Wild Type and azh/azh Mice Spermatozoa}

It is well documented that all azh/azh spermatozoa display an abnormal head shape, but very less is known about the acrosome functionality. For this reason, an acrosome reaction using wild type and $\mathbf{a z h} / \mathbf{a z h}$ mutant mice spermatozoa was performed. The control reaction corresponding to wild type mouse spermatozoa (Fig. 3.19., F) shows the normal appearance of the acrosome, which can be seen as a dark slender region stained along the posterior part of the spermatozoa. The contrast between the control reaction and the acrosome reaction with wild type sperm is very clear because the spermatozoa subjected to the acrosomal reaction do not show the dark staining corresponding to the acrosome (Fig. 3.19., D-E). In this experiment, the efficiency of the acrosome reaction was of $85 \%$ wild type. Concerning azh/azh mouse, two populations of different spermatozoa can be observed: crescent-shaped and club-shaped spermatozoa.

The crescent shaped spermatozoa displayed a similar acrosome reaction efficiency as that of the wild type (85\%), whereas the club-shaped spermatozoa showed a lower efficiency of $\sim 50 \%$. Besides, an interesting feature was observed, Around 55\% of the spermatozoa showed a head pointing backward, characteristic previously observed when the azh/azh spermatozoa was subjected to any manipulation, that contrasts with the low rate of this backward pointing spermatozoa present in fresh sperm preparations $(\sim 20 \%)$.

\subsubsection{Expression Analysis of the Mouse Hook1 gene in the azh/azh Mouse}

\subsubsection{Northern Blot Analysis with RNA from the mutant mouse azh/azh}

The first step to analyse the expression of the Hook1 in the mutant mouse azh/azh was by northern blot, which was carried out with testis mRNA from wild type mouse $+/+$ and homozygous azh/azh. Twenty $\mu \mathrm{g}$ of mRNA from both testes samples were separated in a $1.2 \%$ denaturing agarose gel, transferred onto a nitrocellulose filter and radioactively hybridized at $65^{\circ} \mathrm{C}$ with the $2.4 \mathrm{~kb}$ Hook1 SalI/NotI fragment. The film after an overnight exposition to an X-ray film revealed a strong signal of Hook1 $\sim 2.4 \mathrm{~kb}$ in the wild type testis RNA and one signal $\sim 2.0 \mathrm{~kb}$ in the azh/azh mouse testis RNA (Fig. 3.20.). 


\section{Results}

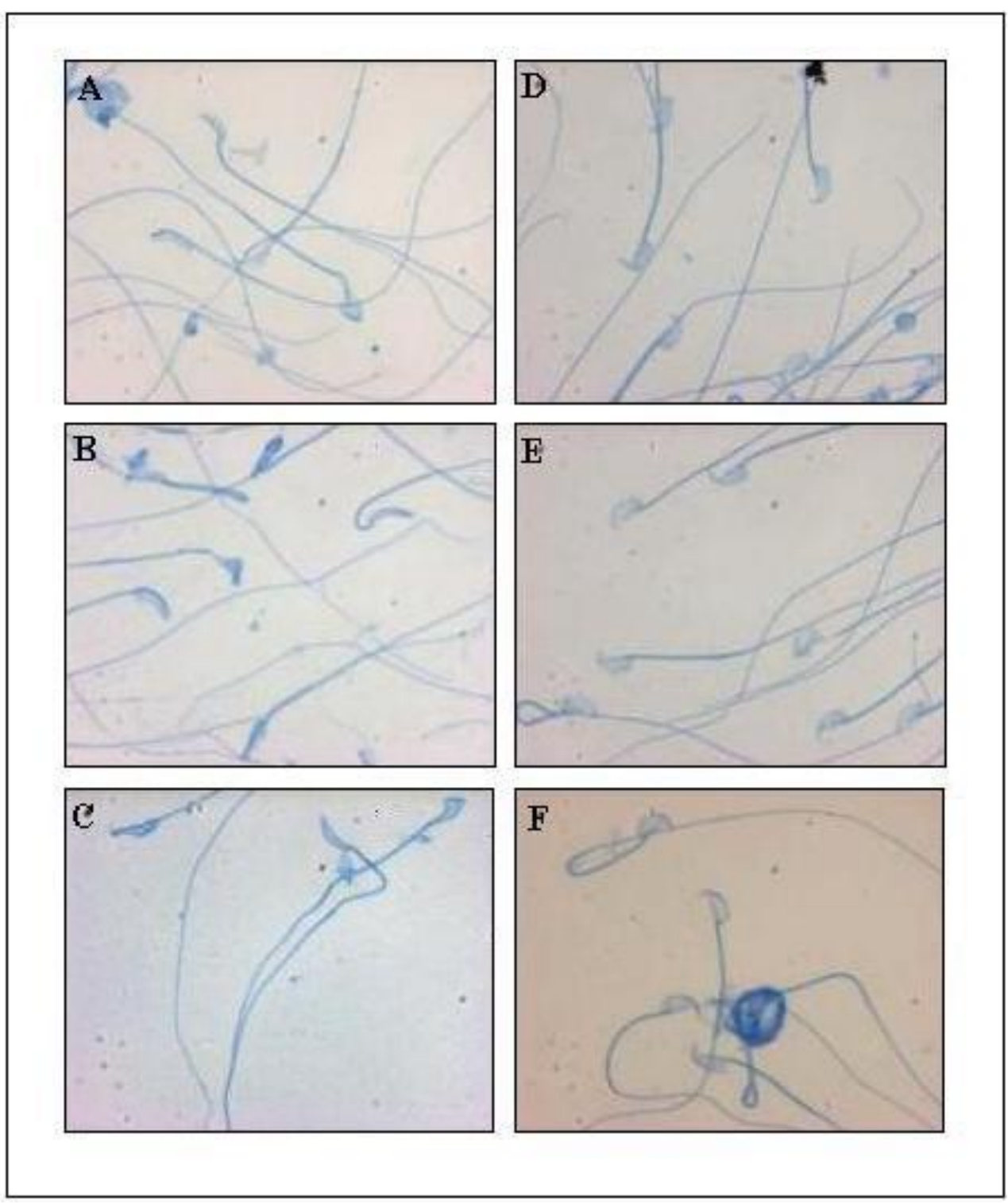

Fig. 3.19. Acrosomal reaction with wild type and azh/azh mice spermatozoa.

In this experiment, an efficiency of $85 \%$ inf the acrosome reaction was observed in the $\mathbf{a z h} / \mathbf{a z h}$ mutant spermatozoa (A-C). This rate is the same to that displayed by the wild type mouse (D-E). A-B: Aspects of the acrosome reaction with the $\mathbf{a z h} / \mathbf{a z h}$ mutant mouse spermatozoa. $\mathrm{C}$ : Control reaction with $\mathbf{a z h} / \mathbf{a z h}$, characterized by a sharp staining of the acrosome all along the posterior part of the spermatozoon. This staining is absent in the acrosome reaction. D-E: Acrosome reaction with wild type spermatozoa. F: Wild type control reaction .

This finding shows clearly how the Hook1 RNA is $\sim 0.4 \mathrm{~kb}$ shorter in the azh/azh mouse than in the wild type mouse. This event strongly supports the probability that the apparent $0.4 \mathrm{~kb}$ deletion of the Hook1 gene could be the responsible for the phenotype displayed by the $\mathbf{a z h} / \mathbf{a z h}$ mutant mouse. 


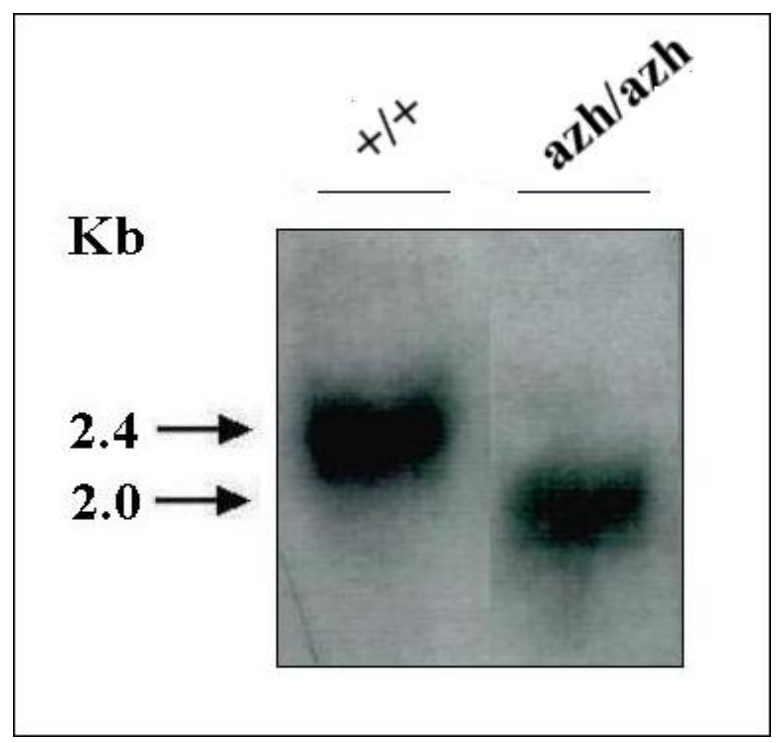

Fig. 3.20. Northern blot with azh/azh and wild type testis RNA. The figure shows northern blot analysis of wild type (+/+) and $\mathbf{a z h} / \mathbf{a z h}$ testis RNA after hybridization with the mouse Hook1 cDNA. The wild type RNA shows the expected $2.4 \mathrm{~kb}$ band. The azh/azh RNA shows amazingly a shorter transcript in testis RNA $\sim 2.0 \mathrm{~kb}$. This finding suggests that this apparent deletion could probably be responsible of the mutant phenotype in the azh/azh mouse.

\subsubsection{RTPCR of the Hook1 Gene in the azh/azh Mouse}

To continue with the expression analysis in the azh/azh mouse, RTPCR analysis was performed with testis RNA of both wild type mouse and azh/azh mouse using the primer combinations 5pPE, 5D and 9III. These combinations amplify the 5', the middle and the 3 'regions of the cDNA sequence (Fig. 3.21.).

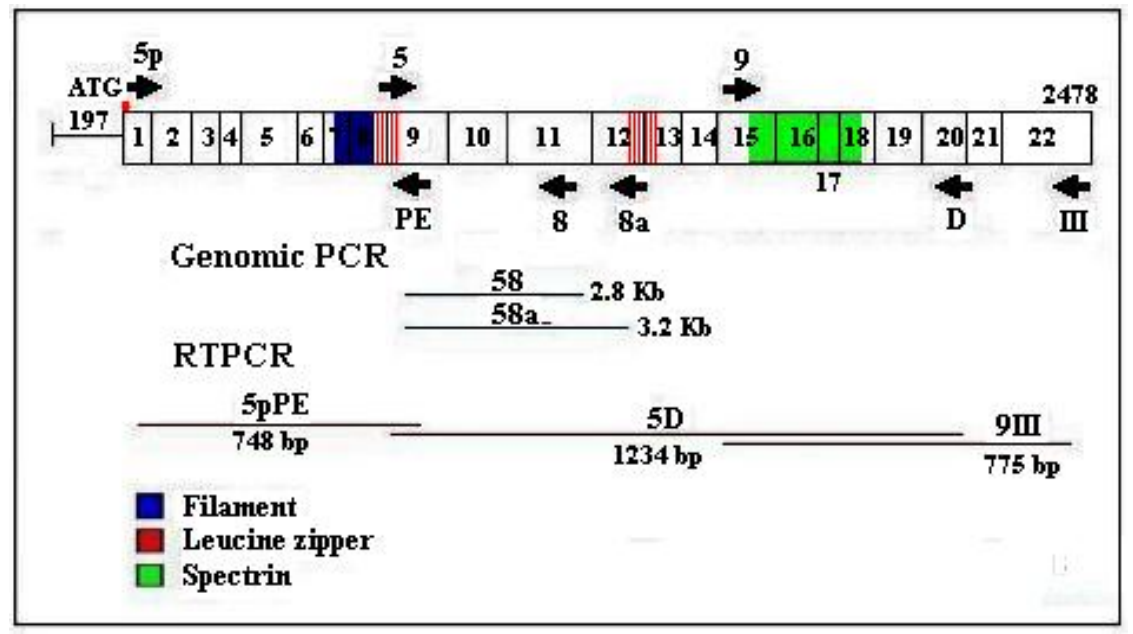

Fig. 3.21. Primers for PCR and RTPCR used to analyse the Hook1 gene with azh/azh and wild type mice. The genomic DNA of both azh/azh and wild type mice was amplified with the Hook1 gene primers 58a and 58. The primers 5 'PE, 5D and 9III were used for RTPCR. The PCR fragments and their size are shown as lines under the gene schema. 
Both RTPCR fragments for the 5'and 3'region of the cDNA had the same size $(0.8 \mathrm{~kb}$ for 5pPE and 0.9 and $0.75 \mathrm{~kb}$ for 9III) in the wild type and azh/azh RNA (Fig. 3.22.). The RTPCR with the primers $5 \mathrm{pPE}$ generated a product of $\sim 0.8 \mathrm{~kb}$. Interestingly, the primers 9III produced two fragments of $\sim 0.9$ and $\sim 0.75 \mathrm{~kb}$. According to the cDNA sequence, the expected size of the RTPCR band was 0.75 , being the band of 0.9 unexpected. Also, the 5D primer combination generated two fragments $\sim 1.4$ and $\sim 1.3 \mathrm{~kb}$ in wild type mouse RNA, the RTPCR products of $\mathbf{a z h} / \mathbf{a z h}$ with these primers (5D) were $\sim 1.0$ and $\sim 0.9 \mathrm{~kb}$, which constitutes a difference of about 400 bp (Fig. 3.21.). According to the sequence, the expected band is the $1.3 \mathrm{~kb}$ band, being the $1.4 \mathrm{~kb}$ band an unexpected band. Both extra band obtained in the 5D and 9III RTPCR reactions will be further analysed in the future.

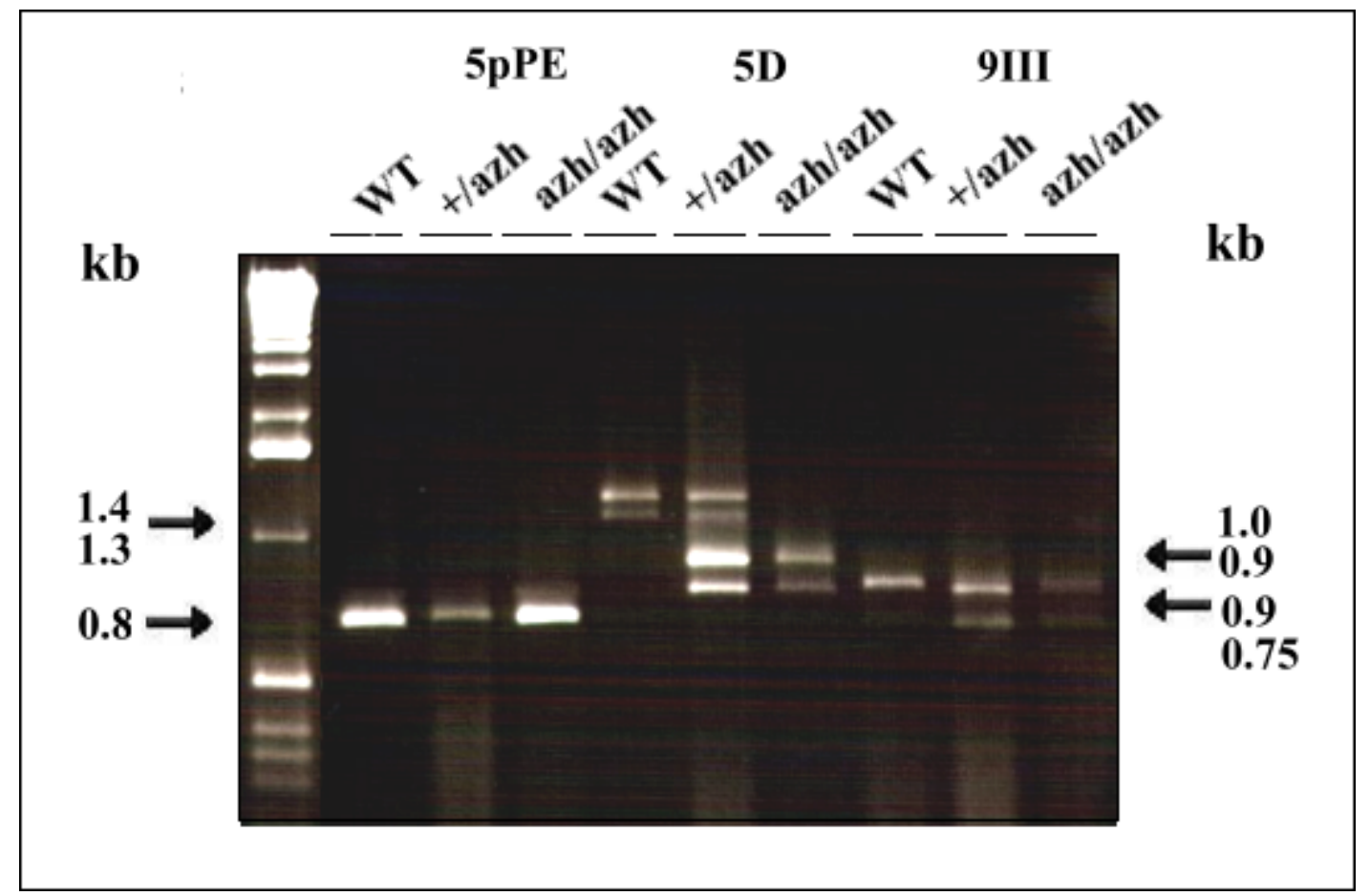

Fig. 3.22. RTPCR with wild type and azh/azh RNA.

RTPCR was performed using the primer combinations 5pPE, 5Dand 9III to amplify the $5^{\prime}$, the middle and the 3 'regions of the cDNA sequence. The combination $5 \mathrm{pPE}$ resulted in a fragment of $\sim 0.8 \mathrm{~kb}$, which had the same size with both wild type and azh/azh RNA. The primers 9III produced two fragments of $\sim 0.9$ and $\sim 0.75 \mathrm{~kb}$, also from the same size in wild type and mutant mice. The fragments obtained with the 5D primer combination in wild type mouse RNA were $\sim 1.4$ and $\sim 1.3 \mathrm{~kb}$, which showed a difference of $\sim 400 \mathrm{bp}$ when compared with the RTPCR products of azh/azh with these primers (5D), of $\sim 1.0$ and $\sim 0.9 \mathrm{~kb}$.

The 5D RTPCR fragment obtained with RNA of the azh/azh mouse was sequenced directly and a deletion comprising exons 10 and 11 of exactly $343 \mathrm{bp}$ was found (from 
nucleotide 986-1328) (Fig. 3.23), whereas the wild type sequence of the 5D RTPCR fragment showed no difference compared to the normal cDNA sequence.

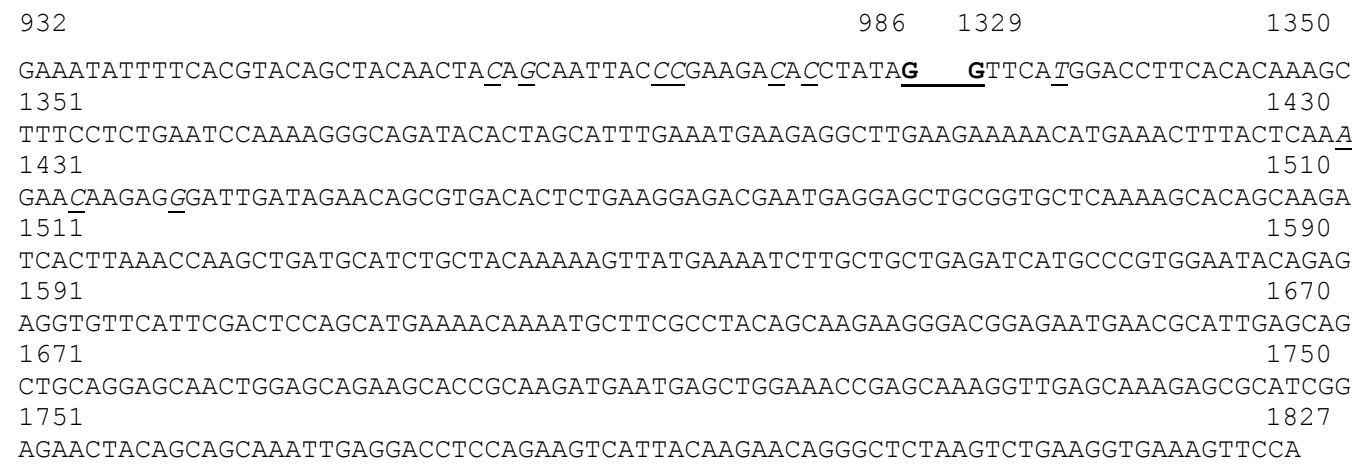

Fig. 3.23. Sequence of the RTPCR product obtained with RNA of the azh/azh mutant mouse. Here is shown the sequence of the RTPCR product of the azh/azh mouse. The RTPCR product was sequenced directly with the primer 5 used previously for the amplification. The quality sequence began from the base 932 corresponding to the cDNA and continued to the base 986, after which the base 1329 is observed. From base 1329 the sequence continues normally and the quality sequence stops by base 1827. The base 986 is the last base of exon 9 and 1329 the first one of exon 12. These exon boundaries are shown in black letter and underlined. Also, some polymorphisms along the sequence were observed, which are in cursive and underlined.

A frame shift in the ORF occurs after the deletion of these two exons (10 and 11), and the amino acid sequence presents a change from amino acid 264 and a premature stop codon in the residue 280 appears (Fig. 3.24). These results strongly suggest that the deletion of the exons 10 and 11 of the Hook1 gene, which result in a frame shift and a premature stop codon, could be responsible for the phenotype observed in the azh/azh mutant mouse.

\subsubsection{Genomic PCR of the Hook1 gene in the azh/azh Mouse}

A PCR approach was performed with DNA of the azh/azh mouse, amplifying the region around the exons 10 and 11, where the deletion was found at the RNA level. A PCR reaction using the primer combination 58a (Fig. 3.21.), which comprise exons 9-12, was performed. The fragment obtained using wild type genomic DNA was $\sim 3.4 \mathrm{~kb}$ long. The fragment obtained in the azh/azh mouse DNA was shorter of $\sim 1.2 \mathrm{~kb}$. This result shows that the $\mathbf{a z h} / \mathbf{a z h}$ mouse has a deletion of the Hook1 gene of $\sim 2.2 \mathrm{~kb}$ at the genomic level. This evidence suggests the probability that this genomic deletion can be the responsible for the mutant phenotype in the azh/azh mutant mouse. 


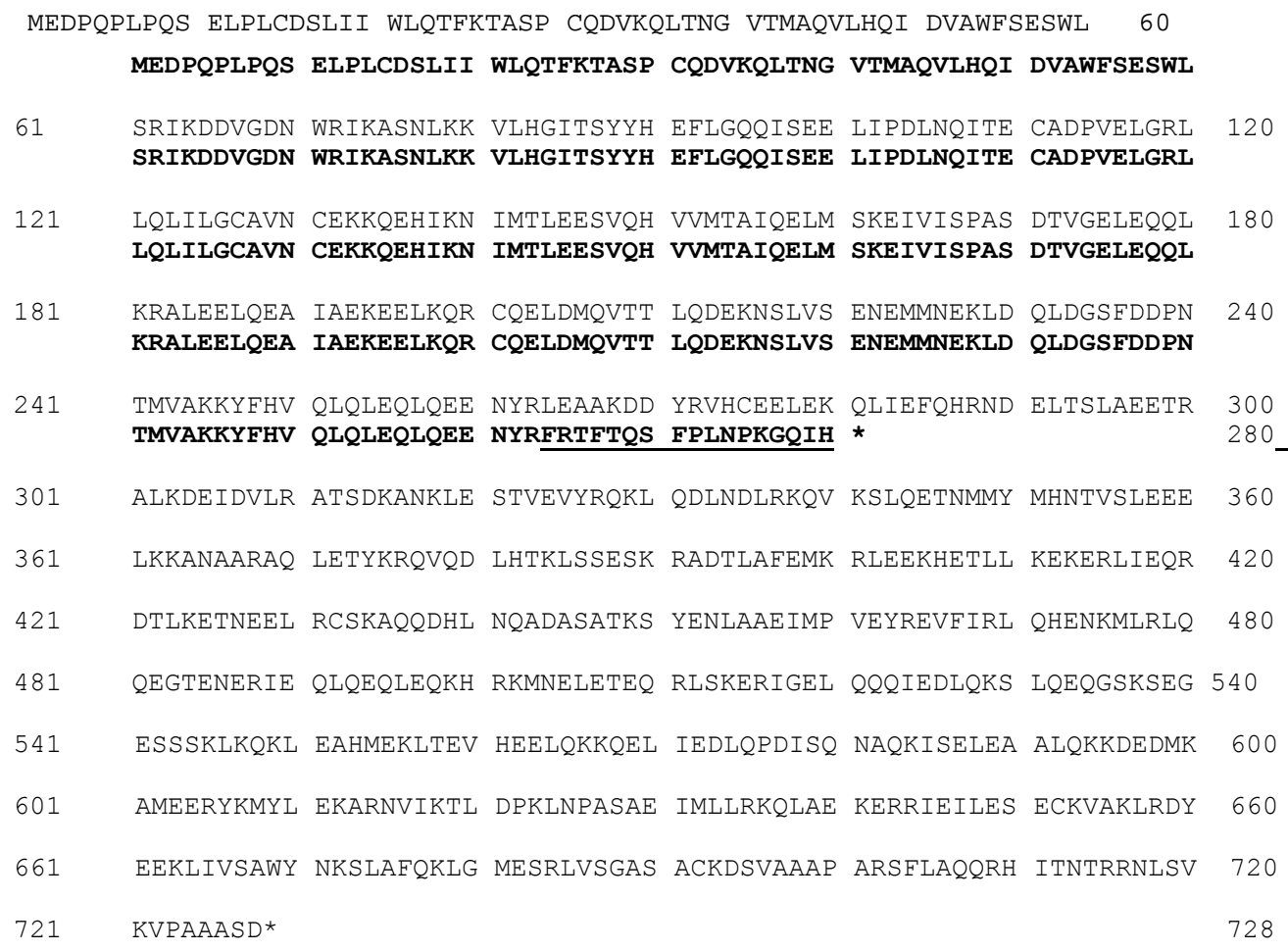

Fig. 3.24. Comparison of the Hook1 amino acid sequence between the wild type and the azh/azh mutant mice.

The wild type Hook1 amino acid sequence is 728 amino acids (aa) long. The Hook1 amino acid sequence of the $\mathbf{a z h} / \mathbf{a z h}$ mutant mouse is 280 AA long, due to a premature stop codon, which arises from a frame shift from amino acid 264 by a deletion of exons 10 and 11. The resulting mutant Hook1 amino acid sequence is truncated and can probably be responsible for the mutant phenotype in the $\mathbf{a z h} / \mathbf{a z h}$ mouse. Homozygous $\mathbf{a z h} / \mathbf{a z h}$ amino acid sequence is written in black letters and the beginning of the change in the sequence is underlined.

With the heterozygous mouse (+/azh) DNA, it was possible to amplify both 3.2 and $1.2 \mathrm{~kb}$ bands. The $3.4 \mathrm{~kb}$ band, which corresponds to the wild type allele, was much weaker than the band corresponding to the mutant allele $(1.2 \mathrm{~kb})$ or even sometimes it was impossible to be detected in the gel. Therefore, to improve and make clearer the heterozygote band detection, a further PCR reaction was performed with the primers 5 and 8 . As the primer 8 lies in exon 11, which is deleted in the azh/azh mouse DNA, the PCR product of the mutant mouse is absent, whereas the PCR fragment of wild type mouse DNA is $\sim 2.8 \mathrm{~kb}$ long. PCR with both 58 and 58a primer combinations were done in the DNA samples in order to determine the genotype. The wild type DNA $(+/+)$ shows only a band of $2.8 \mathrm{~kb}$, the heterozygous mouse DNA (+/azh) presents two bands of 2.8 and $1.2 \mathrm{~kb}$. The mutant mouse $\mathbf{a z h} / \mathbf{a z h}$ DNA shows a unique band of $1.2 \mathrm{~kb}$ (Fig. 3.25.). 


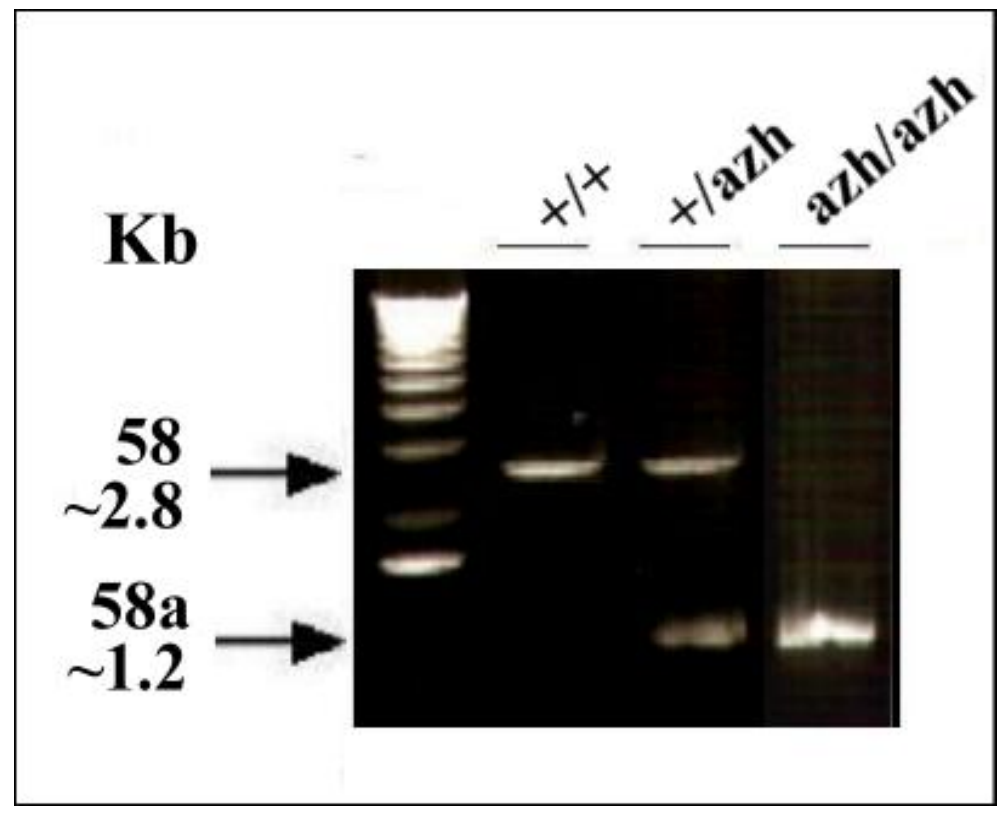

Fig.3.25. Genomic PCR with DNA of wild type, heterozygous +/azh and azh/azh mice.

The figure shows the PCR approach used to genotype the wild type, the heterozygous $+/$ - and the azh/azh mice for the Hook1 gene. The primer combinations 58a and 58 were used. The primer combination 58a amplified from exons 9-12 and gave a $1.2 \mathrm{~kb}$ PCR product in the azh allele, but the band obtained in wild type mouse DNA was almost imperceptible. Thus, the primer combination 58 was used to obtain a clear band in the wild type allele. In this case, a PCR product of $\sim 2.8 \mathrm{~kb}$ was visible only in the wild type allele, and it is absent in the azh allele, as long as the primer 8 lies in the exon 11, which is deleted in the azh allele. 


\subsection{Isolation and Characterization of the CDNA of the TSEP22 Gene}

\subsubsection{Identification of the murine TSEP22 cDNA}

In order to obtain a complete cDNA of the mouse $8 \mathrm{kDa}$ dynein light chain, a mouse testes cDNA phage library (Uni-ZAP XR, Stratagene; CD-1, 10-12 weeks old; mixed germ cells) was screened with an $8 \mathrm{kDa}$ light chain (dlc1) partial cDNA as a probe, under low stringency conditions $\left(50^{\circ} \mathrm{C}\right)$. By this means around 400,000 clones were examined. The plasmid clones were obtained by in vivo excision from the previously isolated phagemid clones. The positive clones were analysed and one of these was chosen for further analysis. It was named TSEP22 for testis specific expressed protein and because the TSEP protein has a molecular weight of $22 \mathrm{kDa}$.

\subsubsection{Nucleotide Sequence of the Mouse TSEP22}

The sequence of this clone was obtained by automatic sequencing with the primers T7 and T3. The cDNA was 657 bp long including a 63 bp 5'UTR and a 27 bp 3'UTR (Fig. 3.26.). No complete Kozak's consensus sequence was found around the initial ATG, $[\mathrm{CCA} / \mathrm{GCC}(\mathrm{ATG}) \mathrm{G}]$, but only a guanine after the ATG codon. The open reading frame (ORF) coded for a 189 AA protein. The sequence AATTTT 36 bp upstream from the stop codon can be a possible polyadenylation signal.

\subsubsection{Analysis of the Expression of the Mouse TSEP22 Gene}

\subsubsection{Northern blot Analysis of TSEP22}

In order to know the expression pattern of the TSEP22 gene, northern blot analyses were performed with $20 \mu \mathrm{g}$ of total RNA of brain, heart, lung, spleen, liver, muscle, kidney, ovary, uterus, epididymis and testis as already described. After a radioactive hybridisation with the TSEP2 $2 \mathrm{cDNA}$ at $65^{\circ} \mathrm{C}$, three different transcripts of $0.8,1.0$ and $1.4 \mathrm{~kb}$ were detected only in testicular RNA (Fig. 3.27. A). To control the RNA quantity and integrity, the northern blot was afterwards hybridized with the human elongation factor (hEF) cDNA (Fig. 3.27. B). 


\section{Results}

1 ggagagggtgggaaatgagagctcagccctagtcgagggaactgcaacctgctgtactta 60

61 gagATGGACAGCAGGCAACAGCGCCCCCAGAGGAAGACGCTACAGTGGCAGCTTGCTCAA 120 $\begin{array}{lllllllllllllllllll}M & D & S & R & Q & Q & R & P & Q & R & K & T & L & Q & W & Q & L & A & Q\end{array}$

121 GAGCAAAGACAACAGTCACCCCCACAGGGGCTTGCCGTGGCCTCCAGCCAGCCAGACACC 180 $\begin{array}{llllllllllllllllllll}E & Q & R & Q & Q & S & P & P & Q & G & L & A & V & A & S & S & Q & P & D & T\end{array}$

181 AAGAGCAAGCCTCAGGACGACTTGCAGACCCAAGACTGGGTGTGTGAGCCTCAGGAACTC 240 $\begin{array}{lllllllllllllllllllll}K & S & K & P & Q & D & D & L & Q & T & Q & D & W & V & C & E & P & Q & E & L\end{array}$

241 AgGCGCCCAGGAAGTCGCTGGAACATCAGCATCGATGAGCGCAGGCGGCTGGCCTTGCAG 300 $\begin{array}{llllllllllllllllllll}R & R & P & G & S & R & W & N & I & S & I & D & E & R & R & R & L & A & L & Q\end{array}$

301 CGTATGCAGGAGAGGACAGACACAGCCAGGGCCCCATCCGGAGACCCGCTGGGCCTGCAC 360 $\begin{array}{llllllllllllllllllll}R & M & Q & E & R & T & D & T & A & R & A & P & S & G & D & P & L & G & L & H\end{array}$

361 CCTGAGGGCCAGCAGACCGAAACTTCCCCATCGACCCAGTCTGTCCCCACCCCTCCCCTC 420 $\begin{array}{lllllllllllllllllllllllll}P & E & G & Q & Q & T & E & T & S & P & S & T & Q & S & V & P & T & P & P & L\end{array}$

421 CAgGCCTGTGAGACTATGGCTGATCCCCTGCAGGACATCGCGCATGTGTTGGCCGAGCTG 480 $\begin{array}{llllllllllllllllllll}Q & A & C & E & T & M & A & D & P & L & Q & D & I & A & H & V & L & A & E & L\end{array}$

481 ATGTCTGAGGgTGTAGAGAGAGATGTACTCATTTCTCAGCCTCTAAGATCTACCGAGAAT 540 $\begin{array}{lllllllllllllllllllllllll}M & S & E & G & V & E & R & D & V & L & I & S & Q & P & L & R & S & T & E & N\end{array}$

541 TTтAATGCCTTCCAGGACTTTTTGGCCCAGGACGCGCCTCTTTGGAAGGATGAGAATTTT 600 $\begin{array}{llllllllllllllllllll}\mathrm{F} & \mathrm{N} & \mathrm{A} & \mathrm{F} & \mathrm{Q} & \mathrm{D} & \mathrm{F} & \mathrm{L} & \mathrm{A} & \mathrm{Q} & \mathrm{D} & \mathrm{A} & \mathrm{P} & \mathrm{L} & \mathrm{W} & \mathrm{K} & \mathrm{D} & \mathrm{E} & \overline{\mathrm{N}} & \mathrm{F}\end{array}$

601 GAGGCCCAGACCTCAAGATGGCCTCACTCCTAAgaagcagctttgctcagcCC 653 $\begin{array}{llllllllllll}E & A & Q & T & S & R & W & P & H & S & *\end{array}$

Fig. 3.26. Nucleotide sequence of the TSEP22 cDNA.

The amino acid sequence is shown below the nucleic acid sequence. The putative start (ATG) and stop (TAA) codons are highlighted. No typical polyadenilation signal was found, but the sequence AATTT at 36 bp upstream from the stop codon can be a possible atypical polyadenilation signal. No complete Kozak's consensus sequence was found around the initial ATG, (CCA/GCC(ATG)G, but only a guanine after the ATG codon.

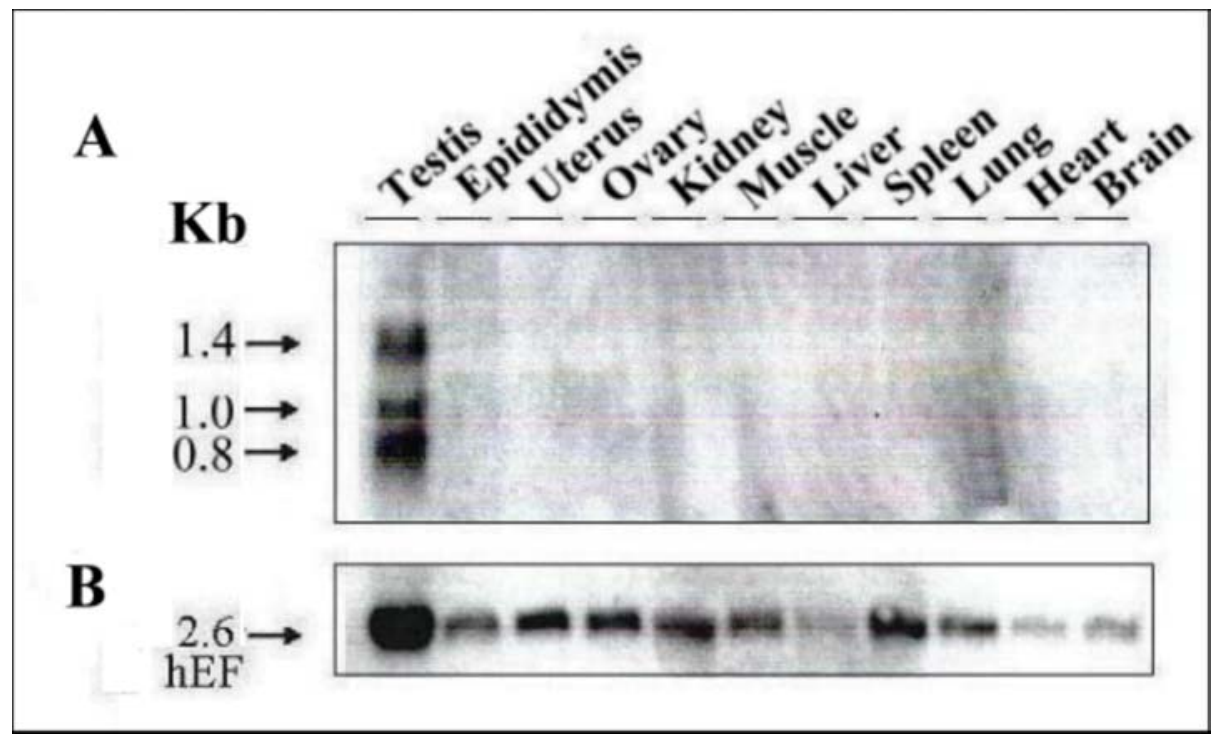

Fig. 3.27. Northern analysis of the expression of TSEP22 with RNA from mouse adult tissues.

The 657 bp TSEP22 cDNA was used as probe to hybridize $20 \mu \mathrm{g}$ of total RNA isolated from various mouse tissues. A: transcripts of $0.8,1.0$ and $1.4 \mathrm{~kb}$ could be observed only in testis. B: Hybridisation with the human elongation factor cDNA (hEF), to verify RNA concentration and quality. 
As long as three transcripts were detected, RNA was handled with RNase $\mathrm{H}$ to exclude that the bigger transcripts were due to variations in the polyadenylation. For this, $20 \mu \mathrm{g}$ of testis RNA were treated with RNase $\mathrm{H}$ to remove the polyadenylation tails. The treated RNA together with intact RNA as a control were separated electrophoretically, transferred onto a membrane and hybridized with the radioactively labeled TSEP22 cDNA probe. The result indicated that even after the RNase treatment, at least three different shorter transcripts could be detected (Fig. 3.28).

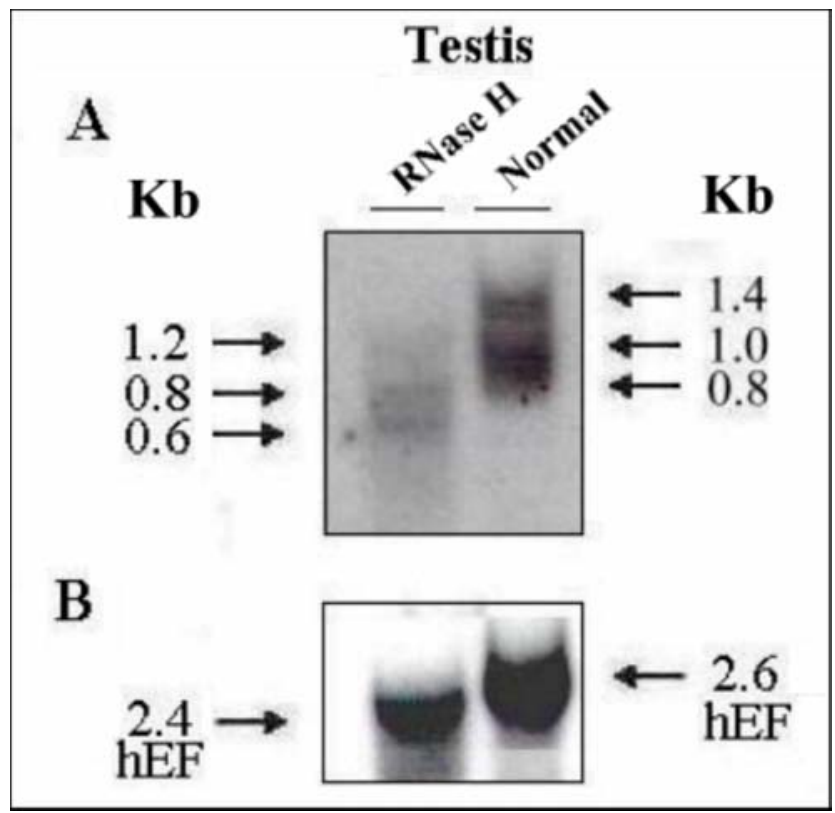

Fig. 3.28. Northern analysis of the expression of TSEP22 with digested and undigested mouse testis RNA with RNase $H$.

The 657 bp TSEP22 cDNA was used as probe to hybridize $20 \mu \mathrm{g}$ of adult testis RNA restricted (1) and unrestricted (2) with RNase $\mathrm{H}$. A: the normal transcripts of $0.8,1.0$ and $1.4 \mathrm{~kb}$ could be observed in the unrestricted testis sample (2), whereas three transcripts $\sim 200 \mathrm{bp}$ smaller than in the unrestricted RNA (0.6, 0.8 and $1.2 \mathrm{~kb}$ respectively) could be detected in the testis RNA restricted with RNase H (1). B: Hybridisation with the human elongation factor cDNA (hEF) also shows the difference $\sim 200$ bp between the restricted and unrestricted RNA samples.

Due to the testis specific nature of the transcripts detected with the TSEP22 cDNA, mRNA from different mutant mice with defects in different stages of spermatogenesis was analysed, to determine in which spermatogenesis stage these transcripts are present. Strong signals could be detected in strains containing postmeiotic germ cell stages such as olt/olt and $\mathrm{qk} / \mathrm{qk}$ (arrest in early spermatids and elongated spermatids respectively), as well as weak signals in the strains that present only premeiotical germ cells (Tfm/Y and Ley-IL-/-, 
arrest in primary spermatocytes). No transcripts were observed in mutants presenting only somatic cells and no germ cells $\left(\mathrm{W} / \mathrm{W}^{\mathrm{v}}\right)($ Fig. 3.29.).



Fig. 3.29. Northern blot with mouse mutant testicular RNA.

Testicular RNA of different mutant (W/W $/ \mathrm{W}^{\mathrm{v}}$, LeyIL-/-, Tfm/Y, olt/olt and qk/qk) and wild type mice were hybridised with the $657 \mathrm{bp}$ TSEP $22 \mathrm{cDNA}$ as a specific probe. A: The three transcripts previously found with the TSEP22 cDNA could be observed in the wild type testis as well as in the strains containing postmeiotic germ cell stages, such as olt/olt and qk/qk. No transcripts were detected in the rest of the mutant mice, which have only somatic cells and no germ cells $\left(\mathrm{W} / \mathrm{W}^{v}\right)$ or only premeiotical germ cells ( $\mathrm{Tfm} / \mathrm{Y}$ and LeyIL-/-). B: Hybridisation with the human elongation factor cDNA (hEF) to check the quality and quantity of RNA.

Also, the distribution of the TSEP22 transcript in different testicular developing stages at distinct levels of spermatogenesis was determined due to the testis-specific nature of the TSEP22 previously detected To achieve this, northern blot analysis with mRNA from developing postnatal testes was performed using the TSEP22 cDNA as a probe. All three transcripts detected previously with testis RNA could be detected in testicular RNA from postnatal day 15. This finding indicates that the expression of the gene starts in primary spermatocytes (Fig. 3.30.).

All the northern membranes were subjected afterwards to a hybridisation with the hEF probe to control the quantity and integrity of the RNA. 


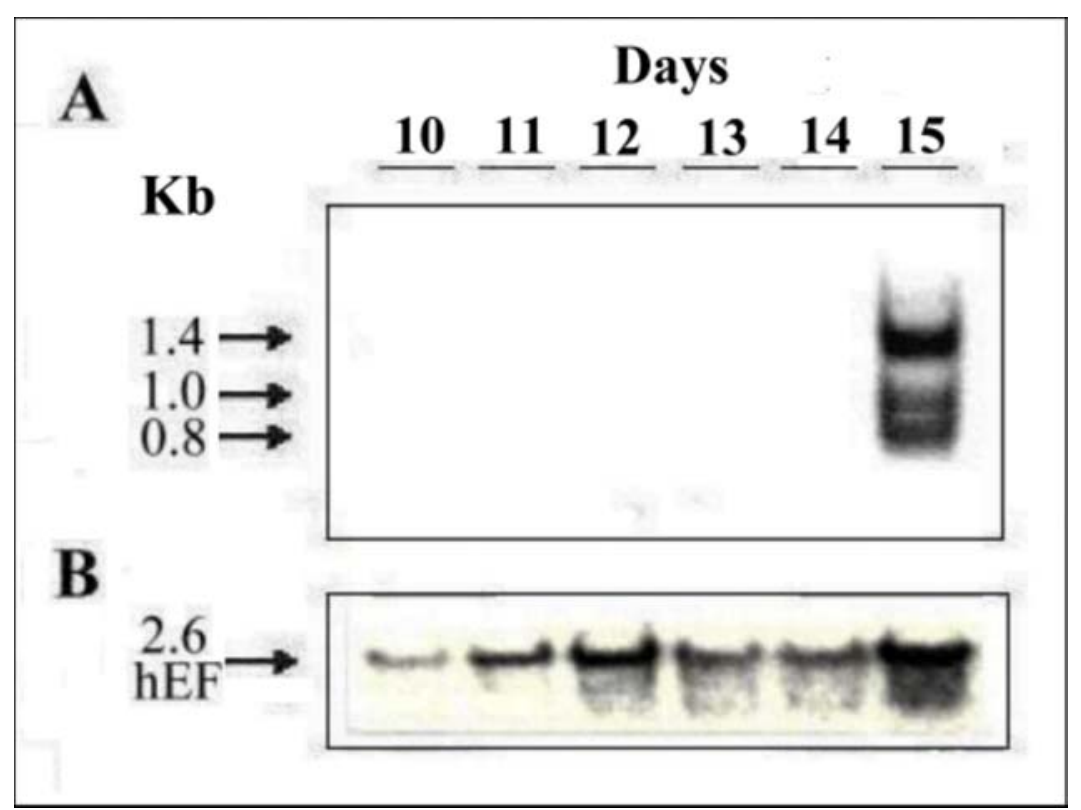

Fig. 3.30. Northern analysis of the expression of TSEP22 in different developing stages of mouse testis.

The film shows the hybridisation of a radioactive labeled probe containing the TSEP 22 cDNA with 20 $\mu \mathrm{g}$ of total RNA isolated from different mouse testis development stages from postnatal day 10-15, under conditions of high stringency. A: the three characteristic TSEP22 transcripts could be detected in testis from postnatal day 15. B: Hybridisation with the human elongation factor cDNA (hEF).

\subsubsection{TSEP22 In situ Hybridisation with Testis Sections}

In situ hybridisation with testis paraffin sections from adult wild type mouse $(7 \mu \mathrm{m}$ cut width) was performed to identify which germ cell types were involved in the testicular expression of TSEP22. As a probe, the linearized plasmid comprising the TSEP22 cDNA sequence labeled with DIG-rUTP via in vitro transcription was used. After the "sense" and "antisense" probes were tested by dot blot with dilutions from 1:100-10.000 and detected with an anti-DIG antibody coupled with alkaline phosphatase, they were employed for the in situ hybridisation in testis sections. TSEP22 transcripts could be detected from early spermatocytes to spermatids with the antisense probe (Fig. 3.31. A-C). In the sense control, no signals were observed (Fig. 3.31. D). 


\section{Results}

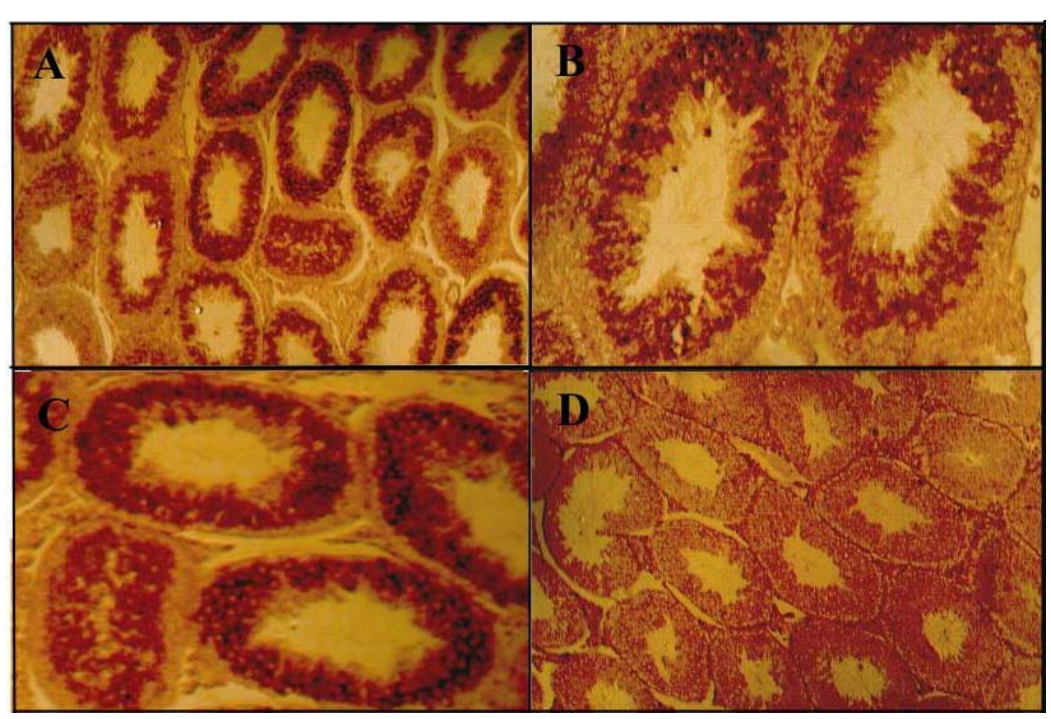

Fig. 3.31. TSEP22 in situ hybridisation.

The expression of TSEP22 was examined in adult mouse testis by in situ hybridisation. A-C: A positive signal was detected from early spermatocytes to spermatids with the DIG labeled TSEP22 specific probe.The sense probe yielded no signals (D).

\subsubsection{Isolation of Transcripts Homolog to the TSEP22 cDNA}

TSEP22 codes for at least three testis specific transcripts of $1.4,1.0$ and $0.8 \mathrm{~kb}$ according to the northern blot analysis. As long as the TSEP22 cDNA sequence obtained in the initial library screening was very short (657 bp) to correspond to the size of the transcripts, it was necessary the search for longer cDNA clones.

The isolation of new cDNA clones for TSEP22 was done by screening an RZPD (Ressource Zentrum Primäre Datenbank des deutschen humanen Genomprojectes, Max Planck-Institut für molekulare Genetik, 14059 Berlin) mouse testes cDNA library consisting of 3 filters with the 657 bp TSEP 22 cDNA as a ${ }^{32} \mathrm{P}$-dCTP-labelled probe under high stringency conditions $\left(65^{\circ} \mathrm{C}\right)$. By this approach, 82,944 clones were screened and 15 cDNA clones contained in the vector pSport 1 were obtained. The clones obtained by this screening were digested with the enzymes BamHI and EcoRI to cut out the insert, and with the enzymes PstI and XbaI to check if the clones comprised the complete TSEP22 sequence, which contained both enzymes restriction sites. Four cDNAs clones were chosen for sequencing on the basis of their restriction pattern and size

The TSEP22 sequence from cDNA base 25 until polyA tail, that is $627 \mathrm{bp}$ long (named "E”), was similar to all five clones. It contains the beginning of the ORF to the 3 'UTR. The 
5 'region of the clones was very variable (Fig. 3.32.). The 24 bp 5 'region of the TSEP22 cDNA was defined as "B".

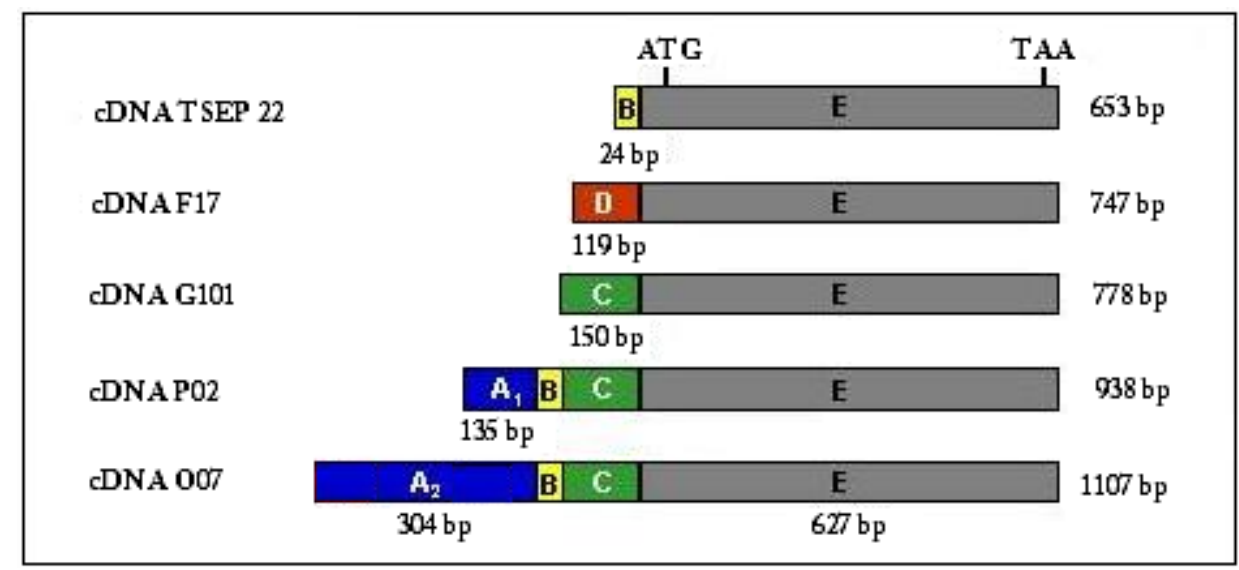

Fig. 3.32. Sequence similarity of the different TSEP cDNAs.

The different TSEP22 cDNAs found were grouped by block sequences that show similarity among them. These sequences in block are depicted as $\mathrm{A}_{1}, \mathrm{~A}_{2}, \mathrm{~B}, \mathrm{C}, \mathrm{D}$ and $\mathrm{E}$. They are represented with different colors. It can be observed the 3 'constant region and that the variability among the different cDNAs sequences lies in the 5 'region.

The clone identified as F17 was $747 \mathrm{bp}$ long and had a 5'sequence of $119 \mathrm{bp}$ defined as "D", which was totally different from B. The clone P02 was 938 bp and had a mixed 5 'region sequence, which contained B (5'sequence from TSEP22) between two sequences of $135 \mathrm{bp}\left(\mathrm{A}_{1}\right)$ and $150 \mathrm{bp}(\mathrm{C})$ respectively. The clone G101 was $778 \mathrm{bp}$ long and contained the sequences $\mathrm{C}$ and $\mathrm{E}$. The clone $\mathrm{O} 07$ was 1109 bp long and was very similar to P02, but contained a proximal sequence $65 \mathrm{bp}$ longer to that of P02, $304 \mathrm{bp}$ long in total, which was named $\mathrm{A}_{2}$. The length of these clones was compatible to that of the different transcripts obtained by the RNase $\mathrm{H}$ experiments. The sequences corresponding to these different clones are included in Appendix.

In order to prove if the different clones correspond effectively to different transcripts, the variable 5'sequences $\mathrm{A}_{2}, \mathrm{C}, \mathrm{D}$ and $\mathrm{E}$ were amplified by PCR, radioactively labeled and hybridized separately to a northern blot membrane containing four lanes of $20 \mu \mathrm{g}$ of testis RNA each (Fig. 3.33.). 


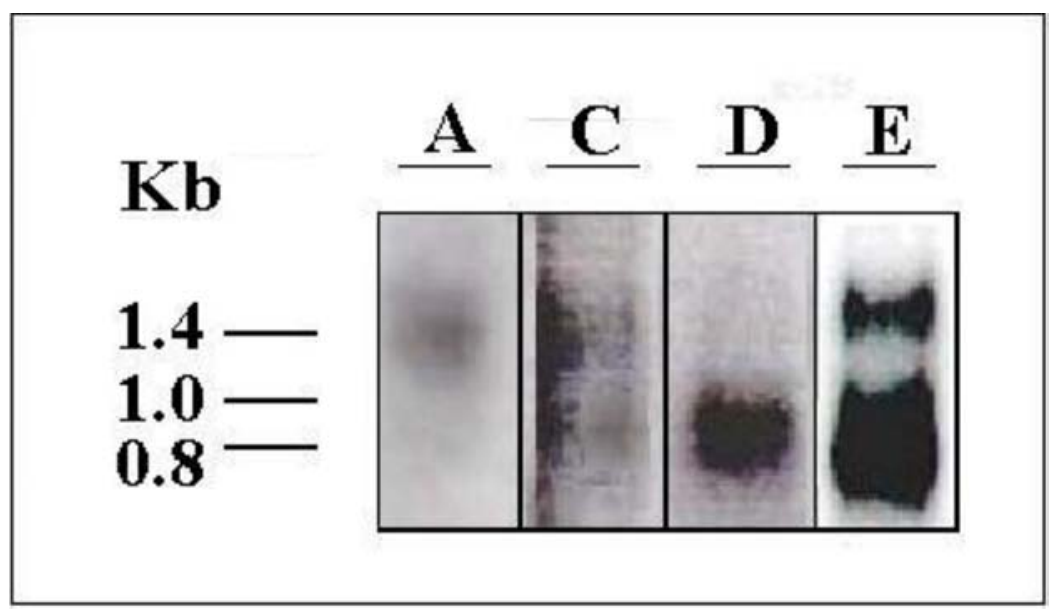

Fig. 3.33. Northern blot with mouse testis RNA hybridized with 4 different TSEP22 cDNA sequence probes.

The film shows the hybridisation of 4 radioactive labeled probes containing different regions of the TSEP22 cDNAs with $20 \mu \mathrm{g}$ of adult mouse testis RNA. The probes A, C, D and E correspond to the sequences already summarized in fig. 3.31. It can be observed that the hybridisation with sequence $\mathrm{E}$ shows all three bands obtained with the $653 \mathrm{bp}$ cDNA. The sequence D gives a signal of $1 \mathrm{~kb}$. Sequence $\mathrm{C}$ gives positive signals for the 1.4 and $1.0 \mathrm{~kb}$ transcripts and sequence $\mathrm{A}$ yields a $1.4 \mathrm{~kb}$ signal.

The probe $A_{2}$ gave a hybridisation signal of around $1.4 \mathrm{~kb}$. In this case, it was not possible to see if there were one or two transcripts (regarding the existence of two transcripts, P02 and $\mathrm{O} 07$ with the sequences $\mathrm{A}_{1}$ and $\mathrm{A}_{2}$ ) due to the condition of the gel where the RNA was separated $(2.5 \%$ denaturating agarose gel). Thus, the presence of a different transcript (P02) to $\mathrm{O} 07$ remains to be elucidated. The probe $\mathrm{C}$ was positive for two transcripts of around 1 and $1.4 \mathrm{~kb}$, congruent with the information obtained from the sequences for the clones G101, P02 and O07. The probe D showed a transcript of around $1.0 \mathrm{~kb}$. Finally, the probe E that was constant in every clone including TSEP22, was positive for the original three transcripts of around $0.8,1.0$ and $1.4 \mathrm{~kb}$.

These results show that the coding region of the TSEP22 gene is present in at least 4 different transcripts. This event can be due to an alternative splicing that gives place to the different transcripts, although a multicopy gene theory cannot be ruled out. Only the elucidation of the genomic structure will clear this matter. 


\subsection{Genomic Analysis}

\subsubsection{Isolation of Mouse Genomic Cosmid Clones}

A mouse genomic DNA clone is necessary to analyse the genomic structure of the gene and to generate genomic probes for the chromosomal localisation. For this reason, the screening of an RZPD mouse genomic DNA cosmid library was done. The mouse genomic DNA cosmid library consists of 11 filters and it was hybridized with the TSEP22 DNA probe under high stringency conditions $\left(60^{\circ} \mathrm{C}\right)$.

From the positive clones obtained by this approach, two different cosmid clones were chosen for further analysis: clones 2112 and 1277.

\subsubsection{TSEP22 Genomic Analysis}

\subsubsection{Analysis of the TSEP22 Cosmid Clones}

The mouse genomic DNA cosmid clones 2112 and 1277 showed different restriction patterns with BamHI. Therefore, a PCR analysis approach was designed in order to identify the TSEP22 gene sequence present in the cosmid clones. This approach was based on the different sequence blocks found in the cDNA clones (Fig. 3.31.). According to this, five different PCR products could be identified: the primer combination P1-36RRT amplified from sequence B to the 3 'region of sequence E. P2-36RRT amplified from the 3 'region of sequence $\mathrm{A}_{2}$ to the 3 ' of E. P3-36RRT comprised from the 5'region of $\mathrm{A}_{2}$ to end of E. P436RRT amplified from sequence D to E and P5- amplified a small part in the middle of sequence E (Fig. 3.34.).

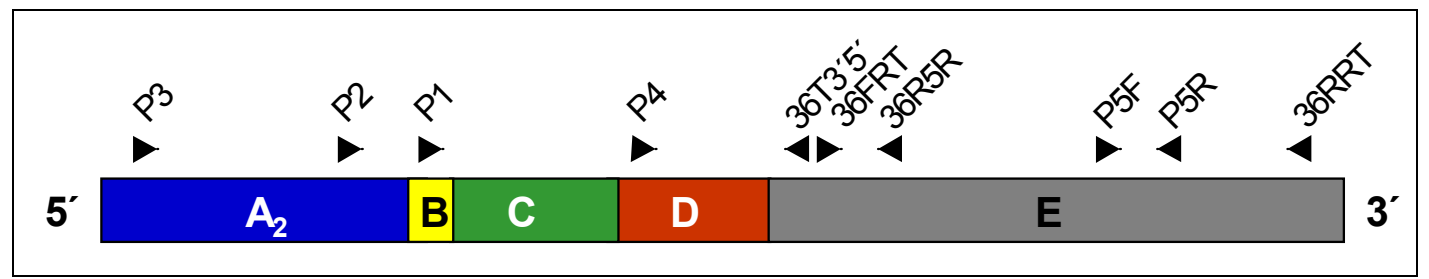

Fig. 3.34. Distribution of the PCR primers along the TSEP22 cDNA sequence.

Here is shown the localisation of the different primers in the TSEP22 cDNA sequence designed to analyse the mouse genomic DNA cosmid clones. The arrows indicate the location and direction of the primers in the cDNA sequence. 
After performing the five different PCR reactions (P1, P2, P3; P4 and P5) with the DNA of the two cosmid clones (1277 and 2112), it was found that the cosmid 2112 contained almost the complete sequence corresponding to the cDNA clone 007 which had the longest cDNA sequence (Fig. 3.35).

Only a short sequence on 3 'region of E was absent. As long as the PCR products P1, P2 and P3 were longer around $100 \mathrm{bp}$ of expected, an intron of $103 \mathrm{bp}$ between the sequence blocks $\mathrm{C}$ and $\mathrm{D}$ could be deduced by sequencing. The cosmid 1277 proved to have only a part of sequence $\mathrm{E}$.

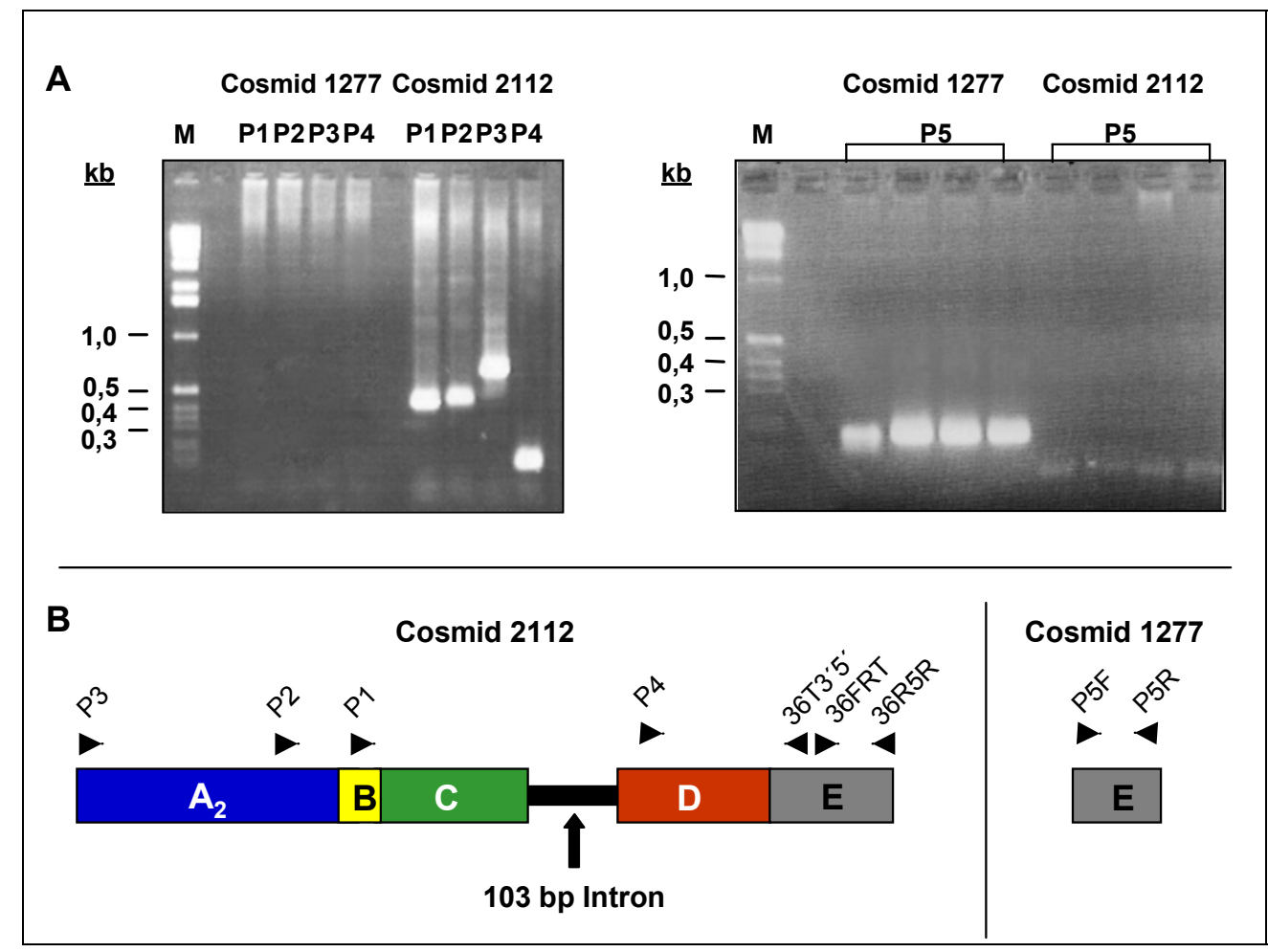

Fig. 3.35. PCR analysis of the cosmids 1277 and 2112.

In this figure, the agarose gels with the PCR products of the cosmids 1277 and 2112 are shown. A: PCR products obtained with the forward primers $\mathrm{P} 1$ to $\mathrm{P} 4$ and the reverse primer $36 \mathrm{~T} 35^{\prime}$ with both cosmids. It can be observed that these primer combinations yield some bands of around 0.6 and $0.5 \mathrm{~kb}$ in cosmid 2112 and no bands in cosmid 1277. When the primer pair 5F/P5R are used, a $0.1 \mathrm{~kb}$ band can be seen with the cosmid 1277, whereas no band is detectable with the cosmid 2112. This PCR product corresponds to the size of the cDNA meanwhile the length of the PCR products obtained with the forward primers P1, P2 and P3 were bigger. This is due to a 103 bp intron found by sequencing between the sequence blocks $\mathrm{C}$ and $\mathrm{D}(\mathrm{B})$. 


\subsubsection{Southern blot Analysis and Copy Gene Determination}

A restriction analysis of TSEP22 in mouse genomic DNA was performed and compared with the restriction patterns obtained with the cosmid clones. For this, $20 \mu \mathrm{g}$ of mouse male genomic DNA were restricted with BamHI, EcoRI, and XbaI, separated in an horizontal gel and blotted to a nitrocellulose membrane. The filter was hybridized with the $657 \mathrm{bp}$ TSEP2 2 cDNA at $65^{\circ} \mathrm{C}$. The band pattern obtained in the mouse genomic DNA Southern blot was compared to those of the mouse cosmid clones (Fig. 3.36.). In this case, the genomic DNA restriction pattern can be explained by the addition of the bands from both cosmid clones. Even though, there are some differences observed in the BamHI restriction, like the $6 \mathrm{~kb}$ band present in the genomic DNA that cannot be found in the cosmid clones. Also, a $12 \mathrm{~kb}$ band of the cosmid clone 2112 is not present in the genomic DNA pattern. An incomplete digestion explains the unclear bands obtained in the genomic DNA restriction with $\mathrm{XbaI}$.

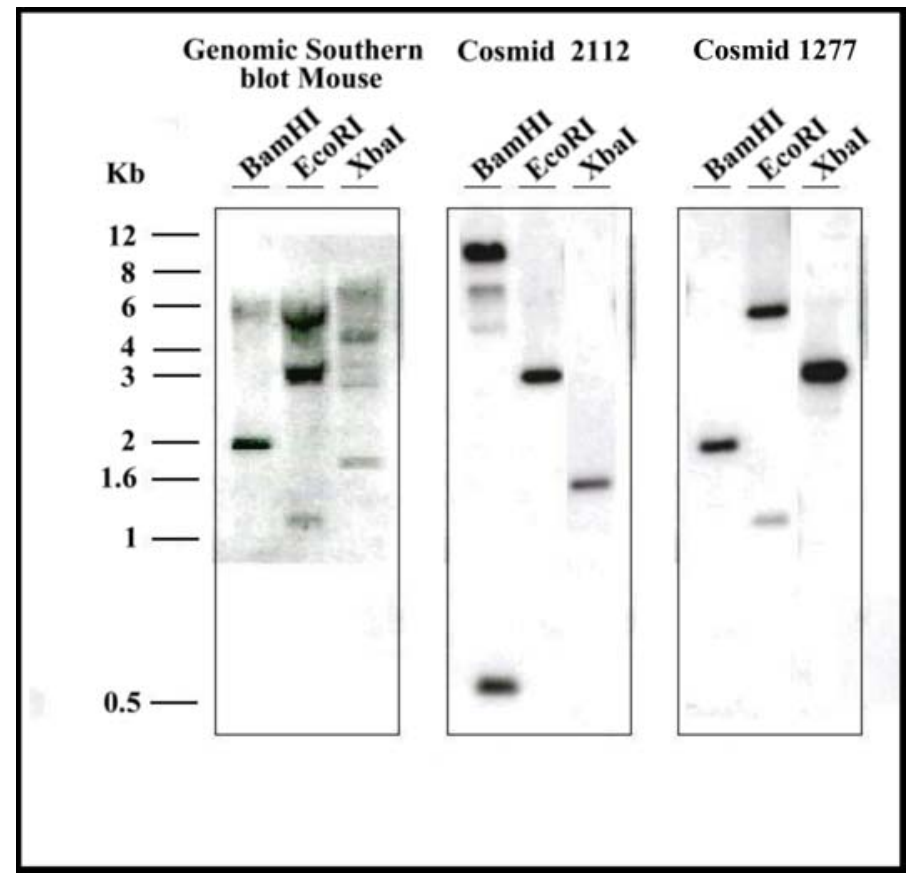

Fig. 3.36. TSEP22 Southern blot of mouse genomic and cosmid DNA.

The figure shows the films of the Southern blot with mouse genomic DNA and from cosmid 1277 and 2112 hybridised with the TSEP22 cDNA. It can be observed that the signals present in the cosmids correspond only partially to the signal pattern of the genomic Southern. Nonetheless, the pattern of both restricted cosmids taken together explains the pattern of the genomic DNA, only with two exceptions: the BamHI $6 \mathrm{~kb}$ band present in the genomic DNA cannot be found in the cosmid clones, as well as a 12 $\mathrm{kb}$ band of the cosmid clone 2112 is not present in the genomic DNA pattern. 


\subsubsection{TSEP22 Chromosomal Localisation}

The chromosomal localisation of the mouse TSEP22 gene was performed by Fluorescence In Situ Hybridisation (FISH) with help from Dr. B. Gläser (Institut für Humangenetik, Göttingen). For this purpose, the cosmid 2112 was used as a probe. Mouse TSEP22 was localized in the telomeric region of chromosome 12 (Fig. 3.37.). This region is synthenic to the human chromosome 2pter-25. When this human region was analysed in search for diseases and genes involved with reproduction or spermatogenesis, nothing was found.

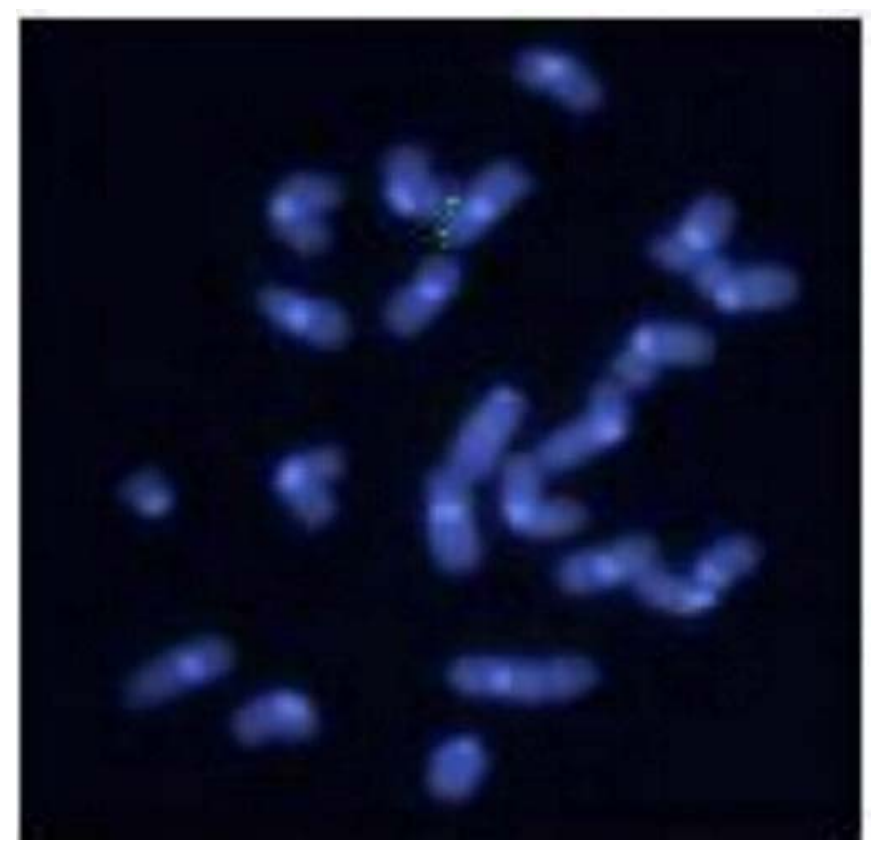

Fig. 3.37. Chromosomal localisation of the TSEP22 gene.

The picture shows the FISH hybridisation to localise the TSEP22 mouse gene using the cosmid 2112 as a probe. The TSEP22 gene was located to mouse chromosome 12 in the telomeric region. No genes involved in reproduction or spermatogenesis could be found in this region.

\subsubsection{TSEP22 Genomic Structure}

The TSEP22 genomic structure had been attempted to elucidate by subcloning the cosmid fragments resulting from a digestion with different endonucleases such as BamHI, EcoRI and PstI, into the pZERO 2.0 vector. Nonetheless, the sequencing of the genomic subclones was abandoned, because two mouse genomic clones (GI: AC073562 and AC079272) were found after a comparison in the sequence database BLAST of the NCBI (http://www.ncbi.nlm.nih.gov/BLAST/). These genomic clones contained the complete gene, for this reason, the sequencing of the pZERO genomic subclones was stopped. The mouse genomic clones published in Genbank localized to the chromosome 12pter 
(sequence in Appendix). The transcribed sequence was comprised in a genomic sequence of $16 \mathrm{~kb}$ distributed in three exons separated by two introns of 103 and 13,160 bp, respectively (Fig. 3.38.). The different cDNA sequences arise from alternative splicing of the hnRNA from the exons as well as from internal exon sequences, which presented inner acceptor-donor splicing sites. An exception is the sequence for the sequence block B, which had the sequence of the first 24 bp of TSEP22. In this case, no acceptor-donor splicing site was found. Three GC boxes that lie at the positions 21, 40 and 492 of the first exon were found and can probably be involved in the transcription regulation of the TSEP22 gene.

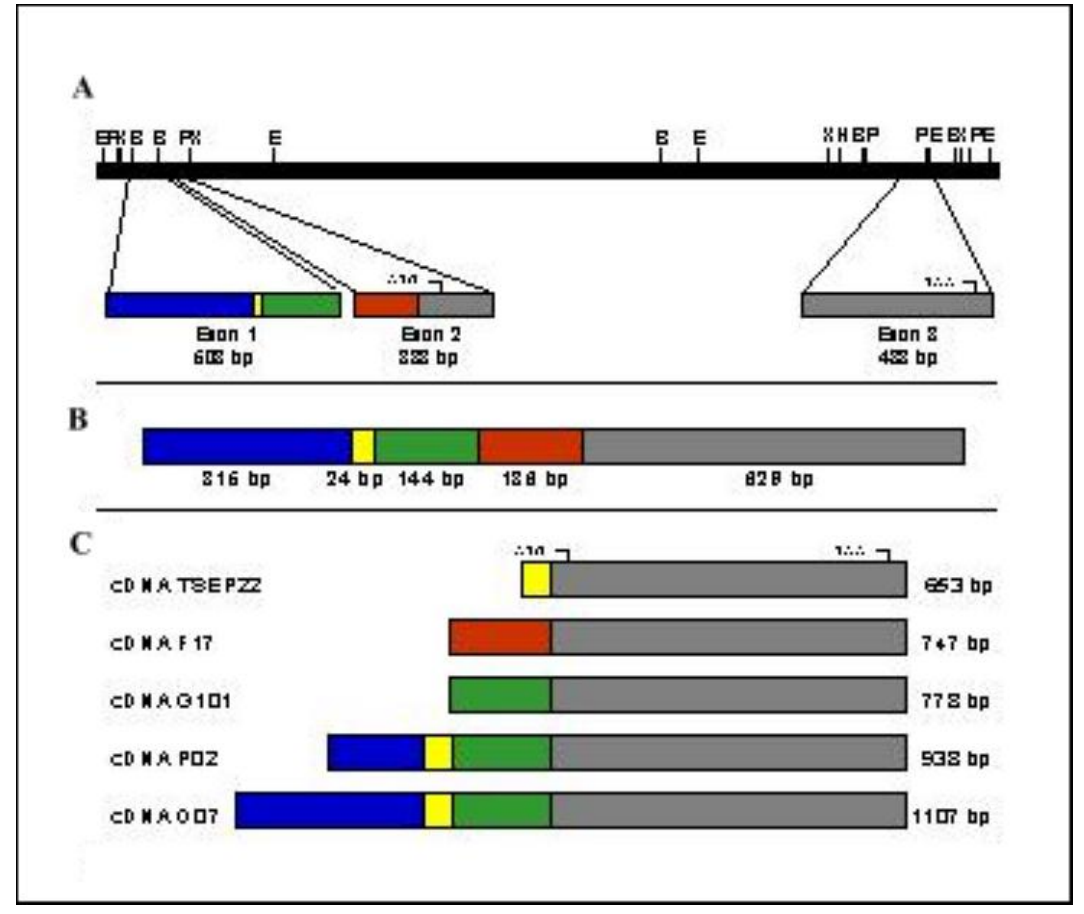

Fig. 3.38. Genomic structure of the TSEP22 gene.

The scheme A represents the genomic structure of the TSEP22 gene deduced from the cDNA sequence together with the database information. The restriction sites of BamHI (B), EcoRI (E), HindIII (H), PstI $(\mathrm{P})$ and $\mathrm{XbaI}(\mathrm{X})$ are drawn as a reference. The first intron is $103 \mathrm{bp}$ long and the second intron is 13.16 $\mathrm{kb}$. B and C: It is schematically represented how the hnRNA can originate the 5 different TSEP 22 cDNAs.

\subsection{Protein Analysis}

\subsubsection{Sequence Analysis of the TSEP22 Protein}

The putative TSEP22 protein consists of 189 AA with a molecular weight of $21.5 \mathrm{kDa}$. Using different computer protein analysis programs, only two motifs were found: a glutamine rich region from aa 5-50 and the Bipartite nuclear localisation signal from AA 60-77 (Fig. 3.39.). 


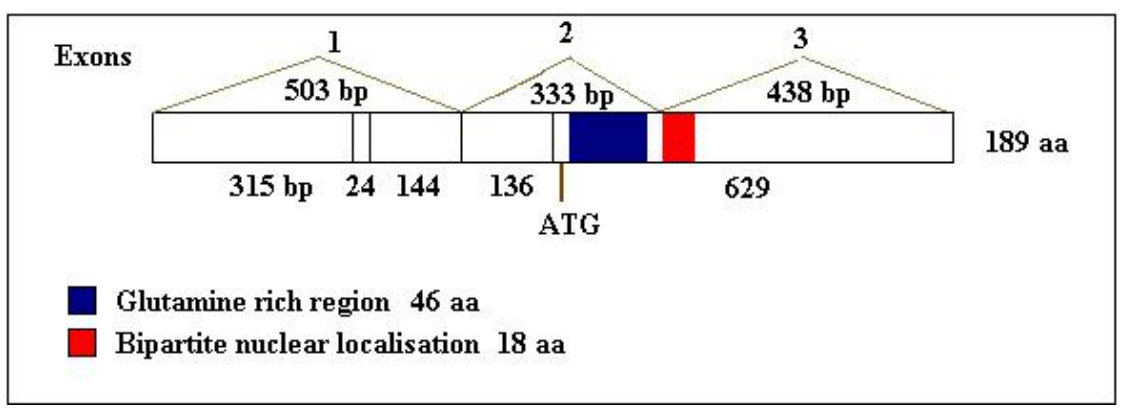

Fig. 3.39. Protein domains present in the TSEP22 protein.

The TSEP22 protein contains a glutamine rich region, up to $25 \%$ from aa 5-50. Also a high content of proline $(9.5 \%)$ was observed. The bipartite nuclear localisation signal suggests that the TSEP22 gene codes for a nuclear protein.

The glutamine rich region is not properly a protein domain and does not have any known functional effect. It refers to the high content of glutamine in the aa sequence up to $25 \%$ in the mentioned lapse (aa 5-50), which is very high comparing to the expected $4.02 \%$ average frequency. Also a high content of proline $(9.5 \%)$ was observed. The Bipartite nuclear localisation signal suggests that the TSEP22 gene codes for a nuclear protein. This is corroborated by the "Reinhardt's method of cytoplasmic/nuclear discrimination", which predicts a $94.1 \%$ probability of a nuclear function. Also, a putative N-glycosylation site was found (aa 67-70), five putative phosphorylation sites (aa 35-38, 69-72, 87-89, 124-127 and 183-185) and two putative myristylation sites (aa 29-34 and 63-68).

Several attributes can be deduced from the amino acid sequence. For example, the secondary structure is helical after the model of Robson. The $\mathrm{pI}$ of the TSEP22 protein is 4.77 , proving to be an acidic protein. The putative TSEP22 protein can be catalogued as a hydrophilic protein and does not contain any transmembrane domain.

\subsubsection{Generation of a TSEP22-Strep-tag Fusion Protein}

A fusion protein was produced in order to isolate a pure monospecific antibody against TSEP22 and continue the expression analysis of TSEP22. This fusion protein was obtained by cloning a PCR product (generated with the primers FP-For and FP-Rev) into the vector pASK-IBA II (IBA, Goettingen), using BsaI restriction sites. The resulting clones were cultured, purified and tested for the presence of the fusion protein by Western blot (Fig. 3.40.). After this, the clone with the best protein expression was chosen to purify the 
antibody present in the antiserum of two previously immunized New Zealand rabbits. The purified antibody obtained ( $\alpha$-TSEP22), was used for immunohistochemical studies.

\subsubsection{TSEP22 Western Blot}

In order to demonstrate the TSEP22 protein distribution in different tissues, Western blot analysis with proteins from different adult mouse tissues was done. A band $\sim 22 \mathrm{kDa}$ could be observed only in testis (Fig, 3.40. A), finding that corroborates the Northern blot results. Besides, through the Western blot analysis of the TSEP22 gene, it was possible to detect the exact time when the translation of this gene begins. A Western blot was prepared with proteins extracted from different testicular development stages. This blot was incubated with the $\alpha$-TSEP22 antibody followed by an anti-rabbit antibody coupled with alkaline phosphatase. In the Western blot membrane, a band of $22 \mathrm{kDa}$ could be detected in the testicular samples from postnatal day 18 (Fig. 3.40. B). The TSEP22 transcripts are detected in testis RNA from postnatal day 15 and the TSEP22 protein is expressed first from postnatal day 19. $\alpha$-tubulin was used to check the quality and concentration of the protein extracts.

\subsubsection{Immunohistochemical Analysis of TSEP22 in Testis Sections}

The TSEP22 transcript was localised in testis sections in the range from primary spermatocytes to spermatids (in situ hybridisation, 3.6.2.2). Therefore, it was interesting to analyse the point when the TSEP22 protein appears in testis. For this, an immunohistochemical analysis of TSEP22 in paraffin testis sections from adult mouse (4-5 $\mu \mathrm{m}$ width) was performed. Mouse testis sections were incubated with purified monospecific $\alpha$-TSEP22 antibodies. The testis preparations were incubated with the antirabbit IgG coupled with alkaline phosphatase as second antibody. Also, control slides were incubated only with the second antibody. 


\section{Results}

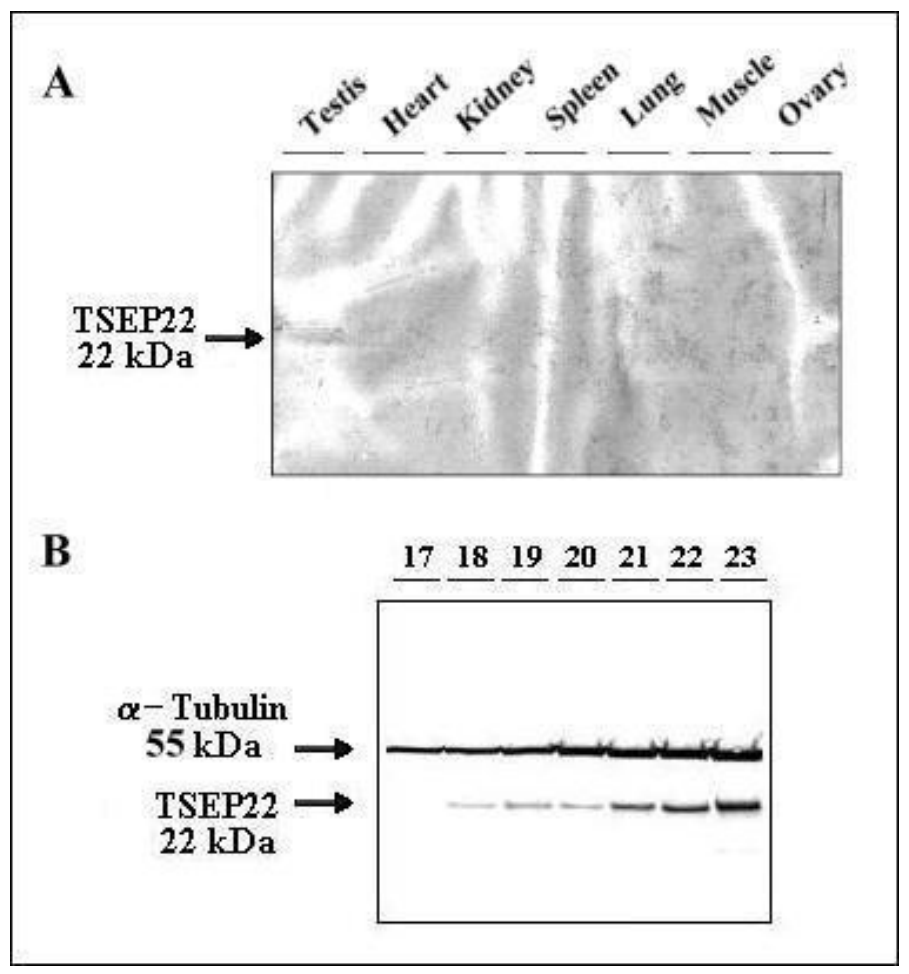

Fig. 3.40. Western blot with protein extracts from different testicular developing stages.

The western blots show the detection of the TSEP22 protein with rabbit $\alpha$-TSEP22 antibodies in different tissues (A) and testicular protein during development stages (B). A: the TSEP22 was observed only in testis. B: the TSEP22 protein could be detected from day 18. In this membrane, the $\alpha$-tubulin was used to check the concentration of the protein extracts.

A weak positive signal of $\alpha$-TSEP22 could be observed first from primary spermatocytes. The signal became stronger with the increasing developing testis stages from spermatocytes until spermatids (Fig. 3.41.). The probes incubated with the negative control, showed no signals.

\subsubsection{Immunocytochemical Analysis of TSEP22 in Mouse Spermatozoa}

After the observation of the TSEP22 transcript in primary spermatocytes and spermatids (3.6.2.2.) and the TSEP22 protein in the same testis cell types (3.8.3.), immunocytochemical analysis of the distribution of the TSEP22 protein in mouse spermatozoa was done. To accomplish this, spermatozoa from adult mouse were incubated with purified monospecific $\alpha$-TSEP22 antibodies. The procedure practiced with mouse spermatozoa was identically performed as with the paraffin testis sections (3.8.3.). 

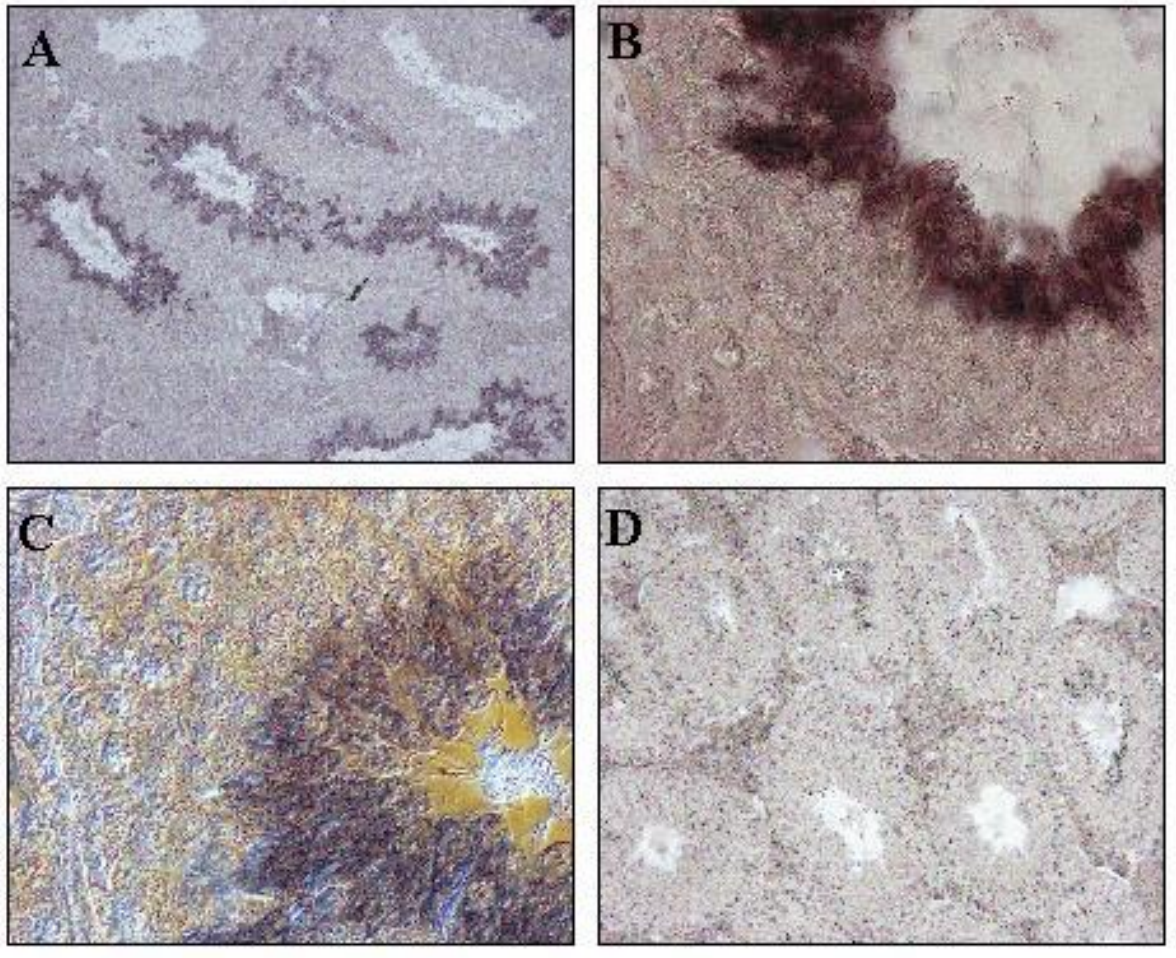

Fig. 3.41. Immunohistochemical analysis of TSEP22 in testis sections.

The figure shows sections with adult mouse testis incubated with $\alpha$-TSEP22 polyclonal antibodies and stained after incubation with anti-rabbit IgG conjugated with alkaline phosphatase (A-C). The positive staining is seen as a dark purple signal. Preparations showed that the antibodies recognize the protein weakly in primary spermatocytes and more intensively in spermatids. According to the intensity of the signal, it seems that the expression of the TSEP22 gene increases as the spermatid differentiation advances. It is remarkable the intensity of the signal in late spermatids.

After this procedure, a positive red signal could be detected in midpiece of the spermatozoa tail (Fig 3.42.). According to this, the expression of the TSEP22 gene in sperm is restricted to the midpiece of the tail.

\subsubsection{Generation of a TSEP22-GFP Fusion Protein}

The previous experiments with the specific TSEP22 antibody could date the occurrence of the TSEP22 protein, but were not able to situate its localisation to cytoplasma or nucleus. In order to determine the sub-cellular localisation of the TSEP22 protein, a TSEP22 fusion protein with the green fluorescent protein (GFP) was generated. 


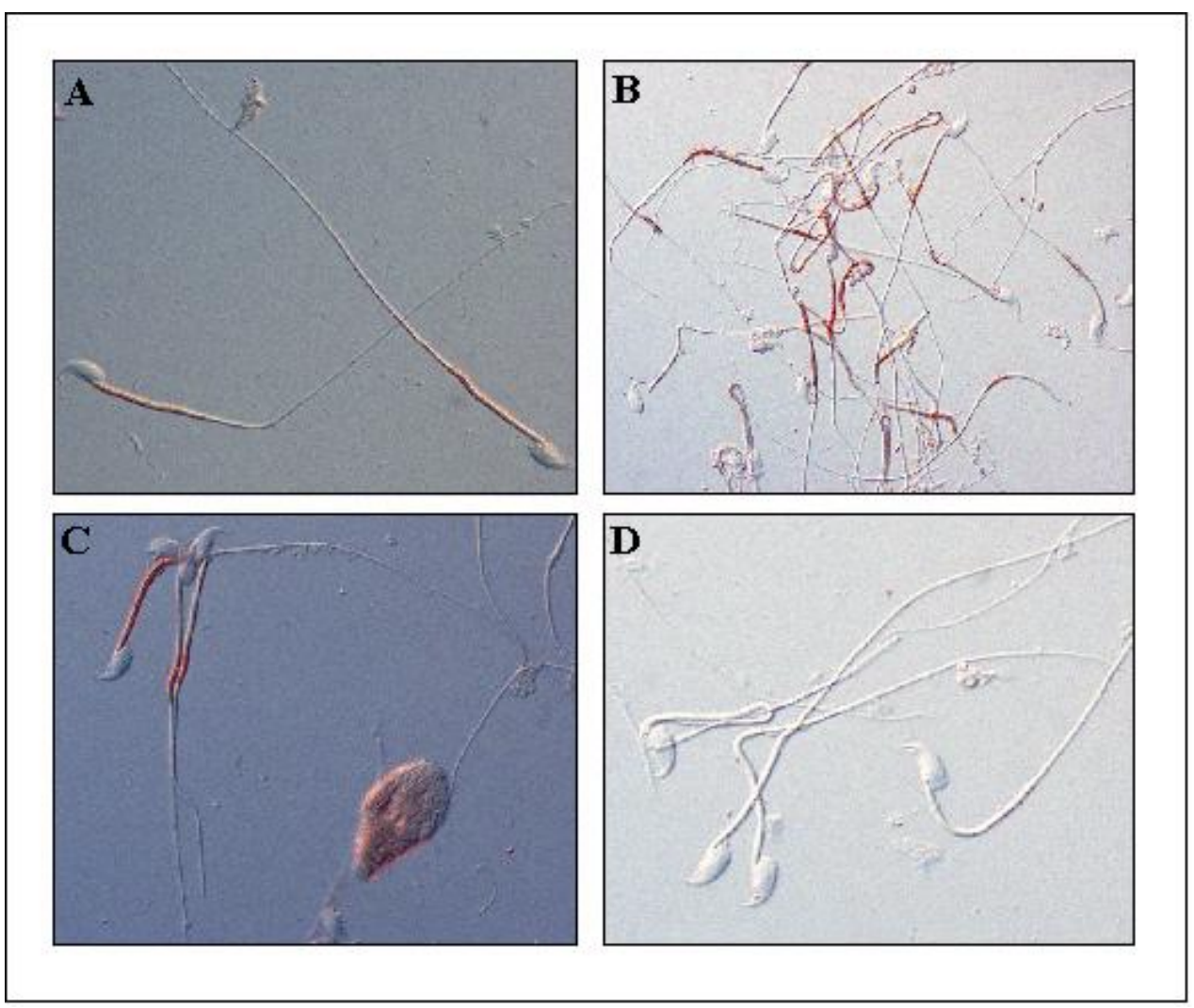

Fig. 3.42. Immunohistochemical analysis of TSEP22 in mouse spermatozoa.

1A-B and 2A-B show mouse spermatozoa incubated with $\alpha$-TSEP22 antibodies and with alkaline phosphatase conjugated anti-rabbit antibodies as second antibody (A-C). As a control, spermatozoa were incubated only with the second antibody (D). There was a clear purple signal in the sperm midpiece with anti-TSEP22 antibodies that contrasted with the absence of signal in the preparations incubated only with the second antibody.

The TSEP22 entire coding region was cloned in the pEGFP-C1 vector (Clontech) at the $\mathrm{C}$ terminus of the GFP using the BamHI and HindIII restriction sites generated by the primers Gfp-For and Gfp-Rev. The resulting TSEP22-GFP clone was tested by sequencing and afterwards used for transfection in the cell lines 15P1 and 3T3 (Leydig and fibroblast cells, respectively. As a transfection control, the cell lines mentioned were transfected with the vector alone. At $500 \mathrm{~nm}$, green fluorescent signals could be observed in the transfected cells. The green fluorescent signal was observed clearly in the cytoplasma region, but not in nucleus (Fig. 3.43.). By overlapping with the DAPI detection, this can be corroborated. This finding suggests that the TSEP22 gene appears to encode a cytoplasmic protein that does not interact with the nucleus. 


\section{Results}
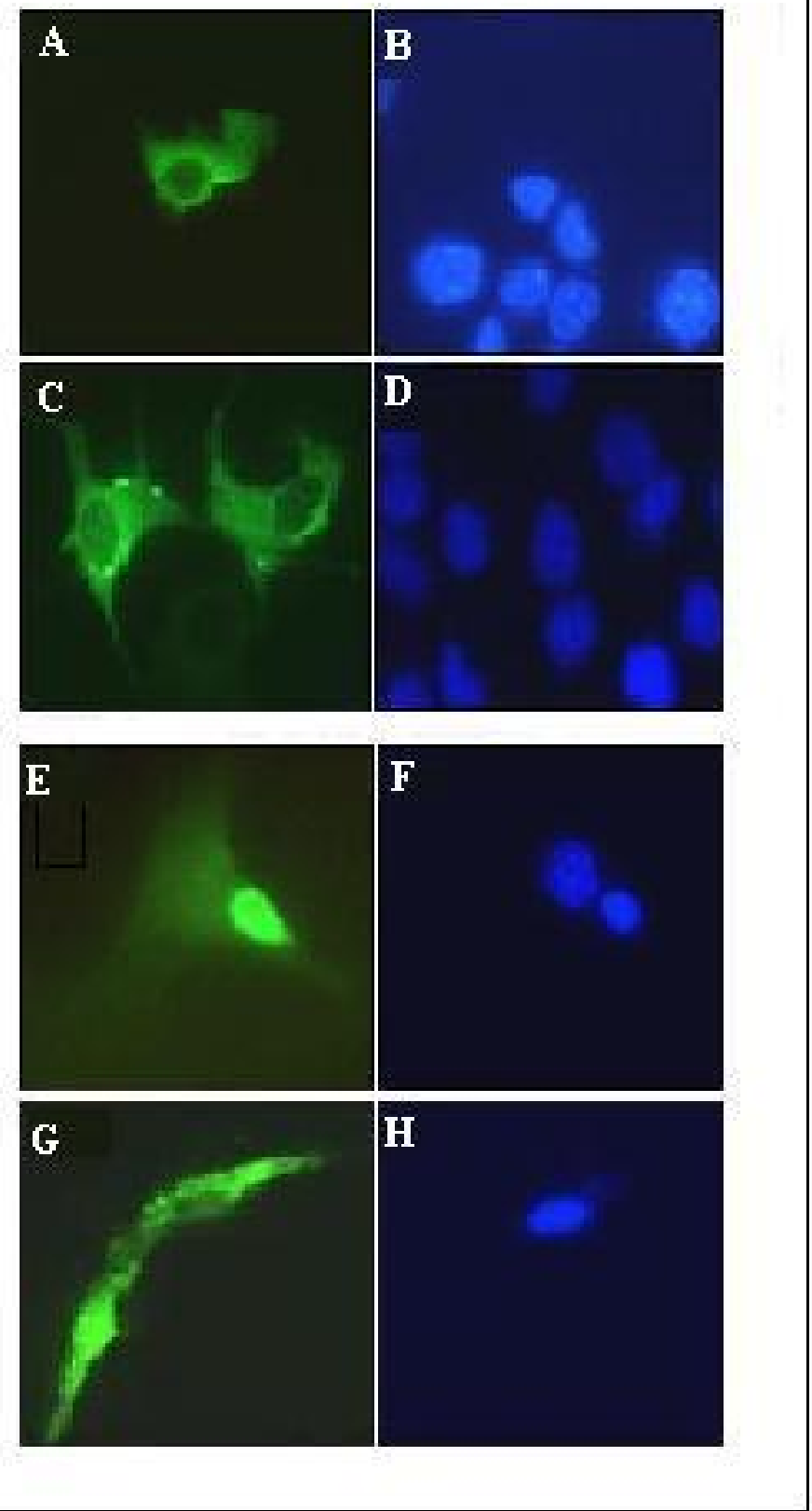

Fig. 3.43. Subcellular localisation of the TSEP22-GFP fusion protein.

Analysis of the in vitro localisation of the TSEP22-GFP fusion protein in 15PI cells (1A) and 3T3 cells $(2 \mathrm{~A})$, as well as the control expression of the GFP vector alone in both types of cells $(1 \mathrm{C}$ and $2 \mathrm{C}$, respectively). All 4 different preparations were stained with DAPI to evidence nuclei. It can be observed that the TSEP22-GFP fusion protein is only present in the cell cytoplasma in both cell lines. The control GFP vector shows a distinctive pattern brighter than that obtained with the fusion protein and also predominantly in cytoplasma. 


\section{DISCUSSION}

Several different cDNA clones with very weak similarity to other mouse sequences previously reported in the database (BLAST, NCBI) were isolated from a mouse testes cDNA phage library with an $8 \mathrm{kDa}$ light chain (dlc1) partial cDNA as a probe under low stringency conditions. From these clones, two (25 and 36) were characterized in this work. They were chosen for further analysis due to their strong expression in testicular haploid germ cells, as long as we are interested in research genes relevant for reproduction.

\subsection{Hook1 Gene}

\subsubsection{The Murine Hook1 is a Member of the Hook Gene Family}

When the nucleotide and amino acid sequence of the mouse cDNA clone 25 were analysed in the Genbank database, strong similarities with nucleotide and amino acid sequences of the human Hook1 gene were found ( $85 \%$ and $92 \%$, respectively). For this reason, the clone 25 was named mouse Hook1. The isolated clone comprised $1806 \mathrm{bp}$ and presented the cDNA polyA tail in the 3 '-end together with the atypical polyadenylation signal AAGAAA. Polyadenylation is the process of 3 '-end formation in eukaryotic mRNAs, which is required for synthesis, transport, translation and stability of most mRNAs (Wilusz and Shenk, 1988). The typical sequence AAUAAA specifies accurate and efficient addition of poly(A) to the mRNA 3'-end (Proudfoot and Brownlee, 1976; Fitzgerald and Shenk, 1981). Substitutions at any position in this sequence diminish polyadenylation in vivo and in vitro (Hara et al., 1992) and 90-95\% of sequenced mRNAs have AAUAAA in their 3'-ends (Colgan and Manley, 1997; Manley, 1995). However, many mRNAs expressed in male germ cells do not have AAUAAA (Øyen et al., 1990; Ravnik and Wolgemuth, 1996; Edwalds-Gilbert et al., 1997), but are nevertheless efficiently polyadenylated. In the case of the polyadenylation signal AAGAAA, it has been also observed in a mouse mRNA for zinc finger protein expressed in germ cells and embryonic nervous system (Noce et al., 1993).

The complete Hook1 cDNA sequence comprises $2478 \mathrm{bp}$, plus the polyA tail and had similarity of $92 \%$ at the nucleotide level to the human Hook1 cDNA sequence from 
nucleotide 198, but the upstream 197 bp did not show similarity to any sequence previously reported. This $197 \mathrm{bp}$ specific sequence was interpreted as being the 5'UTR of the mouse Hook1 gene. The 5'UTR has been reported in other testis-specific genes to be involved in gene regulation (Miranda-Vizuete et al., 2001).

The Hook1 gene takes its name from the Drosophila mutant that was first described by Mohr in 1927. It was recognized by its effect on bristle morphology because macrochaetes display sharply bent or truncated ends. More recently, it was observed that mutations in the Drosophila hookl gene inhibited the accumulation of the bride of sevenless transmembrane protein (boss) in multivesicular bodies (MVBs) of the R7 cells of the developing Drosophila eye imaginal disc producing strong degeneration of the ommatidia, specifically of the photoreceptor cells (Krämer and Phistry, 1996). This effect was produced because the hookl protein necessary for the endocytosis or the transport of boss into the MVBs was absent. Also, hook1 seems to be dispensable for viability, since complete all mutants were viable. This can be due to the fact that hookl inhibit the endocytosis of transmembrane ligands into MVBs, but do not completely block it. Kräamer and Phistry (1999) also isolated the Drosophila hookl cDNA, as well as the human Hook1 cDNA. Narayanan et al., (2000) reported that the hook1 Drosophila mutant increases the size of the muscle synapse. The reason is that hookl modulates endocytosis at stages required for down-regulation of membrane proteins that control synapse size by stabilizing multivesicular bodies (MVBs) in the endocytic pathway to lysosomes. These MVBs are reduced in number in the mutant hook1 and endocytosed proteins are prematurely degraded in lysosomes (Sunio et al., 1999) Also, the human proteins Hook2 and the recently isolated Hook3 (Walenta et al., 2001) are members of this Hook protein family.

Drosophila hook1 cDNA is 3290 bp long, human cDNA is 2403 bp long and mouse Hook1 cDNA is $2478 \mathrm{bp}$. At protein level hook1 is 679 AA long, whereas human and mouse Hook1 proteins have 728 aa.

\subsubsection{Expression Analysis of the Mouse Hook1 Gene}

To this concern, the Hook1 transcript is detected in a testis specific fashion by northern blot, but when RTPCR is performed, the transcript is seen in almost every tissue, with the 
exception of spleen. In this case, the RTPCR results are consistent with the fact that several EST clones in retina, brain, mammary gland, fetal liver, etc. have been found in the Genbank database. Also, the distribution of the Hook1 protein in different tissues was analysed using rabbit $\alpha$-Hook1 antibodies, which were raised against a Hook-Strep-tag fusion protein. These antibodies recognized a $\sim 84 \mathrm{kDa}$ protein in wild type testis protein extract. The tissues under analysis were: testis, eye, brain and sperm. Signals were detected in testis, eye and brain, although the bands observed in eye and brain were weaker than that obtained with testicular extract: No signal was detected in sperm. The intensity of the bands among tissues was possible to compare due to the use of antimouse $\alpha$-tubulin that generated a band of $\sim 55 \mathrm{~kb}$, and revealed a similar concentration of all tissues. All these findings let us conclude that both Hook1 transcript and protein are present in most tissues. It is remarkable the fact that both transcript and protein can be observed to be present abundantly in testis more than in any other tissue. This feature suggests that Hook1 may play an important role in testis specific processes, namely spermatogenesis.

When the Hook1 expression was analysed in testicular RNA of different developing stages, again a different expression pattern between northern blot and RTPCR was observed. The northern blot shows a detectable signal of $2.4 \mathrm{~kb}$ (that corresponds to the expected Hook1 transcript size) from day 25. However, after a longer exposition of the membrane, more signals of different lengths can be observed. From these, it is remarkable a $4.3 \mathrm{~kb}$ transcript in every testicular RNA stage tested, which started with the 10 days old testicular RNA. In the case of RTPCR, also performed with testicular RNA of developing stages, a fragment belonging to the Hook1 cDNA is obtained in all samples assayed, beginning with the 10 day old testicular RNA. On the other hand, northern blot analysis done with the testicular RNA of different mutant mouse strains revealed a signal of $2.4 \mathrm{~kb}$ corresponding to the Hook1 cDNA observed in the strains that had postmeiotic germ cells stages like olt/olt and $\mathrm{qk} / \mathrm{qk}$. In strains that have only somatic cells or premeiotic germ cells in testis, such as $\mathrm{W} / \mathrm{W}^{\mathrm{v}}$, LeyIL-/- and $\mathrm{Tfm} / \mathrm{Y}$, no Hook1 transcript could be detected. These northern results are consistent with the pattern obtained by the developing testis northern blot, but not with the findings of RTPCR. Related to this matter, the Hook1 transcript was localised clearly to round and elongated spermatids 


\section{Discussion}

when in situ hybridisation with testicular tissue was performed. This finding supports the result obtained with the northern blot with mutant mouse testes tissue. In both cases, the Hook1 transcript was detected only in post-meiotic cells. Also, the immunohistochemical analysis of testicular tissue with $\alpha$-Hook1 antibodies localised the Hook1 protein as well to round and elongated spermatids. This finding clearly supports the previous results obtained with the mutant mice northern blot and the in situ hybridisation with wild type testis sections. From here, it can be concluded that the Hook1 protein could be detected in the same testicular cell type as the Hook1 transcript. Therefore, it seems that this protein is not subjected to any post-translational control. All these results point that the Hook1 protein may play an important role in spermiogenesis since its expression is restricted to the haploid stages of the germ cell development.

Concerning the expression difference detected between the RTPCR performed with tissue and testicular RNA compared to that of northern blots, it must be considered that RTPCR is a more sensitive technique that in theory can work with a single target molecule in a sample, although the usual baseline is 10-50. For this reason, RTPCR is able to detect Hook1 transcripts that probably are low expressed, which are not detectable by northern blot.

When the presence of the Hook1 protein was assayed in mouse spermatozoa, no differences could be detected between the signals obtained in both control and Hook1 specific reactions. This finding is consistent with the western blot results obtained with sperm protein extracts, where no band corresponding to the Hook1 protein could be detected. As long as Hook1 is present in late haploid cells but is absent in mature spermatozoa, it can be considered to be involved in a specific function during mouse spermiogenesis. Some other genes expressed in spermatids and absent from mature spermatozoa have been reported before. They are involved in movement of the residual cytoplasm, function that also Hook1 may perform. Some examples are: the cystic fibrosis transmembrane conductance regulator and Iba1, an ionised calcium binding adapter molecule-1. CFTR is present in rat spermatids but absent in spermatozoa. It may interact with aquaporin concerning cytoplasmic volume reduction, which is an essential feature of spermiogenesis (Gong, 2001). Also, Ibal was detected in spermatids of adult rat testis as well as in residual bodies that are ultimately engulfed by Sertoli cells. It may be involved 


\section{Discussion}

in the final stage of spermiogenesis, probably in the elimination of the residual cytoplasm from spermatids (Iida et al., 2001).

On the protein level, the mouse Hook1 has a coiled-coil motif as analysed with the program Coils2 (Lupas et al., 1991). This motif is also present in the human and Drosophila hook1 proteins as well as in the human Hook2 and Hook3 (Walenta et al., 2001). The coiled-coil domains frequently function in the dimerization of the proteins (Chevray and Nathans, 1992). In fact, it has been demonstrated that Drosophila hook1 could form homodimers (Krämer H and Phistry M, 1996). The mouse Hook1 presents three different motifs, which are filament, spectrin repeat and two leucine zippers. The leucine zippers encoded in exons 8-9 and 10-13, facilitate dimerization just as the coiledcoil motif already discussed. The filament and spectrin repeat motifs suggest that the Hook1 protein interacts with the microtubules of the cytoskeleton. All three different motifs are conserved in both human and Drosophila hookl proteins, by the exception of the second leucine residue from the first leucine zipper, which is absent in Drosophila. This conservation of the motifs among the three species, suggests the importance that these protein motifs have for the function of the protein.

The Hook1-GFP fusion protein allowed to localise this protein to the cell cytoplasm. Some brighter regions around nucleus can be observed. Although no counter staining with suitable antibodies has been made, these points are remarkably defined and may colocalise with a specific cell organelle. A similar subcellular localisation has been done with human $\alpha$-Hook1 antibodies in Hep2 cells. Even though human Hook1 is reported to be distributed in cell cytoplasm localised to discrete unidentified subcellular structures (Walenta et al., 2001), the visible distribution of human Hook1 is sensibly different from the one obtained by mouse Hook1, lacking the characteristic brighter points around nucleus. Further experiments with organelle antibodies i.e. Golgi apparatus, should be done to elucidate the nature of these intense signals. Also, in Drosophila the hook1 protein subcellular localisation was analysed. It was expressed at all stages from embryos to adult flies. In Drosophila embryos, hookl was localised to endosomes in the cortical area. A similar cortical localisation was detected in oocytes and in the cultured Schneider SL2-sev cells, the hook1 protein was detected in a punctate pattern, interpreted as small vesicular structures (Krämer and Phistry, 1996). The subcellular localisation of 


\section{Discussion}

Drosophila and mouse Hook1 fusion proteins shows consistency with the previous mentioned involvement of hookl in the endocytic trafficking of the boss transmembrane ligand into mutivesicular bodies in the Drosophila eye imaginal disc, which are cell organelles distributed in the cell cytoplasma. It is not clear if this event is accomplished by endocytosis or by transport to MVBs.

\subsubsection{Genomic Organization of the Hook1 Gene}

Concerning the genomic organization of the mouse Hook1, the analysis of the mouse gene exon-intron boundaries obtained are the same as that of the human Hook1 gene, fact that indicates that the mouse Hook1 gene has the same organization as the human gene. Both human and mouse Hook1 genes have 22 exons, even though the human exon 22 is shorter by $75 \mathrm{bp}$. The similarity found between the human and mouse cDNA began from the ATG, though both 5'UTRs were different from each other. Remarkably, the 5'UTR from mouse Hook1 did not show any homology to sequences previously reported in the database. On the other hand, the Hook1 gene seems to be a single copy gene, due to the results obtained by comparing the hybridisation pattern from the genomic southern blot and the pattern of the mouse DNA cosmid clone, both hybridised with the Hook1 cDNA. Although one band of $\sim 5.0 \mathrm{~kb}$ and one band of $3.0 \mathrm{~kb}$ in the BamHI and EcoRI restriction, respectively, observed with the mouse genomic DNA could not be found with the cosmid clone DNA, the most bands are present in both samples. The Hook1 gene was localised to the mouse chromosome 4, region C5-D2, finding that turned out to be very significant. By analysing the mouse database in search of candidate genes in the region where the mouse Hook1 was localised, the mutation azh (abnormal spermatozoon head shape) was found. Also, other genes were found in this region like patched homolog 2 (Ptch2), mouse homolog of a receptor for one of the hedgehog Drosophila melanogaster genes. Ptch2 is expressed in ocular tissue where the hedgehog genes are expressed, suggesting that it may also be a receptor for hedgehog signals (1). It is in 4C-D. Fasassociated factor 1 (Fafl) is localised in chromosome 4C6, $52.7 \mathrm{cM}$, involved in apoptosis. The insulin-like 5 gene (Ins15) a peptide hormone is in 4C5-C7, $49.5 \mathrm{cM}$. Some mouse mutations were found in this chromosomal region, but the only one displaying a phenotype in germ cells was the mutation azh (abnormal spermatozoon head 
shape, chromosome 4C7) (Gene Expression Database, 2001). When the database was analysed looking for human disease genes in the synthenic region, namely 1p31-34, only one disease, which gene was not mapped yet was found. This disease was the muscleeye-brain disease (MEB), mapped to human chromosome 1p32-p34 (Cormand, et al., 1999). The MEB presents congenital hypotonia, mental retardation and visual failure (Raitta et al., 1978, Santavuori et al., 1989). It was interesting to consider the analysis of this disease, because it presents retinal degeneration, a feature that can be compared to the degeneration of the photoreceptor cells reported in Drosophila hookl gene (Krämer and Phistry, 1996). But as the exact localisation of the human Hook1 genomic clones was reported to be $1 \mathrm{p} 32.1$, the possibility that the Hook 1 gene could be a candidate gene for MEB was excluded because a distance of about $4 \mathrm{Mb}$ separated the MEB disease from the Hook1 gene.

\subsection{4. azh/azh Mutant Mouse}

The azh/azh mutant mouse has an important phenotype in spermatozoa. For these reasons, it was considered to be very interesting to analyse the Hook1 gene in this mutant mouse since the mouse Hook1 gene was localised to 4C5-D2 and was expressed at the level of round and elongated spermatids. The azh/azh mouse has an autosomal recessive mutation, which affects sperm morphology. This mutation was induced by radiation with 75-600 rad X-rays to the testes. All the sperm are affected, having a characteristic crescent or club shape, and up to $40 \%$ of the sperm heads may be severed from their flagella (Hugenholtz et al., 1984). The posterior part of the sperm head is not flattened as in normal sperm, but is cylindrical or conical and tapers to a relatively small diameter where the tail is attached. Tail detachment occurs more frequently than in the wild type. Unlike the wild type sperm, there is no indented region for the implantation fossa or tail attachment structure. The testes are of normal size and normal numbers of sperm are produced (Meistrich, et al., 1988). Concerning fertility, azh/azh mutant was reported at the beginning as having normal fertility or reduced to $50 \%$, comparing to the wild type counterpart (Hugenholtz et al., 1984). Later, azh/azh mice have been reported as having reduced fecundity from 5\%-10\% when compared to the wild type or heterozygous mice, whereas the fertilized ova reach in azh/azh and wild type $23 \%$ and $77 \%$ rates. The 
azh/azh mice fail to fertilize ova with intact zonae pellucidae, but are successful in fertilizing zona-free ova. The ability to penetrate the zona may be reduced by their morphological abnormalities (Meistrich, 1994). When intracytoplasmic sperm injection (ICSI) was performed injecting sperm of $\mathbf{a z h} / \mathbf{a z h}$ mutant mice into normal mouse oocytes, the club shape morphology of the $\mathbf{a z h} / \mathbf{a z h}$ sperm head was attenuated in the offspring, but a statiscally significant enhancement occurs in offspring tail abnormalities (like multifolded mid and principal tail segments, "lasso-like" tails, bending of the head together with looping of the midpiece of the developing tail) compared with the azh/azh donor (Akutsu et al., 2001). The karyotype of affected males is normal. Morphological studies have demonstrated that spermatogenesis is normal until the beginning of sperm nuclear morphogenesis (stage VIII) (Hugenholtz et al., 1984). At that point, sperm development continues, but nuclear morphogenesis occurs in a highly abnormal fashion. At spermatogenesis steps VIII-XII the abnormal positioning of the manchette microtubules was observed connected to some nuclear invaginations and evaginations. The structural appearance of the manchette is generally normal, but it has an ectopic position in the sperm. (Meistrich, et al., 1990). The nuclear abnormalities appear to be associated with or possibly caused by defects in the microtubular manchette that surrounds the nucleus (Russell, et al., 1991). Also, the manchette serves as path for the transport of organelles, i.e.: the ER that is distributed uniformly over the entire cytoplasm of spermatocytes and round spermatids moves distally toward the cytoplasmic lobe along the bundles of microtubule of the manchette, in elongating spermatids. Then, the ER is resorbed into the radial body in late maturation spermatids (Toshimori et al., 2001).

Several mutations in the mouse besides azh, including quaking (Bennett et al., 1971), several at the t-locus (Dooher and Bennett, 1974, 1977), sterile alleles at the pink-eye locus (Bryan, 1977a), hpy (Bryan, 1977b), produce abnormalities in the shape of the sperm nucleus and the overlying acrosome. Most also affect other aspects of spermatogenesis, and only azh is not pleiotropic affecting specifically sperm head shape, minimizing the chances that the nuclear abnormalities observed are secondary events. On the contrary, the likelihood of observing an abnormal subcellular structure that distorts the sperm nucleus is maximized. 


\section{Discussion}

The comparative histopathology of the homozygous mutant azh/azh and control litter mates was described in this work. The testis of the azh/azh mouse shows some abnormalities that vary from tubulus to tubulus. In $\sim 25 \%$ of the tubuli seminiferi there is an arrest of spermatogenesis at different levels, like: 1) arrest of spermatogenesis and tubuli only with Sertoli cells, 2) arrest by primary spermatocytes, 3) arrest by round spermatids and 4) arrest by elongated spermatids. The tubuli seminiferi that do not present any kind of arrest can have some defects in maturation of elongated spermatids, which include only focal spermatozoa formation and decreased efficiency in the transition from round to elongated spermatids and to spermatozoa. It is frequent the production of abnormal spermatozoa head shapes. To this respect, it was previously reported that spermatogenesis in azh/azh mice was quantitatively and qualitatively normal until the beginning of sperm nuclear morphogenesis. At that point sperm development continues, but nuclear morphogenesis occurs in a highly abnormal fashion (Russell et al., 1991). In this case, the information previously described about the testicular histopathology of $\mathbf{a z h} / \mathbf{a z h}$ is contrasting to the results obtained in this work. Maybe, this is due to a probable genetic background contamination since the mutant $\mathbf{a z h} / \mathbf{a z h}$ analysed had a genetic heterogeneity with genes from the SWR/J strain whereas the original azh/azh mutant reported and the mutant analysed in this work had a C57BL/6J(B6) background.

Also, the acrosome reaction was performed with wild type and azh/azh spermatozoa. The wild type spermatozoa had an efficiency of the acrosome reaction of $\sim 85 \%$. Concerning azh/azh mouse, two spermatozoa populations were observed: crescent-shaped and clubshaped spermatozoa. The crescent shaped spermatozoa displayed a similar acrosome reaction efficiency as that of the wild type $(85 \%)$, whereas the club-shaped spermatozoa showed a lower efficiency of $\sim 50 \%$. This lower efficiency of the acrosome reaction in the azh/azh mouse in comparison to wild type could be a factor involved in the decreased ability of the azh spermatozoa to penetrate the zona pellucida. The reduced acrosome reaction observed with the club-shaped spermatozoa feature seems to be overlooked by previous reports that describe a normal rate of acrosome reaction in the $\mathbf{a z h} / \mathbf{a z h}$ mutant mouse (Meistrich et al., 1994). Besides, in the same article, normal development of the acrosome up to the stage where head shape abnormalities appear was observed. 
Although, they speculate about the possibility that the reduced fertility observed in the $\mathbf{a z h} / \mathbf{a z h}$ mouse is due to altered enzyme levels in the acrosome of sperm.

The decrease of efficiency of acrosome reaction in the club-shaped spermatozoa seems to be ligated to its aberrant form, which is more distorted than the crescent shape, when both are compared with the wild type sperm head shape. Again differences between the data reported in the literature and the results obtained in this work could be due to the mixed genetic background that the azh/azh mutant mouse strain analysed by Meistrich had (1994), which was C57BL/6J (75\%) mixed with SWR/J (25\%).

Besides, around $55 \%$ of the spermatozoa showed a head pointing backward (as described in Akutsu et al., 2001) previously observed when the azh/azh spermatozoa was subjected to any manipulation, that contrasts with the low rate of this backward pointing spermatozoa present in fresh sperm preparations $(\sim 20 \%)$. This fragility in the connection between the head and tail together to the deformity of the head shape and low acrosome reaction of about the half of all spermatozoa might explain the low fecundity rate of 5\%$10 \%$ and the great impairment of the spermatozoa to penetrate the normal ova (Hugenholtz et al., 1984; Meistrich et al., 1994). Even when Akutsu et al. (2001) have reported the presence of backwards pointing sperm, they have not reported that this phenomenon is not present in the fresh sperm of the azh/azh mutant, but only after manipulation.

\subsubsection{Expression Analysis of the Hook1 Gene in the azh/azh Mutant}

The northern blot performed with wild type and azh/azh mutant RNA showed a difference of the bands size. The band obtained with the wild type RNA was $2.4 \mathrm{~kb}$ whereas the band observed with the $\mathbf{a z h} / \mathbf{a z h}$ RNA was of $\sim 2.0 \mathrm{~kb}$. The deletion of approx. $400 \mathrm{bp}$ found in the azh/azh mutant mouse suggests that the Hook1 is a strong candidate gene for being responsible of the mutant phenotype in the azh/azh mutant mouse.

The RTPCR revealed that one of the three fragments used to amplify the complete Hook1 cDNA sequence showed a difference in size of $\sim 400$ bp between the wild type and the azh/azh mutant. When this fragment was sequenced, a deletion comprising the whole exons 10 and 11 was observed. The heterozygote presents both sets of bands. This 
RTPCR result supports the finding of the northern blot. The frame shift produced by this deletion of exons 10 and 11 could result in a truncated amino acid sequence of 281 aa, due to the early appearance of a stop codon. By this way, two motifs of the protein are lost, namely the second leucine zipper and the spectrin repeat motifs. As discussed before, these motifs are reported to facilitate dimerization and interact with the microtubules of the cytoskeleton, respectively. The loss of function of these motifs can maybe explain how modifications present in Hook1 gene are able to originate the aberrant phenotype observed in azh sperm.

Two of the three RTPCR fragments assayed to amplify the complete Hook1 cDNA presented two bands each, one with the expected size according to the cDNA sequence and another $\sim 100 \mathrm{bp}$ smaller. The smaller fragments in all samples suggest that an alternative splicing form of the transcript is present in testis. This matter remains to be analysed in the future.

The western blot analysis of testicular protein extract from azh/azh mutant using rabbit $\alpha$-Hook1 antibodies revealed the absence of the expected band of $\sim 84 \mathrm{kDa}$ that was detected in the wild type mouse. The control band of $\alpha$-tubulin confirms the quantity and quality of the $\mathbf{a z h} / \mathbf{a z h}$ testis protein. This finding occurred because the $\alpha$-Hook1 antibodies were generated with a Hook1-Strep-tag fusion protein containing the cDNA region from base 1638-2184 (exons 15-22), which corresponds to the residues 480-662. As mentioned before, at the cDNA level, a deletion of the exons 10 and 11 that produced a frame shift was found. This frame shift could result in a truncated protein with 281 residues instead of the 728 present in the native Hook1. For this reason, the $\alpha$-Hook1 antibodies could not detect the truncated Hook1 protein present in the $\mathbf{a z h} / \mathbf{a z h}$ mutant.

\subsubsection{Genomic Analysis of the Hook1 Gene in the azh/azh Mutant}

On the basis of the deletion in the Hook1 cDNA detected by RTPCR, a genomic fragment spanning exons 9-12 was amplified with wild type, heterozygote $(+/ \mathbf{a z h})$ and homozygote azh/azh DNA. In this case, a deletion in the azh/azh mutant was observed when the PCR fragments were compared to those of wild type mouse. The heterozygote DNA presented both bands. 
Several research groups have worked with the $\mathbf{a z h} / \mathbf{a z h}$ mutant because of its unique feature of displaying an abnormal phenotype that affects exclusively the spermatozoa head shape, quality that makes this mutant mouse the subject in reproduction investigations concerning the study of head shape alterations. The general method used until now to identify the homozygous azh/azh from the heterozygous or wild type litter mates is through testicular biopsy, but it is clear that such procedure is not totally effective. In fact, for this research, an acquired heterozygous $+/ \mathbf{a z h}$ mouse resulted to be a wild type mouse, confirmed by the genomic PCR together with the analysis of the generated offspring. Now, we propose that a deletion of the Hook1 gene can be responsible for the mutant phenotype azh/azh. Therefore, by simple PCR, it might be possible to genotype the mice coming from a litter with the azh allele background effectively and rapidly. Until now, 59 mice coming from five breeding crosses have been amplified with a relation of genotype-phenotype of $100 \%$, using only a small piece of tail. By this way, it was clearly demonstrated that both heterozygous and homozygous mice presented the deletion, and that the deletion segregated with the phenotype. Interestingly, Meistrich et al. (1994) speculated that the azh mutation should arise from a deletion at a regulatory locus. Besides, they believe it is possible that the more cylindrical, less flattened spermatozoa heads, the most of which lack the pointed hook, can be some causes of the reduced fertility, since they would be unable to concentrate penetrating forces in as small an area as wild type sperm do. This sperm form defect together with the possibility that altered enzyme levels in the acrosome of sperm suggest that in the low fecundity observed in the azh/azh mouse can be due to inability to fertilize ova. These hypotheses could be right, but certainly the disassembly easiness displayed by the sperm head and tail as well as the reduced acrosome reaction seen by club-shaped sperm in $\mathbf{a z h} / \mathbf{a z h}$, can probably also play a role in the reduced fertility observed in the azh mutation. Concerning this matter, some unexplained human infertility cases have been reported to be related to the fragility in the connection between head and tail and with abnormal spermatozoa head shape (megalohead and pinhead) (Kahraman et al., 1999; Kamal et al., 1999). It would be interesting to analyse DNA of these patients to look for possible mutations in the human Hook1 gene. 


\section{Discussion}

By analysing the nature of the defect present in the azh/azh mouse, it has been observed that in longitudinal sections of developing spermatids tails of $\mathbf{a z h} / \mathbf{a z h}$, the midpiece revealed a structurally intact axoneme surrounded by dislodged mitochondria at a focal point where the abnormal accumulation of dense material was observed (Mochida et al., 1999). This accumulation is not present in wild type spermatids. This finding strongly suggest that there could be a blockage in the transport of some material in the mitochondrial sheath during the spermatid stage related to the azh/azh mutation, since this accumulation is not present in wild type and heterozygous mice. What is more, some dense material (named linkers) have been reported to be between the nuclear envelope and the manchette, attaching individual microtubules of the manchette to one another as well as microtubules of the nuclear envelope. These rod-like linkers were not seen in spermatids after elongation occurred and the manchette has been displaced caudally. They may have the task of maintaining parallel the manchette with respect to the nuclear envelope and helping the manchette to "zipper" down the nuclear envelope, thereby changing its shape. These linkers may be microtubule-associated proteins (MAPs) or microtubule motor proteins (cytoplasmic dyneins or kinesin) that bind microtubules and stabilize and link them to each other. Nothing is cleared about the linkers in the azh/azh mutant (Russell et al., 1991). According to Walenta et al. (2001), a function of Hook proteins as microtubule linker proteins is also consistent with the analysis of Drosophila hook1 loss-of-function mutations in endocytic trafficking. Drosophila hookl appears to be responsible for the assembly or stability of mature MVBs (Walenta et al., 2001) and probably be microtubule linkers necessary for the anchoring of organelles in their characteristic positions (Nielsen, et al., 2000). Concerning this, it is noticeable to keep in mind that the manchette serves as a path for movement of organelles during the spermiation.

Mochida et al. (1999) speculated that the sperm tail abnormalities such as bending and looping of the midpiece of the tail of azh spermatozoa could reflect structural and/or assembly deficiencies of peri-axonemal proteins responsible for maintaining a stiffened tail during spermiogenesis and sperm maturation (1999). These probable deficiencies in assembly of peri-axonemal proteins could be related to the dysfunction of the Hook1 protein, which is truncated in the azh/azh mouse due to a deletion of the exons 10 and 11. 
On the other hand, Hook1 could also be a microtubule-dependent motor protein that provides a solid framework for transport of organelles along microtubules. Concerning this, accumulation of dense material was observed in the flagella of Chlamydomonas fla14 mutant homolog to the $8 \mathrm{kDa}$ dynein light chain (Pazour et al., 1998) similarly as dense material was seen to accumulate in the principal piece of the azh mutant spermatozoa. In fact, it has been speculated that vesicular transport between compartments is organized along microtubules: trafficking from early to late endosomes depends on microtubules, as does retrograde and anterograde trafficking between the Golgi complex and the ER (Gruenberg and Howell, 1989, Lippincott-Schwartz, 1998). Concerning this, the actin cytoskeleton plays an active role in the engulfment of phagocytosed material (Allen and Aderem, 1995). An intriguing connection between the function of Drosophila hookl and actin cytoskeleton is provided by the visible bristle phenotype of hookl mutations. Mutations in the forked, chickadee and singed genes cause malformations of bristles similar to hook mutations. The chickadee and singed genes encode Drosophila homologues of the actin-binding proteins profilin and fascin. Profilin is a family of actin-binding proteins. It is involved in diverse functions such as maintaining cell structure integrity, cell motility, tumor cell metastasis, as well as growth factor signal transduction. Some members of this family are ubiquitous, but there is one form specific for kidney and testis. Fascin is expressed in several tissues including eye, brain, uterus, and in Drosophila the female mutants are sterile. These proteins are required for the formation of actin bundles in the early stages of extension of the bristle shaft, but the function of these actin-binding proteins is not restricted to the formation of bristles (Cant et al., 1994). To date the role of these proteins in phagocytosis or endocytosis of transmembrane ligands has not been tested.

In this work, the mouse Hook1 gene was characterized and it was demonstrated the importance of this gene in spermatogenesis and that loss of Hook1 function results in an azh/azh mutant phenotype. Also, from the findings found in this work, it can be speculated that mutations of the human Hook1 gene can be responsible for a genetically cause of male infertility in humans. 


\subsection{TSEP22 Gene}

\subsubsection{TSEP22 constitutes a Novel Testis-Specific Gene}

The clone 36 was also isolated by screening a mouse testes cDNA phage library with an 8 $\mathrm{kDa}$ light chain (dlc1) partial cDNA as a probe under low stringency conditions. This clone comprised 657 bp long including a 63 bp 5'UTR and a 27 bp 3 'UTR. No complete Kozak's consensus sequence was found around the initial ATG, [CCA/GCC(ATG)G], but only a guanine after the ATG codon (Kozak, 1987). The open reading frame (ORF) coded for a 189 aa protein. The sequence AATTTT $36 \mathrm{bp}$ upstream from the stop codon can be a possible atypical polyadenylation signal. As discussed before with the Hook1 gene polyadenylation signal, many mRNAs expressed in male germ cells do not have the typical polyadenylation signal AAUAAA (Øyen et al., 1990; Ravnik and Wolgemuth, 1996; Edwalds-Gilbert et al., 1997), but signals with modification that nevertheless can efficiently polyadenylate the sequences. The functional significance of these unconventional polyadenylation signals in male germ cells is not clear. Many mRNAs are expressed in multiple tissues, but the testicular message uses a different polyadenylation site. Even when the polyadenylation mechanism overlooks a canonical AAUAAA polyadenylation signal for a germ cell-specific site, yet these mRNAs have normal poly(A) tails. One hypothesis to account for the use of non-AAUAAA signals is that a protein involved in polyadenylation is altered in germ cells (Wallace et al., 1999).

\subsubsection{Expression Analysis of the TSEP22 Gene}

Northern blot analyses were performed with RNA from brain, heart, lung, spleen, liver, muscle, kidney, ovary, uterus, epididymis and testis, and three different transcripts of 0.8 , 1.0 and $1.4 \mathrm{~kb}$ were detected only in a testis-specific fashion. The RNA quantity and integrity were checked by hybridising with the human elongation factor (hEF) cDNA. Due to the unexpected detection of three transcripts longer than the TSEP22 cDNA, RNA was handled with RNase $\mathrm{H}$ to exclude that the bigger transcripts were due to variations in the polyadenylation. Even after the RNase treatment, at least three different transcripts 200 bp shorter than that present in the control RNA could still be detected. 


\section{Discussion}

As long as the TSEP22 cDNA was too short (657 bp) to correspond to the size of the different transcripts obtained, it was necessary to search for additional longer cDNA clones. The isolation of new TSEP22 cDNA clones was done by screening a RZPD mouse testes cDNA library. On the basis of their restriction patterns and size, four cDNA clones were chosen for sequencing. Some sequence regions similar among the different clones were grouped as blocks, namely: $\mathrm{A}_{1}, \mathrm{~A}_{2}, \mathrm{~B}, \mathrm{C} . \mathrm{D}$ and $\mathrm{E}$, being $\mathrm{A}_{2}$ the most proximal sequence; and the sequence $\mathrm{E}$ the most terminal in the cDNA. The length of these clones was compatible to that of the different transcripts obtained by the RNase $\mathrm{H}$ experiments. Concerning this, some other testis-specific genes have been reported to have several transcripts due to alternative transcription initiation sites, such as the mouse somatic cytochrome $\mathrm{c}$ that presents 4 transcripts in spermatogenic stem cells through early meiosis (Hake and Hecht, 1993). The differential regulation of somatic and testisspecific cytochromes c during spermatogenesis in the mouse is accompanied by changes in mRNA length. Also, the presence of multiple transcripts due to cryptic splice sites, exon skipping, insertion of intronic sequences, and exon scrambling was found in the human PISSLRE gene, which is a candidate tumor suppressor gene, which codes for a putative cyclin-dependent kinase (Crawford et al., 1999). The human aminobutyric acidtype A receptor 5 subunit gene (GABRA5) is widely expressed in brain and localized to the imprinted human chromosome 15q11-q13. It presents three distinct mRNA isoforms, each of which differs only in the noncoding 5' UTR sequence. The mRNA isoforms resulted from three alternative first exons (Kim et al., 1997). In the case of TSEP22, careful genomic sequence analysis should be performed to try to elucidate the mechanism by which the different TSEP22 transcripts are generated.

The testis specific nature of the transcripts detected with the TSEP22 cDNA led to the analysis of mRNA from different mutant mice with defects in different stages of spermatogenesis. In this case, strong signals could be detected in strains containing postmeiotic germ cell stages such as olt/olt and qk/qk (arrest in early spermatids and elongated spermatids respectively), as well as weak signals in the strains that present only premeiotical germ cells ( $\mathrm{Tfm} / \mathrm{Y}$ and Ley-IL-/-, arrest in primary spermatocytes). No transcripts were observed in mutants presenting only somatic cells and no germ cells $\left(\mathrm{W} / \mathrm{W}^{\mathrm{v}}\right)$. This feature was reinforced by the result obtained with the in situ hybridisation 
with testicular tissue, where the TSEP22 transcripts were detected in primary spermatocytes and elongated spermatids. Also consistent with the previous findings is the result of the northern blot analysis with mRNA from developing postnatal testes, performed using the TSEP22 cDNA as a probe. All three transcripts detected previously in testis RNA could be detected in testicular RNA from postnatal day 15. This feature indicates that the expression of the gene starts in pachytene primary spermatocytes.

When testicular tissue was assayed with $\alpha$-TSEP22 antibodies to know the distribution of the TSEP22 protein, a weak positive signal of $\alpha$-TSEP22 could be observed in primary spermatocytes, but the positive signal became stronger as the testicular cells advanced in development, being found higher expression in round spermatids while the strongest staining is observed in elongated spermatids.

Together, these results strongly suggest that the TSEP22 gene is subjected to posttranscriptional control. It can be speculated, that the different 5'UTRs of the TSEP22 transcripts are involved in the process of post-transcriptional control. In this context, there are some genes with a similar pattern, in which the 5'UTR plays a role in the regulation of the retarded translation like the acrosin gene. The proacrosin gene is transcribed in diploid spermatogenic cells and translated in haploid round spermatids. For this gene, some testis specific nuclear factors were found to interact with three testis specific binding sites (F1, F7, TS2), located in the 5 'flanking region of the rat gene (Kremling et al., 1995). There are some other cases of post-transcriptional regulation similar to that displayed by the TSEP22. For example, the vascular endothelial growth factor (VEGF) gene that is involved in tumor angiogenesis, presents a multi-level regulation at the transcriptional and post-transcriptional levels to ensure proper expression during embryogenesis and adulthood. Its mRNA contains an exceptionally long (1038 bp) 5' untranslated region (5'UTR), which has a role in transcriptional as well as translational regulation of VEGF expression. It has an open reading frame (ORF) in the 5'UTR that encodes for new putative isoforms of VEGF due to alternative translational initiation from CUG codons. These isoforms either possess new capabilities, which are different from the activity of the classical VEGF isoforms, or affect the efficiency and capacity of translational initiation from the canonical AUG codon (Meiron et al., 2001). 
By analysing the localisation of the TSEP22 protein in the spermatozoa, the immunocytochemical analysis performed with rabbit $\alpha$-TSEP22 antibodies revealed a positive red signal in the midpiece of the sperm tail. Along the sperm midpiece there are nine coarse outer dense fibers (ODFs), one per axonemal doublet. Each is composed mainly of keratin surrounding the axoneme. The ODFs decrease in diameter from the proximal to the distal extremity of the midpiece. These dense fibers are noncontractile and absence of outer dense fibers alters flagellar flexibility resulting in modified flagellar beat, causing sterility (Fawcett, 1970).

Also, the mitochondria are localised in the sperm midpiece. The mitochondria are responsible for supplying spermatozoa the ATP needed to their high consumption task of reaching the ova and fertilize it. In rat, each spermatozoon midpiece contains approximately 75 mitochondria. Condensed mitochondria are arranged along the cytoskeletal components of the tail, disposed tip to tip helically along the midpiece (Fawcett, 1975; Phillips, 1977). During the acrosome phase, as the cytoplasm extends along the axoneme, the mitochondria do not change much in structure, but their number increases considerably.

When the amino acid sequence of TSEP22 was analysed, a glutamine rich region was found. The Q domain of GAF (Drosophila GAGA factor) has the potential to mediate protein-protein interactions GAF binds specifically to the sequence GAGAG, and synergises with nucleosome remodelling factor to remodel chromatin in vitro. Also, the glutamine-rich domains of SP1 have been shown to be critical for transcriptional activation and multimerization, and necessary for both species-specific interactions with TBP and heteromultimerization with Octl (Aginian et al., 1999). The products of the Groucho-related gene (grg) family can also dimerize through their amino-terminal Q domains. Also, glutamine repeats themselves have been shown to mediate stable multimerization in vitro, with X-ray diffraction and molecular modelling studies suggesting they form polar zippers of antiparallel-strands linked by hydrogen bonds between amide groups (Pinto and Lobe, 1996). In GAGA factor (GAF), which is an essential gene in Drosophila that has been implicated in the maintenance of chromatin structure in transcriptionally active loci, the $\mathrm{Q}$ domain and/or flanking regions may have some functions in protein-protein interaction and multimerization as well as in the 
formation of fibres in vitro, which may be classified as amyloid fibres. (Agianian et al., 1999).

Also, in the TSEP22 amino acid sequence, a putative N-glycosylation site (aa 67-70), five putative phosphorylation sites (aa 35-38, 69-72, 87-89, 124-127 and 183-185) and two putative myristylation sites (aa 29-34 and 63-68) were found. To this respect, protein phosphorylation appears to be a necessary step in the intracellular signaling pathway that initiates the activation of sperm motility as it was shown by the rapid activation of live immotile sea urchin sperm produced achieved by increased phosphorylation on proteins of 32, 45, 130 and $500 \mathrm{kDa}$. These motility-related phosphoproteins were demonstrated to be associated with flagella and turned out to be dynein chains. In fact, cAMP-dependent phosphorylations of axonemal proteins have been reported to regulate the motility of sperm in salmonid fish, sea urchin, mussel, Ciona and mammals (Bracho, 1998). One example of proteins where the phosphorylation activates sperm motility is the $22 \mathrm{kDa}$ light chain of outer arm dynein in Tctex2 (LC2).

The bipartite nuclear localisation signal found through the amino acid sequence analysis suggests that the TSEP22 gene codes for a nuclear protein, finding corroborated by the "Reinhardt's method of cytoplasmic/nuclear discrimination", which predicts a $94.1 \%$ probability of a nuclear function. Nonetheless, the results of the subcellular localisation of the TSEP22-GFP fusion protein showed a clear cytoplasmic distribution, not nuclear. In spite of this, the possibility that TSEP22 could be transported to the nucleus cannot be excluded. Also, it is good to remind, that this subcellular localisation experiment was performed in cell types that are not germ cells since 15P1 corresponds to immortalized Sertoli cells and $3 \mathrm{~T} 3$ to cells coming from mouse fibroblasts. To this respect, several proteins have been observed to have a changing cellular localisation. For example the meichroacidin, which is a protein detected in pachytene spermatocytes, has both perichromosomal and cytoplasmic localisation (Tsuchida et al., 1998). Also, during interphase, lamin proteins localise exclusively in the perinuclear region, whereas in metaphase they become diffusely distributed throughout the cytoplasm (Kaneda et al., 1993). It was recently shown that both Drosophila polo and human polo-like kinase (Plk1) undergo cell cycle-changes in their localisation: they are cytoplasmic during interphase, but at metaphase they become associated with condensed chromosomes or 
spindles; after mitotic divisions, they again localize to the cytoplasm (Golsteyn et al., 1995). Mutations in polo kinase result in abnormal mitotic and meiotic divisions.

In this work the expression and genomic analyses of a testis-specific protein with a complex transcription pattern was performed. The testis-specific nature of TSEP2 2 and its probable post-translational control, give strong hints that this protein could play an important role in spermatogenesis, possibly focused in spermiogenesis. Further analysis of the TSEP22 protein remains to be done for the elucidation of its function in spermatogenesis. 


\section{APPENDIX}

\subsection{TSEP22 cDNA Clones Nucleotide Sequences}

\subsubsection{TSEP22 cDNA Sequence}

1 ggagagggtg ggaaatgaga gctcagccet agtcgaggga actgcaacct getgtactta

61 gagATGGACA GCAGGCAACA GCGCCCCCAG AGGAAGACGC TACAGTGGCA GCTTGCTCAA 121 GAGCAAAGAC AACAGTCACC CCCACAGGGG CTTGCCGTGG CCTCCAGCCA GCCAGACACC

181 AGGCGCCCAG GAAGTCGCTG GAACATCAGC ATCGATGAGC GCAGGCGGCT GGCCTTGCAG

241 AGGCGCCCAG GAAGTCGCTG GAACATCAGC ATCGATGAGC GCAGGCGGCT GGCCTTGCAG

301 CGTATGCAGG AGAGGACAGA CACAGCCAGG GCCCCATCCG GAGACCCGCT GGGCCTGCAC

361 CCTGAGGGCC AGCGAGCCGA AACTTCCCCA TCGACCCAGT CTGTCCCCAC CCCTCCCCTC

421 CAGGCCTGTG AgACTATGGC TGATCCCCTG CAGGACATCG CGCATGTGTT GgCCGAGCTG

481 ATGTCTGAgG GTGTAGAgAg AgATGTACTC ATTTCTCAGC CTCTAAGATC TACCGAGAAT

541 TTTAATGCCT TCCAGGACTT TTTGGCCCAG GACGCGCCTC TTTGGAAGGA TGAGAATTTT

601 GAGGCCCAGA CCTCAAGATG GCCTCACTCC TAAgaagcag ctttgctcag CCC

60

120

180

240

300

360

420

480

540

600

653

\subsubsection{F17 cDNA Sequence}

1

TAgGtAgAAg GCGgCCCCAg CAgGgCCtgC CAtCAtCtgC tTtAgGgAtC TGCCGTGgCA GCAGGAACCC TGCTCAGTTC CCTTCCTGCA CCTTGCCCCA CAGCCCTAGT CGAGGGAACT GCAACCTGCT GTACTTAGA ATGGACAGCA GGCAACAGCG CCCCCAGAGg AAGACGCTAC AGTGGCAGCT TGCTCAAGAG CAAAGACAAC AGTCACCCCC ACAGGGGCTT GCCGTGGCCT CCAGCCAGCC AGACACCAAG AGCAAGCCTC AGGACGACTT GCAGACCCAA GACTGGGTGT GTGAGCCTCA GGAACTCAGG CGCCCAGGAA GTCGCTGGAA CATCAGCATC GATGAGCGCA GGCGGCTGGC CTTGCAGCGT ATGCAGGAGA GGACAGACAC AGCCAGGGCC CCATCCGGAG ACCCGCTGGG CCTGCACCCT GAGGGCCAGC AGACCGAAAC CTCCCCATCG ACCCAGTCTG TCCCCACCCC TCCCCTCCAG GCCTGTGAGA CTATGGCTGA TCCCCTGCAG GACATCGCGC ATGTGTTGGC CGAGCTGATG TCTGAGgGTG TAGAGAGAGA TGTACTCATT TCTCAGCCTC TAAGATCTAC CGAGAATTCT AATGCCTTCC AGGACTTCTT GGCCCAGGAC GCGCCTCTTT GGAAGGATGA GAATTTTGA GCCCAGACCT CAAGATGGCC TCACTCCTAA GAAGCAGCTC TGCTCAGCCC AGTAAAAAAA AAAAAAA

60 120

\subsubsection{G101 cDNA Sequence}

1

GCGCTGAGCC TGGGCCTTGT GTGGTAGgGt TGTCCAAGAC AGGAGGAGGC CTATTGAgGG TGGGATCCTA GGACTGAAGA GCTTGTCAGG ACCGCAGAAC GAGCGCCCCC TGCGAGGAAA AGCAGACCAG GTGGTTCGCC CTAGTCGAGG GAACTGCAAC CTGCTGTACT TAGAGATGGA CAGCAGGCAA CAGCGCCCCC AGAGGAAGAC GCTACATGGG CAGCTTGCTC AAGAGCAAAG ACAACAGTCA CCCCCACAGG GGCTTGCCGT GGCCTCCAGC CAGCCAGACA CCAAGAGCAA GCCTCAGGAC GACTTGCAGA CCCAAGACTG GGTGTGTGAg CCTCAGGAAC TCAGGCGCCC AGGAAGTCGC TGGAACATCA GCATCGATGA GCGCAGGCGG CTGGCCTTGC AGCGTATGCA GGAGAGGACA GACACAGCCA GGGCCCCATC CGGAGACCCG CTGGGCCTGC ACCCTGAGGG CCAGCAGACC GAAACCTCCC CATCGACCCA GTCTGTCCCC ACCCCTCCCC TCCAGGCCTG TGAGACTATG GCTGATCCCC TGCAGGACAT CGCGCATGTG TTGGCCGAGC TGATGTCTGA GgGTGTAGA AGAGATGTAC TCATTTCTCA GCCTCTAAGA TCTACCGAGA ATTCTAATGC CTTCCAGGAC TTCTTGGCCC AGGACGCGCC TCTTTGGAAG GATGAGAATT TTGAGGCCCA GACCTCAAGA TGGCCTCACT CCTAAGAAGC AGCTCTGCTC AGCCCAGT

60 120 180 240 300 360 420 480 540 600 660 720 778

\subsubsection{P021 cDNA Sequence}

AtTAAGCCCC CCTCATCTGT CCCGGAgCCT AAgAgCCCTT CCCAGAgCCC TCTGgGCGAg CTCTGCATCC GCGTGGGAGC GGGTGACCCA ACTCCCACAT ACCTTCACTG CTGCCCTTAA CTGACTTCCA CAGTTCATAC CCACGGAGAG GGTGGGAAAT GAGAGCTCAG GTTGGCGCTG AgCCTGGgCC TTGTGTGGTA GgGTTGTCCA AgACAgGAgG AGgCCTATTG AgGgTGgGAT CCTAGGACTG AAgAGCTTGT CAGGACCGCA GAAGGAGCGC CCCCTGCGAg GAAAAGCAGA CCAGGTGGTT CGCCTAGTCG AGGGAACTGC AACCTGCTGT ACTTAGAGAT GGACAGCAGG CAACAGCGCC CCCAGAGGAA GACGCTACAG TGGCAGCTTG CTCAAGAGCA AAGACAACAG 


\section{Appendix}

421 TCACCCCCAC AGgGGCTTGC CGTGGCCTCC AgCCAGCCAg ACACCAAGA CAAGCCTCAG 481 GACGACTTGC AGACCCAAGA CTGGGTGTGT GAGCCTCAGG AACTCAGGCG CCCAGGAAGT

541 CGCTGGAACA TCAGCATCGA TGAGCGCAGg CGGCTGGCCT TGCAGCGTAT GCAGGAGAgG

601 ACAGACACAG CCAGGGCCCC ATCCGGAGAC CCGCTGGGCC TGCACCCTGA GGGCCAGCAG

661 ACCGAAACCT CCCCATCGAC CCAGTCTGTC CCCACCCCTC CCCTCCAGGC CTGTGAGACT

721 ATGGCTGATC CCCTGCAGGA CATCGCGCAT GTGTTGGCCG AGCTGATGTC TGAGGGTGTA

781 GAGAGAGATG TACTCATTTC TCAGCCTCTA AGATCTACCG AGAATTCTAA TGCCTTCCAG

841 GACTTCTTGG CCCAGgACGC GCCTCTTTGg AAgGATGAgA ATTTTGAgGC CCAGACCTCA

901 AGATGGCCTC ACTCCTAAGA AGCAGCTTTG CTCAGCCC

\subsubsection{O07 cDNA Sequence}

1 ACGCGATCCA GCTTTCTCAg GCTGGTGCTG AAgGTCCTAA GTCAGCCTCA CCAGCCAGCT

61 CTGTTTACCT GGACCCACAT GAGCGTTCAC AGGCCACACG ACCCTCCACT CCCTGTGCAG

121 ACCCTTCTGA GCCTGGGCTC ACCGGCTGAT CCATTGTCAA CCGGAGCTCA TTAAGCCCCC

181 CTCATCTGTC CCGGAGCCTA AGAGCCCTTC CCAGAGCCCT CTGGGCGAGC TCTGCATCCG

241 CGTGGGAGCG GGTGACCCAA CTCCCACATA CCTTCACTGC TGCCCTTAAC TGACTTCCAC

301 AgTTCATACC CACGGAGAGG GTGGGAAATG AGAGCTCAGg TTGGCGCTGA GCCTGGGCCT

361 TGTGTGGTAG GGTTGTCCAA GACAGGAGGA GGCCTATTGA GGGTGGGATC CTAGGACTGA

421 AgAGCTTGTC AgGACCGCAG AAgGAgCGCC CCCTGCGAGg AAAAGCAGAC CAGgtgGtTC

481 GCCTAGTCGA GGGAACTGCA ACCTGCTGTA CTTAGAGATg GACAGCAGGC AACAGCGCCC

541 CCAGAGGAAG ACGCTACAGT GGCAGCTTGC TCAAGAGCAA AGACAACAGT CACCCCCACA

601 GGGGCTTGCC GTGGCCTCCA GCCAGCCAGA CACCAAGAGC AAGCCTCAGG ACGACTTGCA

661 GACCCAAGAC TGgGTGTGTG AGCCTCAGGA ACTCAGGCGC CCAGGAAGTC GCTGGAACAT

721 CAGCATCGAT GAGCGCAGGC GGCTGGCCTT GCAGCGTATG CAGGAGAGGA CAGACACAGC

781 CAGGGCCCCA TCCGGAGACC CGCTGGGCCT GCAGCGTATG CAGGAGAGGA CAGACACAGC

841 CCCATCGACC CAGTCTGTCC CCACCCCTCC CCTCCAGGCC TGTGAGACTA TGGCTGATCC

901 CCTGCAGGAC ATCGCGCATG TGTTGgCCGA GCTGATGTCT GAGGGTGTAG AGAgAgAtgt

961 ACTCATTTCT CAGCCTCTAA GATCTACCGA GAATTCTAAT GCCTTCCAGG ACTTCTTGGC

1021 CCAGGACGCG CCTCTTTGGA AgGATGAgAA TTtTGAgGCC CAGACCTCAA GATGgCCTCA

1081 CTCCTAAGAA GCAGCTTTGC TCAGCCC

60

120

180

240

300

360

420

480

540

600

660

720

780

840

900

960

1020

1080

1107 


\section{SUMMARY}

In this work, the two murine genes Hook1 and TSEP22 were characterized at the molecular level. Both genes were expressed in male germ cells and the presence of the gene products of these two genes in elongated and late spermatids suggests that these genes play a role in the maturation and/or function of spermatozoa.

The Hook1 gene consists of 22 exons and the transcript as well as the protein, were detected in haploid male germ cells, namely round and elongated spermatids. The Hook1 gene product has been proposed to be involved in microtubule-dependent transport or in endocytosis processes. The gene was localized on chromosome 4C2-D5, where the azh mutation (abnormal spermatozoon head shape) was mapped. Analysis of the mouse Hook1 gene, both using DNA and RNA of azh/azh mutant revealed a deletion of exons 10 and 11 that results in a frame shift mutation. Furthermore, no Hook1 gene product could be detected in testicular protein extracts of the mutant mice using anti-Hook1 antibodies. The analysis of offsprings generated from heterozygous (+/azh) mice, proved that the mutant phenotype segregate with the deletion. These results strongly indicate that the loss of Hook1 function results in an azh/azh mutant phenotype.

The murine TSEP22 gene consists of three exons and was localized to mouse chromosome 12. TSEP22 has several transcripts that were detected in pachytene spermatocytes and spermatids. At cDNA level, variable 5'UTRs were identified, which could be involved in translational control. This possibility arises because the TSEP22 protein was first detected at day 18 of postnatal testicular development, three days after the TSEP22 transcripts appear. The TSEP22 protein has been located to the sperm midpiece and display several putative phosphorylation sites that can influence posttranslational regulation. Phosphorylation is known to be involved in regulation of sperm flagella motility, and further analysis of this gene is needed to unveal what function it has in spermatogenesis. 


\section{REFERENCES}

Agianian B, Leonard K, Bonte E, Van der Zandt H, Becker PB, Tucker PA. (1999). The glutamine-rich domain of the Drosophila GAGA factor is necessary for amyloid fibre formation in vitro, but not for chromatin remodelling. J Mol Biol. 285(2):527-44.

Akutsu H, Tres LL, Tateno H, Yanagimachi R, Kierszenbaum AL. (2001). Offspring from normal mouse oocytes injected with sperm heads from the azh/azh mouse display more severe sperm tail abnormalities than the original mutant. Biol Reprod. 64(1):249-56.

Alberts B, Bray D, Lewis J, Raff M, Roberts K, Watson JD. (1994). Molecular Biology of the Cell. Third Edition. New York: Garland Publishing. pp: 1011-34.

Allen LA, Aderem A. (1995). Protein kinase C regulates MARCKS cycling between the plasma membrane and lysosomes in fibroblasts. EMBO J. 14(6):1109-20.

Altschul SF, Gish W, Miller W, Myers EW, Lipman DJ. (1990). Basic local alignment search tool. J. Mol. Biol. 215:403-10.

Altschul SF, Madden TL, Schäffer AA, Zhang J, Zhang Z, Miller W, Lipman DJ. (1997). Gapped BLAST and PSI-BLAST: a new generation of protein database search programs. Nucleic Acids Res. 25:3389-3402.

Ashman JB, Hall ES, Eveleth J, Boekelheide K. (1992). Tau, the neuronal heat-stable microtubule-associated protein, is also present in the cross-linked microtubule network of the testicular spermatid manchette. Biol Reprod. 46(1):120-9.

Bacetti B. (1970). Comparative spermatology. Academic Press, New York. 
Baker HWG. (2000). Management of male infertility. Baillière's Best Practice and Research in Clinical Endocrinology and Metabolism. 14:409-422.

Bennet WI, Gall AM, Southard JL, Sidman RL (1971). Abnormal spermiogenesis in quaking, a myelin deficient mutant mouse. Biol. Reprod. 5:30-58.

Birnboim HC, Doly J. (1979). A rapid alkaline extraction procedure for screening recombinant plasmid DNA. Nucleic Acids Res. Nov 24;7(6):1513-23.

Bracho GE, Fritch JJ, Tash JS. (1998). Identification of flagellar proteins that initiate the activation of sperm motility in vivo. Biochem Biophys Res Commun. 242(1):2317.

Bryan JH. Spermatogenesis revisited. III. (1977a). The course of spermatogenesis in a male-sterile pink-eyed mutant type in the mouse. Cell Tissue Res. May 16;180(2):173-86.

Bryan JH. (1977b). Spermatogenesis revisited. IV. Abnormal spermiogenesis in mice homozygous for another male-sterility-inducing mutation, hpy (hydrocephalicpolydactyl). Cell Tissue Res. May 16;180(2):187-201.Check JH, Katsoff D, Check ML. (2001) Some semen abnormalities may cause infertility by impairing implantation rather than fertilization. Medical Hypotheses. 56:653-657.

Cant K, Knowles BA, Mooseker MS, Cooley L. (1994). Drosophila singed, a fascin homolog, is required for actin bundle formation during oogenesis and bristle extension. J Cell Biol. 125(2):369-80.

Clermont Y, Oko R, Hermo L. (1993). Cell biology of mammalian spermatogenesis. In: Desjardins C, Ewing LL, editors. Cell and molecular biology of the testis. New York: oxford University Press. pp:332-376. 
Clermont Y. (1954). Cycle de l'épithélium seminal et mode de renouvellement des spermiogonies chez le hamster. Rev. Canad. Biol. 13:208-45.

Cobb J, Cargile B, Handel MA. (1999). Acquisition of competence to condense metaphase I chromosomes during spermatogenesis. Dev Biol. 205(1):49-64.

Cole A, Meistrich ML, Cherry LM, Trostle-Weige PK. (1988). Nuclear and manchette development in spermatids of normal and azh/azh mutant mice. Biol Reprod. 38(2):385-401.

Colgan DF, Manley JL. (1997). Mechanism and regulation of mRNA polyadenylation. Genes Dev. 11(21):2755-66.

Cormand B, Avela K, Pihko H, Santavuori P, Talim B, Topaloglu H, de la Chapelle A, Lehesjoki AE. (1999). Assignment of the muscle-eye-brain disease gene to 1p32p34 by linkage analysis and homozygosity mapping. Am J Hum Genet. 64(1):126-35.

Crawford J, Ianzano L, Savino M, Whitmore S, Cleton-Jansen AM, Settasatian C, d'apolito M, Seshadri R, Pronk JC, Auerbach AD, Verlander PC, Mathew CG, Tipping AJ, Doggett NA, Zelante L, Callen DF, Savoia A. (1999). The PISSLRE gene: structure, exon skipping, and exclusion as tumor suppressor in breast cancer. Genomics.56(1):90-7.

Chevray PM, Nathans D. (1992). Protein interaction cloning in yeast: identification of mammalian proteins that react with the leucine zipper of Jun. Proc Natl Acad Sci U S A. 89(13):5789-93.

Dooher GB, Bennett D. (1974). Abnormal microtubular systems in mouse spermatids associated with a mutant gene at the T-locus. J Embryol Exp Morphol. 32(3):74961. 
Dooher GB, Bennett D. (1977). A simple technique for preparing easy to read, permanent cytotoxicity tests on mouse spermatozoa. Transplantation. 23(4):381-3.

Edwalds-Gilbert G, Veraldi KL, Milcarek C. (1997). Alternative poly(A) site selection in complex transcription units: means to an end? Nucleic Acids Res. 25(13):254761.

Ensembl Trace Server. (http://www.ensembl.org.).

Expasy tools. (http://www.expasy.ch/tools),

Fawcett DW. (1970). A comparative view of sperm ultrastructure. Biol. Reprod. 2.(Suppl. 2):90-127.

Fawcett DW, Anderson WA, Phillips DM. (1971). Morphogenetic factors influencing the shape of the sperm head. Dev. Biol. 26:220-251.

Fawcett DW. (1975). The mammalian spermatozoon. Dev Biol. 44(2):394-436.

Fitzgerald M, Shenk T. (1981). The sequence 5'-AAUAAA-3'forms parts of the recognition site for polyadenylation of late SV40 mRNAs. Cell. (1):251-60

Gene Expression Database (GXD), Mouse Genome Informatics Web Site, The Jackson Laboratory, Bar Harbor, Maine. World Wide Web (URL: http://www.informatics.jax.org/). (Sep, 2001).

Gilbert, SF. (1997). Developmental Biology. Fifth Edition. Sunderland, MA. Sinauer. pp 585-614. 
Golsteyn RM, Mundt KE, Fry AM, Nigg EA. (1995). Cell cycle regulation of the activity and subcellular localization of Plk1, a human protein kinase implicated in mitotic spindle function. J Cell Biol. 129(6):1617-28.

Gong XD, Li JC, Cheung KH, Leung GP, Chew SB, Wong PY. (2001). Expression of the cystic fibrosis transmembrane conductance regulator in rat spermatids: implication for the site of action of antispermatogenic agents. Mol Hum Reprod. 7(8):705-13.

Gruenberg J, Howell KE. (1989). Membrane traffic in endocytosis: insights from cellfree assays. Annu Rev Cell Biol.;5:453-81.

Hake LE, Hecht NB. (1993). Utilization of an alternative transcription initiation site of somatic cytochrome $\mathrm{c}$ in the mouse produces a testis-specific cytochrome $\mathrm{c}$ mRNA. J Biol Chem. 268(7):4788-97.

Hall ES, Eveleth J, Jiang C, Redenbach DM, Boekelheide K. (1992). Distribution of the microtubule-dependent motors cytoplasmic dynein and kinesin in rat testis. Biol Reprod. 46(5):817-28.

Hara, Y, Rovescalli AC, Kim Y, Nirenberg M. (1992). Structure and evolution of four POU domain genes expressed in mouse brain. Proc Natl Acad Sci USA. 89(8):3280-4.

Higashinakagawa, T., \& Fujimoto, H. (1993). A novel murine zinc finger gene mapped within the tw18 deletion region expresses in germ cells and embryonic nervous system. Dev Biol. 155:409422.

Hugenholtz AP, Eng VWS, Bruce WR. (1984). Mouse News Letter. 71:34-35. 
Iida H, Doiguchi M, Yamashita H, Sugimachi S, Ichinose J, Mori T, Shibata Y. (2001). Spermatid-specific expression of Iba1, an ionized calcium binding adapter molecule-1, in rat testis. Biol Reprod. 64(4):1138-46.

Kahraman S, Akarsu C, Cengiz G, Dirican K, Sozen E, Can B, Guven C, Vanderzwalmen P. (1999). Fertility of ejaculated and testicular megalohead spermatozoa with intracytoplasmic sperm injection. Hum Reprod. 14(3):726-30.

Kamal A, Mansour R, Fahmy I, Serour G, Rhodes C, Aboulghar M. (1999). Easily decapitated spermatozoa defect: a possible cause of unexplained infertility. Hum Reprod. 14(11):2791-5.

Kaneda Y, Kinoshita K, Sato M, Tanaka K, Kaneda Y. (1993). The analysis of 40 kDa nuclear protein, p40, in interphase cells and mitotic cells. J Cell Sci. 106 ( Pt 3):741-8.

Kim Y, Glatt H, Xie W, Sinnett D, Lalande (1997). M. Human gamma-aminobutyric acid-type A receptor alpha5 subunit gene (GABRA5): characterization and structural organization of the 5 ' flanking region. Genomics. 42(3):378-87.

Kozak M. (1987). At least six nucleotides preceding the AUG initiator codon enhance translation in mammalian cells. J Mol Biol. 196(4):947-950.

Kramer H, Phistry M. (1996). Mutations in the Drosophila hook gene inhibit endocytosis of the boss transmembrane ligand into multivesicular bodies. J Cell Biol. 133(6):1205-15.

Kramer H, Phistry M. (1999). Genetic analysis of hook, a gene required for endocytic trafficking in Drosophila. Genetics. 151(2):675-84. 
Kremling H, Nayernia K, Nieter S, Bunkowski S, Engel W. (1995). DNA-protein binding studies in the $5^{\prime}$ flanking region of rat proacrosin gene which is transcribed in diploid germ cells. Biol Chem Hoppe Seyler. 376(3):187-93.

Lalli M, Clermont Y. (1981). Structural changes of the head components of the rat spermatid during late spermiogenesis. Am J Anat. 160(4):419-34.

Leblond CP and Clermont Y. (1952). Spermiogenesis of rat, hamster and guinea pig as revealed by the "periodic acid-fuchsin sulfurous acid" technique. Am. J. Anat. 90:167-215.

Lippincott-Schwartz J. (1998). Cytoskeletal proteins and Golgi dynamics. Curr Opin Cell Biol. 10(1):52-9.

Lupas A, Van Dyke M, Stock J. (1991). Predicting coiled coils from protein sequences. Science. 252(5010):1162-4.

MacKinnon EA, Abraham PJ, Svatek A. (1973). Long link induction between the microtubules of the manchette in intermediate stages of spermiogenesis. $Z$. Zellforsch. 136:447-60.

Manley JL. (1995). A complex protein assembly catalyzes polyadenylation of mRNA precursors. Curr Opin Genet Dev. 5(2):222-8.

Meiron M, Anunu R, Scheinman EJ, Hashmueli S, Levi BZ. (2001). New isoforms of VEGF are translated from alternative initiation CUG codons located in its 5'UTR. Biochem Biophys Res Commun. 282(4):1053-60.

Meistrich ML, Trostle-Weige PK, Yick J, Ramagli LS, Rodriguez LV, Slaughter GR, Hake L, Hecht NB, Balhorn R. (1988). Biochemical studies of azh mutant mice with abnormal sperm heads. In:M Pavinen, I Huhtaniemi, Pelliniemi LJ 
(eds):"Development and Function of the Reproductive Organs". Rome: AresSerono Symposia, pp 231-5.

Meistrich ML, Trostle-Weige PK, Russell LD, (1990). Abnormal manchette development in spermatids of azh/azh mutant mice. Am J Anat. 188(1):74-86.

Meistrich ML, Trostle-Weige PK, Womack JE. (1992). Mapping of the azh locus to mouse chromosome 4. J Hered. 83(1):56-61.

Meistrich ML. (1993). Nuclear morphogenesis during spermiogenesis. In: de Kretser D, editor. Molecular biology of the male reproductive system. New York: Academic Press. Pp57-97.

Meistrich ML, Kasai K, Olds-Clarke P, MacGregor GR, Berkowitz AD, Tung KS. (1994). Deficiency in fertilization by morphologically abnormal sperm produced by azh mutant mice. Mol Reprod Dev. 37(1):69-77.

Miranda-Vizuete A, Ljung J, Damdimopoulos AE, Gustafsson JA, Oko R, Pelto-Huikko M, Spyrou G. (2001). Characterization of Sptrx, a novel member of the thioredoxin family specifically expressed in human spermatozoa. J Biol Chem. 276(34):31567-74.

Mochida K., Tres LL, Kierszenbaum AL. (1998). Isolation of the Rat Spermatid Manchette and Its Perinuclear Ring. Dev Biol. 200:46-56.

Mochida K, Tres LL, Kierszenbaum AL. (1999). Structural and biochemical features of fractionated spermatid manchettes and sperm axonemes of the azh/azh mutant mouse. Mol Reprod Dev. 52(4):434-44. 
Narayanan R, Kramer H, Ramaswami M. (2000). Drosophila endosomal proteins hook and deep orange regulate synapse size but not synaptic vesicle recycling. J NeurobiolNov 5;45(2):105-19.

Neesen J. (1999). Zur Genetik funktioneller und struktureller Spermiendefekte. Reproduktionsmedizin. 15:55-64.

Nielsen E, Christoforidis S, Uttenweiler-Joseph S, Miaczynska M, Dewitte F, Wilm M, Hoflack B, Zerial M. (2000). Rabenosyn-5, a novel Rab5 effector, is complexed with hVPS45 and recruited to endosomes through a FYVE finger domain. J Cell Biol. 151(3):601-1.

Noce, T., Fujiwara, Y., Ito, M., Takeuchi, T., Hashimoto, N., Yamanouchi, M., Ogawa K, Mohri T, Mohri H. (1977). Identification of dynein as the outer arms of sea urchin sperm axonemes. Proc Natl Acad Sci U S A. 74(11):5006-10.

Online Mendelian Inheritance in Man, OMIM (TM). Johns Hopkins University, Baltimore, MD. Immotile Cilia Syndrome. MIM Number: 242650: 1/3/2001: http://www.ncbi.nlm.nih.gov/omim/

Online Mendelian Inheritance in Man, OMIM (TM). Johns Hopkins University, Baltimore, MD. Muscle, eye, brain disease. MIM Number: 253280: 26/7/1999: http: //www.ncbi.nlm.nih.gov/omim/

Øyen O, Myklebust F, Scott JD, Cadd GG, McKnight GS, Hansson V, Jahnsen T. (1990). Subunits of cyclic adenosine 3', 5'-monophosphate-dependent protein kinase show differential and distinct expression patterns during germ cell differentiation: alternative polyadenylation in germ cells gives rise to unique smaller-sized mRNA species. Biol Reprod. 43(1):46-54. 
Parysek LM, Asnes CF, Olmsted JB. (1984). The cytological distribution of microtubuleassociated protein 4 (MAP-4). J. Cell. Biol. 99:1309-15.

Pazour GJ, Wilkerson CG, Witman GB. (1998). A dynein light chain is essential for the retrograde particle movement of intraflagellar transport (IFT). J Cell Biol. May 18;141(4):979-92.

Phillips DM. (1977). Mitochondrial disposition in mammalian spermatozoa. J Ultrastruct Res. (2):144-54.

Pinto M, Lobe CG. (1996). Products of the grg (Groucho-related gene) family can dimerize through the amino-terminal Q domain. J Biol Chem. 271(51):33026-31.

Proudfoot NJ, Brownlee GG. (1976). 3' non-coding region sequences in eukaryotic messenger RNA. Nature. 263(5574):211-4.

Raitta C, Lamminen M, Santavuori P, Leisti J. (1978). Ophthalmological findings in a new syndrome with muscle, eye and brain involvement. Acta Ophthalmol (Copenh). 56(3):465-72. Rattner JB and Brinkley BR. (1972). Ultrastructure of mammalian spermiogenesis. III. The organization and morphogenesis of the manchette during rodent spermatogenesis. J. Ultrastruc. Res. 43:438-44.

Ravnik SE, Wolgemuth DJ. (1996). The developmentally restricted pattern of expression in the male germ line of a murine cyclin A, cyclin A2, suggests roles in both mitotic and meiotic cell cycles. Dev Biol. 173(1):69-78.

Russell LD, Ettlin RA, Sihna Hikim AP, Clegg ED. (1990). Histopathological Evaluation of the Testis. Cache River Press, Clearwater, FL:

Russell LD, Russell JA, MacGregor GR, Meistrich ML. (1991). Linkage of manchette microtubules to the nuclear envelope and observations of the role of the 
manchette in nuclear shaping during spermiogenesis in rodents. Am J Anat. Oct;192(2):97-120.

Russell LD, Saxena NK, Turner TT. (1989). Cytoskeletal involvement in spermiation and sperm transport. Tissue Cell.;21(3):361-79.

Said K, Jaqart T, Montgelard C, Sonjaya H, Helal AN, Britton-Davidian J, (1986). Robertsonian house mouse population in Tunisia: a karyological and biochemical study. Genetica. 68:pp. 151-6.

Saiki RK, Gelfand DH, Stoffel S, Scharf SJ, Higuchi R, Horn GT, Mullis KB, Erlich HA. (1988). Primer-directed enzymatic amplification of DNA with a thermostable DNA polymerase. Science. 239(4839):487-91.

Sambrook J, Fritsch EF, Maniatis T. (1989). Molecular cloning: a laboratory manual. Cold Spring Harbor. New York: Cold Spring Harbor Laboratory Press.

Sanger F, Nicklen S, Coulson AR. (1977). DNA sequencing with chain-terminating inhibitors. Proc Natl Acad Sci U S A. Dec;74(12):5463-7.

Santavuori P, Somer H, Sainio K, Rapola J, Kruus S, Nikitin T, Ketonen L, Leisti J. (1989). Muscle-eye-brain disease (MEB). Brain Dev.;11(3):147-53.

Shinyoji C, Higuchi H, Yoshimura M. Katayama E, Yanagida T. (1998). Dynein arms are oscillating force generators. Nature. 393:711-14.

Standiford DM, Davis MB, Miedema K, Franzini-Armstrong C, Emerson CP Jr. (1997). Myosin rod protein: a novel thick filament component of Drosophila muscle. J Mol Biol. 265(1):40-55. 
Sunio A, Metcalf AB, Kramer H. (1999). Genetic dissection of endocytic trafficking in Drosophila using a horseradish peroxidase-bride of sevenless chimera: hook is required for normal maturation of multivesicular endosomes. Mol Biol Cell. 10(4):847-59.

Tsuchida J, Nishina Y, Wakabayashi N, Nozaki M, Sakai Y, Nishimune Y. (1998). Molecular cloning and characterization of meichroacidin (male meiotic metaphase chromosome-associated acidic protein. Dev Biol. 197(1):67-76.

Toshimori K, Yoshinaga K, Tanii I, Wakayama T, Saxena DK, Ohoka T. (2001). Protein expression and cell organelle behavior in spermatogenic cells. Kaibogaku Zasshi. 76(3):267-279.

Vale RD, Reese TS, Sheetz MP. (1985a). Identification of a novel force-generating protein, kinesin, involved in microtubule-based motility. Cell. 42(1):39-50.

Vale RD, Schnapp BJ, Reese TS, Sheetz MP. (1985b). Organelle, bead, and microtubule translocations promoted by soluble factors from the squid giant axon. Cell. 40(3):559-69.

Walenta JH, Didier AJ, Liu X, Kramer H. (2001). The Golgi-associated hook3 protein is a member of a novel family of microtubule-binding proteins. J Cell Biol. 5;152(5):923-34.

Wallace AM, Dass B, Ravnik SE, Tonk, Jenkins N.A., Gilbert D.J., Copeland N.G. (1999). Two distinct forms of the 64,000 M r protein of the cleavage stimulation factor are expressed in mouse male germ cells. Proc Natl Acad Sci U S A. 96(12):6763-8.

Wilusz J, Shenk T. (1988). A 64 kd nuclear protein binds to RNA segments that include the AAUAAA polyadenilation motif. Cell. 52(2):221-8. 
Yoshida T, Ioshii SO, Imanaka-Yoshida K, Izutsu K. (1994). Association of cytoplasmic dynein with manchette microtubules and spermatid nuclear envelope during spermiogenesis in rats. J Cell Sci. 107 (Pt 3):625-33. 


\section{CURRICULUM VITAE}

Name:

Vorname:

Addresse:

Geburtsdatum:

Familienstand:

Staatsangehörigkeit:

1988:

09.1988:

07 1992:

11 1992:

09 1994-07 1997:

07 1997-06 1999

03 2000-09 2001
Mendoza-Lujambio

Irene

Priv. Margarita Salazar 2262130 Cuernavaca, México

16.11.1969

verheiratet

Mexikanisch

allgemeine Hochschulreife

Beginn des Studiums der Biologie an der Autonomen Universität Guadalajara

Vordiplom im Fach Biologie

Preis als "Die Beste Studentin in Mexiko" im Fach Biologie Anfertigung des Master's Degree im Fach Humangenetik, Thema:

"Detektion von Q188R und N314D Mutationen im Galaktose1-Phosphat-Uridyltransferase Gen in Galaktosä-mie Patienten und Personen mit Duarte und Los Angeles Varianten". DAAD Stipendiatin, Anfertigung einer Doktorarbeit in Deutschland am Institut für Humangenetik der Universität Göttingen,

Thema: "Molekular Charakterisierung der Hook1 und TSEP22 Gene, die in Männlicher Kernzellen exprimiert sind"- Molecular Characterization of the Male Germ Cell Expressed Genes Hook1 and TSEP22".

Wissenschaftliche Mitarbeiterin an der Universität Göttingen (Halbestelle).

Cuernavaca, den 25.10.2003

Irene Mendoza-Lujambio 


\section{Acknowledgements}

\section{ACKNOWLEDGEMENTS}

I want to thank deeply Prof. Dr. W. Engel for giving me the great chance in my life to perform the Ph. D. studies here in the Institut für Humangenetik and having me supported when I needed the most. His help has been very important for me.

I thank Prof. Dr. S. Hoyer-Fender for having accepted to be my Co-referent in this work. I thank the exception Prof. Hoyer-Fender did to make this possible.

I thank sincerely and deeply Dr. J. Neesen for giving me the chance to learn with him and make the Ph. D. work in the laboratory under his charge. Also, his financial support was essential for me to finish and make this work possible. I will always be thankful for his help and understanding about all the events that happened during this time.

I thank DAAD, because its financial support make possible for me to come to accomplish this Ph. D. work.

I thank CONACYT for the financial support during this time to do this Ph. D. work.

I thank Dr. C. Dixkens and Prof. A. Mainhardt for their technical support in some experiments performed in this work.

I thank my co-workers in laboratory 114 that helped me through this work, especially Mr. G. Batjargal and Frau N. Dörwald as well as Mr. C. Müller from laboratory 107.

I thank my husband, Juan Carlos Soriano, because without his help and support, the completion of this work would not have been possible at all. Thank you for everything.

I thank my parents, Luis Mendoza and Aurora Lujambio as well as all my brothers and sister (Luis Angel, Rocío, Víctor Hugo, José Antonio) for their neverending support and help, which has been always very important for me.

At last, but not least, I thank deep from my heart to God. He is my shepperd and I will always thank his help and the strength and gifts he has given me. Sometimes it seemed impossible to finish this Ph. D. work and undoubtedly he helped me through it.

I dedicate this work to the memory of my parents, Luis and Aurora, and to my children, Frida Kathrin and Sven Alexander, who are evrything to me. 